
$B / C \rightarrow$ 


\title{
A PHILOSOPHY OF POLITICAL MYTH
}

\author{
By

\section{Chiara BOTTICI}

Thesis submitted for assessment with A view to obtaining the Degree of Doctor of the European University Institute

Jury Members:

Prof. Peter Wagner, EUI (Supervisor)

Prof. Furio Cerutti (University of Florence) (External Co-Supervisor) Prof. Alessandro Pizzomo (Former EUI)

Prof. Bo Stråth (EUI) 
320.014

HCIT

$\therefore \quad \therefore \quad$ 
To B.

for the myths he gave me 


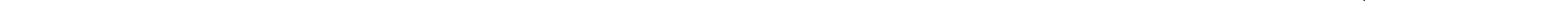




\section{Ackwnowledgements}

This work is the result of many years of study and discussions spent in different European universities. Apart from the fundamental support of the European University Institute and of all the people working there, I have also benefited from research and discussions held at the Humboldt Universität Berlin, the Frei Universität Berlin, the Eberhard Karls Universität Tübingen, the London School of Economics and Political Science, the University of Pisa and the University of Florence. I am particularly thankful to the staff of the EUI's Interlibrary Loans Service, for their patience and efficiency.

The people who contributed to this work over all these years can hardly be enumerated. In particular, I wish to thank my supervisor Peter Wagner, without whose constant support and encouragement I could not have accomplished this enterprise. I also wish to thank Furio Cerutti, my second supervisor, whose criticisms led me to strengthen, and thus improve, my argument.

Various people have also contributed with their specific competences: a special thanks to Benoît Challand (EUI), for his fundamental help with Greek philology, to Rolf Geiger (Eberhard Karls Universität Tübingen), who lent to me his competencies on Greek philosophy, to Irene Becci and the other participants of the "EUI Bible working group" for stimulating discussions, to Elise Marrou (Paris 1-Sorbonne) for her comments on Wittgenstein, and to John Michael Krois (Humboldt Universität Berlin), who generously shared with me his expertise on Cassirer's philosophy. I am also particularly grateful to Tommaso Codignola, Thomas Hippler, Tamara Stümpflen and the others participants of the "EUI Spinoza working group", without whose help Spinoza's Ethics would have been unaccessible. I am indebted to Alessandro Pizzomo and Camil Ungureanu for many philosophical symposia. For reading and commenting on various parts of the text, I also wish to thank Luca Baccelli (University of Pisa), John Hutchinson (LSE), Gianfranco Poggi (University of Trento), Thomas Pogge (Columbia University), Anthony D. Smith (LSE) and the participants of the "Seminario di Filosofia Politica" (Univeristy of Florence), in particular Daniela Belliti, Dimitri D'Andrea, Elena Pulcini and Monica Toraldo di Francia. A special thanks to Alana Lentin (University of Oxford) for reading the whole text and for sharing her ideas with me. 
Finally, I wish to thank Jeremie Barthas, Filippo Benfante, Hakim Boulhares, Jean Terrier and all the other participants of the Collettivo IUE with whom I discussed my ideas on many occasions.

\section{Note}

The following work is based on a variety of texts. The intent, in quoting them, has never been to fully reconstruct their content, but rather to extract key arguments for the discussion. I apologise if some authos may appear to have been mutilate.

Quotations, if not otherwise indicated in the bibliography, were taken from their English translations. When these latter were not available, I translated them myself and indicated it in the text. In a few cases, when to translate was, for various reasons, inopportune, $I$ left the quotations in their original language.

References to ancient classical texts are made unsing the system "title plus reference". For example,

(Poetics, 1447a 20) indicates passage 1447a 20 of Aristotle's Poetics.

(Resp. 519c.ff) indicates passage 519c and following of Plato's Republics

More recent texts, instead, are quoted using the system "author plus year of the first edition plus chapter (when preceded by a comma) or page number (when preceded by a colon)". For instance,

(Nietzsche 1887, I, 6) indicates Nietzsche's Genealogy of Morals, part I, section 6

(Flood 1996:147) indicates instead page 147 of Flood's Political Myth.

Finally, the text is most often feminised, a part from the few cases when this might have distorted an author's thinking or attitude. 


\section{TABLE OF CONTENTS}

INTRODUCTION

I. A GENEALOGY OF MYTH 20

1. MYTHOS AND LOGOS 22

2. THE BIBLOS AND THE DIALECTIC OF THE SACRED LOGOS

3. SCIENTIFIC RATIONALITY AND THE DIALECTIC OF THE ENLIGHTENMENT $\quad 64$

II. THE NEED FOR MYTH 82

4. MYTH AND MEANING

5. APPROACHING MYTH 99

6. NAMING THE UNKNOWN, GROUNDING SIGNIFICANCE 115

III. POLITICAL MYTH 130

7. MYTH AND THE CRITIQUE OF POLITICAL REASON 132

8. CLASSICAL THEORIES OF POLITICAL MYTH 152

9. POLITICAL MYTH, IDEOLOGY AND UTOPIA 179

IV. MYTH AND POLITICAL IDENTITY 203

10. MYTH, HISTORICAL NARRATIVES AND THE SOCIAL IMAGINARY 205

11. MYTH AND IDENTITY 227

12. POLITICAL MYTHS TODAY:THE EXTRAODINARY AND THE BANAL 246

$\begin{array}{ll}\text { BIBLIOGRAPHY } & 260\end{array}$ 


\section{INTRODUCTION}

After reading John Rawls' Theory of Justice or Habermas' Faktizität und Geltung, perhaps the two major books in political philosophy of the last fifty years, one could emerge with the impression that politics is an activity always potentially involving rational individuals meeting other rational individuals. In whatever ways rationality is conceived, as either rationality in respect to ends and values or as communicative rationality, the image of politics resulting from these works is that of an activity which can and should be guided by rational procedures.

When one looks at the everyday activity that goes under the heading of "politics", one is confronted with quite a different picture. People involved in this activity are not so easily persuaded to adopt rational procedures of communication and decision. Quite often people seem rather to act on the basis of a-rational elements, some other kinds of powerful symbols and images of the world, which are not taken into account by a purely rationalist approach to politics.

On the other hand, there are some events, for instance when people show a willingness to sacrifice their own lives that openly clashes with a rationalist image. The twentieth century, with the rise of totalitarianism and its two world wars contains countless examples. All the same, while the grandiose parades of totalitarian regimes exhibited the power of a-rational elements such as myths and symbols in a patent way, there seems to be some reasons to suspect that they still operate. Despite the fact that their presence is not always as conspicuous, they could still be there exercising their power in a more subtle way.

Scholars of different proveniences have long since recognised the important political role played by a-rational elements. Sociologists, historians and anthropologists, each in their own way, have devoted an important part of their work to the analysis of these kinds of phenomena. Anthropologists have always been dealing with such issues. As external observers catapulted into remote regions of the world they were perhaps in 
the best position to do so: their foreignness to the "primitives" made the myths and symbols of these peoples conspicuous to their eyes. Furthermore, in the study of archaic and traditional societies, the presence of such phenomena seemed to be the obvious consequence of the fact that politics could hardly be separated from religion in these societies. $^{1}$

Historians also have long since dealt with such phenomena, at least from $M$. Bloch's Le rois thaumaturges (Bloch 1924) and E. Kantorowicz's seminal work on the medieval political theology (Kantorowicz 1957). In particular these two works, by starting from the very observation that rulers share some properties with gods, opened the path for a new series of study on the mythical and symbolic dimension of power.

But all these studies were still confined to traditional or archaic societies where the influence of myths and symbols could still be attributed to the proximity between politics and religion that characterises these societies. Sociology has also been dealing with these topics for a long time: one just has to think of Durkheim's sociology or Weber's works on charisma. ${ }^{2}$ However, whilst Weber was aware of the possibility of new prophets, ${ }^{3}$ by moving from his prediction of an iron cage, one could assume that modern politics, with its increasing rationalisation and bureaucratisation, had become immune to their influence: in a bureaucratic iron cage there seems to be prima facie little space for myths and symbols. As far as politics is seen as prey of "specialists without spirits" (Weber 1905), one could well suspect that there is no more need for myth and symbols.

However, relatively recently, a new series of studies focusing on the mobilising power of myth and symbols in modern politics has emerged. The rise of identity politics and the revival of nationalism of the last decades have perhaps rendered manifest that, to paraphrase Geertz, the extraordinary has not gone out of modern politics, however much of the banal may have entered it. On the other hand, the emphasis on constructivism and the linguistic turn has given rise to a new interest in the symbolic dimension of social phenomena. As a consequence, titles such as "The invention of $x$ " or "The symbolic

\footnotetext{
'See for instance the classical Malinowski 1948 or, more recently, Geertz 1983. Both Geertz and Malinowski deal however with myths under the general category of political symbolism rather than on political myth specifically.

${ }^{2}$ On this point, see in particular Eisenstadt's collection of Weber's works on charisma and institution building (Weber 1969). However, as we will see, all these works were not dealing with the specific notion of political myth.

Most famously see the end of Die Protestantishe Ethik und der Geist des Kapitalismus (Weber 1905).
} 
construction of $y$ and $z$ are quite common today. ${ }^{4}$ The result of this new emphasis is indeed a striking number of publications containing the word "myth" and "symbols".

The exponential number of publications on this topic would suggest the existence of a refined and consolidated theoretical framework for their use. On the contrary, it seems as if there is not yet one. In particular, whereas there is a vast theoretical literature generally dealing with the symbolic dimension of power, the different forms of political symbolism are rarely dealt with separately. To deal with these phenomana under the common headings such as "the extraordinary" or "the symbolism of power" (Geertz 1983) can be misleading, because it can come to suggest that all that is not rational is symbolic or extraordinary.

Indeed, headings such as "The Symbolic Uses of Politics" (Edelman 1976) or "The Construction of Society" (Cohen 1985) quite often end up unifying very different phenomena - in particular, symbolism, generally understood, and myth. The problem, however, is that myths and symbols do not coincide. Despite the fact that myth operates with symbols, the two concepts of myth and symbol must be kept and treated separated: to conflate the two would mean to lose the specificity of myth. Indeed if myths operate through symbols, not all symbols are myths: the sequence of letters of a mathematical equation is also a symbol, but nobody - or only very few - would argue that it is a myth. To put it in Cassirer's words, symbols, in this sense, are the transcendental conditions of the human mind: myth, science, language itself, are all "symbolic functions", i.e. functions of the human mind through which only the multiplicity of experience can be grasped and communicated (Cassirer 1925).

It is precisely the conflation between these concepts that has generated most of the confusion surrounding this topic. In turn, this has also generated a great reluctance to use the concept of myth at all - particularly as related to the realm of politics. Why make recourse to such a concept as cumbersome such as myth, and not recur instead to other concepts such as "tales", "narratives" or "legends"?

Much of this work will be devoted to showing that to make recourse to such substitutes is neither possible nor necessary. It is not possible, because all of these alternatives are inadequate for conveying the semantic complexities of the concept of myth. Indeed, the word myth has been used - and abused - in so many different and

\footnotetext{
${ }^{4}$ See in particular "The Invention of Tradition" by the historians Hobsbawm and Ranger (Hobsbawm and Ranger 1983) and "The Symbolic Construction of Community" by the anthropologist A.P. Cohen's (Cohen 1985).
} 
various ways. In front of the varieties of the conceptions of myth, more that fifty years ago E. Cassirer recalled the scene of the witch's kitchen in Goethe's Faust: Faust, waiting for the drink by virtue of which he shall regain his youth, stands in front of an enchanted glass and has the wonderful vision of a woman of supernatural beauty. Faust is enraptured and spellbound, but Mephisto, standing at his side, scoffs at his enthusiasm because he knows that what Faust has seen is not a real woman but only a creature of his mind (Cassirer 1946:5). Myth, Cassirer suggests, is a sort of enchanted glass in which each scholar has found the objects with which he is more familiar: the linguist found in it a world of signs and names, the psychologists a product of the unconscious, the philosophers both the opposite of philosophy and a form of primitive philosophy and so on. Hence the varieties of conceptions of myth and therefore also the complexity of the semantic area covered by the term. Yet, when faced with this complexity, one cannot simply disregard it.

Indeed, it is precisely because of this complexity that none of the above mentioned alternative candidates is suitable. A myth is not a simple tale, because there are plenty of tales that are not mythical. The Canterbury Tales by Geoffrey Chaucer are not myths - they might have referred to myths, they might have worked as myth in the past but, they do not seem to operate as myths any longer. On the other hand, myth is not coextensive with the concept of narrative either: it suffices to think of all the failed myths, that is of all the narratives that did not succeed in acquiring the status of myth. But a myth is not a legend either, because there are myths that are not legends, and vice versa. We can talk of the "myth of the French Revolution", but nobody would talk of the "legend of the French Revolution". At least, one can argue, that those who use the expression "the legend of the French revolution" mean something different from what is understood by "the myth of the French revolution". In particular, the former seems to imply some mystifying impact that is not necessary implied by the latter.

Finding a substitute for myth is not only impossible: it is also unnecessary. As for political myth, there is indeed today a vast literature that, from different perspectives, looks at the role that myths play in politics. Still there is a striking asymmetry in the state of the art on this topic. On the one hand, there is an ever growing literature dealing with specific case studies - beginning with the pioneering studies of the 1960 s by Norman Cohn and Eric Hobsbawm on the role of eschatological myths in peasant rebellion (Cohn 
and Hobsbawm 1963) and the long series of studies on nationalism. ${ }^{5}$ On the other hand, there are very few theoretical studies clarifying the way in which we use the concept of political myth and, even less so, dealing with the question of why this concept should be used at all.

In particular, whereas there is today an overwhelming number of historical and sociological works dealing with specific case studies, political philosophy seems to be reluctant to take the concept of political myth as an object of specific inquiry. Moreover, most of the few contemporary works that have undertaken this task, they have done so by treating political myth under headings such as "political symbolism" or, recently, "veil politics". Ajume H. Wingo, criticising Rawls's liberalism, had recourse to the metaphor of "veil politics" in order to vindicate the importance and legitimacy of elements such as monuments, flags, national heroes, political myths and rituals (Wingo 2003). According to Wingo, not only "veils" do operate in liberal democratic societies, but it could not be otherwise: they are a crucial means of political persuasion and propaganda and are not incompatible with the principle of individual autonomy, if they meet the criterion of consensus from all sectors of a nation. The problem, though, with this view is that by unifying under the heading of "veil politics" such different phenomena as flags, rituals, national heroes and political myths, not only does one lose the specificity of political myth, but one also risks ending up in a generalised defence of all sorts of "veils", and thus also of normatively problematic practices such as the cult of national heroes.

The reluctance of political philosophy to specifically focus on the concept of political myth is particularly striking in light of the tradition of philosophical studies on the concept of myth. Indeed, if the philosophical literature on political myth is very limited, the literature on myth without further qualification is endless. ${ }^{6}$ Myth has been the object of much of Western speculation: the other side of philosophy, the side against which philosophy as an intellectual enterprise has defined itself, but also that cumbersome other side that has continually recurred through the centuries, despite all attempts to rationalise it. Notwithstanding the pervasiveness of myth, both enlightened thinkers arguing for the dismissal of mythical thinking and the nostalgic romantics

\footnotetext{
${ }^{5}$ On myth and nationalism, there is now an explosive literature. Among those who have paid particular attention to the role of myths in national identities, see in particular A.D. Smith (Smith 1986; 1991; 1999). Among the historians, see for instance Stråth 2000.

${ }^{6}$ As a first approximation, see Bohrer 1983, Fuhrmann 1971, Poser 1979 or Jamme 1991.
} 
advocating for its renovation, ${ }^{7}$ have rarely deal with political myth expressly, i.e. with the specific role that myth plays in politics.

Indeed there is no vast tradition of philosophies of political myth. This can be due in part to the fact that it is only under the conditions of modernity that the specifically political role played by myth emerges as a topic: whereas in archaic societies political myths are hardly distinguishable from religious myths, it is only in modern societies, with the separation of politics from its religious anchorage, on the one hand, and with its democratisation on the other, that the role of specifically political myth becomes conspicuous. To put it in Sorel's words, when it comes to explaining typically modern phenomena such as big social movements, the fact that the people participating in them represent their action in the form of grand narratives assuring their success is so evident that there seems to be little need to insist on it (Sorel 1980: Introduction, 3).

In spite of this conspicuousness, there seems to be something in the concept of political myth that renders it recalcitrant to a philosophical treatment. Indeed, if one looks for the classical theories of political myths, one discovers that philosophers themselves have dealt more with singular political myths that with political myth in general: the theory of political myth that can be derived from Sorel's Réflections sur la violence or from Cassirer's The Myth of the State are indeed generated by a reflection on specific political myths: the proletarian general strike and the myth of the Aryan race respectively (Sorel 1908, Cassirer 1946). Indeed, it seems as if political myths have an intrinsically particularistic nature, which has not favoured the proliferation of a philosophical reflection on this topic.

On the other hand, there is nothing which would a priori hinder a philosophical treatment of political myth. In particular there are today different philosophical conceptions of myth that have stressed this particularistic nature of myth. Among them, Hans Blumenberg's concept of Arbeit am Mythos is perhaps the theory better suited to capturing this particularistic nature and that can thus better serve in seeking to understand political myth (Blumenberg 1979). A myth, Blumenberg sustained, is not a product that is given once and for all, but rather a process, a process of continual reworking on a basic mythologem, which takes place in time and reflects the changing of circumstances. If myth consists in the working on myth (Arbeit am Mythos), not only are there no single

\footnotetext{
${ }^{7}$ I am here obviously referring to the concepts of Enlightenment and Romanticism as general categories of the spirit, rather than as historical movements.
} 
myths, given once for all, but the same mythologem also changes over time because on each occasion it is re-appropriated ${ }^{8}$ by different needs and exigencies: a myth must always answer a need for significance (Bedeutsamkeit) in order to work as a myth so that, if it cannot do so, it simply ceases to be a myth (Blumenberg 1979).

Blumenberg, however, puts forward his theory more through a phenomenological analysis of single myths rather than through the development of a systematic theory of myth. In particular he focuses mainly on literary myths and does not specifically deal with political myth. Furthermore, the debate that followed the publication of his Arbeit am Mythos did not provide a theory of political myth either. The overall German Mythosdebatte, the philosophical debate that took place in Germany from the 1970 s onwards, rich as it is in theoretical insights and stimulations, does not, however, specifically focus on political myth. ${ }^{9}$ Thus even if Blumenberg's Arbeit am Mythos can be used as a basis for a theory of political myth, the political scope of his theory remains generally on the background and is not explicitly problematised.

The aim of this work is to contribute filling up the gap between philosophical theories of myth on the one hand and the social sciences' literature on political myth on the other. Among the latter, together with the huge body of literature devoted to single case studies there are also some works specifically devoted to political myth. Tudor's Political Myth is however conceived more as an introduction than as an attempt to provide a theory of political myth (Tudor 1972). As a political scientist, Tudor discusses the various theories of myth and the few classical theories of political myth, with the explicit intent of an introductory work, i.e. to simply draw attention to a common, but often neglected type of political argument (Tudor 1972).

More recent attempts to develop a theory of political myth can be found in Lincoln's Discourse and the Construction of Society and Flood's Political Myth. However, both Lincoln and Flood tend to define political myth in terms of their claims to truth - and this, even if they do not claim that myth is necessary false, is problematic from different points of view. Lincoln looks rather at myth in general, but also focuses on the specific "politics of myth". However he defines myths as those kinds of narratives that possess credibility and authority, where a narrative possessing authority is "one for

\footnotetext{
${ }^{8}$ On Blumenberg's concept of re-appropriation (Umbesetzung) see Blumenberg 1971 and Leghissa 2002.

9 The only exception is perhaps Odo Marquard: in his article on the Lob der Polytheismus he uses

Blumenberg's insights over the pluralistic character of myth for a defence of each form of Polymythie against
} 
which successful claims are made not only to the status of truth, but, what is more, to the status of paradigmatic truth" (Lincoln 1989:24). Similarly Flood, who specifically focuses on political myth understood as synthesis between political ideology and religious myths, defines political myth as "an ideologically marked narrative which purports to give a true account of a set of past, present, or predicted political events and which is accepted as valid in its essential by a social group" (Flood 1996:44; emphasis mine).

However, to define myth in general and political myth in particular in terms of its "truth" means to bring it to a terrain that is not its own. As Ludwig Wittgenstein has pointed out, a myth is not a scientific hypothesis over the constitution of the world. To put it in Wittgenstein's terms, they do not aim at putting forward a theory and cannot therefore be approached from the standpoint of their truth or falsity (Wittgenstein 1967b). Following the second Wittgenstein's philosophy of language it may be said that to interrogate myths from the standpoint of their true or false account means to assume too limited a view of what human language and meanings are about: human beings are ceremonious animals that with their language perform innumerable actions that are not based on any opinion about the constitution of the world and that do not therefore advance any claim to truth (Wittgenstein 1967b).

With regards to Flood' and Lincoln's theories of political myth one could thus simply reject them and have recourse to Wittgenstein's criticism of Fraser (Wittgenstein 1967b). Readers wishing to follow this route may skip the first part of this work and start by reading Chapter 4. This Chapter reconstructs Wittgenstein's critique of Fraser's Golden Bough and thus shows the shortcomings of an approach to myth in terms of truth, and by discussing the second Wittgenstein's philosophy of language points to the an altemative view of language and meaning better suited a theory of political myth.

The problem however remains that Flood' and Lincoln's reflect quite a common attitude in the social sciences and contains important remarks as to the way in which political myths work within a society: a philosophy of political myth would therefore result enormously impoverished if it refused to engage with them. Moreover, these views also seem to reflect quite a common attitude towards myth. Indeed, what characterises the social sciences is the fact that that they tend to take their objects as given, i.e. to move

any forms of Monomythie (Marquard 1979). Marquard's article seems to be however more devoted to make an argument against the regime of the DDR than to develop a general theory of political myth. 
from the term "myth" as it is commonly employed. Thus, even if Flood and Lincoln claim to take distance from from the common view of myth, they remain in fact entrapped in the definition of myth in terms of its claim to truth.

If we open the Oxford English Dictionary at the entry on "myth" we read: "IA. A purely fictitious narrative usually involving supernatural persons, actions, or events, and embodying some popular idea concerning natural and historical phenomena; $1 . B$. in generalized use, also an untrue or popular tale, a rumour. 2. A fictitious or imaginary person or object" (Simpson \& Weiner 1989, X, 177). In both 1 and 2, myth is characterised in terms of "fictitiousness" and "untruth", where "fictitious" - always according to the Oxford English Dictionary - does not simply means "artificial", but also "counterfeit", "arbitrarily devised", "feigned to exist", "imaginary", "not real" (Simpson \& Weiner $1985, \mathrm{~V}, 873$ ). Three features seem therefore to characterise the common use of the term: fictitiousness, unreality, untruth.

Faced with the common usage of the term one cannot therefore simply refer to Wittgenstein and Blumenberg. A philosophy of political myth situates itself between social sciences and philosophy: if it cannot simply ignore the former which tend to take their objects as given, it can on the other hand have recourse to philosophy, which typically questions its objects. With regards to the definition of myth in terms of its untruth and unreality, the approach here adopted is philosophical and consists in reconstructing the genealogy of this view of myth (Part I) and showing why contemporary thinking, at least from Wittgenstein and Blumenberg, has the means for going beyond its presuppositions (Part II).

The genealogical method, as it has been defined by $F$. Nietzsche in his Genealogie der Moral, consists precisely in facing the problem of the meaning of a certain formation by looking at the circumstances in which it has been created and thus at the values that were at stake in this process (Nietzsche 1887: preface, 3 ). In this sense, a genealogy of myth is not a reconstruction of the history of myth, but rather a critique of myth aimed at discovering what the presuppositions are of the view of myth as untruth and unreality.

To this end, Chapter 1 moves from the recognition that in the Homeric culture mythos simply meant word and was thus used as a synonym of logos. In contrast to the narrative of the birth of philosophy as exit from myth, this chapter argues that until the fourth century no opposition between mythos and logos is attested. Even if by the time of 
the sophistry the two terms began to be separated - the former specialising in the meaning of "tale" and the latter in that of "discourse, calculation" they were not yet counterpoised from the point of view of their relationship to truth. Philosophers themselves, at least up to Plato, did not disdain to have recourse to myth. Even if the professionalisation of philosophy brought with it a critical stance on the part of certain philosophers towards the old mythological tradition, not even in Aristotle is there an identification of myth with untruth and unreality. Rather, mythoi are for Aristotle the constitutive elements of poetry whose essence is the mimesis of reality.

Clearly, it is a particular conception of truth and reality that is here at stake: the ancient Greeks conceived of truth as aletheia, literally "unhiddeness", and it is only against this conception of the truth that we only can understand the plurality of Greek myths: whereas this plurality is a scandal to us and we keep asking ourselves "Did they really believe in their myths?", their view of the truth allowed a plurality of myths and of variants within a mythologem to simply coexist with each other. And it is because this plurality has been lost that the view of myth as untruth and unreal could have emerged.

Chapter 2 reconstructs one of the crucial moments for the development of the attitude to treating myths from the point of view of their claim to truth. When the logos became the revealed Word of a Unique God, the plurality of truth of ancient myths began to be condemned as deceitful. Indeed, in the monotheistic religion of the Book there seems to be something that is fundamentally hostile to the plurality of myth: this chapter argues that this consists in an absolute pretension to truth and uniqueness that leaves no space for the recognition of the polytheistic world of myth. The sacred logos thus finds itself caught in a dialectic, where, by condemning the plurality of myths, it presents itself as Holy History, i.e. as History in the singular, and thereby denies its own possible mythical nature. But once the principle of the free interpretation of the sacred logos is fully developed, it cannot but lead to the recognition of the mythical nature of the sacred logos itself and thus to the recognition of a plurality of histories.

Another crucial moment is represented by the dialectic of the Enlightenment that is analysed in Chapter 3. Following the thesis exposed by Horkheimer and Adorno in the Dialetik der Aufklarung this chapter explores the dialectic in which any absolutisation of scientific logos, here analysed in the form of an ideal-typical Enlightenment, risks to fall (Adomo Horkheimer 1944). In particular it argues that the Enlightenment, by condemning myth for its subjectivity, hides the fact that myth is already "enlightenment" 
inasfar as it concerns telling and finding out the origins of things and, at the same time, it reinforces that separation between the knowing subject and the known object upon which scientific logos itself rests. It is from the point of view of the Enlightenment that myths are condemned not just as untruth, but also as imaginary and thus unreal. On the other hand, romantic theories of myth, with their call for a rehabilitation of myth understood as totality and as the vehicle for a divine revelation, rather than radically questioning Enlightenment simply inverts the axiological value of the dichotomy of myth versus reason upon which Enlightenment itself rests.

However, reflections on the nature of language and meaning post linguistic-turn have gone beyond the presuppositions of the dialectic of Enlightenment and also of the very opposition between an enlightened and a romantic view of myth (Chapter 4). In particular, the second Wittgenstein, which is a central author of the linguistic turn, has definitely shown that any distinction between an expressivist and a designative view of language is essentially flawed because meanings are only possible through languagegames where no distinction between the two can be drawn.

Chapter 5, moving from both the genealogy of myth and the discussion of Wittgenstein's philosophy, tries to delineate a possible approach to myth which escapes both the dialectic of the sacred logos and that of the Enlightenment. In contrast to the criticism raised by the logos against the plurality of myth, the Chapter argues firstly in favour of an inter-relational approach to myth, i.e. of an approach that, following Blumenberg, focuses on the Arbeit am Mythos; secondly, in contrast to the Enlightenment's discourse about the unreality of myth it proposes to adopt a phenomenological approach which leaves the problem of reality between parentheses. Chapter 5 continues thus by pointing to four fundamental features of the working on myth: 1. it operates with figurative means, 2 . it is not limited to a particular set of contents; 3. it coagulates around a narrative; 4.it answers and provides what Blumenberg has called Bedeutsamkeit, i.e. significance.

Blumenberg's concept of significance is discussed in Chapter 6. Myths provide names through which the unknown becomes first masterable, but they also provide narratives which, by inserting events into a plot, can produce and reproduce significance. This leads back to Gehlen's characterisation of human beings as noch nicht festgestellte Tiere (Nietzsche): human beings in contrast to other animals, are not adapted to a specific environment. As a consequence they are not only weltoffen, and thus exposed to 
all sorts of stimulations from which they must seek relief through the creation of meaning, but they also interrogate themselves over the conditions of their own existence and must therefore make significance of them. As Kerenyi has also pointed out, the function of myth is begründen.

Chapter 7 serves as a passage from the preparatory parts dealing with myth in general to the parts specifically devoted to analysing the role that myth thus conceived plays in politics. In particular, to assume that, since political modernity has liberated politics from its religious anchorage, it must also have liberated it from myth means to take the point of view of Enlightenment, which assimilates myth and religions under the heading of superstition. Myths however are not religion, and therefore they can be a possible means of critique. By exploring the working of one of the most powerful myths of modern political theory, i.e. the myth of the state of nature, and the way in which the working on this myth changes in different authors and contexts, the chapter concludes that myth is not in principle incompatible with the idea of autonomy and that, as Rousseau's uses of this myth shows, it can rather be an important means for critique.

This view of political myth clashes with the view emerging from Cassirer's treatment of myth. His view is discussed in Chapter 8 , which is devoted to reconstructing the classical theories of political myth. After rejecting Cassirer's definition of political myth as collective desire personified because it is too dependent on the totalitarian model, on the one hand, and to the premises of Enlightenment on the other, the chapter focuses on Sorel's theory of political myth as it emerges in his discussion of the general strike. With his emphasis on the pouvoir moteur of myth that makes sense - but we would say significance - of the present by providing a vision of a future catastrophe, Sorel points to the fact that myth is not a description of things, but rather a determination to act. However he does so from the point of view of a problematic theory of two selves.

Looking within modern political theory one may find another author who has dealt with political myth and whose remarks on this regard seem to provide crucial insights for a philosophy of political myth that goes beyond any form of dichotomy of "mythos versus logos". Baruch Spinoza is perhaps also from this point of view an anomaly of modernity. In his analysis of the role played by prophecy in the constitution of the ancient state of Israel, Spinoza points out that prophecy is a product of imagination understood as an idea produced on the basis of present or past bodily impressions. Prophecy is thus valid because the prophet is morally certain of his knowledge and this 
moral certainty derives from the fact that he belongs to a community whose rules and laws he embodies. Thus, whereas for Cassirer myth is a form of regression into a primitive form of consciousness and social organisation, and for Sorel it is a means for progress, Spinoza seems to sustain that if myths operates in all societies, what they differ in is the degree to which these mythical beliefs are subject to open and free discussion.

To sum up, Chapter 9 concludes that a political myth can be defined as the working on a common narrative by which the members of a social group (or society) make significance of their political experience and deeds. Thus what makes out of a simple narrative a political myth is not its content or its claim to truth, but rather the fact that this narrative creates significance, it is shared by a group and can come to address the specifically political conditions in which this group operates. As a consequence the chapter argues that political myth must be kept distinguished at the analytical level from ideology, on the one hand, and from utopia on the other.

Chapter 10 looks instead at the consequences that this definition of political myth implies for the relationship between political myth and historical narratives. Even if both are constitutive of what Castoriadis has called the social imaginary and even if quite often they are intermingled, this chapter argues that the two categories must be kept separated: when we say that a certain historical narrative is a political myth we mean that this narrative has come to work in a particular way, i.e. as a narrative the makes significance of certain political experiences and deeds.

Finally, Chapter 11 looks at the role that myth plays in the constitution of common identity. By critiquing Schmitt's view of political myth as a symptom of the national energy, this chapter maintains that myth is not only the product but also the producer of common identities. Against Schmitt's holistic treatment of identity, the chapter argues for a distinction between different forms of identity - identity with an adjective: personal, social, cultural and political identity, etc - without nevertheless ignoring the possible interactions between them. In particular, it is precisely the working on political myth, which plays a crucial role in the construction of common identities, that stresses how problematic it can be in reality to separate cultural from political identity.

This argument emerges again in the last chapter with the analysis of some possible sites for the working of political myths today. There are narratives that do not contain anything political per se, but by working within certain contexts they can come to 
create significance and to contribute to the shaping of common political identities. More than a definitive conclusion, this chapter puts forward some hypotheses as to the forms that the working on political myth could assume under the contemporary conditions of a globalised society of spectacle. There are reasons to suspect that it is precisely in our epoch, which has aspired to get rid of the grand political narratives, that the working of political myth has become much more insidious than it has ever been in the past. 


\section{A GENEALOGY OF MYTH}

According to a common view, myth is defined in terms of its untruth and unreality. ${ }^{10}$ The task of a genealogy of myth is to reconstruct the presuppositions of such a view. Following Nietzsche's definition of the genealogical method (Nietzsche 1887), a genealogy must address the question "what is $x$ ?" by, at the same time, asking "why we conceive of it in this way". As Nietzsche pointed out, a genealogy faces the problem of meaning by looking at the circumstances in which it has been created and thus at the values that were at stake in its creation (Nietzsche 1887: preface, 3 ). ${ }^{11}$

In this sense, genealogy is a form of critique (Nietzsche 1887: preface, 7). In contrast to the type of critique developed by Kant, however it does not aim at providing a transcendental fundament. A transcendental critique, according to Nietzsche, can easily turn into the opposite of the critique, i.e. into the hypostatisation of a particularistic view and of the values that it presupposes (Nietzsche 1885, V). As Nietzsche puts it in the letter to Overbeck of the 4th of January 1888, the genealogical method aims to set up a critique of a given formation through the "artificial isolation" of some of its different hearths (verschiedenen Entstehungsheerde) (Nieztsche 1984: 224).

Therefore, the following genealogy of myth must not be understood either as a history of myth or as a simple reconstruction of the origin of myth. In particular, inasfar as it aims at isolating some of the different hearths that generated the view of

${ }^{10}$ See for instance myth in the Oxford English Dictionary (Simpson \& Weiner 1989, X, 177). For a wider discussion, see Introduction.

"On the relationship between meaning and values in Nietzsche"s genealogical method, see Deleuze 1962 , I, 1 . 
myth as untruth and unreality from which we started, the genelogy proposed will not focus on the continuity of the history of myth, but rather on its discontinuities.

In their Dialektik der Aufklärung, Horkheimer and Adorno put forward the thesis of a mutually dialectic constitution of myth and logos (Adomo \& Horkheimer 1944). As has been observed, the approach they have developed in this book is an example of a Nietzschean genealogy (Habermas 1985, 5). However, whereas they applied the genealogical method to the Aufkläning in order to show how it constitutes itself by rejecting the myth, a genealogy of myth rather starts from myth and looks at the different hearths that produced such a view.

As a consequence, the follwing genealogy of myth focuses on the way in which myth is related to the logos understood in different ways - first as logos without further specification (Chapter 1), then as sacred logos (Chapter 2) and, finally, as scientific logos (Chapter 3 ). This has many important consequences that will become clear later on. Now, suffice is to say that whereas Horkheimer and Adomo move from Aufklärung, i.e. modern rationality, and then project it back to the Greek logos, in order to show the continuity between the two, a genealogy of myth, rather, moves from the Greek mythos and then tries to reconstruct the discontinuities of its genealogy

Starting from the Greek mythos may appear arbitrary from the point of view of its spatial temporal limitation (Jamme 1999). A reply to this objection is implicit in the concept of genealogy sketched above. A genealogy does not aim at any kind of exhaustiveness - in either space or time, nor at setting up a comparison between the ways in which different cultures across the globe have conceived of myth. It merely seeks to interrogate a certain view of myth, namely a view that identifies it with "unreality and untruth", and then, by looking for its discontinuities, tries to reconstruct its presuppositions. 


\section{MYTHOS AND LOGOS}

Mythos is a Greek word and it originally meant "word, speech". According to certain etymologists, it derives from a popular expression constituted by the onomatopoeic sound $m u$ - (the sound that we produce with a closed mouth), and the common suffix -thos. ${ }^{12}$ In the Homeric poems, mython eeipe is, for instance, the standard expression used to mean "he said", without adding any further connotations (Tebben 1994, 902; 1998, 1155). ${ }^{13}$ In these poems, the primary meaning of the term is that of "word, speech", even though, as secondary meanings, the term is used in the sense of "public speech", and also "dialogue, conversation" or "tale, narration" (Liddell \& Scott 1968, 1151).

Thus, by the time of the composition of the Homeric poems - a time that most interpreters collocate around the eighth century $\mathrm{BC}$, the semantic area of the Homeric "mythos" corresponded then to the area that would later be covered by the term "logos". ${ }^{14}$ Indeed, whereas in the Homeric poems, the term logos is almost absent there are only only two occurrences, one in the Iliad $(\mathrm{XV}, 393)$ and one in the Odyssey $(\mathrm{I}, 56)$, the term logos entered progressively into common usage up to a point when it took the semantic space once occupied by mythos. This latter began at the same time to

${ }^{12}$ For a discussion of this etymology, see entries "mu-" and "mythos" in Chanteraine's Dictionnaire Etymologique de la Langue Grecque (Chanteraine 1984: 717 -718).

${ }^{13}$ In the 153 occurrences mytho* of the Odyssey, we have mytho* eeipe 20 times and mytheomai, to tell, to speak, 37 times(Tebben 1994: 902); in the llias, there are 146 occurrences for the entry mytho*: the expression mytho* eeipe recurs 33 times and the verb mytheomai, "to tell ", appears 20 times (Tebben 1998: 1155).

${ }^{14}$ According to some interpreters, mythos in Homer would designate a specific kind of speech, namely an authoritative speech act - the prototypes being the public declamation of the poet (Martin 1989). Despite these divergences, scholars agree on the basic meaning "word, speech" and therefore on semantic proximity between the two areas mythos, mytheomai and logos, legein - as it is attested by the expressions that combine 
express the additional meaning of fanciful tales. According to Chanteraine, this passage is fully attested in the works of the tragedians and Plato: it is here that the term mythos tends to specialise in the sense of "fiction, mythe, sujet d'une tragédie" (Chantraine 1984: 718).

Thus, a genealogy of myth starts with "mythos" meaning simply "word, speech" and being thus almost a synonym of "logos", while by Plato's time a new meaning, together with the old one, has emerged. What happened in between? Which forces determined such a passage? According to a common view, it is the "birth of philosophy" that, by giving rise to a fundamentally new approach towards the world, determined the eclipse of the old mythological tradition and relegated the semantic ambit of mythos to that of pure "fiction". In this view, the activity initiated in the Ionia of the seventh century BC by the first "naturalist philosophers"15 represents the exit from the world of myth. For the first time, these thinkers searched for a rational underlying principle of the world (arché) - identifying it first with water (Thales), then with apeiron ${ }^{16}$ (Anaximander) or finally with air (Anaximenes). In so doing, according to W. Nestlé, they rejected any mythological explanations and opened the Western road from "mythos to logos" (Nestlé 1942).

Thus, the argument about the "birth of philosophy" was linked with the idea of a Western development from "mythos to logos". "Vom Mythos zum Logos" was the title of Nestlés very influential book and it well captures ideas that were widespread at the beginning of the twentieth century (Nestle 1942; Burnet 1920). These views, elaborated in an epoch of crisis, served not only to provide an identity for the so-called European or Western civilisation, but also to supply an ideological covering for its political expansionism. That is to say, the argument concerning Europe as the birthplace of philosophy was used to justify the superiority of Western civilisation: even when the argument did not take the explicit form of a panegyric upon "the extraordinary intelligence of the Greek men" fathers to the European civilisation

the two areas, such as the above mentioned mythos eeipe or the verb mythologeuo, which simply meant "to tell words" (Liddell \& Scott 1968: 1150).

${ }^{15}$ As we will see later on, this is Aristotle's definition. Indeed, it was Aristotle who attributed to these figures both the status of first philosophers together with that of "naturalists" philosophers.

${ }^{16}$ The term "to apeiron" is often translated with "the indefinite" (see for instance Kirk, Raven, Schonfield 1983). Others more accurately translates with "Non -limited" (Freeman 1966). It literally means without boundaries, so that a good translation could be "boundless". 
(Bumet 1920:10), it lent itself openly to providing an ideological justification for European colonialism. ${ }^{17}$

The idea of a "Western road from mythos to logos" is still widespread. Kirk adds a question mark to the tile of his essay "From myth to philosophy?" and thus vindicates his perplexities about the narrative of the "birth of philosophy" as a linear development from mythos to logos. These perplexities stem from his critical stance towards the idea of there being a sharp dichotomy between "mythos" and "logos" (Kirk 1970, 1974: 277ff). All the same, he still maintains that the birth of philosophy does imply the dismissal of myth. As he radically concludes in his essay: "the organic use of myths has to disappear before philosophy becomes even a remote possibility" (Kirk 1974: 279).

Jean-Pierre Vernant who also problematises the idea of a linear "Western exit from myth", still argues that the "birth of philosophy" represents the "beginning of rational and positive thought" (Vernant 1965). His essay on La formation de la pensée positive dans la Grèce archaïque thus begins with the following words: "Rational thinking has a civil status (état civil); we know its date and place of birth: it is in the sixth century BC, in the Greek cities of Asia Minor that a completely positive, new form of reflection on nature emerged (Vernant 1965: 374; trans.mine).

In the following pages, Vernant continues by criticising the argument of those, like Burnet, who presented this passage as a sort of miracle that is explicable only in terms of the extraordinary intelligence of the "Greek man" (Vernant 1965: 374; Bumet 1920: 10). It was not a miracle, Vernant replies. Coming from the ranges of structuralist and Marxist historiography, he could not believe in miracles. Nevertheless, in his view, this event still represents "such a deep change in mentality" (changement de mentalité) that we should nevertheless see in it the "act of baptism of Western man, the emergence of the true spirit, with the values that we" - read Marxist structuralists "can recognise in this term" (Vernant 1965, 11; transl. mine).

Such a change consisted, according to Vernant, in the fact that, with the socalled "naturalist philosophers" the explanans assumed for the first time, instead of

"It would seem that the term "civilization", which implied from its very origins an opposition between "civilized" and "barbarian", has never completely freed itself from this original connotation of the "superiority" of the "civilized" (Fisch 1992:688, 785). Recent theories about the multiplicity of civilizations can thus be read as the (later) recognition that there is a plurality of "civilized peoples", but the concept of "civilization" still involves a fundamental judgement about superior and inferior forms of cultures. For a 
personified agents, the form of an abstract quality - as it is underlined by the new use of the article " $t o$ " " in expressions such as "the humid" or "the hot". In other words, these thinkers were looking for "the hot", a reality defined by the positive action of warming up, and not by some mythical power such as Hephaestus or any other mythical figure. Therefore, their theorising, according to Vernant, represents the moment when positivity invaded the being and led to the consequent dismissal of myth: "Among the physicians, positivity had at once invaded the totality of being, Gods and human beings included. Nothing real that is not nature" (Vemant 1965: 381; trans. mine).

Surprisingly this argument followed the recognition of some kind of continuity the between mythical tradition and the theories of the Ionians. For instance, Vernant recognises that there are some similarities between the conceptual structure employed by the Ionic physicians and by Hesiod's cosmogony. In the first place, Hesiod had already presented the creation of the world by recurring to characters such as "chaos, the "earth", the "sky", which, as their names point out, can be interpreted in purely "naturalistic" terms. Even more: the conceptual apparatus of Hesiod's cosmogony and the view of the world put forward by the Ionic philosophers seem to correspond in details. In both cases, the origin of the world is seen in terms of 1) chaos at the beginning; 2) the separation of pairs of opposites such as hot and cold, dry and humid, and so on, out of the primordial unity, and 3) the reunification and interaction between the opposites (Vernant 1965: 378; Cornford 1952). Where, then, does the difference lie?

In other words: if, as Vernant maintains, the first philosophers were, by looking for the arché, searching for a deeper level of reality, something "beyond nature itself" (Vernant 1965, 383), in what sense can these theories be said to be "positivist"? Otherwise stated, how could these philosophers have been so positivist if they recognised the existence of something real that is not "nature" itself? Vemant seems to recognise this impasse later on in his text and tries to escape from it by saying that even if these philosophers used the same conceptual apparatus of the old mythical tradition, they were doing so in a revolutionary way. According to Vernant, whereas in myth the separation between different levels of reality generates confusion, in philosophy it brings clarity (Vemant 1965: 383).

critique of this concept, as it has been recently recovered in the so-called "axial age debate", see Wagner 2004. 
The argument at this stage cannot but give the impression of circularity: the same conceptual system generates confusion in myth because it is a myth, whereas it leads to clarity in philosophy because it is philosophy. No other explanation of the difference between the two is yet available at this level of the argument. To understand in what this difference consists, we have to wait for the pages where Vernant describes the emergence of cities. Here, the separation between the different levels of reality operated by philosophy in contrast to myth acquires a new sense: the revolution is said to consist in the fact that with these theories "thinking" is completely separated from "physical reality" as if they had been separated by an axe (comme à la hache) (Vernant 1965: 400) and that this separation at the level of mental forms corresponds to the separation between society and nature that the emergence of the city realized at the level of the social forms (Vernant $1965: 392$ ).

Thus, according to Vernant, there is a strong connection between the birth of philosophy and the emergence of the "citizen", because the city operates according to Vernant a separation between nature and society which the "presupposition of rational thinking" (Vernant 1965: 392). Here therefore lies the greatest break with the world of myth: whereas this latter, according to Vernant, distinguished, but confused different levels of reality, philosophy clearly jusxtaposes physical reality to thinking itself, much as the polis, at the level of social forms, contrasts nature with society.

In Vernant's view, then, it is not the presumed "superiority" of the "Greek man's intelligence" that produced philosophy, but that of an entire political, economic and mental world - a world that resulted from the changes which took place in the Ionia of the seventh century BC. According to this view, whereas human beings were unable to distinguish between different levels of reality until the rise of philosophy, or at least they did so in a confused way, after this change of mentality, "thinking" became separated comme à la hache from physical reality (Vernant 1965, 400). Reason, on the one side, and physical reality, on the other: here were the beginnings of positive thinking, the act of "baptism of Western man" (Vernant 1965).

It is very difficult to evaluate the different accounts of the "birth of philosophy". The sources upon which they rest are very few and precarious in the sense that they are highly dependent on what later interpreters estimated as worth transmitting. We do not even possess fragments of their own texts: the so-called "fragments of the presocratics" are either "testimonia", i.e. comments made by later 
authors on their theories, or "direct quotations", i.e. quotations made by subsequent ancient authors. Doubts over a linear account of the "birth of philosophy" thus seem to be legitimate.

In the first place, one can observe that it is very difficult to see how the alleged separation "comme à la hache" between thinking and reality could ever be attributed to the so-called first naturalist philosophers. For instance, we have many signs that the separation of the logos, understood as "thinking", and what Vernant calls "physical reality", was unknown even to later philosophers. Indeed, such a separation, with which we are now so familiar, seems to be alien to ancient thought, since the term logos indicates a being and a thought at the same time (Abbagnano 1971:547). I will come back later to this point. If we look at the other side of Vemant's presumed separation between "thinking" and "physical reality", the problematic character of such a separation is even more manifest. The Greeks did not even have a word to designate what Vernant called "physical reality", their corresponding terms being ousia and physis. Physis, however, indicates nature in the most general sense: the term derives from the verb phyein "to rise", whish is in its turn etymologically linked to phainesthai "to show itself". Physis is therefore literally "what shows itself", "what comes to light" and thus indicates a much broader reality than a "physical positive reality". The term ousia designates instead what we call "reality" but in the sense of the "immutable or true reality" i.e. reality understood as substance (Liddell \& Scott 1968: 1274). ${ }^{18}$

On the other hand, it is not difficult to recognise in Vernant's separation comme à la hache of the "logos" from "physical reality" the modern separation of the knowing subject from the known object, which is at the basis of the modem gnosiological approach and which accompanied the birth of the modern science. Indeed, what seems to be at work here is a strategy of re-appropriation of the past in order to provide an identity for a much later cultural enterprise. By going back to Vernant's words, one can say that what is at stake in the debate over "birth of philosophy" and in the narrative of a "Western road from myth to logos" is primarily the search for the civil status of Western rationality (Vernant 1965, 373).

The emphasis given to the "birth of philosophy" as the greatest rupture in the passage from mythos to logos is linked to the fact that this moment worked over the

\footnotetext{
18 To bypass this difficulty, Vemant has to postulate a presumed split within the concept of physis (Vernant $1965,381-382$ ), a split that is not, however, supported by the sources and seems, on the contrary, to contradict the documented uses of the term physis.
} 
centuries as a powerful means for the self-identification of Western rationality. The idea of "the birth" of philosophy has been used in order to provide Westem rationality with an identity. This is clear in Husserl's The Crises of the European Sciences: it it when faced with the European crisis that he moves back to the Greek nation of the seventh and sixth centuries BC, presenting it as the birthplace of the "spiritual shape of Europe" (Husserl 1935). In Husserl's view, the new "theoretical" attitude, to which the earliest Greek philosophy gave rise, not only helps to identify the "distinctive European spiritual shape", but is also aimed at finding a possible cure for the crisis that this spiritual shape is facing. Thus, this re-appropriation of the past not only provides an identity to the "European sciences", but also gives orientations for acting in the present.

In this way, Husserl followed a long-lasting strategy of self-definition through a reappropriation of the past. But what are the bases for saying that it is with the Ionian physicians that philosophy began? As we have seen, the sources that we possess for the reconstruction of the thinking of the so-called presocratic philosophers depend on later testimonies. Among these latter, Plato and Aristotle played a primary role. Plato is, however, very vague in his quotations: he is much more interested in the dialectic confutation of the arguments exposed and, consequently, he often does not even quote the author. Instead, Aristotle indubitably paid greater attention to his predecessors, but the price we pay for this is that his reconstruction is strongly shaped by his own view of these philosophers as first steps towards the truth contained in his own philosophy. ${ }^{19}$

Standing behind the whole narrative of the "birth of philosophy" there is thus primarily the authority of Aristotle (Colli 1975, 1977, 1978a,b). Indeed, it was Aristotle himself who first spoke of Thales and the Ionians as the "first philosophers" and as the "naturalist philosophers". This interpretation is developed at the beginning of his Metaphysics, where he puts forward his own view of that specific activity which would be called "philosophy" thereafter. After having described philosophy as the search for the first principle and causes (Met. 982a-b), he presents the conceptions of Thales, Anaximenes and Anaximander as first steps in this search and therefore as the "first natural philosophers"..

Aristotle's reconstruction of the "birth of philosophy" has therefore the clear function of preparing the presentation of his own doctrine of the four causes. These

${ }^{19}$ On this point, see for instance Adorno $1961 \mathrm{a}$ and Colli 1977, $1978 \mathrm{a}, \mathrm{b}$. In his philological work on the Presocratics, Colli sharply questions any naïve reliance on Aristotle's testimony. 
latter are presented as the final result of the previous speculation, and in particular of that of the first naturalist philosophers, so that it becomes, of course, very difficult to judge where their alleged theories end and Aristotle's begins. The influence of Aristotle's authority on this point can hardly be overestimated. He played a major role not only in the interpretation of the work of the first "natural philosophers" but also in the presentation of the whole cultural enterprise that goes under the heading of "Western philosophy". For centuries Aristotle's words represented the act of baptism of the specific discipline designated as "philosophy" and for many also a crucial, if not the crucial, moment for the self-identification of the West itself. ${ }^{20}$

Some doubts can, however, be raised over this narrative as a whole. First, some scepticism seems legitimate because, as we have seen, the sources upon which this narrative rests are narratives whose authority is highly dependent on those, particularly Aristotle, who first formulated them and who were most often more interested in putting forward their own view of philosophy than in reconstructing the thinking of the Ionians. Second, since we know nothing about the silence surrounding those very few sources upon which this narrative rests, it might well be that some "philosophers" that did not fit into Aristotle's reconstruction and in Aristotle's definition of what it means "to be a philosopher" existed, but were simply neglected. In particular, if one assumes that philosophy means critique and is thus an attempt at providing a rational explanation of the world, then it is very unlikely that nobody else had already "philosophised" about the world apart from Aristotle's "first naturalist philosophers". To take Vernant's example, it is very unlikely that human beings were all making recourse to Hephaestus in order to explain the phenomenon of "the hot".

On the other hand, even in the case of the "philosophers" presented by Aristotle, there are good reasons for questioning his reconstruction. For instance, in the case of Thales' thinking, there is a fragment that suggests an alternative interpretation to Aristotle's. According to this fragment, Thales would have said that "all things are full of gods" (panta plera theon einai) (Diels \& Kranz 1938, Fragm. 22; Kirk, Raven \& Schofield 1983, 95). This fragment seems indeed to refer to a view that comes close to what Vernant called a "mythical conception of reality", i.e. one where different levels

\footnotetext{
${ }^{20}$ Husserl's approach, as we have seen, is paradigmatic from this point of view (Husserl 1935). More recently, for instance the narrative of the "birth of philosophy" has entered the debate about the European identity. According to some interpreters, "the birth of philosophy" is precisely what characterizes the specific "spiritual shape" of Europe. For a general reconstruction of this debate, see Friese and Wagner 2002.
} 
of reality are fused together. Despite the obscurity of the formulation and the consequent difficulty in providing any univocal interpretation of this fragment, it seems clear, however, that we are a long way away from the image of the "positivist natural philosopher".

Finally, as has been recently pointed out, the idea of the "birth of philosophy" as an exit from myth, contrasts with the fact that even in later sources "mythos" can never be said to be totally "irrational", and no "philosophy" is totally deprived of mythical elements (Morgan 2000). Not only, thus, as we have seen, were the conceptual tools of the so-called first philosophers not very dissimilar from, let us say, those of Hesiod's, but - furthermore - the very fact that later "philosophers" often recurred to myths in their writings is a sign that the boundaries between "mythos" and "philosophy" were far from clearly delineated (Morgan 2000).

The fact that philosophers themselves make recourse to mythical narratives when dealing with philosophical issues should not come as a surprise. The presocratics were considered sophoi. The sophos was a figure in between poet and shaman, more precisely someone who excelled in knowldge (see Colli 1975, 1977, 1978a, 1978b). Both their contemporaries and Plato called the presocratic philosophers sophoi, so that instead of speaking of "presocratic philosophy" we should probably better speak of "Greek wisdom" (Colli 1977, 1978 a, b). The sophoi did not write textbooks on physics, nor philosophical texts in the sense of the literary genre initiated by Plato and Aristotle. They wrote poems peri physeos (On nature) that were destined for oral transmission and diffusion. And, as we have seen, the physis that is the object of their poems is not our "physical reality": rather, it is nature in its most general sense, the sphere of the totality of being that, literally, comes to light.

The dynamic interpenetration of myth and philosophy is also reflected in the semantic proximity of the two terms "mythos" and "logos". No sharp dichotomy between mythos versus logos was indeed yet stated at least up to the fourth century BC (Morgan 2000). Herodotus, for instance, uses "mythos" only twice, but, as has been observed, he uses the term "logos" in a way which corresponds to what we would today call "myth" (Morgan, 2000, 19ff). When narrating two different versions of Helen's arrival in Troy, he calls them both logoi, even the version that he does not believe is true (Herodotus II, 116). Thucydides, who, by condemning the "mythodes", the "mythical element" (Thucydides, I, 22), also started a new phase of more 
ostentatiously "scientific" historiography, did not make any definitive association between mythos and false speech or even with what we would today call "myth" (Morgan 2000, 20).

The association between these two is, at best, the result of the later selfpresentation of intellectuals willing to distance themselves from the world of myth. An important role was probably here played by the movement of the so-called "sophistry". With sophistry began a process professionalising philosophy. The sophists aspired to be recognised as professional teachers for the technique of reasoning (dialektike techne), the importance of which increased notably in the fifth century Athens. According to Plato, the sophists labelled the rhetorical, dialectical and literary education that they were teaching to youths wanting to start a political career as philosphy (Symposium, I, 5). Indeed, it is with the centralisation of the cultural life in Athens and with the political climate of the middle of the fifth century that dialectics massively entered the political arena: it was then that the sapientia of the old sophoi entered in competition with the "dialectics" of Gorgias and Protagoras.

The sophists, in their attempt to present themselves as new professional figures, attempted to clearely distance themselves from the world of the traditional poets such as Homer and Hesiod. According to the platonic dialogues, it was at that time that mythos took on, together with the general meaning of tales, the further connotation of fable, fictitious narrative (see for instance Plato's Gorg. 527a, 5; Phil. 14a.4; Phaedr. 60c.2; Soph. 242c.8, d.6; Resp. II, 377a.4, b.6, d.5, 379a.4). However, no sharp opposition between mythos and logos was yet part of the common meaning of the term. Even for the sophists, the old mythoi were part of a reservoir of traditional material to which they themselves did not disdain to recur in their art of constructing discourses.

According to Plato's testimony, learning to express one's arguments in the form of the logos and the mythos was part of the basic training in the rhetoric-dialectic curriculum: on the one hand, there was the demonstration of truth based on rational argumentation, and, on the other, its narration through figurative expressions. For instance, Protagoras, who represents the professional "sophist" in the homonymous platonic dialogue, asks Socrates whether he wants an argument to be delivered in the form of the mythos or of the logos (Protag. 320c.3, 320c.7; but also 324d.6 and $328 \mathrm{c} .3$ ). In many platonic dialogues, indeed, we are given the impression of a double 
track of the arguments: discursive arguments, on the one hand, and mythical narratives, on the other. The Phaedo is paradigmatic from this point of view because for every bloc of dialectic arguments there is a correponding group of mythical narratives (Phaedo 80b.ff; 107c.ff). ${ }^{21}$

This confirms the fact that the further connotation of untruthfulness entailed by myths was not yet part of the primary meaning of the term. Thus, whereas the narrative of the "birth of philosophy" as an "exit from myth" would seem to suggest a linear road "from mythos to logos", if one looks more closely at the sources upon which such a narrative rests, not only does one find that the very few fragments may reflect Aristotle's conception of philosophy more than that of the Presocratics, but that even later sources suggest quite a different story: far from being counterpoised to each other, a proximity between the two is suggested at least up to the fourth century BC. Indeed, if Plato can continually move in his dialogues from rational argumentation to the narration of myths, this is because the question of the "truth or reality of myth" had not yet been posed: the mythos was generally juxtaposed to the logos simply as a different way by which to express a similar content and the difference between the two was held to be on the level of their different protreptical impact, and not of their respective truth or reality.

Plato's constant recourse to myth is perhaps the most conspicuous scandal for the narrative of the "birth of philosophy" as the exit from myth. ${ }^{22}$ Different strategies have been historically employed in order to reconcile them: platonic myths have been read both as the containers for a kind of truth which is superior to that entailed by the logos, and as a primitive way of expressing a truth which was to be superseded by the logos itself. An example of the first approach can, for instance, be found in Joseph Pieper, who conceives of platonic myths as a message from a divine source - on analogy with the idea of the original revelation that would later be developed by Christendom (Pieper 1965). The second approach is more common and sees among its supporters Hegel. According to Hegel, platonic myths are simply beautiful representations to which Plato make recurse only for pedagogical purposes or because he cannot give "more pure representations" of the thought. Myths are thus said to be a

${ }^{21}$ On this point, see Reale 1991: 74, 124.

${ }^{22}$ It should also be noted here that, as Colli observes, although Plato is the first thinker to explicitly call his own activity philosophy, this does not mean that he is in this way distancing himself from the old tradition of 
form of "pollution of thinking through sensitive images" (Verunreinigung des Gedankens durch sinnliche Gestalt), which would be avoided by Plato in any case when he has to express the crucial parts of his argumentation (Geschichte der Philos., XIX: 29-30).

Many objections can be raised against both these interpretations. It is, for instance, quite difficult to see how Pieper's interpretation could suit a myth such as that of the cave, which is used by Plato to describe his conception of the different levels of knowledge and the role of philosophers in society (Resp. 514A-521C). The human condition can be described, according to this myth, as that of people in a cavern who are fettered in such a way that they can only see the bottom of this cave. Having always been imprisoned in this way, they believe that what they see at the bottom, namely, the shadows produced by statues outside the cave, are the things themselves. Philosophers can be seen as those people who, having liberated themselves from these fetters, were given the opportunity to see not only the things directly but also the sun itself, i.e. the idea of the good (Resp. 517c). Having been given the opportunity to contemplate the idea of good, i.e. - in Plato's view - the source of being, philosophers must then go back to the cave in order to help their fellows free themselves: even if they take a great risk in doing so, because their fellows, imprisoned as they are by the appearances, may not believe in them, this is nevertheless the philosphers' duty (Resp. 519c.ff).

This myth, like many others in Plato's writings, is presented as a figurative description of a philosophical theory, rather than as a "revealed truth", which is impossible to express in rational terms. The myth of the cave also suggests, against Hegel's interpretation, that Plato commits not only marginal or introductory themes to myth, but rather very crucial parts of his conception. This holds for the myth of the cave, which is introduced by Plato to explain his theory of knowledge and his conception of the role of philosophers in society, but also for the myth of races or the myth of Er in the Republic, or the myth of the chariot in the Phaedrus, and many others can be added to the list (Thaet. 156c.4, 164e.3; Laws I 645b.1; Tim. 69bl).

Furthermore, Hegel's view seems to contrast with what Plato says in the Seventh letter, i.e. that the most important part of his own philosophy is not contained

the sophoi. Rather it seems as if by calling his own activity "philo-sophia" he was referring precisely to the past tradition of the sophoi (Colli1975: 13). 
in his dialogues $(341 \mathrm{C}){ }^{23}$ This statement has been widely debated, but most interpreters agree in relating it to the criticism Plato raised in many places against the "written word"(Protagoras 329A, Phaedo 276C, 277A, 277E, Phaedrus 274 C-278 E). In an epoch when Greek culture was still moving from a culture of orality to literacy, Plato proposed considering the practice of writing only as a "medicine for the memory" which should never substitute the practice of dialoguing (Phaedrus 274 C-278 E). In his opinion, the written word is "dead" because it is unable to give answers if you interrogate it, whereas the "discourse written in the soul of the disciple" is alive, and he is thus able to defend himself and distinguish the appropriate moment for speaking or being silent (Phaedrus 276A).

In this line of interpretation, the myth - as a figurative expression - could be held to entail a surplus of meanings acting as a stimulans for thinking, and could be considered as a way of overcoming some of the shortcomings of the practice of writing. Rather than providing an inferior means of argument, platonic myths could on the contrary - be interpreted as way of expressing a conceptual content which is superior to rational argumentation, because, whereas this latter, once is translated into a single written form, is dead, myths are open to a generation of meaning that can always generate further discussion. ${ }^{24}$

Furthermore, both Pieper's and Hegel's interpretations seem to reflect later worldviews too closely: Piper's view is clearly linked to the Christian conception of revelation, while Hegel's approach is a good example of the typically modern attempts at rationalising myth. In both cases, mythos is placed on a heterogeneous level with respect to logos - standing either above or below it. In both interpretations, mythos and logos are considered as counterpoised, whereas, as we have seen, by the time of Plato, myth was most probably seen as a means to express a content that could also be developed through rational argumentation.

\footnotetext{
${ }^{23}$ Some interpreters read this passage in connection with Aristotle's testimony on Plato"s "unwritten doctrines" (agrafa dogmata). See in particular, the work of the so-called "Tübinger Schule", whose major representatives, in their attempt to revaluate the indirect platonic tradition as fundamental for an accurate image of Plato, strongly emphasise Plato's scepticism towards the practice of writing (Krämer 1982, 1995; Geiser 1963; Reale 1986).

${ }^{24}$ The extent to which literacy influenced the rise of philosophy is still very controversial. Among those emphasising the impact of literacy for the rise of abstract rational thought, see Goody \& Watt 1968, Goody 1977, 1986, Havelock 1986, Vernant 1965 and among the critics see Cornford 1952, who focuses on the link between traditional religion and the origin of philosophy, and Finnegan 1988, Thomas 1992, both emphasising that literacy is finally what a specific culture makes of it, i.e. that it can have very different outcomes and consequences in different cultures.
} 
Indeed, it is only by considering rational argumentations and mythical narrations as two different dialectical techniques (dialektike techne) that one can one come to terms with Plato's usage of the term "mythos". Plato sometimes uses the term in the sense of what we would call "fables" (Gorg. 523 a.2, 527a.5; Phil.14a; Phaedr. 60c.2; Resp. II 377 a.4, b.6, c.1, d5; Soph. 242c.8;), most often, in the sense of "tale" without any further connotations (Resp. I 350e.3; III 391e.12; X 621b.8; Thaet. 164d.9; Phaedr. 237a.9; 24le.8; Prot. 320.c3,7; 324d.6; 328c.3; Alc. I 123a.1; Laws III 682a.8; IV 713a.6; VIII 841 c.6; Gorg. 505c.10), but sometimes also in the expression "ton eikota mython", which designates a form of common or probable knowledge (Tim. $29 \mathrm{~d} .2 ; 59 \mathrm{c} .6 ; 68 \mathrm{~d} .2)$, and, finally, sometimes also in the sense of discourse containing a rational theory (in particular, Thaet. 156c.4; 164e.3; Resp. 376 d.9; Laws I 645b5; Tim. 69b.1). Thus not only are images such as Phedros' chariot said to be "mythoi", but also Timaeus' speech over the constitution of the world and Socrates' discourse on the education of the guardians in the Republic (Tim. 69b.1; Resp. II 376d.9). ${ }^{25}$

Plato, as a philosopher, i.e. an intellectual willing to claim the specific role that philosophy has to play, had to criticise the mythological narratives provided by poets such as Homer and Hesiod. Not by chance it is precisely in the Republic, where he presents the education that should be given to rulers-philosophers, that we find the term mythos systematically used in the sense of "fable", "untrue narrative": rulers must be philosophers, not poets (Resp. II 374a-III 417b;and also Resp. II 377a). However, it is not for their fictitiousness that the tales told by Homer and Hesiod are condemned (Resp. II 377d-378e; III 386a-392c). It is because the religious and ethical models that are transmitted through them could be morally deceptive: poets, in Plato's view, should not attribute all sorts of vices and inclinations to gods, because they must serve as moral models (idem, II 378e-379b; III $392 \mathrm{a}-\mathrm{c}$ ).

The platonic condemnation of poetry must be understood as a proposed moral emendation of traditional material, i.e. as a critique done according to a moral criterion. Otherwise one cannot understand why, after such a condemnation, Plato himself, in the same book, could possibly make such extensive use of traditional myths. Not only does Plato recognise the importance of mythical narratives for the transmission of moral models, as is shown by the fact that he recommends myths to the rulers' guardians as a

${ }^{25}$ See entry myth* in the Thesaurus graecae linguae and also Brandwood's Word Index to Plato (Brandwood 1976, 593). 
helpful means to promote social cohesion (Resp. III 414c; 415 d), but also he also uses myths as an important medium for discussing philosophical issues, such as his theory of knowledge, which could also had been presented in an argumentative form.

According to this reconstruction, one can still contend that, if not with the "birth of philosophy", it is with Aristotle that the definitive passage from mythos to logos, and the consequent association of myth with a distorted reproduction of reality, took place. Whereas up to that time, a sophos like Parmenides could still start his philosophical poem with an invocation to the Muses, with Aristotle philosophy seems to have acquired a distinguished epistemological status: philosophy became the science of first causes and principles whose results are ultimately guaranteed by logic. Whereas Plato could still intermingle dialectical argumentations and mythical narratives, Aristotle, by starting his theorising with the statement of the formal conditions of discourse and by identifying thereby a type of reasoning - the syllogism - meant to guarante the correctness of discourses, provided philosophy with a method (organon) which set it definitely a part from the stories told by myths.

All the same, not even in Aristotle there is a definitive association of myths with untrue tales. ${ }^{26}$ Aristotle explicitly claimed a specific status for philosophy. It is therefore no coincidences that, whilst Plato was the first to define his activity as "philosophia", i.e. love for the sophia (Colli1975: 13), Aristotle provided philosophy with a place and date of birth, a history, and - most importantly - a specific job. The problem then becomes to estabilish what precisely distiguishes philosophy from myth, i.e. do they depart from each other. Let us return for a moment to the passage of Metaphysics where he presents his view of the presocratics: this should provide us, if not with an accurate reconstruction of their thinking, at least with some clues about the reasons why Aristotle saw in these thinkers the "first philosophers" and, therefore, what he considers as specific to philosophy itself.

\footnotetext{
${ }^{26}$ It should here be remembered that, whereas we only possess Plato's essoteric writings, in the case of Aristotle we possess only his esoteric writings, basically notes he used for teaching. However, we know from testimonies that he wrote "platonic dialogues", all of which have been lost and which would probably reveal a more complex image of his thinking and its relationship with myth. Still it is significant that what Aristotle himself wanted to publish were precisely those "platonic" dialogues, whereas the writings known as corpus aristotelicum were the doctrines that he - as the old sophoi - communicated orally to his disciples. In fact, we cannot even say that we possess the texts of his esoteric lessons: the actual shape of the corpus aristotelicum derives from the edition of these notes made by Andronicus Rhodius, a later disciple of the Peripatetic who probably gave to the corpus a division that reflects more the first century A.C. cultural scheme than Aristotle's intentions (Adorno 1961b, 287).
} 
In this passage, Aristotle observes that, in saying that water is the principle (arche) of everything, Thales was stating something that was already contained in many myths of the origins (Met. 983b). Therefore, from the point of view of the content, Thales' theory does not contain any radical novelty. Why should we then consider such a statement as the onset of that specific discipline that is philosophy?

Aristotle does not provide any explicit answer to this question, but in the passage quoted above he continues by saying that Thales derived his theory from the observation that the nourishment of everything is humid and that even the heat comes from the humid and lives in it (Met. 983b, 30). Here, there is - at least in Aristotle's perspective - a novelty, and this concerns the method employed: no longer mythical narratives, but direct observation. Again, what was new in Thales' statement is not the content, and therefore its truth or falsehood, but the form of argumentation: whereas aquatic mythoi were narratives, this statement was presented by these thinkers - at least according to Aristotle's testimony - as the result of observations. Therefore, as already in Plato, mythos and logos were considered to differ only from the point of view of their form and not of their truth or falsity.

However, Aristotle seems to go further. Not only does he not present myth and philosophy as false and true respectively, but he also seems to recognise the links between them. In fact, in the Metaphysics, a few passages before those quoted above, we read that both myth and philosophy stem from wonder (to thaumazein) (Met. 982 b). Indeed - so continues the passage - s/he who doubts and wonders shows thereby that $\mathrm{s} / \mathrm{he}$ does not know, and this is the reason why we can say that s/he who loves the myth (o philomythos) is also somehow a philosopher (o philosophos) (Met. $982 \mathrm{~b}$ ).

Aristotle's statement that the philomythos is a philosopher is very significant. We have seen to what extent myth and philosophy differ for him. How could he say that the philomythos is also a philosopher precisely where he states that philosophy concerns the knowledge of principles and causes? One possible answer requires a further clarification of Aristotle's view of the aitiai themselves. This is a point that is hard for a modem mind to catch - used as it is to conceiving causes in the mechanicistic terms of an abstract relationship between events. However, such a view 
of causality started only with modern science, whereas antiquity understood it according to what I would call a model of production. ${ }^{27}$

Indeed, both the noun aitia, as well as the corresponding nominalised adjective aition, derive from the adjective aitios, which means "responsible of, guilty of', also in the juridical sense. Aitia thus means in the first place responsibility (Liddell, Scott, Stuart 1968:44). For instance, in order to understand Aristotle's distinction between the four types of causes - formal, material, efficient, final - we have to make recourse to the image of the artistic creation that Aristotle himself suggests in his Physics. Aristotle does not develop the concept of cause in terms of abstract relationships between events, but through the description of artistic production. In the creation of a sculpture, the formal cause is the idea of the statue, the material cause is the marble itself, whereas the efficient cause is the artist himself and the final cause is the ultimate result of the artistic creation (Physics, II, 194b ff).

Thus, since for Aristotle "to know" means "to know" why things are like this, i.e. to know their causes (Met. 983a), one must conclude that for Aristotle mythological narratives are also a form of knowledge. Indeed, inasmuch as they tell us where things come from or who has made them, they also aim at identifying causes in the sense of the Greek aitiai. This does not mean that for Aristotle there are no differences between myth and philosophy. It only means that he recognises that, by stemming both from wonder, and therefore from the recognition of a need for knowledge, they both aim at providing some kind of explanations of why things are in a certain way and not in another.

Once we have recognised that myths, too, are a form of knowledge, the next question is to spell out what kind of knowledge we are dealing with. Even a very quick look at a list of the Aristotelic concordances for the entry myth* reveals that if one wants to find out the specificity of myth it is in the ambit of poiesis that we have to search. ${ }^{28}$ Indeed, it is in the so-called Poetic that the term mythos appears most often in comparison with all the other texts, and there are thus reasons to suspect that it is here that a more systematic use of the concept is made. In the very first paragraph of the Poetic, we in fact read that the aim of this book is to look at the poetic technique

${ }^{27}$ A similar point is made by N. Abbagnano in the entry "causalită" of his Dizionario di Filosofia (Abbagnano 1971: 118), and by Pellegrin in his recent Le vocabulaire d'Aristote (Pellegrin 2001: 12). 
(téchne), i.e. at the way in which mythoi should be composed. Therefore, from the very first sentence, we know that mythoi -understood as tales and plots without any further qualification - are the constitutive elements of poetry (1447a.ff).

A few paragraphs later, when explaining the difference between poetry and history, Aristotle affirms that poiesis is a more philosophical and elevated (philosophoteron kai spoudaiteron) subject than history (1451b.6). Thus, far from associating myth with untrue speech, Aristotle places it closer to philosophy than history and seems therefore to attribute to it a capacity to catch the universal that is superior to even that of history.

Indeed, for Aristotle, given that the historian has to deal with the particular, i.e. with unrelated and dispersed facts, he will be further from the truth than the poets. That is, whereas the historian tells facts as they happened, the poet tells them as "they could have happened according to likelihood and necessity" (katà tò eikòs e tò anangkaion 1451b). Thus, in Aristotelian terms, poetry deals with something closer to the universal and is therefore a much more elevated and philosophical subject than history. ${ }^{29}$

However, the universal entailed by poetry is not the same as philosophy. Therefore, one might object that, however important, the role of myth is still limited to the ambit of the poiesis. This latter, according to a possible reading of the passages where this distinction is made, ${ }^{30}$ differs from theoresis because it "creates" its objects. This, however, does not necessarily imply that the ambit of mythos is that of arbitrariness and, as such, that it must be counterpoised to that of the logos - as we often tend to assume when talking about poetic creation. To say that poetry creates its objects does not mean that these are fictitious and exist only in the poet's head.

Let us go back to the passages in question. In both the Metaphysics and in the Topica, the expression used by Aristotle to state the differences between theoresis and poiesis is not "to create its objects" but "to have or not to have in itself the principle of movement" (e arché tes kineseos) (Topica, VI, 145a15; Met. VI, 1025, XI 1064a). According to these passages, both praxis and poiesis differ from theoresis because only

\footnotetext{
${ }^{28}$ Whereas in the Metaphysics we only have two examples for the word mythos (Delatte et al. 1984: 260), in the Poetics we have 50 (Denooz 1988,61). Analogous results can be obtained by searching or the entry myth* in the Thesaurus Graecae Linguae.

${ }^{29}$ On this point, see also the beginning of the Metaphysics and the distinction between empeira (knowledge of the particular) and techne (knowledge of the universal) (Met.980ba and $\mathrm{ff}$ ).

${ }^{30}$ See in particular Topica VI, 6, 145al. 5 and Met. VI.1, $1025 \mathrm{~b}$ and ff; XI,7,1064 a and ff.
} 
this latter deals with substances having the principle of movement in themselves. On the contrary, the arche of the poiesis is in he who produces and not in the things produced; and, Aristotle adds, this principle is either the intellect (nous) or another power (Met. 1025b 22). Similarly, in the ambit of the praxis, the arche of actions is not in the things "acted", but in the agent - so it is volition (proairesis) (Met. 1025b 22). Thus, one can conclude that in order to understand the kind of universality with which poetry deals, it is at the subject of the poiesis, or better the poietes, that we must look.

On the other hand, from these passages it also clearly emerges that, for Aristotle, poetry is far from being "imaginary" and "fanciful". Indeed, as we read in the Poetics, the essence of poetry is the mimesis, ${ }^{3 I}$ the representation of reality (Poetics, 1447a 20). This latter is not understood as the reproduction of an empirically conceived "objective" reality, but rather as mimesis of human beings who act. Mimesis is not the reproduction of what has "actually" happened, but rather of what "could have happened" according to the "likelihood and necessity" that is intrinsic to the different human characters (Poetics, 1448a).

In the following passage, Aristotle continues by saying that human beings have from childhood a genuine instinct for mimesis and that this is the way by which they first learn their lessons (ta matheseis) about the world: this learning (manthanein) gives pleasure not only to philosophers, but to all human beings, because it is in this way that we learn and infer (syllogithesthai) what each thing is (Poetics, 1448b). Mythoi thus display a kind of knowledge that is fundamentally a knowledge about human beings, about the "likelihood and necessity" intrinsic to their nature. In particular, the universality with which poetry deals is the universality that resides in knowledge about the different human characters in the plural; and, in this sense, it is therefore a plural universality.

However, as E. Auerbach has shown in his analysis of the Western evolution of the concept of mimesis, it is precisely this plurality that got lost in the passage from antiquity to modernity. Whereas both Plato and Aristotle conceived of different levels of mimesis of reality, this plurality went through a process of reductio ad unum whose

\footnotetext{
${ }^{31}$ The translation of the term "mimesis" has always been a problem for translators, because its meaning ranges from the semantic area of the term "imitation" to that of "representation". I will use the original Greek term, as far as possible.
} 
result is modern realism (Auerbach 1946). ${ }^{32}$ Whereas when we talk of "realism" in art we mean the "closeness to an empirically conceived reality", for antiquity there were different levels of "reality" to be reproduced - and it was not said that the proximity to empeiria was the criterion for what is "more real".

Indeed, it is precisely the plurality of Greek myths that is a scandal for us. We cannot but keep asking ourselves "Did Greeks really believe in their myths?"; ${ }^{33}$ and this is because we cannot come to terms with the fact that Greeks accepted a plurality of contrasting variants simply coexisting one next to the other: to our minds, this plurality should definitely have undermined the faith in their truth. This is perhaps the most conspicuous sign of a completely different attitude towards what we call "truth".

The ancient Greek word that comes closer to our word "truth" is aletheia, which, in contrast to "truth", is a privative word. Aletheia, according to its etymology, is "what is not hidden", "what is not forgotten". The term is composed by the privative prefix "alpha" plus the root lath-that forms the verb lanthano, "to remain hidden" and the composite epilanthanomai, "to forget" as well as the substantive lethe, "forgetfulness". Therefore, as Martin Heidegger first pointed out, according to its original meaning, the semantic area expressed by the Greek term aletheia is that of the "unhiddenness" and "unforgetfulness" (Heidegger1988).

Many interpreters have noticed that the world of myth, linked as it is to the archaic culture of orality, was defined by aletheia. This was conceived of not as the opposite of non-correspondence, but rather as the opposite of forgetfulness: true is what is worth preserving from oblivion (Detienne 1967; Cole 1983). The poet is he who preserves things from oblivion and thus discloses the truth. Thus, for instance, the poet Hesiod can claim to be a vehicle of aletheia. At the beginning of his Theogony, he celebrates the Muses who, he claims, to have inspired in him the voice to progressively disclose the aletheia, i.e. "the things that shall be and that were aforetime" (Theogony, vv. 1-32). On the other hand, in the same passage the Muses are said to be the vehicle of an aletheia that is plural and even goes hand in hand with falsity, as "they know how

\footnotetext{
${ }^{32}$ On the evolution of the concept of mimesis in Western culture see Auerbach 1946. Moving from Plato's discussion of the concept of mimesis and Dante's assertion that he presented the true reality in the Commedia, Auerbach reconstructs the different methods of interpreting human events in European literature. He particularly focuses on the passage from antiquity's idea of the several levels of the mimesis of reality to the modern literary realism, which implies, on the contrary, a reductio ad unum of this reality (Auerbach 1946). ${ }^{33}$ This is the illuminating title of the book of a prominent French historian (Veyne 1983). Indeed what still strikes us is precisely the plurality of stories of Greek myths, and this is the reason why we keep raising the
} 
to speak many false things as though they were true; but they know, when they will, to utter true things" (Theogony, vv. 1-32).

The archaic world of Hesiod was no longer the world of Plato and Aristotle. These latter still conceived of aletheia as the result of a process, but the road to it was no longer opened by the Muses - as it was for Hesiod and still could be for Parmenides. In Plato's dialogues, aletheia had already become the result of the dialogue of the soul with itself (Thaet. 189e-190a; Sophis. 263a, 264b). Plato states that the discourse that tells the things as they are is alethes, whereas the discourse that tells things as they are not is false (Crat. 385b). Similarly, according to Aristotle, "the false" is to negate what is and to affirm what is not, whereas "the alethes" is to affirm what is and to negate what is not (Met. IV, 7, 1011b $26 \mathrm{ff}$ ). Indeed, from this and similar passages, ${ }^{34}$ it seems that both Plato and Aristotle conceived of aletheia as correspondence to reality. Thus, if they conceive of truth as correspondence to reality, how did they conceive of this latter?

The Greeks did not even have a word that corresponds to our term "reality". We, children of the Cartesian revolution, conceive of the "real" as fundamentally opposed to what is "ideal". On the contrary, for a Greek there were only "ta onta", the things that are, or "to on", the being as expressed by the nominalised participle of the verb to be (einai). All these words come from the verb einai, whereas "reality" comes from an altogether different root. And, as we will see this different root is the sign of a different approach to the definition of "reality". ${ }^{35}$ The Greek $t a$ onta are only things inasfar as they are already conceptually clear, whereas the individual things that are just given in the experience are simply ta pragmata. Things coming under the umbrella of ta onta are the things that reveal themselves for what they are: in this sense, "to be" (einai) does not simply mean to exist, but designates a certain mode of existence. ${ }^{36}$ In other words, in the perspective of Plato and Aristotle, things that can be described as $t a$ onta are only those entities that have already revealed themselves to the understanding, whereas ta pragmata is what remains still to be determined. In this sense, ta onta are more true and more real than ta pragmata.

question, whereas on the contrary we do not ask ourselves so often - let's say - "Do Christians really believe in the history of the Bible?"

${ }^{34}$ For Plato's view of aletheia see also Soph. $262 \mathrm{e}$ and Phil. $37 \mathrm{c}$, whereas for Aristotle see also Met. V, $1024 \mathrm{~b} 5$.

${ }^{35}$ On this point see chapter 2 and chapter 3. 
This does not mean that ta pragmata are not "real". It simply means that they are less "real", or - even better - that are less "true". This brings us to Plato's understanding of the different degrees of beings (Vlastos 1965). Follwoing Plato, there is no dichotomy between being and not being, as Parmenides had thought: in contrast to Parmenides, Plato distinguishes the being in its absolute meaning, i.e. as opposed to nothingness, from the being in a relative sense, that is, from "being a certain thing" as opposed to "not being a certain thing" (Sophist 257b). Only by criticising Parmenides' view of being it becomes possible according to Plato to talk of the becoming together with the being: the becoming is not absolute negativity, but a relative one. When we make an assertion about a certain state of being, we look only at certain relationships that the things entertain with each other. Through our language, we point to only few aspects of its position within the sphere of being, because there are potentially endless divisions and communications between the things, and our language can only express parts of it each time.

Plato's theory of ideas confirms this reading. Inasmuch as they present the being in its clearest way, ideas are being that truly is. ${ }^{37}$ Ideas constitute the maximum form of reality, since compared with them sensitive reality is just a pallid imitation. If we want to talk of Plato's conception of "reality", then this latter must be understood as the opposite of appearance, because ideas are being that remains in the instability of becoming, and in this sense ideas themselves must account for appearances (Moravcsik 1992). ${ }^{38}$ The task of philosophy, understood as dialectics, is to show the divisions and correlation of being (to on) in order to reconstruct the interrelation between ideas (eidos, idea). These latter, far from being purely mental contents as we, since Descartes, have started to understand them, were at the same time thought and reality. ${ }^{39}$ Thus, the "birth of philosophy" cannot be interpreted with Vernant as the rise of "positive thought" since not even in Aristotle can knowledge be said to be the

\footnotetext{
${ }^{36}$ The term ousia too, far from designating what we mean by "reality", indicated being in the sense of the substance -also in the sense of material substances (Liddell \& Scott 1968: 1274).

${ }^{37}$ On Plato's theory of ideas see Ross 1951, whereas on the platonic idea of different levels of reality see Vlastos 1965. On the way in which, according to Plato, "reality" in this sense accounts for appearances see Moravcsik's seminal work on Platonism (Moravcsik 1992)

${ }^{38}$ This view of "reality" as opposed to "appearances" went on to become extremely influential in subsequent philosophical thinking. Examples of this view can still be found today. For instance, according to Audi's Cambridge Dictionary of Philosophy, " Reality: in standard philosophical usage, how things are, in contrast to their mere appearance" (Audi 1999: 775)

${ }^{39}$ See entry "Idee" in the Historisches Wönerbuch der Philosophie (Neumann 1972: 56) and also "Idea" in the Abbagnano's Dizionario di filosofia (Abbagnano 1971: 450).
} 
discovery on the part of a "thinking" subject of a given "physical reality". The idea of a hiatus between the knowing subject and the known object seems to be alien to antiquity. Knowledge, until Aristotle, was istead conceived as a passive process because it is being that manifests itself in physis. In Aristotle's terms, for instance, the knowing subject cannot be separated from the object, because this latter immediately "affects" the soul (De Interpretatione 16a3).

Aristotle does follow his master Plato in both his view of the truth and in the idea of "different degrees of reality". Aristotle also states that aletheia and falsity pertain to the ambit of unification and separation (Met. IV 1011b26, V 1024b25, De Interpretatione, 16a9). Moreover, he also conceived of what we call "reality" in terms of different degrees. He even states an explicit correspondence between the ideas of degrees of reality and of degrees of truth. According to what we read in his Metaphysics:

"Now every thing through which a common quality is communicated to other things is itself of all those things in the highest degree possessed of that quality (e.g. fire is hottest, because it is the cause of heat in everything else); hence that also is most true which causes all subsequent things to be true. Therefore in every case the first principles of things must necessarily be true above everything else--since they are not merely sometimes true, nor is anything the cause of their existence, but they are the cause of the existence of other things,--and so as each thing is in respect of existence, so it is in respect of truth" (Met.993b).

Thus according to Aristotle, each thing possesses as much being as it has truth. Aristotle, unlike Plato, conceived of being as a synolon of matter (ule) and ideasforms (eidos-morphe) and he conceived of becoming as the actualisation (entelecheia) of a being which has it in potency (dynamis) (see in particular, Physics, II). The two theories are also combined for, while the matter is the material cause of the becoming and its potency, the form is the formal and final cause as well as the principle of the actualisation (entelecheia). Now, given that what is in potency can pass into act only under the effect of something which is already in act, this made it necessary for Aristotle to postulate the existence of a being that is already in act and, following the chain of dynamis and entelecheia, we therefore arrive at the postulation of a being that is always in act, namely god itself (Met. XII). 
The Greek term entelecheia comes from the adjective enteles which means "complete, perfect". Entelecheia thus, properly speaking, designates a "full, complete reality" as opposed to what has it only potentially (Liddell, Scott, Stuart 1968: 575). And, as we will see, the Latin term "realitas" was used as a synonym of "perfection" (Courtine $1992 \mathrm{a}, 1992 \mathrm{~b}$ ) - a view which is understandable only by moving from the ancient view of the different degrees of "what is real". ${ }^{40}$

To conclude, it is only within such a view of being and truth that the pluralistic Greek myth was possible. As Paul Veyne maintained, a plurality of programs of truth existed for the Ancient Greeks: it is because of this plurality that one could believe in both the "legendary" world of myth and the truth of everyday "reality" (Veyne 1983). What appears to us as an untenable contradiction between a plurality of narratives was no problem for them - and not even for Aristotle, the father of the principle of non-contradiction. Indeed, when stating this principle Aristotle was very cautious and added an extremely important qualification to this principle: "It is impossible for the same attribute at once (hama) to belong and not to belong to the same thing and in the same relation (kai kata to hauto)" (Met. IV 1005b). The importance of this apparently insignificant adverb "hama" can never be underlined enough.

Let me finish with a story. The Ethiopic people of Dorzés believe that leopards are Christian animals and that they will therefore respect the precepts of the Copt church and, in particular, fasting onWednesdays and Fridays ${ }^{41}$. All the same, leopards being very dangerous for their livestock, they keep guard over their animals even on Wednesdays and Fridays. They see no contradiction between the two beliefs, that leopards fast on those days and that they might attack their livestock in those days. In one case, it is the truth of their tradition that is at stake; in the other is what they learnt through experience. Clearly, for them, it is a different truth that is at stake each time. The emergence of the idea of myth as "purely fictitious, untrue tale" from which we departed is the sign that this plurality has now been lost.

\footnotetext{
${ }^{40}$ On this point see also chapter 2 and chapter 3.

${ }^{41}$ The story is told at the beginning of an essay on the concept of truth (Messeri 1997: 1).
} 


\section{THE BIBLOS AND THE DIALECTIC OF THE SACRED LOGOS}

While the Hellenistic epoch was still capable of producing an intellectual and artistic movement such as that of Aetiology, this would have been impossible in the Christian epoch. The aim of aetiological poetry was to narrate the origins of things by re-elaborating mythological material. It was not only a manifestation of the Alexandrian taste for erudition, willing to recover ancient traditions, but it was also an expression of the desire to provide a meaning for features and aspects of ordinary life a need that became particularly acute as the system of the polis declined. Aetiological poetry, as represented by Callimachus' Aitia, aimed at overcoming the sense of displacement produced by such a decline, and it did it by re-elaborating the contingency of reality through the identification of the aitia of things - where these latter are to be understood in the sense of the Greek aitia. ${ }^{42}$ This approach entails a relationship with myth and its plurality that would have been impossible in a Christian worldview. Why?

In order to understand what happened to the concept of myth, we have to look at the transformation of the other side of the dichotomy: the logos. This is because it was with Christendom that it was given a completely new meaning. The genealogy of myth begins with the term logos originally meaning simply "word", "discourse" and being thus almost a synonym of mythos. Around the fifth century $\mathrm{BC}$, the term logos began to occupy the semantic space of mythos, adding to it the connotation implied by

${ }^{42}$ Aitia is the title of Callimachus' collection of elegies. The object of these elegies was the narration of tales explaining the origins of rituals, fests and institutions. The text of the Aitia got lost during the Middle Ages. We possess only a small number of papyruses coming from Greek-Roman Egypt, whereby it was possible to reconstruct the original design together with part of the text (Callimachus 1949,52). 
the verb legein, "to say" but also "to count" and "to enumerate". While mythos started to be used in the sense of "popular tale", the term logos acquired further connotations such as "measure", "esteem", "proportion", "explanation" and "definition". All these meanings were nevertheless still part of the primary meaning of the term: "calculus", "discourse" and "reasoning". In this sense logos did not, however, designate a "mere discourse" as we understand it; it rather meant at the same time "discourse over" and "structure of reality". It was used in this sense by Heraklitus (Diels \& Kranz 1951, 114) and through Plato (see for instance Thaet. 206d) and the stoics, it reached the neoplatonists (Abbagnano 1971: 547).

With Christendom the term acquired a completely new meaning, a meaning that, apparently in continuity with the past, had in fact a revolutionary impact.

"At the beginning there was the logos, the logos was with God, and the logos was God. He was with God in the beginning" (John, I, 1).

The overwhelming power of the transformation brought about by Christendom is inscribed in this incipit of the Gospel according to Saint John. Here the logos is not only the structure of being: logos is the Word of God, a Word which has been written in the will of God since the origin of times. And, as we will see, when the logos became the word of God, a word that is written, and that is written in a definitive form because it is the sacred Will of God, there is no more space for the recognition of myth.

Logos is the term used by Hellenised Jews in their translation of the Old Testament to render the Hebraic term dabhar, the scriptural name for the creative word of God. ${ }^{43}$ By comparing the incipit of the Biblos, the "Book", with Hesiod's Theogony, which systematised Ancient Greek mythical material, a triplex level of rupture can be captured.

"At the beginning, God created the heavens and the earth" (Genesis, I, 1).

\footnotetext{
43 As well known, Jews did not accept the so-called "Bible of the Seventy", i.e. the Greek translation of the Old Testament made around II century BC in Alexandria by some Hellenised Jews of the Diaspora. This text, encompassing both writings excluded by the Jews' canon and others directly written in Greek, reflects the attempt by Hellenised Jews to reconcile Hebraism with the Greek tradition. However, after the destruction of the temple of Jerusalem ( $70 \mathrm{AC}$ ). Jews felt there to be a strong incompatibility between Hebraism and the Greek-Roman culture. Whereas they returned to the original source of the Hebraic tradition and therefore rejected the Bible of the Seventy, this latter became the Old Testament of the Christians.
} 
Whereas at the origins of the world, according to Hesiod, there was chaos (Hesiod, Theogony, 116), which was only later mitigated by the division of power among different gods (idem, $110 \mathrm{ff}$ ), in the Genesis the world presents itself as a cosmos from the very beginning. Whilst Greek gods divided a world, which already existed, among themselves, the world of the Christians is a world created by God himself.

"And God said: « let there be light » and there was light. God saw that the light was good, and he separated the light from the darkness. God called the light «day» and the darkness he called «night». And there was evening, and there was morning - the first day" (Genesis, I, 3).

The text carries on by describing the way in which all things were created, and the model is always the same: it is by naming things through his word (logos) that God created them. The rupture could not be greater. Whereas Hesiod's Gods divided among them an already existing world, the world of the Christian is a world created $e x$ nihilo. Whereas the conception of a creation ex nihilo was completely alien to Hesiod's polytheistic universe, the world of the Genesis can be created ex nihilo because it is the world of an omnipotent God.

The omnipotence of the unique God is thus the omnipotence of his Word (logos) - in the singular. The world of the Genesis is thus not only created ex nihilo: it is created through the Word of God. The Greek logos, discourse, structure of a polytheistic world became here the Creative Word of the unique God. If Hesiod's mythical universe reflects the human need to have a world ordered through a plurality of narratives corresponding to a plurality of gods, in a Christian worldview there is no need - but also no space - for any further narratives besides that of the Sacred Word of God, because everything is provided with a meaning from its very beginning. In the idea of the Sacred History there is, therefore, an absolute pretension: no further narrative is needed because the logos was there from the beginning so that from their very coming into being all things were endowed with a meaning.

We move here to another point - the different conceptions of time expressed in the Old Testament and Hesiod's incipit, respectively. The Christian conception of history differs from the ancient one because it is a linear conception, whereas Greek 
antiquity had a cyclical view of historical time. ${ }^{44}$ The Ancients Greeks, as most of the ancient peoples, conceived of time as the continual return of the same sequences of time or epochs. This is a view linked to the cyclic rhythms of nature: becoming in nature is characterised precisely by the continuing retum of the same phases. Whilst according to this view there is no proper evolution in history, according to the Christian view history itself has a beginning and a telos.

The three revealed monotheist religions share this linear view of history. In the first place because for all of them the world is created, it is created by God and, at the very same moment, it is situated in a linear flux of time and provided thereby with a telos. This latter corresponds with the day of the final judgement: the coming of the Messiah for Hebraism, the return of the judging Christ for Christendom and the yawm ad-deen, literally "the day of the religion", for Islam. The three great world monotheisms share thus a triplex schema "creation - revelation - final judgement": notwithstanding the huge differences among them, they all share this schema and the linear view of time that it implies.

In particular, for Christians, the first great eschatological event is represented by the coming of Christ: this is the first defeat of $\sin$ and death. Through the mystery of the incarnation, passion and resurrection of Christ, time is given a further connotation. The coming of Christ represents the beginning of time in a more human sense, because it is only after the liberation from the original sin that time - understood as sequence of occasions for the exercise of human freedom - began. Notwithstanding the endless theological disputes on this issue, Christendom will never go beyond the eschatological schema of the Old Testament and the omnipotence of God that it exhibits.

As emphasised by Hans Blumenberg in his Arbeit am Mythos, the difference between Greek antiquity and Christendom is also reflected in their different attitudes towards chronology: in Greek myths there is no proper chronology, but rather a series of sequences; Christians, on the other hands, were obsessed by chronology. Inasmuch as time is divinised it also acquired a completely new meaning. And this is the reason why - as Blumenberg puts it - negligence in chronologising is unforgivable in dogmatic observance (Blumenberg 1979, I, 2).

\footnotetext{
${ }^{44}$ Many commentators have raised this point. See for instance Löwith 1949, Eliade 1954. On the Greeks' equivalent to the concept of progress, see Meier 1980.
} 
If the logos defines the beginning and the end of time, then the kind of truth that the logos itself embodies needs and can be situated in a linear flux of time. Hesiod's stories are thus replaced by a single History. We are moving here to a third level of rupture. Whilst a feature of myth is its continual re-transmission and reelaboration, the "truth revealed" in the Holy History presents itself as unique. Once the truth is revealed and it is revealed in a Holy History, there is only the need to interpret it. The biblical saying "so it is written" represents the funeral epitaph of ancient myth, whose essence was the possibility of a plurality of stories.

Indeed, there is something in the idea of a "religion of the Book" that is fundamentally hostile to myth (Gadamer 1981b). And this is precisely the fact that when the written word became the means through which God reveals himself and reveals himself as Unique God, the biblos became the bearer of an absolute pretension to truth that was alien to myth. We have above seen that Ancient Greeks conceived of the truth (aletheia) as the progressive uncovering of being; the idea of a religion of the Sacred Scriptures instead implies that truth is revealed and is revealed in the definitive form of uniqueness.

All the three revealed monotheistic religions are religions of the "Book" and they all reflect this absolute pretension to truth. They all share the Exodus' commandment: "You will have no other gods before me" (Exodus, 20, 3). ${ }^{45}$ The sacred logos is not only the creative Word of God, but is also, at the same time, the Word through which God reveals his Will: the logos is the Word of God and thus the Law. Even if certain forms of monotheism have accentuated the aspect of Law more than others, it still remains that this absolute pretension represents a revolution that is common to the three monotheistic religions.

There is a clear symmetry between this God, the absolute creator and lawgiver, and the forms of political domination in which these ideas have been affirmed. Recently, the idea of a "political theology" has been advanced in order to emphasise this link (Assmann 2000). According to Assmann, the belief in God as absolute law-giver is a political theology: by this he means that the relationship between the religious and the political order should not be read as dualism or as the

${ }^{45}$ Monotheism was already present in other religious experiences. For instance, famous is the attempt by Amenophy the Fourth in the Egypt of the XVIII dynasty (XIV sec B.C. ca) to reform the Egyptian religion in a monotheistic sense. All the same, what we are interested in is not an exhaustive reconstruction of the 
subordination of one to the other but rather as a relationship of Repräsentation (Assmann 2000: 28). By reversing the thesis of Schmitt, ${ }^{46}$ Assman has shown how the religious concepts developed in Ancient Egypt, Israel and Europe were originally political concept (Assmann 2000). The connexion between domination (Herrschaft) and the sacred (das Heil) does not only go in the direction of the instrumental use of the sacred in order to uphold political domination, but also the other way round: it is the political institutions that, by shaping the contexts help to create certain attitudes towards the world. The sacred does not only produce domination, but is at the same time its result.

To put it in Hegel's words, only in the unhappy times of generalised fear and serfdom could monotheism have established and asserted itself (Phänomenologie, part B. Freiheit des Selbstbewusstseins). The religious consciousness of monotheism is a fundamentally unhappy consciousness (Unglückliches Bewusstsein), because it alienates all freedom from itself by projecting it into a transcendent immutable (Unwandelbare) and thus remains entrapped in its self-created serfdom. The world of the unique omnipotent God is thus the religious counterpart of a political alienation. The omnipotence of the dominus is the impotence of its servi. The struggle between the dominus and its servi takes thus the form of an alienating scission of the consciousness in itself (die Verdopplung des Selbstbewusstseins in sich selbst), where the essence (das Wesen) is projected into the Immutable (das Unwandelbare), whereas what remains for the conscience is only what is inessential (Das Unwesentliche) (Phänomenologie, part B. Freiheit des Selbstbewusstseins).

Such a process of emptying out of the world in favour of a transcendent being, bearer of an absolute pretension is clearely fundamentally hostile to the polytheism of the myth. In the world of the Unique God, myths could not but be perceived as blasphemy. "Mythoi", originally simply "words, tales", could thus be relegated to the idea of "fanciful", "imaginary" tales that, far from containing any kind of truth, are deceitful and dangerous for the salvation of the soul. Given that all

\footnotetext{
history of myth, but rather a much less ambitious reconstruction of one of its possible genelogy. And from this point of view, it is only with Hebraism that monotheism came to its fullest expression

${ }^{46}$ According to Schmitt, "all significant concepts of modem theory of the state are secularised theological concepts not only because of their historical development - in which they were transferred from theology to the theory of the state, whereby , for example , the omnipotent God became the omnipotent lawgiver - but also because of the systematic structure" (Schmitt 1922. III). Schmitt's preferred examples are thus the parallel between God and the absolute lawgiver and the idea of exception that he sees as analogous in jurisprudence to the miracle in theology (Schmitt 1922, III).
} 
pretensions to truth were advanced by the sacred logos, the Word of God, no space was left for myth. It was then that the negative connotation of "myth" was first established: the myth became all that the sacred logos, the Unique Truth, is not - the enemy to defy, the pagan to be converted.

Certainly the revealed Word of God must also be interpreted. Both a Jew and - to some extent - a Protestant would thus, for instance, agree that, interpretations of the Sacred Scriptures being endless, the Sacred Scriptures admit of a plurality within themselves. ${ }^{47}$ However, even if one agrees on the openness of possible interpretations, it still remains that this plurality is only admitted as that of mere interpretations. As Castoriadis has pointed out, "interpretations" and "commentaries" are the means employed by world religions in order to process and assimilate the new: once a closure of meaning has been operated, "interpretations" become the means through which the new can be subjected to a fictitious but efficient reductio and the closure of meaning thus perpetuated whilst apparently accepting the new (Castoriadis 1988: 153).

In other words, interpretations are provided within a general plot that is already given and thus presented as the revealed and unique sacred truth. The absoluteness of the pretension to truth already defines the range of possibilities. On the contrary, the plurality of myth is not only a plurality of interpretations: it is also a plurality of Gods. First, it is a plurality of variants within a mythologem, where each variant presents itself as legitimate in its own right: there is no possible contradiction among the different variants of a myth because no superior criterion is given. Rather, each variant finds in itself its ratio essendi. Second, the plurality entailed by myth is not only a plurality of variants within the same narrative plot, but also a plurality of mythologems, i.e. a plurality of different narrative cores. Each mythologem is legitimate in its own right because each god has his myth and none of these gods aspire to being a unique God. ${ }^{48}$

Thus, the idea of myth implies the recognition of a plurality of truths that was denied by the idea of a Holy History as such. A comparison between Hesiod's

\footnotetext{
${ }^{47}$ The creative force of Hebraism is expressed by the fact that the biblical comment (midrash) is composed by both halakhah, which is the part that interprets the Torah by actualising its precepts, but also by the haggadah, the exegetic tradition composed by tales inspired by the biblical text and aimed at clarifying its meaning.

${ }^{48}$ On polytheism of myth, see Schmitt (1923) and also chapter 10 . In his analysis of the myth of Prometheus, Blumenberg speaks of a conflict between different gods (Blumenberg 1979). The idea of the polytheism of myth was then developed by Odo Marquard who, in the context of the divided Germany of the 1970s, used
} 
Theogony and the Exodus can further clarify the point. As we have seen, in the proemion to his Theogony, Hesiod starts with an invocation to the Muses, which are said to have breathed a divine voice into the poet to celebrate things that shall be and things that were a foretime (Theogony, 30ff). At the same time the Muses present themselves as those who "know how to speak many false things as though they were true but also know, when we will, to utter true things" (Theogony, $26 \mathrm{ff}$ ). Thus, Muses are introduced as the source of a divine knowledge, but at the same this knowledge is intrinsically plural not only because the Muses are many, but also because they tell "true things" as well as "false things as though they were true".

On the contrary, the God of monotheism is a God who could never tell false things, because this would contradict his absolute pretension to truth. Thus, whereas Hesiod's Muses appear to the poet saying who they are, the God of the Exodus presents himself to Moses with a tautology: "I am he who I am" (Exodus, 3, 13). The pretension to truth can be absolute only because it is based on a tautology: God is not defined by any other Word than His own. God is causa sui and has thus no other ratio essendi than Himself. Precisely because it is tautological, the logos is sacred and thus unique and needs no other Words. This is, finally, the fundament on which its Commandment is based: "you will not have any other gods before me" (Exodus, 20, 3).

Nor does the Euangelion mitigate this absoluteness. On the contrary, the New Alliance announced by the Gospel (Euangelion) reinforced this pretension to truth by adding a new dimension to it. Now the logos is not only the creative Word of God and the word with which God reveals his will (the Law): it is now the living Christ, the God that became flesh. The incipit of John's gospel quoted at the beginning continues with the following words: "The logos became flesh and lived for a while among us. We have seen his glory, the glory of the One and only Son, who came from the Father, full of grace and truth" (John I, 14). Christendom legitimises itself as the fullest revelation of the nature of the logos: whereas the Old Testament has already known the creative Word of God (Genesis, I, 3ff; Isaiah 40, 8; 44, 24-28; 48, 13; Psalms 33, 6) and its revealing mission (Psalms 107, 20;147, 15-18), it is the task of the Euangelion to complete the revelation by announcing the personal nature of the Sacred Word (logos).

the concept of polytheism of myth in order to oppose it to the "monomythie" of the great narrative of emancipation (Marquard 1979). 
The words of Christ "I am the way and the truth and the life" (John XIV, 6) thus closed the circle opened by the creation-revelation of the Old Testament. As such they further justify a process of theologisation of the truth. It is to these words that Saint Augustine referred when stating that the truth is God himself. This identification is developed in reference to Saint John's passage quoted above. Truth for Augustine coincides with God, because the "truth" is the source that we must necessarily admit in order to understand the condition of true things: the truth is the measure, so that the true thing is true because it is measured by it (Confessiones, VII, 10-11; 17). Analogously, according to Saint Anselm, God as the "summa veritas" is the source of each single truth. The influence of Augustine is clear. Recovering, again thorough Augustine, the neoplatonic interpretation of Platonic ideas as the thoughts of God, Anselm states that things are true inasmuch as they are agree with their ideas, i.e. with the thoughts with which God has created them: "there is truth in the essence of the things that are, because they are as they are in the supreme truth (summa veritas)" (De veritate, cap. 7).

God as the measure of truth is also the measure for what is real. God himself is the ens realissimum, the presupposition necessary in order to explain the existence of reality. In what sense can God be said to be the ens realissimum? What "reality" are we referring to? We have seen that Greek antiquity did not have a word corresponding to our word "reality". Indeed, it is in the Latin Middle Ages that the word "realitas" was first coined. The first attested occurrence of the term appeared in late Scholasticism (Courtine 1992 a). However, the term "realitas" at this stage refers primarily to the substantive "res" in its widest meaning and designates what makes a res to be what it is, i.e. its essentia, or even better, the essentialitas of each "res" as such (Courtine 1992 a, b).

In this sense, "realitas" is identified with the formalitas and "realismus" was indeed said to be that conception according to which these formalitates exist as universals in re. Thus, "realismus" as a philosophical position sustaining the existence of universals in re was opposed to nominalismus, i.e. the view asserting that they only exist in voce. The terms "realismus" therefore originally meant a conception that is almost the opposite of what it came to mean in modern philosophical usage at least after Kant. Whereas this latter understood "realism" as the opposite of "idealism", the 
original medieval term "realismus" designated a position that is in fact closer to what Kant would call "idealism" (Hoffmann et al. 1992). ${ }^{49}$

The term "realitas" thus designated a semantic area close to what we call "perfection" - where "perfectio" must be understood in its etymological meaning of a "complete being". We are now used to a completely different meaning and have therefore forgotten that in medieval sources the word "realitas" meant something else (Courtine 1992 a,b). Traces of this use can, indeed, still be found in the work by modern philosophers. Descartes for instance uses the expression "realitas sive perfectio in aliqua re" (Med. 3, Ax.3, 165). Spinoza, on the other hand, explicitly states in the Second Part of his Ethics that "per realitatem et perfectionem idem intelligo" (Spinoza, Et. II, def. VI).

We must take this identification of the "realitas" with the "perfectio" seriously. This does not mean that those who used this expression did not believe in the reality of "this world" - which is certainly not perfect. It simply indicated that they conceived of "this world" as only one possible level of "reality". In Scholasticism, the concept that was in fact associated with it was that of "analogy". The being of the creature is neither identical with the being of God nor completely alien to it: it is analogical, i.e. similar, but different. As Thomas Aquinas put it, only God has being as His essence, whereas the creatures have being only for participation; in this they are similar to God, who is the first principle of being, but for the same reason, God is incommensurable with them, and can therefore be the subject of only an analogical predication (Summa theologiae, I, q. 4, a.3). ${ }^{50}$

The concept of realitas as perfectio thus suggests a view of "reality" which, like the Greek to on, contemplates different degrees of reality but within which, in contrast to it, God Himself, the ens perfectissimum by definition, works as the ordering ontological criterion. The omnipotent God creator of being, and thus the measure of truth, is also the ens realissimum and thus a measure for what is "real": according to this position, the closer to God things are, the more they are real.

\footnotetext{
${ }^{49}$ On this point see also the entry on "realismo" in Abbagnano 1971, 732.

${ }^{\text {so }}$ When Duns Scoto criticises this view by saying that omne ens habet aliquod esse proprium, he aimed at reconstructing the unity of being as common to all that exists. He did this because he thought that it would have been impossible otherwise to know the true nature of God, but by recognising the autonomy of each single individual being he thereby opened a way that went beyond the typically medieval view.
} 
Traces of this approach to truth and reality can still be found in some fragments of the medieval imaginary. ${ }^{51}$ Cosmology was particularly crucial from this point of view, conveying images of the universe that were echoed in the numerous astrological and magical handbooks and practices as well as in the representations of the afterlife used in sermons and the curing of souls.

As Pierre Duhem observed, commentaries to the Genesis, which functioned as the bases for early medieval cosmology, were not writings directed towards specialists: they addressed their views to the Christian masses, who were expected to progress not in the studying of astronomy but, rather, on the road to salvation (Duhem 1965: 396). Whereas some of these commentaries, following Origen, tried to reconcile the Scriptures with previous cosmological speculation, others proposed an approach that was characterised by a strict adhesion to the text of the Sacred Scriptures. These latter were also considered to contain all the truths regarding the constitution of the natural world: the world was perceived as a second "book written by God" and was therefore interpreted as sacramentum salutaris allegoriae and then read through the biblical exegesis itself (Duhem 1965: 396ff).

Thus, for instance, in the VI century, Cosmas Indicopleustes, a pious Christian wrote a very influential Christian Topography of the Universe, demonstrated through the Sacred Scriptures and whose truth Christians cannot question (Cosmas 1897). Mixing of the ancient doctrines re-elaborated by Fathers of the Church and the more recent biblical exegesis, Cosmas affirmed that the right model for the universe was the tabernacle constructed by Moses. The earth is flat and the stars are transported by angels. And this was, thus, the universe depicted in churches, books and representations of afterlife for a long time. Around the XI century, however, a new series of previously unknown Greek and Arabic classics were translated into Latin. The Platonic Timaeus, known in its first part and accompanied with a comment by Calcidius (IV century), together with Ptolemy, translated from the Arabic, generated a new view that, on the basis of a rediscovered Aristotle's Physics, ${ }^{52}$ went on to prevail for centuries.

\footnotetext{
${ }^{51}$ On the notion of imaginary, see in particular Castoriadis 1975 and Chapter 10.

52 Whereas Plato was known to the Middle Ages essentially through the testimony of Augustine, Aristotle was know only through Boetius' translation and comments of and on his De interpretatione and Categoriae. The physical and metaphysical writings were translated only in the XII century (the ethical, political and thetorical even later). Initially seen with suspect for their idea of natural necessity ( which was considered as a possible threat to the dogma of God's omnipotence), Aristotle's writings were later on reconciled with
} 
Aristotle conceived of the world in purely qualitative terms, that is to say he divided the universe into several parts constituted by different qualities corresponding to different degrees of perfection. In this universe there is, on the one hand, the sublunar world, whose elements earth, water, air and fire, move according to a linear movement, which is imperfect. On the other, beyond the sky of the moon, there are the skies, conceived as spheres, of the sun and the other planets, which are made by an incorruptible substance (ether) and which move according to a circular movement, which is perfect. Beyond the sphere of the fixed stars, which is the limit of the Aristotelic universe, there is the first immovable motor, the first principle of everything, which is non-material - because matter is subject to corruption, pure thought of thought. Imperfection on the one hand, all the perfection culminating in an immovable motor on the other: the Church liked this cosmology. And its agreement with the dogmas of faith certainly helps to explain its persistence.

Supported by the authority of the church, the Aristotelic-Ptolemaic cosmology dominated for centuries. This also means that for centuries people were exposed to this particular image of the universe: they saw such a world in churches, in the paintings adorning them, in astrological and magical handbooks, in sermons, and in the various representations of the afterlife. This was a world constructed according to a multilevel scheme, where to each level corresponds a further grade of perfection. The culminating point was obviously the being always in act, the perfect being, or ens realissimum. This is not to say that people did not believe in what we can call the "extemal empirical reality", but only that this latter was thought of as only one level of reality and, possibly, as the level entailing the lowest degree of perfection. ${ }^{53}$

Medieval figurative art is quite often characterised as "non-realist", this meaning that medieval painters did not paint bodies and objects as they are "in reality", i.e. as we perceive of them through our senses. However, the point is not that these paintings are not "realistic": it is, rather, that "realitas" was itself perceived differently. It is not that medieval painters could not see that their paintings did not reflect the way in which things appear through senses. The way in which things appear to our sensitive experience was on the contrary not so important for a medieval painter. There was no

Christendom particularly thanks to the thinking of Thomas Aquinas, who made Aristotle's natural necessity into an instrument to demonstrate the truth of faith. 
point in depicting bodies and objects in this way for him. Only together with a new Weltanschauung, where not God but the human being is the measure of everything, then the way in which things appear to our sensitive experience would be given a new centrality (Geertz 1983, 5).

Thus, whereas the myth could not be encompassed within such a Christian worldview because of its subversive plurality of histories, Christendom was still able to negotiate with ratio inasfar as this was accepted as being a means to reach the revealed truth. Myth was instead subjected to a fundamentally hostile attittude. At first sight, the attitude of the Christendom towards the mythological heritage might appear to be ambiguous rather than outrightly hostile, because Christendom itself made recourse to it to such a great extent. However, even this ambiguity reflects a fundamentally negative attitude, which transpires even when previous mythological narratives were apparently "admitted". In fact, for all the reasons we have seen above, myth could not be recognised in its own right within a Christian worldview. On the contrary, myths were "christianised", through both the reductio ad unum of their truth and the conversion of their content. This is to say, they were not recognised because, even when apparently "recovered", their plurality was denied. Ancient myths were either deleted by material oblivion or, when possible, they were read as involucra, integumenta of the revealed truth, i.e. read as an anticipation of it.

Among the hermeneutical devices that led to this reductio ad unum, two have been particularly efficient. Both of them have their origins in the biblical exegesis. One of the fundamental problems for the Christians of the origins was indeed how to interpret the stories of the Old Testament. Among the Fathers of the Church, in particular, two fundamental approaches were elaborated. The first, recommended by Origen, was more "spiritualist" and proposed interpreting these stories as allegories, i.e. as stories or imagines referring to some hidden and remote meaning that was different from the literal one. In this perspective, the literal meaning was dissolved into a spiritual one.

The second more "realistic" approach was proposed by Tertullian and is constructed around the notion of "figura futurorum". ${ }^{44}$ Tertullian pointed to the

\footnotetext{
${ }^{53}$ Criticism of this view was raised in particular within the mendicant orders. According to Saint Francis, for instance, it is each single creature that, having been created by God himself, carries signs of its perfection. However this was the view of only a minority and it was opposed for long time for its political implications. ${ }^{54}$ See in particular "Figura" in Auerbach 1938.
} 
historical truth of the tales of the Old Testament - that was, on the contrary, completely ignored by the allegorical reading by Origen. In Tertullian's view, Moses actually went through the desert, and this is a historical truth that must be preserved in the exegesis. At the same time, Moses leading the Jews out of the desert is read as the figura or "real prophecy" of the coming of Christ and the liberation of souls from sin. Both are historical events, Moses and Christ, but the first is a figura futurorum, an "umbra" or "imago", that finds its realisation in the future coming of Christ, which is, in fact, its "veritas".

Figural interpretation was very influential in Latin Middle Ages, as a consequence in particular of Augustine's authority. As Erich Auerbach points out, it was Augustine who most emphatically recommended it for the sermon and the mission of evangelisation; furthermore he gave examples of how to further develop it: Noah's ark is "prefiguratio Ecclesiae" (De Civ.15,27), Moses is in different ways "figura Christi" (De Civ. 10, 6 or 18,11); Aaron's "sacerdotium is "umbra et figura aeterni sacerdotii" (De Civ. 17,6), and so on (Auerbach 1938).

The two hermeneutical devices, allegorical and figural reading, enabled the whole history to be read as a history of salvation: each event, each narrative can be read through them either as allegorical involucra of the superior truth of salvation or as its "real prophecy", which in a chain of successive figurae futurorum, will find its final truth at the end of time and final triumph of the judging God. The figural interpretation could thus be used as the basis for the interpretation of history: if the world is a liber, a book created by the Word of God, than it is natural to interpret it with the same means used to interpret the Sacred Scriptures. The two hermeneutical devices described above were particularly helpful to this process, then.

Through such devices, the pagan world of myth, even when apparently recovered, was in fact reduced to a unique truth and thus denied in its pluralistic nature. Noteworthy examples of this can be seen in Dante's Divina Commedia. This summa of both the ideological and imaginative medieval apparatus is full of figures drawn from the pagan world. This seems to be the obvious consequence of the fact that the object of this sacrato poema (Paradiso, XXV, 1) is the description of Dante's voyage in the afterlife and his visio of the status animarum post mortem (Lettera a Cangrande della 
Scala). ${ }^{55}$ Pagans do not only appear among the damned. Virgil is Dante's guide, and this has always been explained by referring to an allegorical reading of Virgil, as an allegory of human reason: Virgil who cannot accompany Dante in the Paradise would then be the allegory of the impossibility of human reason to go beyond certain limits, much as Beatrice, who comes to Dante's aid, would be the allegory of divine grace. But what about other pagan figures such as Cato or Ulysses - just to take only a few examples?

Cato, pagan and guilty of one of the most horrible sins for Christians, i.e. suicide (Purgatorio, I, 70-75), is nothing less than the guardian of Purgatory, the realm where souls can gain the freedom from sin that they have lost. This is possible because the story of Cato is not denied in its historical truth, but the historical Cato, who committed suicide for the sake of political freedom, is read as the figura of the Cato that is here presented as guardian of Purgatory (Auerbach 1938). Only inasmuch the political freedom for the sake of which he committed suicide can be read as "umbra futurorum" of Christian freedom, can Cato represent the guardian of Purgatory, i.e. of the place where the soul can free itself from the serfdom of $\sin$.

Dante's recovery of the myth of Ulysses should be interpreted in a similar vein. The story of the Ulysses, burnt with Diomede in the XXVII Canto of the Inferno, is conceived by Dante as the fullest realisation of the Homeric Ulysses: the pagan Ulysses is only a figura o umbra of its fullest Christian truth. Thus, the Ulysses who is here burning is not only condemned to be burnt eternally for the fraud of the Trojan horse, but, in Dante's account of this myth, he is swallowed up by the sea for having dared to navigate beyond Hercules' Columns. Thus, Dante's Ulysses is neither a recovery of Homer's mythical character nor one of the possible variants of a variously reinterpreted myth: it is the figura of the human reason and its incapacity to go beyond the limits imposed by God.

The point is not that Dante rejected Homer's version of the story of Ulysses, or, even less, denied the historical truth of Cato's story. It is only that these events are subordinated in their fullest realisation to the coming of Christ. Analogously, it is not that Christendom refuses altogether to admit mythological stories; but that these latter

\footnotetext{
${ }^{35}$ Here, as well as when he compares his vojage in the afterlife with that of Aeneas and Saint Paul (Inferno, II, 32), it is clear that Dante conceived of it as "real". The reality of Saint Paul's descensus is guaranteed by the Sacred Scriptures - an authority that such a deeply Christian mind as Dante's would never have
} 
were reinterpreted as the involucra of a superior truth and thus reduced to a unique History.

History is unique because it is the History of salvation. And the Church, as the material incarnation of this History of salvation, was the authority that claimed to be destined by God to interpret its truth. On this basis, the Church claimed its right to determine the criteria for the figural interpretation. The struggle for authority thus becomes the struggle for the right to interpret.

Luther's principle of an individual reading of the Sacred Scriptures (sola Scriptura) was the most tangible sign of a rejection of the authority of the Catholic Church. Luther strongly opposed allegorism in biblical exegesis. The Lutheran hermeneutical principle of sola Scriptura was fundamentally contrary to an allegorical and figural reading because the privileging of literal over allegorical meaning was also an opposition to the authority of the Catholic Church in fixing the codes of the interpretation.

But once the principle of the free interpretation starts to be admitted with the Reformation, a new process begins at the end of which the sacred logos cannot but find itself again as a plurality. Here the dialectic nexus of myth and the sacred logos fully emerges: the logos, the Word that presented itself as the uniqueness of a tautological truth ("I am he who I am") and constitutes itself as Holy History precisely by condemning the polytheism of myth, must find itself again as a plurality once more. It is at this point that Holy History, which was presented itself as a History in the singular precisely because it was unique in contrast to the plurality of myth, is shown to be nothing more than one of the many possible stories.

The first reaction to the rediscovery of the plurality of Histories is that of trying to recompose the unity on a different level. Protestant liberal theology, a result of the application of the philological method to the Sacred Scriptures and ending up as a claim for its "de-mythologisation" (Entmythologisienung) is clearly an attempt to recompose the dialectics of theological truth. In his programmatic conference of the 1941 Neues Testament und Mythologie, Bultmann denounced the mythical in the Sacred Scriptures: it is to this mythical element that, in his view, all the inconsistencies of the text are due. On the other hand, he contends, we can no longer believe in the

questioned, whereas for the reality Aeneas' travel the authority is Virgil, an authority that Dante fully accepts: (Inferno II, 13-15). 
stories of the Gospels: stories about the Resurrection and Assumption can no longer appeal to modern ears and must be considered nothing more than mere "myths". Hence the proposal for a new hermeneutical tool for the interpretation of the Sacred Scriptures: "demythologisation" (Entmythologisierung) - defined as the hermeneutical tool for assessing content of reality (Wirklichkeitsgehalt) of mythological texts (Bultmann 1962: 19).

The debate over demythologisation thus moves from the recognition within Christendom of the plurality that is defining of myth. All the same - so Bultmann continues - this plurality is simply a contingent plurality, i.e. it is the plurality of antiquated representations added to by the primitive catechesis and predications; as such, it must be kept separated from the kerygma, the unique, always living Christian message. Thus, whereas the stories in the New Testament are recognised as plural but then said to be antiquated, the kerygma, is said to be the always living and real unique message of salvation (Bultmann 1962: 33). In this way, the Entmythologisierung, whereas the on the one hand recognises the plurality of stories, it aims on the other at neutralising it by recomposing a new unity at the level of the kerygma.

Bultmann's proposal for an Entmythologisierung raised a huge debate. Among the scholars involved in this discussion, particular attention should be paid to the contribution of Jaspers (Bultmann and Jaspers 1954). Jaspers points out that for Christians the Entmythologisierung is a road full of traps since it can lead to the denial of the sacred character of the Scriptures. "Entmythologisierung - so writes Jaspers to Bultmann - ist fast blasphemisches Wort" ((Bultmann and Jaspers 1954:19). His response to Bultmann's proposal is not only an attempt to rehabilitate the mythical that was present in the Biblos: ${ }^{56}$ it was the recognition that once the mythical nature of the Sacred logos had been recognised, its range cannot be limited.

As a result, demythologisation is blaspheme because it amounts to denounce the dialectic of the sacred logos itself and thus to its own self-destruction. Indeed, once the mythical nature of God's Word has been recognised, it clearely becomes arbitrary to determine what the borderline is between the "mythical side" and the "kerygmatic core" of the sacred logos. And this arbitrariness cannot but reveal the tautological emptiness of the sacred itself. Thus, Jaspers' reply is not so much an attempt to

${ }^{56}$ This is, for instance, the interpretation by Jamme, who saw in Jaspers' reply a simple attempt to rehabilitate myth (Jamme 1991,107 ). 
rehabilitate the mythical as much as an attempt to save the sacredness of the logos, i.e. to recompose that opposition between "sacred logos" versus "myth" upon which the Exodus Commandment ultimately rests.

Ecumenical movements can be interpreted as the last of the attempts to recompose the uniqueness of the sacred logos at another level. When commenting on the concept of demythologisation, the theologian of inter-religious dialogue Raimondo Panikkar, observes that it is in the inevitable encounter of Christendom with other religions that the problem of demythologisation is exacerbated: the attempt to demythologise becomes inevitable precisely because of the inevitable confrontation of Christendom with other world religions (Panikkar 1962: 243). On the other hand, Panikkar observes, what renders the dialogue of Christendom with other religions impossible is precisely the pretension to exclusivity typical of Christendom: a Hindu might well recognise one avatara in the Christ, i.e. one of the possible manifestations of God in space and time, and even recognise His absoluteness, inasfar as any religion aims to be absolute, but he could never come to terms with its assumption of uniqueness and exclusivity (Panikkar 1962: 262).

According to the theology of the Anglican John Hick, the Euangelion of the salvation in Christ must therefore be recognised as a myth in itself, i.e. "the myth of the incarnate God" (Hick 1977). The Holy History of the Christ is now said to be nothing but a myth, simply one among many possible stories. However, even now that Christendom is recognised as a myth next to many others, a new reductio ad unum is predicated on a different level. In Hick's view, the recognition that Christ represents only one single "myth" i.e. one of the stories through which God has revealed Himself, should lead from a model constructed over the Christ of Christians to a model depending only on God: the different names of God are thus said to be only different historical incarnations of the unique divine truth, i.e. historical incarnations of the unique sacred logos. Once again, then, it is through the logos that a pretension to uniqueness is advanced, because it is the logos itself that is said to be the soteriological promise that is common to all religions (Hick 1982; Panikkar 1964). 


\section{SCIENTIFIC RATIONALITY AND THE DIALECTIC OF THE ENLIGHTENMENT}

Pierre Bayle, the author of the monumental Dictionaire historique et critique, the "real arsenal of all the Enlightenment philosophers", "the Bible of the eighteenth century" (Cassirer 1951: 167), imposes himself as philosophe with an earlier book, Various Thoughts on the Occasion of a Comet (1682). The occasion for this book was provided by the appearance of a comet, an event that caused a huge debate at the time. According to a widespread belief, comets were considered as a divine presage of great misfortunes and this clearely gave priests and theologians on all sides the opportunity for a lively discussion.

Various Thoughts was first published anonymously: the author presented indeed the book as a series of letters written by an anonymous writer to a theologian of the Sorbonne (Bayle 1682, 4). Camouflaging himself in this way, Bayle was thus able to express his criticism of the belief in comets as presage. Moreover he presented his criticism in the language of a theologian so that, as we read in the Preface, he could claim that the merit of these spontaneous letters written to a friend was that its "unknown author is willing to use, against the presage of comets, the same weapons belonging to piety and religion that have been used until now in favour of these presages" (Bayle 1682, 5).

Through this cover Bayle was thus able to put his intentions into practice optimally and even to put forward the most revolutionary statements, such as his famous argument in favour of a society of atheists. ${ }^{57}$ In particular, he could develop his argument against theologians in favour of an explanation of comets in terms of their physical causes. This latter only, in his view, could have deprived comets of their status 
of presages, a belief that he held responsible, among both the learned and the ignorant, of the worst sorts of foul prejudices and superstitions.

Through the typical escamotage of commenting an event of the past, Bayle was also able to explain the reasons why he has to make recourse to all these "precautions". By quoting Plutarch, he writes that in Nicias' time one did not dare to explain lunar eclipses in terms of natural causes except with one's own best friend and taking all sorts of precautions (Bayle 1682,110 ). This is so because when events are reduced to their natural causes, they presage nothing anymore and this, in its turn, deprives people of an infinite number of "vain imaginings" on which they feast and, as a consequence, it also deprives diviners of their employment (Bayle 1682, 110).

On the other hand, the political implications of these religious beliefs are clear. Indeed, a political critique seems to be the very rationale of Bayle's critique of the belief in comets as presages and of his appeal, against them, to the "enlightenment of philosophy". Again, in a humble passage, Bayle observes that in all times politicians have had a major interest in fomenting these beliefs, because nothing is as powerful in order to keep populaces in check. As Bayle explicitly says "however unruly and inconstant [populaces] may be, if their minds are once stuck by a vain image of religion, they will obey the diviners better than their chiefs" (Bayle 1982, 81).

Thus, in order to criticise this use of religious beliefs and to give support to his explanation of comets in terms of physical causes, Bayle found himself putting forward a critique of the reliance on "vain images and tales" in general. In this, it is not only the authority of theologians that he criticises, but also that of poets. In addressing the issue with his interlocutor, the presumed anonymous writer of the letter made explicit the approach that he expects from him: we should "nourish our mind only with an altogether pure reason" since "it is not possible to have a more miserable foundation that the authority of the poets" (Bayle 1682, 3).

In the name of "the enlightenment of philosophy" (les lumières de la philosophie) a criticism of all the "traditional tales" is put forward. "Pure reason" tells us that comets are natural events and are therefore explainable in terms of their purely natural causes; once this explanation has been put forward, there is nothing else in them that can link their occurrence with fortunes and misfortunes. Why, though should this view bring with it a condemnation of poets' tales?

${ }^{57}$ On this point see in particular chapter 7. 
We have seen that Plato condemned traditional stories because they were morally deceptive, the sacred logos condemned them because of their plurality; here, the condemnation is on a new ground: they are judged to be deceptive because they are "vain" and "imaginary" and thus "unreal", or, in other words, because they are mere myths (Bayle 1682, 3). What kind of "reality" is Bayle talking about? As we have seen, the Greeks did not even have a word for our "reality" and Scholasticism conceived of realitas primarily in reference to the res in it widest meaning and designating thus mostly the essentia of each res, so that realitas was used as a synonym of perfection. ${ }^{58}$ Clearly, it is to another view of the "real" that Bayle is referring. The "Real" is not here opposed to what is "imperfect", but rather fundamentally opposed to what is merely imaginary or ideal (Hoffmann et al, 1992).

Descartes was a turning point for the emergence of the "real" versus "ideal" dichotomy. He was the first to inaugurate the modern use of the term "idea" in the sense of a "mental content", whereas, as we have seen, the Ancient Greeks conceived of ideas as a being, or - even better - as the being that really is. ${ }^{59}$ Indeed, Descartes was one of the founding fathers of the scientific revolution and was thus one of the first philosophers to set up the typically modern problem of the separation between the knowing subject from the object of knowledge. It was because of this separation that the problem of the existence of an external world was first formulated. Notwithstanding the fact that Descartes used the word realitas in the old sense of perfection, ${ }^{60}$ he formulated the set of problems that went on to give rise to the contraposition between "real" versus "ideal" as it will be fully developed by Kant (Hoffmann et al. 1992)

Let us dwell briefly on the lines of reasoning presented in his Discours de la Méthode and his Meditationes de philosophia prima - they delineate an approach that was to become the model for successive enquiries into the possibility of knowledge. The staring point is one of methodical doubt: in order to test the certainty of knowledge, Descartes starts by casting doubts over whatever is liable to doubting. Thus he finds that all the truths he had received from his personal experience and education -

\footnotetext{
${ }^{58}$ As we have seen, this conception reached modern philosophers such as Spinoza (Et. II, def. 6) and Descartes (Med. 3, ax. 3).

59 See chapter 1. For an analysis of the history of the term ide, see "idea" in Abbagnano 1971, 450 and "Idee" in Neumann 1972

${ }_{60}$ As we have seen, in the Meditationes de prima philosophia one can still find expressions such as " realitas sive perfectio in aliqua re" (Med. 3, ax. 3)
} 
ranging from Scholastic metaphysics to sensitive certainty, and to mathematical knowledge - can be doubted.

Even in the case of mathematical thinking (the kind of knowledge entailing, in his view, the highest level of certainty) Descartes admitts the possibility of mistakes: this happens through the hypothesis of a malicious demon, which makes him believe, for instance, that "two plus two equals four". We get thus to the hyperbolic doubt where there seems to be no more truth, but only doubts. The way out of this is to claim that this is the truth itself: the only truth which cannot be questioned is precisely the fact that when one is in the process of doubting, and even if one is deceived, at that moment one will nonetheless be thinking and one can thus draw from it the certainty that one exists - at least as a res cogitans. This is the meaning of the Cartesian cogito ergo sum: the first certainty that human beings can reach is the fact of their existence as a res cogitans, i.e. the certainty of their existence as a knowing subject. ${ }^{61}$

The problem, to which Descartes devoted his thinking until his death, thus became that of the relationship between the res cogitans and the res extensa, i.e. how to move from the certainty of the knowing subject to that of the existence and knowableness of the external world. The solution proposed by modern science was to consider the extemal world as intelligible by the knowing subject only because of its being formed by matter and movement and therefore as expressible in mathematical language. Thus the multi-layered and complex world of the sacred logos was transformed into the simple world, made of matter and movement, of modern mechanicism. Only in virtue of this simplicity was the world readable by the knowing subject.

Descartes also gave a specifically philosophical formulation to a set of problems that Galilei had already partly and was partly formulating, whilst experimenting with his telescope and rolling balls. In Galilei's terms, the universe is also a book, but it is now readable because it is written in a mathematical language. This latter is what sets the scientific logos definitively apart from the "mythical"and the "imaginary". In his Il saggiatore - a book that, whilst discussing the nature of comets, delineates this new scientific method, Galilei strongly defends the "new philosophy",

${ }^{61}$ See the second Meditation, where Descartes concludes: "If I convinced myself of something or thought anything at all then I certainly existed. But there is a deceiver of supreme power and cunning who is deliberately and constantly deceiving me. In that case I too undoubtedly exist, if he is deceiving me; and let 
i.e. "science", specifically by juxtaposing it to what is described as a mere "fantasia d'uomo" (Galilei 1623, VI, 36).

Our philosophy, Galiei argues in this book, is not "una fantasia d'uomo come Illiade e l'Orlando Furioso" precisely because "philosophy is written in this vast book that is continually open before our eyes, i.e. in the universe; but this book cannot be understood without learning the language and the characters in which it is written. The book of the universe is written in a mathematical language, and its characters are triangles, circles and other geomethrical figures, without which it is impossible for humans to understand a single word; without these, it would be like wandering around a dark labyrinth in vain ( $e$ ' un aggirarsi vanamente per un oscuro laberinto)" (Galilei 1623, 6; trans. mine).

The universe is in front of us, we simply have to read it, but it is possible to read the universe only by learning to understand its mathematical language: without learning this language, " $e$ ' un aggirarsi vanamente" and it is impossible to understand anything about it. Experience, the same experience to which Bayle would refer as the only authority recognised by the "enlightenment of philosophy" (Bayle 1682, 4), is thus the trait d'union between the knowing enlightened subject and the object of the universe.

However, as the Galileian expression "sensata esperienza e certe dimostrazioni", i.e. sensible experience and certain demonstrations, suggests, it was not that all sensitive experience played such a role (Galiei 1613). If the world is written in purely quantitative terms, we have, in order to read it, to dismiss everything that has to do with qualities, i.e. all that becomes "merely subjective." Galilei is also the first thinker to formulate the distinction between what would be called "primary and secondary properties": whereas figures, weight, and movement are necessarily attached to any object of our experience and cannot be separated from it, other qualities such as colour, taste, etc are not necessarily attached to it and are therefore simply secondary. As he puts it:

"For this reason I started thinking that, in virtue of the part of the subject in which they lie, all these tastes, odors, colours, etc. are nothing but pure names that reside in the sensitive body, so that, once the animal is taken away, they also are annihilated" (Galilei 1623, 48; trans. mine)

him deceive me as much as he can, he will never bring about it about that I am nothing so long as I think that I am something" (Descartes 1641, Medit., II, 25). 
In these words, a boundary is drawn between what can be subject to scientific enquiry and what cannot inasfar as it resides in the "animal part" of the subject. Seventy year later John Locke, would write in his Essay conceming Human Understanding that only primary qualities are the "real properties" because they only "really exist" in bodies (Locke 1688, II, VIII, 9ff). On the contrary, colours, smells, tastes, sounds, and the other qualities perceived through the senses, "whatever reality by mistake we attribute to them, are in truth nothing in the object themselves": they derive from "a power of the subject to produce various sensations in us, whose real existence, though, depends on those other qualities such as bulk, figures, texture and motion that are primary because they are the real ones" (Locke 1688, II, VIII, 14).

Learning to read the book of universe therefore required a process of learning how to discern between "primary" and secondary "properties". These latter are, properly speaking, "not real" and one must therefore prescind from them in a scientific enquiry. In Galilei's words, we must get rid of the "animale", so that once "taken away ears, tongues, nases, there would remain only figures, numbers and movements" (Galilei 1623, 48; trans.mine). All that is not reducible to figures, numbers and movement is the merely subjective, i.e. in Locke's terms the unreal, and we must rid ourselves of it.

Myths - which are not reducible to a mathematical language - were thus said to be "unreal". As Horkheimer and Adorno pointed out, even if he had not yet understood the crucial role of mathematics, Francis Bacon's philosophy best represents the attitude of science towards myth (Adorno \& Horkheimer 1944). In Bacon's view, the construction of a true science should be preceded by a critique of all the false conceptions, or idola, in which human beings are immerged because of their subjective experience - be it the experience they derive from their nature or from their culture and education (Bacon 1627). The subject conducting the scientific enquiry has to deprive himself of every residue of myth since nature can only be mastered by "pure reason".

Bacon distinguishes four types of idola that must be removed in order to construct a Novum Organon: 1) the idola tribus, deriving from the innate characteristics of the human mind, such as its tendency to look for uniformities and that to make anticipations; 2) the idola specus, or the prejudices that human beings derive from their own "cave", i.e. according to the homonymous Plato's myth, from the fact that human beings usually live in the darkness and can only contemplate the shadow of 
things; 3 ) the idola fori, or the mistakes that derive from the use of language in social life, 4) and, finally, the idola theatri, i.e. the mistakes derived from a belief in the authority of traditions and ancient theories.

All the four types of idola are thus identified by Bacon as sources of prejudice, ambiguity and incomprehension: therefore, notwithstanding the fact that they are rooted in the very nature of the human mind, language and social life, the pure subject of scientific enquiry must rid itself of them. The idola theatri are, in a sense, the most significant because they reveal what is at stake in this process of removal. Why, one could ask, should human beings engage in such a costly enterprise and not remain in their idola if these are rooted in the nature of human mind and social life? The answer leads us to the core of the project of the Enlightenment: human beings had to rid themselves of the idola because otherwise they would remain prey to the authority and influence of others; in this sense, the struggle for liberation from the idola coincide with the struggle for individual autonomy.

It is no coincidence then that the modern scientific revolution took place through a discussion about the nature of comets and other astronomic phenomena. That is to say, the new scientific method was developed in order to uphold an astronomic revolution, and cannot be separated from it: the battle for modern science was a battle for a new conception of the cosmos and therefore also for the place that human beings occupy within it. ${ }^{62}$ When Galilei, using his self-made telescope, observed that, according to the "certezza che è data dagli occhi", the lunar landscape is similar to ours and that, again according to the authority of direct observation, there was no single centre of the universe (Galilei 1610), he was undermining the traditional view of the universe and of the human position within it.

This "traditional" image of the universe against which the "new philosophy" was constructed, was built around two pillars: the division between the lunar and sublunar worlds, and the idea of a closed universe in which the earth was at its centre. In 1600, Giordano Bruno was burnt as a heretic in Campo dei Fiori for having questioned these two pillars by sustaining the infinity of the universe. Subsequently, in 1616, Galilei was first ordered to abandon his Copernican view and then condemned for holding it in 1633 .

${ }^{62}$ Many authors have underlined this point: see in particular Blumenberg 1966. It is no coincidence then that, both Galilei and Bayle put forward their theories whilst discussing the nature of the comets (Galilei 1623 , Bayle 1682). 
The reason for those condemns is not only that all the teachings of the Church were enmeshed in the geocentric view supported by certain canonical passages from the Bible, but that they entailed a revolutionary change in the conception of the world and of the place of human beings within it. As a result of this revolution, operated on the basis of the "certainty given by eyes", the closed universe of the Aristotelic tradition divided into two spheres - perfection on the one side and imperfection on the other - became an infinite homogeneous universe made of matter and movement, where human beings were no longer relegated to imperfection. Whereas in the old multi-layered world human beings were finalistically assigned by God to the sublunar world, with the new image they found themselves projected into an infinite and homogeneous universe where no distinction in terms of greater or lesser degrees of perfection could be made. ${ }^{63}$

The battle for the new science was thus also a human battle for selflegitimacy against theological absolutism (Blumenberg 1966). Among the chief means by which this absolutism ruled was the "traditional" image of the universe as a closed and teleologically assigned multi-layered scheme. The process of self-legitimating went therefore through the destruction of this image of the world and the criticism of the authorities that supported it. The battle of the scientific logos for its self-legitimacy thus coincided with the project for human autonomy.

Kant defined Enlightenment (Aufklänung) as the exit from a condition of selfincurred immaturity: immaturity is the inability to use one's own understanding without the guidance of another and it is self-incurred because it derives not from a lack of understanding, but rather from a lack of resolution and courage to use it. The motto of the Aufklärung, according to the Kantian formulation, is therefore "sapere aude", to have the courage to use one's own reason, i.e. to be autonomous (Kant 1784).

However the Enlightenment's identification of autonomy with pure reason also threaten to become a mythology in its turn. As Horkheimer and Adorno pointed out in their Dialektik der Aufklärung, reason is not separated from myth, as the Enlightenment expects, so that the Enlightenment's celebration of the pureness of reason risks remaining entrapped in a dialectic movement at the end of which the pureness of reason can turn into a mythology of its own (Adomo \& Horkheimer 1944).

\footnotetext{
${ }^{63}$ On this point see for instance the classical work From a closed World to the Infinite Universe by A Koyré (Koyré 1957).
} 
In its search for self-legitimacy, the Enlightenment (Aufklärung) tends to exacerbate its contrast with myth and thus hides the fact that myth is already Enlightenment (Aufklärung); in this way, though, the Enlightenment (Aufklärung) itself risks to fall into a mythology, i.e. the mythology of an absolutise pure reason.

By criticising myth as being subjective and thus "unreal", the Enlightenment strengthens itself, for it asserts thereby the possible and necessary separation of the knowing subject from reality - a separation that, as we have seen, is at the very basis of the existence of scientific rationality as such. In this way, Enlightenment hides the fact that the myth is already Enlightenment because myth is already a form of explanation (Erklärung). But, on the other hand, the pureness of reason that Enlightenment celebrates can become a myth in its turn: once a pure reason has unified the whole world within its pure relationships and thus completely dominates it, what it finds outside there is no longer the world, but its totalitarian abstract categories (Adomo \& Horkheimer 1944). This dialectic of Aufklärung is the trap into which any sort of absolutisation of pure reason always risks to falling. ${ }^{64}$

In fact, the role of myth is to explain (erklären) inasfar as it concerns telling, naming and discovering the origins of things. For instance, if, together with Aristotle, we understand "causes" in the sense of the Greek aitiai, then we should also conclude with him that myth is the knowledge of causes. Instead, the Enlightenment denied that myth is already a form of knowledge, deriving this from a strict adhesion to the conception of causes that was developed by modem science. According to this view, causes are not the production of something, but rather the objective connections between events. ${ }^{65}$ The difference between this view and, let us say, Aristotle's view is best captured by comparing the image of artistic creation through which Aristotle explains his view of the aitiai ${ }^{66}$ and the typically modem metaphor of the billiard balls.

Billiard balls are the image used by $\mathrm{D}$. Hume in his discussion of the problem of causality. Here, we no longer have the production of something, responsibility, as was the case for Aristotle, but rather two events where one is the cause of the other: ball A touching ball $\mathrm{B}$, and ball $\mathrm{B}$ moving from a status of quiet to movement. To say

\footnotetext{
64 When writing their Dialektik der Aufklärung, Horkheimer and Adomo were faced with the positivism of the first half of the twentieth century. The idea of "dialectic of enlightenment" refers, however, here more to a category of the spirit, to an ever-open trap in which the absolutisation of pure reason can fall, rather than to a historically given form of Enlightenment.

${ }^{65}$ On the distinction between the Greek conception of aitiai and the modern view of causes see Chapter 1 and in particular Abbagnano 1971: 118.
} 
that "the movement of $\mathrm{A}$ is the cause of the movement of $\mathrm{B}$ " is to affirm that there is an objective, necessary connection between the two. But what is the basis of this "objective" connection? Hume maintained that there was no other basis for such a connection than mere habit (Hume 1739, I). Kant agreed with him that connection is not objective, but subjective, but he, however, called this subjectivity "transcendental".

Facing the sceptical objection raised by Hume over the possibility of grounding the connection between two events on something more than mere habits, Kant's answer was to admit that we cannot reach things as they are in themselves (noumenon), but precisely because of this, i.e. precisely because every possible knowledge is a phenomenical one, it is the subject, the transcendental subject, which becomes the criterion of truth itself. It is a "subject", then, but in Kant's view it is a transcendental subject, because it is the bearer of the a priori categories of experience, i.e. the bearer of the categories (space, time, causality, etc.) without which experience itself cannot exist (Kant $1781^{1}$ ).

If the external world has to be presupposed as the matter of knowledge, but it is capable of being only a formless substratum of experience, then once reason has reached the whole world, what it finds outside there is nothing other than its own categories. As Horkheimer and Adomo point out, by following Kant's line of thought, one must conclude that philosophy knows nothing because it merely repeats what reason itself has placed in the object (Horkheimer and Adorno 1944, I). "Reality" is thus nothing but what reason, disguised as objective empeiria, puts in it. In his Transcendental Analitic of experience, in the section of the Kritik der Reinen Vermunft aimed at deducting of the a priori intellectual categories of experience, we read that "possible" is whatever agrees with the "formal conditions of experience", whereas "real" (wirklich) is that which is connected (zusammenhängt) with the "material conditions of experience" (Kant 1787², B 266).

Kant's treatment of imagination is perhaps the most conspicuous sign of the Enlightenment's embarrassment with regards to myth. From the point of view of a genealogy of myth, this is perhaps the best way to show how the "mythical" that is constituted via exclusion from "rationality" is in fact often intermingled with rationality itself. Whereas in the first edition of the Critique, Kant emphasised the central role played by imagination for the possibility of knowledge itself (Kant $1781^{1}$,

\footnotetext{
${ }^{66}$ On this point, see chapter 1.
} 
A101), in the second edition he retreats from this discovery and relegates imagination to a secondary role (Kant $\left.1787^{2}, \mathrm{~B} 181\right) .^{67}$

Thus, in the first edition of the Critique, when looking for the source of that "pure transcendental synthesis" understood as condition of possibility of all experience", he identifies it with imagination itself and thus come close to admitting a sort of primacy of imagination (Arnason 1994:160). As we read in a crucial passage of the 1781 edition:

"If we can demonstrate that even our purest a priori intuitions provide no cognition except insofar as they contain the sort of combination of the manifold that makes possible a thoroughgoing synthesis or reproduction, then this synthesis of the imagination would be grounded even prior to all experience on a priori principles, and one must assume a pure transcendental synthesis of this power which grounds even the possibility of all experience" (Kant 1781, A101).

Imagination, as the active capacity for synthesis of the manifold, is thus said to be the condition for bringing the manifold of intuitions into single images and therefore also the transcendental condition of all knowledge. As has been observed, imagination, inasfar as it is the faculty that loosens mankind's relation to and reliance on wholly empirical conditions, can be said to be the truly transcendental faculty and therefore also the paradoxically concealed, yet "real", condition of all knowledge (Rundell 1994). Reason without imagination is dead reason.

However, in the second edition of his Critique Kant retreats from this perspective and relegates imagination to a more subaltern and intermediary role between intellect and intuition. Section A95-A130 of the Critique is replaced by a new section (B129-B169). In this latter, Kant distinguishes between what he calls the figurative synthesis of imagination from its intellectual counterpart, the transcendental schematism, which remains still today one of the most obscure concepts in the Critique (Kant $1787^{2}$, B 152, B 181):

"This schematism of our understanding with regard to appearances and their mere form is a hidden art in the depths of the human soul, whose true operations we can divine from nature and lay unveiled before our eyes only with difficulty. We can only say this much: the image is a product of the empirical faculty of productive imagination, [...] the schema of a pure concept of the understanding, on the contrary, is something that can never

${ }^{67}$ Among those who have recently insisted on this point as a crucial step in order to rethink the faculty of imagination, see Arnason 1994, Castoriadis 1994; Rundell 1994. 
be brought to an image at all, but is rather pure synthesis" (Kant $1787^{2}, \mathrm{~B}$ 181).

Thus whereas the Kant of the first edition of the Critique seems to hold that imagination is the truly transcendental faculty of the synthesis and thus the very condition of the possibility of knowledge, a few years later he drew back from this discovery. By downsizing his previous claim over the formative power of the imagination and its crucial role in the process of knowledge, he restates a more conventional division between reason and imagination, science and art, and thus also, as we will see, between critique and creativity: in this way, critique collapses into cognitivism and the imagination is treated either mediately or aesthetically (Rundell 1994a).

"Imagination", which Bayle has condemned as "vain", was thus progressively associated with the ambit of aesthetics. Correspondingly, the Aristotelic term for imagination, "phantasia", was moved to the realm of the unreal (Friese 2001). Whereas Aristotle recognised a crucial role for the "phantasia" in the process of knowledge, both because it preserves that which has made an imprint on memory (reproductive phantasia) and for it belabours the phantasmata of knowledge (productive phantasia) (Friese 2001), ${ }^{68}$ Galilei, as we have seen, instead considered the "fantasia" as the ambit of poetic "fantasy" and thus as the opposite of scientific knowledge (Galilei 1623, 6). At the same time, "imagination", as the modern correspondent to Aristotle's "phantasia", was excluded from the ambit of knowledge and became the faculty of poetry par excellence (Vattimo 1999b).

This process corresponds to what Gadamer has called the subjectification of aesthetics (Gadamer 1960, I, II). "Art" as an autonomous domain grounded on the notion of taste is indeed a creature of modernity. Whereas up to modern times the term art (ars) covered a very wide meaning including everything that had to do with the application of general principles to a certain domain, so that in the middle ages artes included dialectic (i.e. philosophy itself) together with grammar, rhetoric, arithmetic, geometry, astronomy and music; in modern times, the meaning of the term was restricted to that of "beautiful arts". 69

\footnotetext{
${ }^{68}$ For an analysis of the view he put forward in the De Anima in comparison with the modern view, see Friese 2001, and Castoriadis 1994

${ }^{69}$ A trace of the medieval use of the term "art" can still be found in institutional labels such as "Faculty of Arts" or the titles "Bachelor of Arts" or "Master of Arts".
} 
Thus, whereas the category of beauty was initially dealt with in the treatises of metaphysics, now it became the object of a specific discipline whose autonomy is guaranteed by the concept of taste (Vattimo 1999a). Kant's third Critique (Kant 1790) is a turning point: in the preface of this book, Kant labels aesthetical the judgement concerning the beautiful and the sublime in nature and in art (Kant 1790, pref.). The judgement of taste is defined by a contraposition with cognitive judgment: whereas this latter operates by subsuming the particular in a general rule, the former is that kind of judgement where a universal is looked for in the particular. Therefore even if these judgements rest on a spontaneous aggrement with a subjective sentiment of pleasuredispleasure and at the same time they are expected to have some kind of universality because linked to a sort of "aesthetical common sense" (Kant 1790, 22), they do not contribute in any way to the advancement of knowledge. ${ }^{70}$

The process of the subjectification of aesthetics thus went hand in hand with its autonomisation. Morals went through an analogous process. In other words, if "possible" and "real" came to mean what respectively "agrees" and is "connected" with the conditions of experience, namely, the intuition of space and time and the categories of understanding, for a reason caught in the dialectic of Aufklärung the problem arises of what to do with evrything that does not fall within these conditions. Are we destined to "aggirarsi vanamente per un oscuro laberinto" as Galilei suggested?

The answer given by romanticism to the autonomisation of different spheres was to call for a "new mythology" (Frank 1982). In Das älteste Systemprogramm des deutschen Idealismus, a text attributed to the three disciples of the Tübinger Stift Hegel, Hölderlin and Schelling, the restoration of myth took the form of an appeal to a new mythology presented as the only way by which to overcome the mechanisation operated by the Enlightenment. The myth appears in this text as to encompass all that pure reason is not. However, as we will see, in this way the appeal for a "new mythology" ends up with reproducing the Enlightenment's view of myth by simply inverting its axiological connotation, rather than radically questioning it.

In particular, according to the authors of this document, the program of a new mythology should encompass ethics, politics, aesthetics, and religion. The document

\footnotetext{
${ }^{70}$ Thus, Kant set the judgement of taste a part from knowledge and at the same time, by referring to the notion of "common taste" i.e. a way of feeling shared by a human community ideal and effective he laid the ground for that connection between aesthetics and the philosophy of history that is characteristic of romanticism (Vattimo 1999a).
} 
starts with an invocation of an ethics understood in a Kantian fashion as a system of all the ideas or postulates of reason - first of all, the postulate of the Ich as the absolute free essence (Hegel, Hölderlin \& Schelling 1796: 234). With the idea of a free essence also emerges the idea of nature understood as world for a moral essence; from this we move to the realm of the Menschenwerk: here, the claim is advanced that all human products that are incompatible with the idea of human freedom should be overcome (aufgehoben); in particular, the political form of the state, which always implies something mechanical (etwas Mechanisches), since it treats human beings as Räderwerke rather than as free essences, should disappear (aufhören). The program of new mythology thus becomes also a political program for the demolition of the state: "Wir müssem also über den Staat hinaus!" (Hegel, Hölderlin \& Schelling 1796: 234).

From this radicalisation of the Kantian idea of freedom the document moves on to the idea of beauty, presented in the "platonical sense" (Hegel, Hölderlin \& Schelling 1796: 235). Beauty is seen as the culminating point of the program since it unifies all other ideas (freedom, truth and goodness) within itself. As a consequence, the young authors of the text can conclude: "Die philosophie des Geistes ist eine ästhetische Philosophie" (Hegel, Hölderlin \& Schelling 1796:235). The philosopher is therefore required to exhibit the aesthetic sense (äesthetische Sinne) of a poet: those who do not posses it are "Buchstabenphilosophen". The Buchstabenphilosophen, the ultimate products of the Enlightenment, are those who can work only with numbers and the abstract categories of intellect and are thus completely lost "when it comes to going beyond Tabellen und Register": beyond tables and numbers the Buchstabenphilosophen must necessarily confess that they know nothing (Hegel, Hölderlin \& Schelling 1796:235).

In the text, thus, a dichotomy is drawn between the Buchstabenphilosophie, product of the Enlightenment with its mechanicistic view of the world, and - on the other hand - a "Philosophie des Geistes" which unifies within itself all that is seen as left out by the former: the idea of human beings as free essence, grounding the possibility of a moral and also political realm of absolute freedom; the aesthetical sense, with its unification of truth, freedom and goodness; and, finally, also a new form of religion. Paradoxically the program for a new mythology, which moves from a radicalisation of the Kantian idea autonomy up to the extreme result of an anarchic program, ends with an appeal for a religion: 
"The great masses, so they wrote, need a material religion of the senses [eine sinnliche Religion]. Not only do the great masses, but also the philosopher needs it. Monotheism of reason and heart, polytheism of the imagination and art, this is what we need [...]. We must have a new mythology, but this mythology must be at the service of ideas. It must be a mythology of reason [...]. Then perpetual unity will triumph among us" (Hegel, Hölderlin \& Schelling 1796, 235; transl. mine).

Thus, whereas in the mind of the young architects of the program the claim for autonomy should have led to a reign of absolute freedom where even the state, seen as "etwas Mechanisches", should have disappeared in the name of individual freedom, already in this text, but in particular in its successive historical manifestations, the appeal for a new mythology tends to be resolved into the sole appeal for myth understood as the totality. In this way, myth and religion, which were assimilated by the Enlightenment's critique of all the "vain imaginings" (Bayle) or "fantasie d'uomo" (Galilei), are unified once more, so that the appeal for a "new mythology" tends to simply reproduce the Enlightenment's view of myth. Perhaps the more conspicuous sign of this tendency is that the appeal to myth tends to resolve into religion and therefore into the heteronomy of a divine revelation.

Schelling's intellectual trajectory is paradigmatic from this point of view. Schelling, who is considered the major contributor to the text, ${ }^{71}$ identified mythology as the place of the divine revelation of God a person in the later developments of his philosophy (Schelling 1856-1861, XXIV). Myth becomes here the ambit of the immediate intuition, where the God of monotheism reveals himself. In this way the new philosophy of mythology resolves itself into an attempt to simply "restore" myth, i.e. into an appeal for myth as it had been conceived by the Enlightenment itself. As has been observed, Schelling's philosophy of mythology does not deal with the new, but rather with the oldest of the mythologies (Marquard 1979:50).

Indeed by subordinating the content of truth of myth to revelation, Schelling's philosophy of mythology more than a theory of myth is a theory of the end of myth, which is overcome by revelation (Lotito 2002: XL). Schelling subordinates myth to the logos (Volkmann-Schluck 1969:111ff). In other words once that the logos, now understood as reason and now as sacred logos, i.e. as word of a God revealing himself,

\footnotetext{
"On this point see Frank 1982, 6.
} 
is identified as the telos of myth, there is only space for "a final great myth". In this sense, as Blumenberg has pointed out, Schelling's philosophy of mythology is an attempt to bring myth to an end (Blumenberg 1979, VIII).

Blumenberg extends his interpretation of Schelling's philosophy as attempt to "bring myth to an end" to the whole German idealism. On the other hand, Blumenberg suggests rather than fully develops his interpretation. Nevertheless, his few remarks on the topic, seems to be sufficient for suggesting a new possible interpretive perspective on German idealism. Indeed, it seems as if to read for instance Hegel's philosophy as a reply to the program of a "new mythology" could be a very productive heuristic strategy. ${ }^{72}$ For instance, whatever the role of Hegel was in the writing of Das alteste Systemprogramm, the idea of a philosophy of spirit as an "aesthetical philosophy", i.e. as a combination of the "monotheism of reason" with "polytheism of imagination", may perhaps throw some light over the interpretation of the Phenomenologie des Geistes (Hegel 1807).

All the same, it seems as if it is the aspect of "monotheism of reason" that prevails in the later developments in Hegel's thinking. Myth becomes here an earlier stage in the unfolding of the spirit understood as freedom, precisely the stage where it does not yet know itself as free, and needs therefore the pollution of sensitive images (Verunreinigung des Gedankens durch sinnliche Gestalt) (Hegel 1832-45, XIX, 1,3, A). At the same time, the Kantian idea of autonomy, which should have led to the Aufhebung of the state in virtue of the realisation of a pure realm of freedom in the program for a new mythology, is here replaced by the adhesion to a real (wirklich) that is said to be rational (vernünftig) in itself (Hegel 1821, Vorrede).

On the other hand, the idealist philosopher that most influenced romantic theories of myth was not Hegel, but Schelling (Jamme 1991:35). The first Hölderlin for instance also aims at recovering the ancient world of Greek mythology as a tool for the critique: in the first lyrics such as the Hymne an den Genius Griechenlands or in the Hymne an die Göttin der Harmonie, he presents the mythological figures of ancient Greece as symbols of a natural harmony that is seen as lost under modem conditions (Hölderlin 1981). The Greek mythology is thus recovered as symbols of harmony ruling a nature pantheistically conceived. Myth becomes the medium of an aesthethical

\footnotetext{
${ }^{72}$ This is a point that would deserve to be pursued. To my knowledge. Blumenberg's suggestion has not yet been taken up systematically. Apart from Blumenberg's remarks (Blumenberg 1979:VIII) helpful insights towards this direction can be found in Frank 1982.
} 
experience in which the union of the subject and the object is realised once more (Hyperion). ${ }^{73}$

Through a trajectory similar to that of Schelling, in his later production, Hölderlin's conception increasingly assumes the connotation of a religious experience: myth becomes the dress of God ("Gott an hat ein Gewand"), the medium of a superior religious experience in which the Luteran Deus Nudus reveals himself as Deus Vestitus (Griechenland, Zweiter Entwurf). The God that appears in the later lyrics is indeed the God of monotheism: the recurring figure of Christ, which is syncretistically accompanied by Heracles and Dionysius, is now celebrated as the only universal God (Patmos; Der Einzige).

However, once more this view of myth as a totality assimilating myth and religion does not question, but simply invert the axiological connotation of the Enlightenment's view. When myth is considered as the ambit of the immediate intuition, through which only the true revelation, i.e. the manifestation of God as a person, can take place (Schelling), or as the dress of God, the medium of a superior aesthetical experience which embodies the ethical experience of a people (Hölderlin), the presuppositions of the Enlightenment are not rejected but instead reinforced. The fact that the intellectual trajectories of these authors end up in the celebration of myth understood as the medium of a divine revelation and thus as heteronomy is thus perhaps the more conspicuous sign that romanticism has accepted the dichotomy of scientific reason versus myth created by Enlightenment.

On the contrary, it is by radically questioning these presuppositions that we must start. In the first place, thus, by rediscussing the identification of the project of autonomy with the project of a "pure reason". Not all that is not "pure reason" is heteronomy: myth, in particular, does not always coincide with religious revelation in general and even less with the revelation of God as a person of Christendom in particular. Rather, as the dialectic of the sacred logos shows, the plurality of myth can be fundamentally hostile to theological absolutism.

On the other hand, following a crucial insight of early romanticism we must recognise that myth is itself a possible means for the project of autonomy. Only by identifying - together with Kant - "autonomy" with the "pureness of reason" can one

${ }^{73}$ On Hölderlin's recovery of myth as the medium of a superior aesthetical experience realising the union of the subject and object, see Hübner 1985. 
possibly deny this fundamental fact. However, if one literally understands by autonomy the possibility of giving oneself one's law, one must also recognise that autonomy means interrogation of the existing. As a consequence, imagination can also be one of the means for questioning what is given and thus of critique. ${ }^{74}$ In other words, we should recognise that imagination is as central as reason to modernity (Amason 1994).

Together with the repetitive imagination, one should also recognise the existence of what Castoriadis has called the radical imagination (Castoriadis 1975). Imagination is radical because, as Kant discovered in the first edition of the Critique, it is at the basis of the possibility of knowledge itself, but also because it creates $e x$ nihilo - which means not in nihilo or cum nihilo. Imagination operates with preexisting material, but it can also always create ex nihilo because it can potentially always question its own products (Castoriadis 1994).

Whereas a great deal of philosophical work has been done on the concept of reason and its possible contribution to the project of autonomy, nothing similar has been done on the concept of imagination. In comparison to reason, imagination has thus remained a marginal topic in recent philosophical debates. In particular, just as the move from a philosophy of subject to a new emphasis on context has led from a theory of "reason" to one of "rationality", we need a parallel development from a theory of "imagination" to a theory of the "imaginary" (Arnason 1994). Certainly some steps have been taken in this direction - Castoriadis' work on the "imaginary institution of society" being the major recent example (Castoriadis 1975); but the disparity with the amount of work done on the concept of rationality remains overwhelming.

In addition, we now seem to dispose of the theoretical means for going beyond the very alternative between Enlightened versus Romantic views of myth. In particular, starting with the second Wittgenstein's philosophy, alternative views of meaning and language have been developed. Now that the linguistic turn has given rise to a new emphasis on the different routes for the construction of reality and that the virtual, the imaginary par excellence, has in a sense become the most real, there is a chance for further steps ahead.

\footnotetext{
${ }^{74}$ On myth, the project of autonomy and the possibility of critique, see in particular chapter 7.
} 
The genealogy of myth must not be understood as an invitation to return to the "origins of myth". It would be wrong to conclude from a genealogy of myth that "myth" is simply "word" because in Homer mythos was "word". This reasoning rests on a sort of fallacy of the origins, namely on the idea that what came at the beginning was good just because it was at the beginning. Indeed, such an idea, if not further justified, can indeed easily tum into an empty tautology.

At the same time, even if the tautology is avoided, doubts may still arise over the feasibility of a hermeneutical jump back. The world we live in is much more complex than Homer's, so that to hope that, by simply going back to the Homeric "mythos", we could also go back to that simplicity. This, indeed, is the reason why Nietzsche's appeal for a return to myth could not but tum into a call for an impossible restoration. In particular, Nietzsche shares with Romanticism the idea of modernity as the epoch that has exterminated myth (Nietzsche 1872). As a result, his approach to myth also tends to reproduce the Enlightenment's view of myth, by simply inverting its axiological value.

On the contrary, the proposed genealogy of myth is not a call for a restoration of myth, but rather an attempt to recall the conceptual movement that gave birth to the view of myth as "untruth" and "unreal" from which it began. Once the forces at work in it are identified, there is hope that we can go beyond the view that they have shaped. In particular, once it is discovered that the "untruth" and "unreality" of myth are consequences of the dialectic, respectively, of the sacred and of the scientific logos, we can attempt, by leaving the assumptions that they have brought with them aside, to go beyond the view of myth as untrue and unreal from which we started. 
Contemporary thinking seems to provide the means for doing so. If the genealogy of myth shows that to stigmatise myth as untruth and unreal means to approach it from the point of view of a unique truth (sacred logos) and of an absolutisation of reason (Enlightenment), Chapter 4, follwing Wittgenstein's insights, is meant to point out that any approach to myth in terms of truth is essentially flawed. This is indeed a crucial step because, as we have seen, the most important contemporary theories of political myth, despite the fact that they do not stigmatise myth as necessarily false, still define it in terms of its claims to truth (Lincoin 1989, Flood 1996).

Moving from Wittgenstein's characterisation of human beings as "ceremonious animals", Chapters 5 and 6 delineate a possible approach to myth understood as one of the forms in which the ceremonious activity of human beings takes place. Whereas Wittgenstein scattered remarks on myth unify very different phenomena such as rituals, religious beliefs etc. under this heading, Blumenberg's reflection on myth provides crucial insights on the specificity of the working on myth. While discussing some of the most important theories of myth (in particular Cassirer and Vico), Chapter 5 focuses on some crucial features of the working on myth, whereas Chapter 6 discusses Blumenberg's view of myth as a narrative that responds to a need for significance. 


\section{MYTH AND MEANING}

In 1890 the first two volumes of a monumental anthropological work on magic and religion were published: they were Fraser's Golden Bough. In this work, later republished in twelve volumes (Fraser 1911-1915'), Fraser collected an enormous amount of material concerning traditional beliefs and social practices from different societies. By classifying the material according to the criteria of evolutionary comparativism, he attempted to develope an explanation of "magic behaviour". Magic, he argues, is based on the belief of a correspondence between entities that àre separated in space and time but are, nevertheless, linked to one another. This link, according to Fraser, can be thought about in two different ways: either as the relationship between part and whole, so that by acting on one part, an influence on the whole can be realised, or as an imitation, so that by fictitiously reproducing an object or an act, its effective realisation can be expected to come about (Fraser 1911-1915 $\left.{ }^{2}\right)^{75}$.

Thus, according to Frazer magic is based on the application of beliefs that are inaccurate in se, and are therefore pure myths, but that are nevertheless applied in a way that can be defined as rational and coherent. Whilst analysing the myths of "ruder ages and races, we shall do well to look with leniency upon their errors as inevitable slips made in the search for truth, and to give them the benefit of that indulgence which we ourselves may one day stand in need of" (Fraser 1911-1915 2 : 264). In other words, "their errors were not wilful extravagances or the ravings of insanity, but simply hypotheses, justifiable as such at the time when they were propounded, but which a fuller experience has proved to be inadequate. It is only by the successive testing of

\footnotetext{
${ }^{75}$ According to Kirk. Fraser's work on myth is the archetype of the comparative anthropological trend that dominated for the whole twentieth century (Kirk 1970,3).
} 
hypotheses and rejection of the false that truth is at last elicited. After all, what we call truth is only the hypothesis which is found to work best" (Fraser 1911-1915 ${ }^{2}$ ).

Myths, according to this view, are thus read as a sort of forerunner, however mistaken, of the inductive and deductive procedures of science. One of the strongest critics of this view was Ludwig Wittgenstein. In his Remarks on Frazer's Golden Bough, he points out that the major weakness of Frazer's account of the magical and religious notions expounded is that "it makes these notions appear as mistakes" (Wittgenstein 1967b, le). In other words, even if Frazer appears to be indulgent towards the notions and practices he analyses, he does by adopting a point of view that is fundamentally flawed: he looks at them as if they were supported by certain "hypotheses" about the constitution of the world and, thus, as if they could be found to be "true" or "false", "right" or "mistaken".

As we will see, these kinds of judgements are not only deem to fail to capture the nature of social beliefs and practices, since they interrogate them as if they were scientific hypotheses, but - moreover - they are based on a limited view of what language and meanings are about. Judging magical and religious notions as mistakes means bringing these notions onto a terrain that is not their own and interrogating them from the standpoint of an overtly limited view of language. Thus, after having pointed out to the deficiencies of Frazer's account, Wittgenstein asks provocatively:

\footnotetext{
"Was Augustine mistaken, then, when he called on God on every page of the Confessions?

Well - one might say- if he was not mistaken, then the Buddhist holy man, or some other whose religion expresses quite different notions, surely was. But none of them was making a mistake except where he was putting forward a theory" (Wittgenstein 1967b,1e).
}

Thus, according to Wittgenstein, one cannot come to terms with myth, magic and religious notions by interrogating them over their truth value. As the dialectic of myth and logos also shows, there must be an expectation of "truth"- understood as "unique" or as "objective" - in order to have a "mistake". In magic and religious notions, however, no mistakes can ever exists inasfar as they do not aim at advancing any theory. Indeed, as Wittgenstein points out, there is a whole set of meanings and actions that human beings carry out in their everyday life that clearly do not rest on any 
expectation of truth and that do not thus presuppose any theory. As he argues by using two persuasive examples:

"Buming in effigy. Kissing the picture of a loved one. This is obviously not based on a belief that it will have a definite effect on the object which the picture represents. It aims at some satisfaction and it achieves it. Or rather, it does not aim at anything; we act in this way and then feel satisfied" (Wittgenstein 1967b,4e)

There are actions thus that do not aim at something, but are rather fulfilled by simply performing them. The meaning of "kissing the picture of a loved one" must not be looked at as something different from the action of "kissing the picture of a loved one" itself. As an action, it expresses a desire and fulfils it at the same time; as a meaning, it is all present in itself. It is in this context that Wittgenstein puts forward his provocative thesis of "human beings as ceremonious animals"76 (Wittgenstein 1967b, 7e):

"We could almost say, man is a ceremonious animal. This is partly false and partly nonsensical but there is something in it.

In other words, one might begin a book on anthropology in this way: When we watch the life and behaviour of men all over the earth, we see that apart from what we might call animal activities, taking food \&c. \&c, men also carry out actions that bear a peculiar character and might be called ritualistic.

But then it is nonsense if we go on to say that the characteristic of these actions is that they spring from wrong ideas about the physics of things (this is what Frazer does when he says magic is really false physics, or as the case may be, false medicine, technology, \&c.)

What makes the character of ritual action is not any view or opinion, either right or wrong, although an opinion - a belief itself can be ritualistic, or belong to a rite (Wittgenstein $1967 b, 7 e)$.

Frazer's view of myth and rituals as "mistaken" derives from a misunderstanding about the nature of these notions and practices. Indeed, only by assuming that the aim of these notions is to describe facts - what can only be either "true" or "false" - can one consider these notions as "diseases of language". This latter

\footnotetext{
${ }^{76}$ On Wiigenstein's idea of human beings as ceremonious animals and its relationship with anthropology, see in particular Bouveresse 1982. On Wittgenstein and anthropology, see Bouveresse 1982, Das 1998, and Clack 1999.
} 
is the famous expression coined by Max Müller to underline the fact that the stories told by myths are intrinsically "untruthful" and "unreal". By starting from the assumption that the fundamental business of language is to describe facts, Müller was led to conclude that ancient myths derived from the misunderstanding of names, especially those attached to celestial objects (Kirk 1974:43).

Paradoxically, though, Frazer's view of myth is based on a conception of language to which Wittgenstein himself made a fundamental contribution. Simplifying things, one might state that this is the paradigm that has dominated in the philosophy of language over the last century (Marconi 1999: 15). Gottlob Frege first elaborated its fundamental theses. However they were precisely Russell's and the early Wittgenstein's writings - in particular the Tractatus Logico-philosophicus (1921) that filled out the fundamental countours of this paradigm.

The paradigm can be briefly summarised as the combination of three theses (Marconi 1999: $15 \mathrm{ff}$ ). The first asserts that the meaning of a proposition is given by its "truth conditions", i.e. by the specification of the circumstances in which a proposition is true. Thus, this theory of meaning is a theory of the propositions and assertive propositions are the privileged units of interest. Second, the meaning of a complex expression is considered to be functionally dependent on the meaning of its smallest basic parts, so that, for instance, the meaning of any single unity of a proposition is given by its contribution to the meaning of the proposition. This is the thesis known as "logical atomism" and points to the composite nature of meaning. The third thesis asserts that, given that the meaning of an expression is provided by the combination of the first two theses, any psychological consideration over the mental representations associated with the linguistic expressions is irrelevant for a theory of meaning.

Sentences are thus pictures of facts, the meanings of complex expressions are given by the combination of their constitutive parts and everything that cannot be reduced to this belongs to the category of the "mystical" and, properly speaking, is deprived of meaning (Wittgenstein 1921, 6.44). As Wittgenstein concludes his Tractatus, "The correct method in philosophy would really be the following: to say nothing except what can be said, i.e. propositions of natural sciences - i.e. something that has nothing to do with philosophy - and then when someone wanted to say 
something metaphysical, to demonstrate to him that he had failed to give a meaning to a certain sign in his propositions" (Wittgenstein 1921, 6.53).

Even from such a brief picture it should be clear that within such a view of language there cannot be much place for a philosophical treatment of myth. Scepticism would be twofold: towards myth as an object and towards philosophy as a suitable method of enquiry. In other words, if "the essential business of language is to assert or to deny facts" (Russell 1921:10), and assertive propositions are consequently the atoms of any meaningful expression, then either we can reduce myths to these assertive propositions or we have to conclude, with Max Müller, that myths are a "disease of language". This seems to be early Wittgenstein's position: only how things are in this world can be said, the rest being "mystical" (Wittgenstein 1921, 6.44). Or again, as he wrote at the end of his Tractatus: "We feel that even when all possible scientific questions have been answered, the problems of life remain completely untouched" (Wittgenstein 1921, 6.52).

Philosophy is not reserved any better place within this paradigm. No philosophical enquiry had ever limited itself to a collection of assertive propositions and no place seems therefore to be left for her in the field of meaningful enquires. On the other hand, this limitation to such a restricted ambit of language - assertive propositions - is selfdefeating in the long run, for not only is the assertion of the meaninglessness of philosophical enquiry self-contradictory, given that any such assertion is itself philosophical, but also entails too a limited view of language.

When Herbert Marcuse was imprecating against the reduction of philosophy to the analysis of sentences such as "the broom is in the comer", he was not only pointing to the dangers of political conformism that such one-dimensional thinking implies (Marcuse 1964, 7). He was also pointing to the fact that what is analysed is not the language that we actually use in our life, with all its complexities, but desegregates atoms of language. These latter - he observed - are, in the best-case, baby talk: sentences like "he saw a robin", "I had a hat" are far from being representative of our language (Marcuse 1964: 175). Yet, much of contemporary analytic philosophy is still devoted to this kind of analysis. Tarski's widely accepted theory of meaning is all enclosed in the profound and complex sentence: "the snow is white if - and only if - the snow is white". The problem here is not only that by taking fragments of common language as a guide to the research there is a great risk of remaining trapped in the 
positive acceptance and reification of single historical forms; it is also that these fragments represent such a limited part of our language that to take them as unique objects of enquiry cannot but be misleading for an understanding of what human language is about.

Wittgenstein's self-critique is perhaps the best way of distancing ourselves from these views. And notwithstanding all the claims about the continuity of his thinking, most of the philosophy he developed after the thirties appears as a sort of profound self-critique, so that, it has became common to talk of a "second Wittgenstein". The insights that can be drawn from his later writings opened up a completely different perspective on the nature of language and meaning - and this perspective, as we will see, is perhaps the perspective that can best support a philosophy of political myth.

Wittgenstein's Philosophical Investigations start with a critique of the view of meaning that we have been analysing above. He now puts this view under the name of Augustine and his major criticism is that such a "philosophical concept of meaning has its place in a primitive idea of the way language functions. But one can also say that it is the idea of a language more primitive than ours" (Wittgenstein 1953, 3; emphasis mine).

Wittgenstein now moves from the assumption that the essential business of language is not to describe facts, but that we instead do a number of things that are not - and cannot - be judged according to their truth or falsehood with language. When we give an order, provide a suggestion, make a joke, ask for something, thank someone for something, pray someone, tell a story or even construct a scientific hypothesis - just to give few examples - its is not by the criterion of their truth that we expect them to be judged. Wittgenstein's major point is now that, we play all sorts of language-games through language (Wittgenstein 1953). Meanings are not the picture of facts, but they are embodied in the language-games that we play continuously, where a languagegame is defined as an indissoluble whole made of language and the actions into which it is woven (Wittgenstein 1953,7).

The concept of "game" is meant here to stress that the rule embodied in wholes made of language and actions are constitutive of meaning. This does not mean that language is the domain of the arbitrariness of games - however. Indeed, rules govern our use of language, as is shown, for instance, by the fact that we do not learn a language sentence after sentence. Rather, we construct sentences by putting words 
together according to certain rules - no matter whether we have learnt these rules intentionally as when we learn a foreign language or we internalise them by imitation, as children do.

When Wittgenstein elaborated the concept of language-game, he probably had in mind precisely the constitutive role of the rules of games. When one does not follow a rule in the game of chess, one is not simply doing something wrong: one is playing another game. However, the idea of a game also points at the same time to the fact that it is our acting that lies at the bottom of the language (Wittgenstein 1969,501). When dealing with meaning, it is not only with an act of saying that we have to do, but also at the same time with an act of doing.

In other words, the grammar of a language, i.e. the eliciting the rules governing certain linguistic expressions, is not sufficient to reconstruct their meaning. Wittgenstein does not provide a definitive answer on this point, and, for instance, in the Philosophische Grammatik there is a passage where he seems to suggest the opposite, i.e. that: "der Ort eines Worts in der Grammatik ist seine Bedeutung" (Wittgenstein $1969,23)$. The problem seems to be to understand what Wittgenstein meant by "Grammatik" - a point on which he always remained ambiguous.

However, it seems that towards the end of his life he became increasingly sceptical about the possibility of even describing the rules of language-games. These latter are always changing and are much too varied to provide a definitive grammar of them. All these perplexities emerge particularly in the remarks published with the title On Certainty. As we read here: "Am I not getting closer and closer to saying that in the end logic cannot be described? You must look at the practice of language, then you will see it" (Wittgenstein 1969b, 501).

Whatever the right interpretation of Wittgenstein is, a couple of points can be drawn from this debate. One of these is that grammar - understood a compilation of rules - is a necessary but not yet sufficient condition for understanding the meaning of a sentence. In the first place, this is because sometimes a fully descriptive rule cannot be compiled. In these cases, there is simply not enough generality to extrapolate them from use. Whoever has some experience in learning a foreign language knows that there are sometimes no rules for the employment of certain expressions. They are simply used, and are used in a way that does not allow for generalisation and therefore for the eliciting of rules. 
Here it becomes clear that, as Wittgenstein persuasively sustained, the meaning of an expression derives from its use. And the term "use" must here be understood in its widest meaning - as encompassing both the possibility to extrapolate rules and the dimension of action (Wittgenstein 1953,43 ).$^{77}$ In other words, the meaning of an expression is not only given by the rule that emerges from our use of a certain expression in our action. It is also the continuosly-changing context against which this rule must be seen that contributes to the meaning of an expression. To put it in a slogan, we might say: "no meaning without use, and no use without a context". Indeed, it is also the context, i.e. the background against which we see each actions within each single language-game that is crucial to our understanding of the meaning of a word (Wittgenstein 1967a, 567).

Let me illustrate the point with an example. Take the sentence "Close the door". Clearly this expression can acquire very different meaning according to the different contexts in which it is applied: it could be an order, an ironical comment over the failure of an order, the expression of a desire, a reproach and many other things. In all these cases it will be the context that can take us in the right direction. In particular, the understanding of this expression does not only require the mutual recognition of certain rules, i.e. those governing the place of each single expression as well as those of the use of orders, reproaches etc. Apparently meaningless actions such as the tone of the voice or the expression of the face, or also the prehistory of a situation will guide us towards a successful understanding. A rule cannot be recognised without some knowledge of the context in which it is applied. This may seem very banal: people understand our expressions only if they have some knowledge of the context in which that expression is situated.

What emerges here is an essentially immanent view of meaning that is at odds not only with the twentieth-century paradigm, but also with the prevalent modem view. When Wittgenstein wrote that logic cannot be described, but must be seen through practice (Wittgenstein 1969b, 501), he was not only distancing himself from his previous conception according to which sentences are pictures of facts or state of

77 Wittgenstein states that "For a large class of cases - though not for all - in which we employ the word "meaning" it can be defined thus: the meaning of a word is its use in the language" (Wittgenstein 1953, 43). Again, here he seems to mean that meaning is defined by the place in language. For an interpretation that puts more emphasis on action in use see Schneider 1999. 
affairs. He was implicitly criticising the whole modern paradigm according to which meanings are something that can be "transferred" from one mind to another"

In the third book of his Essay Concerning Human Understanding, Locke wrote: "To make Words serviceable to the end of Communication, it is necessary that they excite, in the hearer, exactly the same Idea, they stand for in the mind of the speaker. Without this, Men fill one another's heads with noise and sounds, but convey not thereby their Thoughts, and lay not before one another their Ideas, which is the end of Discourse and Language" (Locke 1688, 9, 6). Here the process of understanding a speaker's utterance is presented as a mental event occurring in the head of the hearer when he derives from the utterance the thoughts that the speaker intended to convey by it. This passage discloses a view of verbal communication that has dominated most of modern philosophy of language (Taylor T.J.1986: 172). Be it viewed as naturalistically grounded or as conventionally imposed, the underlying idea is that the meaning of a word is something that could be transferred from one head to another.

Whereas the first Wittgenstein distance himself from this view and dismissed the problem as a pseudo-problem, i.e. a problem that concerns only psychology, he went on to elaborate a view of meaning that took on board the problems that the modern view had addressed and provided an alternative answer. In this new view, meanings are not conveyed by words from one mind to another, but are constructed in languagegames. Or even better, since they are not something that is "added" to the interaction, they simply are there, immanent to any communicative action and context. It is the sharing of these latter that provides the guarantee of a possible mutual understanding.

This does not mean, though, that Wittgenstein adopts an "expressivist understanding of language". In his Philosophical Arguments, Charles Taylor distinguishes between two fundamental paradigm of language: the first is best represented by Locke and is mainly concerned with language as an instrument for the construction of our picture of the world, with its proper use and abuse, whereas the second moves from a romantic critique of this view and has Herder as its key exponent (Taylor 1995, ix). Wittgenstein, according to Taylor's reading would be an exponent of this second paradigm (Taylor1995, ix; and in particular, $66 \mathrm{ff}$ ). In fact, it can be shown that Wittgenstein's reflections on language are part of a "linguistic turn" that, by going

\footnotetext{
${ }^{78}$ The Fregean paradigm described above also distances itself from the typically modern view of the "transfer" of meanings, but, as we have seen, it does it either by liquidating the issue as meaningless or in the best case by leaving it to psychology.
} 
beyond the presuppositions of modem philosophy of consciousness, have also gone well beyond the "expressivist" paradigm and rather point to the uselessness if not impossibility of even separating the two paradigms ${ }^{79}$.

Certainly Wittgenstein shares a emphasis on language as a fundamentally social phenomenon with romantic theories such as that elaborated by Herder. And for this reason Wittgenstein, perhaps more than any other representatives of the linguistic turn, has been widely used within the social sciences. ${ }^{80}$ His view of language is a fundamentally social view, where by "social view" I do not simply mean that language is for him a social business i.e. that we need a language, we learn it, we use it because and by interacting with other people. Moving from Wittgenstein's insights, one might, for instance, argue that a human being who had never had contact with other living beings - no just with other humans, and the reason for this will be clear later on would have no language at all. Such a creature, if s/he could ever exist, would at best produce sounds, not words.

Thus, in order to have words, i.e. signs having a meaning within a language, you need to have a criterion for the correctness of their use. But any measure needs to be independent of the thing that is measured and therefore the use that one single person makes of a word cannot be the criteria for its own correctness. And it is the "social" that provides this criterion. However, with his critique of the possibility of a private language and of the possibility of ostensive definitions, what Wittgenstein does is to open the way for a view of language and meaning that departs fundamentally from the romantic philosophies of consciousness.

It is in this sense that we must also read Wittgenstein's argument against the possibility of a "private language" (Wittgenstein 1953, $243 \mathrm{ff}$ ). ${ }^{81}$ By "private language" Wittgenstein meant a language that a person could use to give expression to his own immediate inner experience without it being possible for another person to understand it. Let us suppose with Wittgenstein that, for example, I want to keep a diary of the recurrence of a certain sensation and I decide that I will write the sign " $S$ " each time

\footnotetext{
${ }^{79}$ On Wittgenstein and expressivism, see in particular Clack 1999. After analysing Wittgenstein Remarks on Frazer from the point of view of expressivism, he suggests that perhaps Wiitgenstein theory would rather go towards overcoming the distinction between expressivism and instrumentalism (Clack 1999: 129ff).

${ }^{80}$ Recently, for instance, Wittgenstein's philosophy of language has been used as the basis for developing a social psychology. On this point, see Jost 1995.

${ }^{81}$ On this point see in particular Kenny 1973, 10.
} 
that this sensation recurs (Wittgenstein 1953, 258). But how can I discern this sensation?

Of course, Wittgenstein replies, I can give an ostensive definition of it: concentrate my attention and point to it inwardly. But what can guarantee me, he further asks, that I will recognise it in the future? This is not to say that I cannot have a memory of this sensation. It rather means that I can have no criteria for the correct association of that sign " $S$ " with that sensation in particular so that whatever association will appear as right to me can be defined as "right" (Wittgenstein 1953, 258). This situation is similar to that of someone saying "I know how tall I am", and by putting his hand on top of his head believes that he has proved it (Wittgenstein 1953, 279). The point is that a measure must be independent from what it is measured thereby, ${ }^{82}$ and therefore it is impossible to control the association of " $S$ " with a certain object if it is not inserted in a public language.

By criticising the idea of a private language, Wittgenstein did not mean to deny the possibility of communicating our inner experience. On the contrary, inasmuch as we are, have been, and will be engaged in language-games where the expression of pain, anger, joy, etc. is at stake, we also learn to express our inner experience. The recognition of a common bodyliness helps this task - so that if someone in front of me is hurt by a heavy object in his body, I expect a reaction of pain. But the point is that in order to understand his expression as a meaningful expression, I must have been trained through certain language-games.

A common bodyliness is thus not sufficient to elaborate meanings. If I find myself in India and I want to express my inner disapproval at something by shaking my head left and right, I am simply playing the wrong game in that context, because Indians will take it as a sign of my approval. To be successful in communicating my feelings in that specific context I must also have some experience of it. Similarly, Wittgenstein's point is that even in order to recognise a certain meaning as an expression of my own pain, $I$ must have gone through a specific language-game training.

This, however, does not mean that since Wittgenstein puts emphasis on the embeddedness of language that he must be put together with Heidegger and other representatives of the hermeneutical turn within the romantic or expressivist paradigm (Taylor 1995, 4). The point, is in fact, how the context itself is understood and there are

${ }^{82}$ On this point see also Wittgenstein $1953,265$. 
reasons to suspect that Wittgenstein's concept of language-game entails a concept of the context that is fundamentally at odds with both Herder's and Taylor's views and thus cannot be assimilated within the romantic paradigm.

Wittgenstein's emphasis on context has indeed been often interpreted as an argument for the distinction and even incommensurability between different cultural contexts. ${ }^{83}$ If the meaning is the use and use is the context, then whenever you leave a given context you also leave that universe of meanings. But this view reflects too reified a view of the context, as it was some sort of self-enclosed unit. And this is the view to which Taylor, following in this Herder, refers. It is on the basis of this view that Taylor can, for instance, call for a politics of recognition of different cultures understood as different contexts or horizons of meaning (Taylor 1992).

However, from the point view of Wittgenstein's approach to meaning, Taylor's view of cultural contexts as singular units appears as the exchange of the egocentric for an ethnocentric point of view, i.e. solipsism on a larger scale. The concept of languagegames implies, indeed, the idea of fluid and continuously changing contexts and situations, where even the idea of boundaries can hardly be applied. The difficulty is both diachronic and synchronic. Not only there are most often many and different language-games taking place at the same time, so that it becomes difficult to identify the boundaries between them. But we are ourselves continuously within a plurality of language-games and thus contexts.

Most of the misunderstandings on this point have been generated by Wittgenstein's scattered and never fully developed identification of the language-game with what he calls "forms of life" (Wittgenstein 1953, 19, 23, 241). ${ }^{84}$ Thus for instance he wrote, "the term "language-game" is meant to bring into prominence the fact that the speaking of a language is part of an activity, or of a form of life" (Wittgenstein 1953, 23). Unfortunately, Wittgenstein never develops the concept of "form of life" and it is as a consequence very difficult to understand what he meant by this. This omission, on the other hand, has left a great deal of space for speculation and many authors have consequently interpreted this concept in over-culturalist terms.

\footnotetext{
${ }^{83}$ Rorty 1989, Von Savigny 1991 and Coulter 1999 for instance advance culturalist interpretations of Wittgenstein.

${ }^{84}$ On the problems raised by the concept of "forms of life" within Wittgenstein's philosophy, see Scheman

"Forms of life": Mapping the rough ground" (Scheman 1996).
} 
Culturalist interpretations of the identification "language-games" with different "forms of life" have also been used as an argument in favour of the incommensurability between different "cultures": if meaning is use and use is a form of life then, communication between different forms of life is deemed to be problematic, if not impossible. ${ }^{85}$ Other passages have been used to support this interpretation. For instance, at the end of his Philosophical Investigations, after saying that one human being can be a complete enigma to another, Wittgenstein continues by saying that "we learn this when we come into a strange country with entirely strange traditions; and what is more, even given a mastery of the country's language. We do not understand people (and not because of not knowing what they are saying to themselves). We cannot find our feet with them". And again, as we read few lines below, "If a lion could talk we could not understand him" (Wittgenstein 1953, 223e). Indeed, as we read in Zettel: "we do not understand Chinese gestures any more than Chinese sentences" (Wittgenstein 1967, 219).

Together with these culturalist interpretations, there have been those who, in the expression "forms of life", prefer to point to the importance of the second term - "life". According to Stanley Cavell, for instance, Wittgenstein wanted to point to the fact that it is life - and thus activity - that lies at the bottom of language- games. Therefore one can also point to a biological basis that is common to all human beings (Cavell 1979): this is what would guarantee a common background ${ }^{86}$ against which to insert any single language-game. It would be to this background that Wittgenstein was referring when speaking of a "common behaviour of mankind" (Wittgenstein 1953, 206).

We do not need to solve all the problems that these two opposing interpretations raise. The first impression is, however, that Wittgenstein could not have embraced a radical incommensurability thesis. All the same, the very idea of "forms of life" remains a fundamentally problematic concept that created more problems than it solved. Indeed, it inevitably suggests the idea of some kind of "unity" within each

\footnotetext{
${ }^{85}$ Arguments à la Wittgenstein of this sort can also be found quite often in the social sciences: see, for instance, the "ethno-methodological approach" developed in Coulter 1999. For a culturalist interpretation closely based on a reading of Wittgestein's writings, see Von Savigny 1991.

${ }^{86}$ On the importance of the concept of background see also Zettel, 567, where we read: " How could human behaviour be described? Surely only sketching the actions of a variety of humans as they are all mixed up together. What determines our judgement, our concepts and reactions is not what one man is doing now, an individual action, but the whole hurly-burly of human actions, the background against which we see any actions" (Wittgenstein 1967, 527)
} 
single form of life, i.e. something that is, on the other hand, at odds with the idea of putting acting at the basis of the concept of language-game.

Human (inter)action cannot be limited within the spheres of single self-enclosed "forms of life" - and today less than it ever was. We are able to interact not only with people from other cultures, but even with other animals of other species (Churchill, 1989). Certainly there is no guarantee that by precipitating into a strange country we will not feel the impossibility of finding our feet with them. However, this is due to our contingent lack of familiarity with these language-games, and not to an ontological incommensurability between them. Here, it is the fact that we can, if trained, learn different language-games that is most important. Maybe I do not, in the present circumstances, understand Chinese gestures any more than I do Chinese sentences, but I can, potentially, learn to understand both of them

Reversing Wittgenstein's statement, we can therefore conclude that even if a lion cannot talk, we can - and we do - understand it. Whoever has the experience of having shared an interaction context for a long time with an animal knows quite well that we do understand their "language", as well as they understand ours, because we have been participating in the same language-games. It is simply a matter of creating an interaction context and progressively entering and leaming language-games. In other words, meanings are not something we carry around with our identity cards. They are much more the result of what we do - than the consequence of what we are.

Thus, if the forms of life that lie at the bottom of language-game must not be identified with self-enclosed cultural units, it becomes even clearer that Wittgenstein's emphasis on context does not mean that he is one of the representatives of the romantic paradigm. Rather, Wittgenstein's statement that "human beings are ceremonious animals" means that he has gone well beyond the distinction between the two paradigms: if meanings are language-games, then it is, in fact, meaningless, if not impossible to distinguish between the two paradigms identified by Taylor, since in a language-game no distinction between the "designative" versus the "expressive" functions can be made. ${ }^{87}$

Going back to Wittgenstein's Remarks on Frazer's, we might recall here that, according to this text, "a whole mythology is deposited in our language" (Wittgenstein 1967b, 10e). This also implies that one cannot approach the meaning of certain

\footnotetext{
${ }^{87} \mathrm{~A}$ similar point is made by B.R.Clack in his book on Wittgenstein and Fraser (Clack 1999:129).
} 
practices and notions by looking for what they "designate" as distinguished from what they "express". This can ultimately be only a fallacious attempt at separating what cannot be separated and it reflects too a limited view of the concept of truth and meaning. Thus, according to Wittgenstein:

When we explain, for example, that the king must be killed in his prime because, according to the notions of the savages, his soul would not be kept fresh otherwise, we can only say: where that practice and these views go together, the practice does not spring from the view, but both are there (Wittgenstein 1967b).

Otherwise stated, what we have are practices and views that simply are there, together and inseparable: one does not designate, or express the other. An act of saying is thus intrinsically an act of doing. Thus, in the end Wittgenstein observes: "we can only describe and say, human life is like that" (Wittgenstein 1967 3e).

Wittgenstein did not go into the description of the "mythology" that he held to be deposited in our language. He had not written the book in anthropology whose first words he already possessed. As a consequence his remarks remained scattered and the all these notions - myth, magic and religion - remain undifferenciated. The task of the next chapters is to start to distinguish between them. 


\section{APPROACHING MYTH}

As we have seen, myths as such could not be recognised within a Christian world view because of their "deceitful" plurality of stories. However, it is precisely this plurality that characterises myth, in contrast to the idea of the sacred logos. This does not simply mean that myths are object of different interpretations, but rather that, phenomenologically speaking, myths present themselves as a plurality both of variants and of mythologems that are all legitimate in their own right.

To catch this intrinsic plurality of myth one cannot simply analyse single myths i.e. the stories that we can fortuitously collect orally or find transcribed in books. These latter are only the final product of myth, the reified traces of the working of myth. Not only is myth meaning involving language-games, i.e. an act of saying that is at the same time an act of doing and vice-versa; it is also a process - a process of continually retelling that involves a multiplicity of subjects. There are narrators, on the one hand, and receivers or potential re-narrators, on the other - without there being any possibility of tracing any sharp divide between the two.

As H. Blumenberg puts it, it is precisely in the relationship between narrators and receivers that we should look for the specificity of myth: the myth is the "Arbeit am Mythos", i.e. working of myth and at myth. Indeed, the plurality of myth is not only a plurality of mythologems, basic narration patterns centred on a character or and episode, such as the myth of Prometheus or the myth of the foundation of Athens. ${ }^{88}$ Even a single mythologem expresses itself through variants, where each single variant 
presents itself as a story that is legitimate in its own right. This is the difference between the Sacred History and the stories of myth: even if they both present variants, since it is implicit in the act of telling a story that there can be variants, the plurality of myth is both a plurality of variants and a plurality of mythologems all of them recognised in their own right. In other words, the plurality of myth is the plurality of polytheism, where there is no God advancing any pretension to an absolute truth, but rather a plurality of gods, i.e. of truths. ${ }^{89}$

The idea of working on myth (Arbeit am Mythos) stems precisely from the polytheistic vocation of myth. As Blumenberg shows, reconstructing the re-elaboration of the myth of Prometheus through the centuries, there is not one single myth of Prometheus. whose meaning is given once for all. Prometheus can thus be better defined as a mythologem, i.e. a basic narration pattern which evolves over time and which acquired new and unexpected meanings with the changing of the historical circumstances (Blumenberg 1979).

Now if the working of myth is constitutive of the concept of myth, then it is only by looking at the relationship between narrators and receivers that the specificity of myth can be caught. Following Blumenberg's insights, one should adopt an inter-relational ${ }^{90}$ approach to myth. This is to say, one should not look at single myths, by focusing on their content and their structures. This would mean reifying myth, making an "object" out of a relational process. It is at the actual life of myth that one should look, namely at the whole Arbeit am Mythos, the working at and of myth, whose traces can only be found in those reified products of this process that are the stories we read in our books.

This is clearly only one of the innumerable possible approaches to myth. ${ }^{91}$ In the face of the variety of the possible theories of myths it is useful to recall Cassirer's remarks: myth seems to work like the enchanted glass in which Goethe's Faust thought he was seeing a beautiful woman that was in fact seeing his own image (Cassirer

\footnotetext{
${ }^{88}$ In this perspective my approach differs from those who consider the definition of myth as story and that of myth as mythologem as alternative (Henry 2001). In my approach it is implicit in the very concept of myth as story that there can be more variants of it.

${ }^{89}$ On the polytheism of myth see Marquard 1979 . The idea of myth as intrinsically polytheistic was already present in Carl Schmitt, who, however, moving from the perspective of a "political theology" could not but see in this plurality a danger (Schmitt 1923).

${ }_{90}$ The terms "inter-relational", in contrast to "intersubjective" puts the emphasis on the contexts, instead than on the "subjects". As such, it points to the fact that it is in the relationships between narrators-receivers that one should look for the specificity myth. As we will see, the working of myth is such that it becomes even difficult to separate narrators from the receivers of myth.

${ }_{91}$ Particularly helpful overviews of the different approaches to myth from a philosophical perspectives are: Bohrer 1983, Jamme 1991, Jamme1999, Poser 1979.
} 
1946:5): linguists found a world of signs and names in myth, philosophers found a "primitive philosophy", psychologists a product of the unconscious. Each scholar has found in myth those objects with which he was most familiar. Faced with such a enchanted glass, one should better look at oneself, reconstruct one's own genealogy and then possibly situate it within the spectrum of other possible approaches.

The starting point of an inter-relational approach does not, for instance, coincide with that of Freud's. That is to say, although psychoanalytical considerations are part of the approach adopted here, they do not exhaust it. Simplifying things, one can say that whereas Freud, mainly interested in the general understanding of the human mind, aims at identifying its general features, an inter-relational approach instead points in the opposite direction. The aim here is thus to search for the specificity of myth, in order understand out what differentiates it from other kinds of human expressions.

Otherwise stated, if no modern thinker has perhaps made such extensive use of mythological narratives as Freud, given that the ubiquity of the Oedipus complex can be read as the ubiquity of myth, it still remains that he has done so from the perspective of an "etiological reductionism" that aims at discovering the universals of human mind. The Oedipus's complex works as a platform for explaining all the manifestations of the human mind - from religion to society, morals and art (Freud 1899, 1913). Now, this reductionism might be helpful - and even fundamental. But the approach does not say much about the specificity of myth, which is the primary object of this enquiry and which must be emphasised from the point of view of the peculiar relationship that it implies between narrator and receivers, and not for what it has in common with other forms of expression of the human mind.

Furthermore, Freud's etiological reductionism also seems to bring with it the corollary of the primitivity of myth. In particular, Freud's parallel between the mythical constructions of animism, neurotic symptoms, and the process of secondary elaboration of dreams - as developed in Totem und Tabu - reduces myth to a "primitive" phenomenon - one that concerns the "savage mind", but which is destined to be swept away by the development of abstract intellectual language: ${ }^{92}$ whereas the primitive, as the neurotic, overestimates its own thoughts over reality, civilised men, full of conscious perceptions, can separate what is "real" from what is not. Thus, behind the contrast between "civilised" versus "savage" mind we again find the separation

${ }^{92}$ This is suggested at many points in Totem und Tabu (Freud 1913). 
between "thinking" and "reality", which is one of the fundamental presuppositions of the Enlightenment and which should therefore be overcome if one does not want to risk falling once more into the dialectic of the Enlightenment.

Freud's analysis of mass psychology is also linked to his general etiological reductionism. In particular, the analogy he put forward between the neurotic's overestimation of his own mind in relation to reality and the primitive mind of primitive peoples reflects the attempt to analyse the problems of a psychology of peoples with the tools of the individual psychology. This is recognised as problematic by Freud himself, for it presupposes something like a "collective soul" (Freud 1913,7) which creates more problems that it seems to solve.

When Freud deals extensively with the issue in his Massenpsychologie und Ichanalyse (1921), he points out that psychoanalysis is already a social psychology inasfar as it cannot analyse individual minds without taking into consideration their relating to others (Freud 1921,1). However, as he points out later on, the others that are taken into account are those encompassed in the pre-given and limited plot of the individual's complex (Freud 1921, 1), whereas mass psychology considers the way in which being the member of a mass - a race, a people, a social group or class, etc. - affects an individual's behaviour. Freud moves to this ground through the analogy "mass" = "undisciplined infant" = "passionate savage", which suggests a reified view of social groups as homogeneous entities. But the always possible unity of the infant's mind is different in comparison with the fundamentally problematic unity of a mass, ${ }^{93}$ so that if we want to find out what kind of relationship is entailed in the narrators-receivers relationship, we cannot assume it as given from the beginning. ${ }^{94}$

As a result, the inter-relational approach also differs from structuralist theories of myth. As Claude Lévi-Strauss makes clear at many points in his work, the aim of structuralism is no different to that of the "hard sciences", since both are moved by the "quest for the invariant". ${ }^{95}$ In Lévi-Strauss's view, structuralism would allow the contrast between the scientific positivism of Durkheim and the historical particularism

\footnotetext{
${ }^{93}$ For a critique of the analogy between personal identity and the identity of social groups see Chapter $11.0 \mathrm{n}$ the concept of group identity as a "problematique", see Wagner 2002.

${ }^{94}$ The approach here adopted also differs from other psychoanalytical approaches to myth. For instance it differs from Gustav Jung's approach: here, the focus is that of an inter-relational approach is the specificity of the myth as a relational process, and not the universal truths of the archetypes expressed in all kinds of human expression - poetry, rituals, totemic practice, etc. - as described by Jung.
} 
of the cultural anthropology of F. Boas - the two approaches to social sciences which most influenced him - to be overcome. In this view, Durkheim was right in asserting the existence of the universal invariants of the human society, but these should not be looked for in what different cultures superficially seem to have in common, but rather in the systematic relationships between those cultural differences - as they have been emphasised by cultural anthropology. In his view, this can be done by applying Jakobson's linguistics to anthropology. According to Jakobson, the structure of a language consists in the system of differences occurring between its terms: the invariants are thus not to be identified with superficial resemblances, but rather with the invariance of the hidden relationships. Lévi-Strauss called these constants the "structures of the human spirit", and claimed they were to be found not only in verbal utterances, but in all sorts of symbolic systems: totems, masks, rituals, and all kinds of cultural expressions - from totemic practice to cooking and music (Levi -Strauss 1958, 1987).

Lévi-Strauss's theory of myth also seems to comprise an approach concerned with outlining the working of universal structures of the human mind rather than with defining the specificity of myth. It comes as no surprise, therefore, when Lévi-Strauss maintains that there is a close "similarity" and "contiguity" between myth and music a theory for which he was strongly criticised. By similarity he meant the closeness of structure between the two and by contiguity, the fact that the point at which myth passed into the background in Western thinking - that is, during the Renaissance and the seventeenth century - corresponds to the emergence of the great musical styles (Levi-Strauss 1964, 1965). As to the first point, one may object that the fact that he was able to identify the same structural invariants in such different fields might well be the result of the fact that the same invariants can be found everywhere for they are the product of the same mind which is now trying to "discover" them. What he treats as "objects" are in fact human products, that is to say products of the same mind that is now trying to analyse them as if they were not its own product.

On the other hand, his view of the contiguity between myth and music also reflects the same dichotomic approach that we have seen in Freud, and which aims at classifying myth as a product of the "savage mind" destined to be swept away by

\footnotetext{
${ }^{95}$ See for instance his 1977 interview where he clearly asserts that the structuralism in the field of linguistics, or anthropology and the like is nothing other than a very pale imitation of what the "hard sciences" have been doing all the time (Levi- Strauss 1978:9)
} 
scientific rationality. He sometimes seems to push the dichotomy as far as to "naturalise" it through the argument of the mutually exclusive capabilities of the human mind. In a significant passage, Lévi-Strauss suggests that "primitive thinking" and "civilised mind" rely on two different sorts of mental capacities and that these capacities cannot be developed by the same mind at the same time. This is, in his view, a necessary consequence of the fact that humans can use only a small sector of their mental capacities, and that therefore each culture and each stage of human evolution has to develop its own sector (Levi-Strauss 1978:19). ${ }^{96}$

However, such a dichotomic approach is unable to explain why myth has survived over time despite and next to scientific rationality. How can we explain this? LéviStrauss's approach seems unable to handle the issue because he approaches myth from the perspective of its having to be overcome by the same forces of scientific rationality through which he himself tries to catch the invariants of myth. Thus he too remains entrapped in the dialectics of scientific logos which tries to distinguish itself from myth by charging it with the accusation of subjectivity. As he puts it: "Myth gives man, very importantly, the illusion that he can understand the universe and that he does understand the universe. It is of course only an illusion" (Lévi-Strauss, 1978:17). In his view, the most important difference between the ambition of the savage mind to achieve a total understanding of the universe and scientific thinking is that the first does not succeed, because only science can provide any real mastery over nature. What remains of myth is thus only illusion.

The only way to try to avoid the dialectic of the Enlightenment, which legitimises itself by charging myth with subjectivity but it turns itself into myth, seems to be by leaving the issue of the reality of myth open. This does not mean that myth is real and objective; rather, it means to taking some distance from the scientific view of myth as fanciful stories and, consequently, leaving the issue of the "reality of myth" between parentheses, which means, in its turn, suspending the question of the correspondence of its contents to "reality".

\footnotetext{
${ }^{96}$ For criticism of Lévi-Strauss's ethnocentrism, see in particular Geertz's "The Uses of Diversity" in Geertz 2000. As Geertz observes the problem with ethnocentrism is not that it commits us to our own "cultural" commitments, but rather that it impedes to us from discovering at what sort of angle we stand to the world. In particular it obscures the fact that foreignness does not start at the water's edge but at the skin's (Geertz 2000: 76).
} 
Thus an inter-relational approach to myth is also a phenomenological approach. What characterised the phenomenological method, as first elaborated by Husserl, ${ }^{97}$ was precisely this intention to put the question of realism between parentheses. Since we do not have the means to determine whether our representations of the world correspond to the world as it is "in itself' (if this expression has a meaning), phenomenology chooses to leave this question aside and to examine the way in which our consciousness relates to the phenomenological world - no matter whether this latter corresponds to a supposed world in itself or not. ${ }^{98}$

In this sense, phenomenology was defined as a "return to the things themselves", by which Husserl meant that these latter are phenomena, understood not as appearances counterpoised to hypothetical things in themselves, but rather as original disclosing of "reality" in consciousness (Husserl 1901). The aim of the phenomenological method is, then, to describe phenomena "as they are given in the consciousness" in order to grasp its pure form or idea (eidos). It therefore requires a preliminary "reduction" through which all common judgements are suspended, which is what Husserl called phenomenological epoché. This means that all theories - ranging from scientific theories to judgements of common sense - are placed between parentheses. Among these theories, Husserl includes naive realism, which is a belief in the existence of an "external" world that should be faithfully reproduced by consciousness (Husserl 1912).

To adopt a phenomenological approach to myth means, fundamentally, to explicitly move from an epoché over the question of the "reality of myth". In other words, one should not consider the myth's entertaining a certain relationship with reality - be this correct or not - as being constitutive of it. By raising the issue of the reality of myth, one risks adopting a pre-given conception of reality. On the other hand, it is a phenomenological starting point that is combined with an inter-relational approach.

\footnotetext{
${ }^{97}$ Reference is made here to the phenomenological method developed by the early Husserl (Husserl 1901, 1912). Insights are drawn from this early Husserl and not from the idealistic turn of his later writings, which is particularly clear in the series of lectures given in Paris in 1929, published only after his death (Husserl 1950).

98 It might appear as bizarre an appeal to a phenomenological method following a Nietzschean genealogy. Phenomenology, in Husserl sense, is characterized by the recommendation to prescind from what lies "behind" our representation of reality, whereas Nietzsche's genealogy of morals might be interpreted precisely as an attempt to look at what lies behind our moral judgments. However, if one takes the phenomenological method in its most radical sense, one should recognize that there is no "behind". Even if a "behind" existed we would know nothing about it, and it is therefore meaningless to suppose something that cannot be known.
} 
This primarily means that the emphasis is placed on relationships, and thus on contexts, rather than on consciousness.

What is a myth, then? Moving from the approach sketched above, there are at least three features of the working of myth that can be emphasised. The most general is that the working of myth takes place within a network of symbols. In a sense, then, a myth is a symbol - or better - it involves a network of symbols. But while all myths are symbolic, not all symbols are, on the contrary, myths. Indeed, although symbols are everywhere, at least wherever there is language and communication, myths are not. We need more than a symbol in order to have a myth.

Keeping the two categories of myth and symbols analytically distinguished is crucial. In avoiding the Scylla of neglecting myth, we must not fall into the Charybdis of mythologysing everything. To distinguish myth from symbols is necessary in order to distinguish myth from all the other symbols that are not myths. For instance, both rationality and myth rely on symbols, but they do so in a different way. Indeed - and here we approach the first feature of myth - a myth differs from rational argumentation because, despite the fact that both operates with symbols, myths operate with figurative means: a myth is made of images, figures and characters. This is a first feature of myth, which differentiates it from all other kinds of symbols in general and from rationality in particular.

This does not, however, mean that, following the self-presentation of the Enlightenment we must understand myth and rationality as mutually exclusive. It simply means that the two categories must be analytically distinguished if we want to capture the specificity of myth. Myth is not incompatible with rationality, but at the same time it does not coincide with it. Indeed, a string of numbers in a mathematical proportion is a series of symbols, but nobody - or at least only a very few - would argue that it is a myth. Thus, it is not in the category of symbols that we must look if we want to find the specificity of myth

The conflation between myth and symbol stems, perhaps, from a further conflation between two different mainstream meanings of the term "symbol". In a broad sense, a symbol is simply a sign for something else. This is the original meaning of the Greek word synbolon, stemming from the verb synballo, "to put together". It originally designates the two halves of a broken object that can be recomposed only by putting them together: in this way each half is a sign referring to something else. However, the 
term acquired a further meaning over time. In a more restricted sense, a symbol is a special kind of sign, i.e. it is a sign that is indeterminate, referring to some hidden or remote reality. In this sense, we say, for instance, that a symbol is a sign with an equivocal meaning.

The concept of symbol has been the subject of much of philosophical speculation. The first philosopher to take precisely "symbol", and not some other related concept such as "sign" or "meaning", as the key concept of a philosophical system was E. Cassirer. According to Cassirer, symbols are the transcendental conditions of human thinking because they are the only means through which meanings are possible. As we read in the Introduction to his Philosophy of Symbolic Forms, the symbolic function is the fundamental function of our consciousness, the function through which only the activity of human consciousness is possible. Consciousness, according to Cassirer, is nothing but a "pure form of referring" i.e. each single content of the consciousness is interwoven in a net of relationships, and it is through this net that a content, in its simple being, implies reference to other contents (Cassirer 1925, I, Introduction, 4; trans. mine). Symbols are thus the products of this original activity of consciousness.

In Cassirer's view, therefore, every significant realisation is a symbol. In a symbol, the sensitive element - a written sign, a sound, an image etc. - presents itself, simply on account of its being, as both differentiation and materialisation, i.e. as the manifestation and incarnation of a meaning (Cassirer 1925, IIIa, part I, ch.3). It is therefore unnecessary for the two elements, the sign and the object referred to by the sign, to be already known as separated in order to have a symbol. On contrary, according to Cassirer, it is precisely through conceiving the "image" and the "object" as separate that the "expressive" can be distinguished from the "conceptual" function. Whereas in the pure phenomena of expression, there is no "skin" or "core", no "one " or "other", because even if the expression is an exteriorisation, in this exteriorising we are still in the interiority, with conceptual knowledge the representation and the object of the representation are posed as clearly distinguished.

These are in Cassirer's view, the two fundamental forms of consciousness, to the analysis of which he devoted most of his thinking. He also went further in this and identified the expressive form as the basis of the lower formations of the consciousness, or "mythical consciousness", and the conceptual form as the basis of scientific consciousness. Myth, in his view, is thus a form of the expressive experience 
that is primitive precisely because the consciousness is here completely absorbed (überwältigt) by the object of his representation, without it being possible to clearly distinguish the sign (Zeichen) from the object designated by it (Cassirer 1925).

As has already been observed, this approach to myth somehow presupposes scientific rationality as a terminus ad quem. ${ }^{99}$ Myth is here characterised as inferior precisely because it is assumed that it must be superseded by scientific rationality, with which only, in Cassirer's view, a clear distinction between the representation of consciousness and its objects can be realised. However, as we have seen, the separation between the "object" and the "subject" of representations is the result of a selfpresentation of the scientific logos, which risks falling into the dialectic of the Enlightenment.

The only way to try to escape this dialectic is to analyse myth autonomously. Suggestions in this direction can be drawn from Giambattista Vico, the first modern thinker to dedicate systematic thinking to myths. In his polemic against Descartes' rationalism, Vico supported the rights of fantasy and rhetoric and contested the idea of a unique "scientific method". By appealing to the principle that we can only know the truth of what we ourselves are the authors (verum ipsum factum), he claimed the need for a "new science" of human history. It was to this project that he dedicated most of his life. La Scienza nuova represents the science of the human world, a world that is contructed by human beings and whose knowledge is therefore assured by the very fact that the subject of knowledge is also at the same time the maker of this world. Thus, it is in the human mind itself that the principles of this new science can be found. And the human mind, in Vico's view, is characterised by the great part played in it by the fantasia, understood as an autonomous faculty and upon which, in its turn, the autonomy of the "scienza poetica" rests.

Two prejudices, Vico argues, have prevented human beings from recognising this autonomy: the boria dei dotti (Vico $1744,59,127$ ) and the boria delle nazioni (Vico $1744,53,125,126)$. One the one hand, there is the boria of the nations, all of them pretending to have discovered "tutti $i$ comodi della vita umana" (Vico 1744, 125) and therefore tracing back to some remote epoch of their past the origins of all that they hold as valuable in human life. The narrative of the birth of philosophy as the act of baptism of "Westem man" is a very good example of this boria. Vico's argument

${ }^{99}$ See in particular Blumenberg 1979, I, 1. 
against the boria delle nazioni can thus also be used an argument against "enlightened" readings of myth such as that developed by Cassirer: myth, Vico contends, must be analysed in its autonomy and not in the perspective of rationality as terminus ad quem.

The second prejudice hindering an autonomous understanding of myth is the boria dei dotti, " $i$ quali ciò che essi sanno vogliono che sia antico quanto che il mondo" (Vico 1744, 127). According to Vico even those who have not rejected the rights of myth and fantasy against rationality have often fallen into the opposite prejudice, i.e. that of presenting myths as the fount of some remote and ancient sapientia of which they themselves were the heirs. Vico's polemic was here directed against all those neoplatonist readings that, by means of allegory, aimed at recovering some sort of "hidden" sapientia of ancient myths.

Vico's criticism towards the boria dei dotti is also used as an argument against the continually recurring "romantic" approaches to myth: those who present myths as the deposit of a lost past are not recognising the autonomy of myth, that is the autonomy, as Vico taught us, of a continuously operating faculty of human mind. To conclude, two dangers must be avoided if we want to recognise the autonomy of the "sapienza poetica": the rationalistic disdain for what preceded the rise of scientific rationality, but also the nostalgic attempt to "discover" the origins of a lost "sapienza behind ancient "favole"".

It is through this attitude toward a "new science" that Vico's polemics against his time still provides crucial insights for an understanding of myth. Vico, who spent all his life in the Spanish and then Borbonic Naples of the eighteenth century, lived at the margins, both temporal and spatial, of modernity and was thus perhaps in the best position to perceive its limits. However, he still remains a child of his time and, therefore, even if he criticised the pretensions of the emerging scientific method, he did so while accepting at least some of the terms in which it had posed the question.

In a sense, then, Vico's theory of the sapienza poetica also partially reflects an "enlightened" attitude towards myth. In particular, his theory of the tre eta through which all the nations must pass - età degli dei, l'età degli eroi e l'età degli uomoni reflects a teleological scheme where myth, which corresponds to the età degli eroi, also appears in the perspective of rationality as the terminus ad quem. This corso of human history reflects a truth that Vico derives from what he takes to be the corso of the development of the human mind. The theory of the three stages of development of 
humanity is constructed via an analogy with the development of the human mind: "Gli uomini - Vico sustained - dapprima sentono senza avvertire, dappoi avvertiscono con animo perturbato e commosso, finalmente riflettono con mente pura". The development of the human mind is, thus, characterised by the fact that reason is the last faculty to be developed, after the senso and the fantasia. La sapienza poetica, thus, corresponds to an early stage of development both of human mind and the "corso storico".

In other words, Vico vindicated the rights of myth and poetry against those of science, but in doing so remained entrapped in a dichotomic approach of myth versus rationality, which is presupposition of the Enlightenment itself. Thus, on the one hand, Vico claimed the rights of myth and consequently the necessity of a "logica poetica", not only because poetry and myth, which Vico uses synonymously, ${ }^{100}$ are recognised as forming the origins of the language, ${ }^{101}$ but also because Vico claims the "truth of myth". Vico seems to push his claim to the point of vindicating, through an audacious etymology, the view that myth is the "vera narratio, o sia parlar vero" (Vico 1744, 400). On the other hand, he also claimed these rights from the point of view of a truth that must be recovered against rationality and in so doing he accepted the selfpresentation of scientific rationality and, in particular, the idea that myth and rationality are mutually incompatible, i.e. the presuppositions of the dialectic of scientific rationality itself.

All the same, both Vico and Cassirer remain the starting point for any reflection on myth, as both have caught the first and perhaps most basic feature of myth. Myth, they argue, is a form of poetic expression. Myth, like poetry, relies on figurative tools and this is what primarily distinguishes it from other symbolic forms. All the same, we must not draw from here the conclusion that myth and reason constitute two mutually incompatible faculties, one preceding the other. This is only to say that a myth, in contrast, for instance, to rationality, evokes images and figures.

Neither does this mean that a myth necessarily implies heroism. Indeed, whereas for Vico, who identifies myth with the language spoken in the "età degli eroi", myth is a language where "si parlò per imprese eroiche, o sia somiglianze, comparazioni,

\footnotetext{
${ }^{100}$ On this point see Cantelli 1986, I.

${ }^{101}$ The point is raised in many points of the Scienza nuovaand is based on an analysis of the way in which human mind develops. For instance, in paragraph 34, we read "I primi popoli della gentilita, per una dimostrata necessità di natura, furon poeti, i quali parlaron per caratteri poetici" (Vico 1744, 34).
} 
immagini, metafore e naturali descrizioni" (Vico 1744, 32), we should not reduce myth to a language that expresses itself only through the narration of "imprese eroiche". If we do not accept the teleological scheme implicit in Vico's theory of the "tre etă", there are no reasons why we should identify myth with the stories of heroes and heroines. ${ }^{102}$

On the contrary, the history of myth shows that everything can be the object of a mythical narrative. We do not need princesses to be saved or dragons to be killed in order to have a myth. This is its second crucial feature: the working on myth can operate with different possible contents. This means that no particular kind of content can be considered as defining of myth. Myths do not only have to do with stories of imaginary gods, heroes and undertakings -as an enlightened approach would expect. The content of mythological narratives has changed continuously over time - ranging from the Greek stories of gods and heroes to the Nazi myth of races. Given such a clear versatility, there is no reason to presuppose that the contents of myths will crystallise and that the past contents of myths will remain as their contents forever. On the contrary, myths have revealed to be extremely flexible and capable of carrying very different contents.

This is a crucial point. The reason why so many people today still maintain that the myth has to deal with stories of gods and heroes is perhaps due to the fact that these are the myths with which we are more familiar. Stories of imaginary gods and heroes are the myths that even an Enlightened approach, caught as it was in its dialectic, was prepared to recognise as such. It comes as no surprise if most of the literature on myths deals with "primitive myths". Rather, the fact that so many myths were "found" among the "primitives" could work as further confirmation of the self-presentation of scientific reason.

On the other hand, thinking of myth as the product of the "savage" or "primitive" mind has impeded to see the myth that we - civilised, clothed white human beings "live everyday by" (Migdley 2003). And this is a problematic attitude which, as we will see, can open the way for the affirmation of myth in its most dangerous form, i.e. the myth without any possible mediation (Blumenberg 1979). Instead, one should start from the assumption of a possible banality of myth.

${ }_{102}$ Various authors have followed Vico on this point See for instace Henry 2000, 2001 and Passerini 2003. 
Therefore, to sum up, myths are made of images and figures: they rely on figurative tools but they do not necessarily do so at the service of any particular "heroic" content. To put it rather crudely, we do not need primitive blood rituals in order to have a myth. Rather, everything can be an object of myth just as everything can be an object of poetry. However, although myth - like poetry - evokes images and figures, poetry and myth do not coincide. Lyrics, for instance, are not myths - at least not necessarily. In fact, and here we move to the third feature of myth, myths are a particular kind of poetry: they are narratives.

What is a narrative? On a very basic level, narratives are sequences of events, where the idea of sequence already implies that it is by being inserted in a narrative that events are given a certain meaning. ${ }^{103}$ By sequences of events, on the other hand, I do not mean sequences of facts. Many authors have defined narratives as series of facts, where the term fact is understood as a description of what has actually happened. According to Labov, for instance, narrative "is one method of recapitulating past experience by matching a verbal sequence of clauses to the sequence of events which (it is inferred) actually occurred" (Labov 1972:359-60).

This is still a widespread view of narratives ${ }^{104}$ and it is rooted in the work of the Russian formalists of the beginning of the twentieth century - in particular, Propp and Tomashevski (Tomashevski 1925). More recently a similar view has been used by French structuralists such as R. Barthes (Barthes 1977). The basic idea here is that we can distinguish the narrative (sjuñet, discours or recit), i.e. the plot, as the organisation of facts from the story (fabula, histoire), i.e. the mere set of brute facts. According to Tomashevski, "the plot is distinguished from story. Both include the same events, but in the plot events are arranged and connected according to the orderly sequence in which they were presented in the work [....] in brief, the story is the «action itself», ... [whereas the plot] is how the reader learns of the action " (Tomashevsky 1925: 67).

Thus, this approach presupposes the possibility of separating events -understood as facts, actions - from their organisation. However, it can certainly be argued that the distinction between the two is fundamentally problematic because there is no such a thing as a "brute event". An event is such inasmuch as it $e$-venit, i.e. it becomes

${ }^{103}$ On the concept of narrative and, in particular, on the distinction between historical and mythical narratives, see also Chapter 10. 
perceivable against a background, namely it becomes "something" out of a bulk of non-becoming events that remain in the background. Therefore an event is always already organised because, inasfar as i.e. it $e$-venit against a background, this already presupposes a choice. In this sense events are always already organised. First, because they become instead, of remaining in the grey background of non-becoming events. Second, because they become in a way rather than another. Indeed, we all have experience of the different ways in which an event can be told: not just in what is not allowed to become, but also in the fact that it is made to be in that way and not in another - these operations imply a choice as well as the organisation of what is chosen.

Further, what the event becomes for the narrator, is not yet the event that it becomes for the reader. We face here the limits of any approach that focuses only on the "content" of narratives. A narrative is not a container into which the narrator puts meanings that are thereafter delivered into the mind of the receiver. Any narrative presupposes a context within which it becomes meaningful, i.e. within which it only becomes a narrative. This context can better be described as a language-game made of acting and saying and in particular of "acts of telling" and "acts of interpreting" the narrative - where it is difficult to distinguish the two moments.

Most of the structuralist studies on narrative are devoted to the search for the structural elements of which a narrative is comprised, i.e. for that surplus of meaning that makes an ordered plot emerge from a set of brute facts. To this end many scholars have distinguished structures that are narratives from others that are not. For instance, according to Barthes, we must distinguish between cardinal functions (or nuclei) and catalysers (Barthes 1977:93-4). Catalysers "merely fill in the narrative space" whilst cardinal functions fundamentally alter the status quo and they do so by providing an order to the events. Therefore, according to Barthes, while "catalysers are only consecutive units, cardinal functions are both consecutive and consequential" (Barthes 1977:94).

However, in this search for the structural nuclei of the plot in a narrative, what gets lost is the role that the reader play and, particularly, the role that s/he plays in the language- games that give meaning to a narrative. A narrative is not a narrative if it is not narrated to someone, and this someone, the reader, is never a passive receiver. As

\footnotetext{
${ }^{104}$ For instance, in Cohan and Shires we read "the distinguishing feature of narrative is a linear organisation of events" (Cohan and Shires 1988:52-53) or in Tolan: " a minimalist definition of narrative might be: a perceived sequence of nonrandomly connected events" (Toolan 1988: 7)
} 
the phenomenology of the act of reading proposed by the so-called school of Konstanz has demonstrated, the analysis of the act of reading shows that the readers are fundamental in the construction of meaning of the events narrated (Iser 1976). ${ }^{105}$ For instance the reader will typically tendentially provide logical connectives that link one sentence to the other, when they are missing.

This is not to say that the elements that the narrator includes in the narrative are irrelevant for its meaning. In trying not to overemphasise the act of producing the narrative, the opposite mistake of overstressing the act of reading should not be made. It is by combining of the two that a (meaningful) narrative is constructed. And the degrees and modality of this combination varies from text to text and from context to context. For instance what characterises a piece of art is its higher degree of indeterminacy, which fosters a more active participation on the side of the reader. This is what is at the basis of the asserted polysemy of the work of art (Gadamer 1960).

Something similar happens with myth. Indeed, not all narratives are myths. There is something in the Arbeit am Mythos, namely the process of telling-receiving and retelling of myth that distinguishes it from other kinds of narrative. In particular, a myth is a narrative that provides not just meaning, but also significance by placing events in a more or less coherent plot. The working on myth is thus also the working on the significance. The task of the next chapter is to investigate this point further.

\footnotetext{
${ }^{105}$ On the relationship between the so-called "theory of reception" and in particular Jauss and Iser and Blumenberg's concept of Arbeit am Mythos, see Leghissa 2002:27.
} 


\section{NAMING THE UNKNOWN, GROUNDING SIGNIFICANCE}

Both Cassirer and Vico have approached myth from the point of view of scientific rationality as the terminus ante quem. For this reason, Blumenberg observes, they have fallen once more in the enlightenment narrative of a passage "from mythos to logos" and have thus at least partially failed in their attempts to theorise myth in its autonomy. A much more promising approach would seem, instead, that of looking at myth from the point of view of what it follows, i.e. analysing myth as a terminus post quem (Blumenberg 1979, I, 1). Thus, instead of approaching myth in terms of what it serves as a "preliminary" substitute for, i.e. science, one should rather look it from the perspective of what it follows, i.e. at what it serves to overcome.

The basic performance of myth is to provide names. A myth is always "the myth of...". That is to say, that the prerequisite of any myth is to give names to things. It is only by giving things a name that they can become "graspable" and can therefore become the object of a story. Providing names does not only render stories possible; naming the unknown is already a way by which to dominate it. Denominating a thing is the first - if not the most interesting - answer to the question "What is this or that?". Moreover, by giving a name to the unknown, a whole net of other meanings are recalled. $^{106}$

In replying to Phaedrus' question "What is the soul?", Socrates says that he cannot say what a soul is in itself. This is the task, he admits, of a divine exposition in every sense. On the contrary, to say "what it resembles" is a perfectly human task (Phaedrus, 246A ff). The soul, Socrates states, is a chariot. A chariot has horses and a

\footnotetext{
${ }^{106}$ Cassirer, as we have seen, has insisted on the concept of symbol as an unlimited net of references. Today the same claim is advanced by the semiotics developed by U. Eco 1974.
} 
charioteer. The charioteer represents the nous, which guides the two horses: one black, made of opposites, and one white, which is good and beautiful. To lead the chariot is, therefore, inevitably very difficult. The image of the chariot is extremely powerful and generates a whole myth: each chariot aspires to follow its respective god in the hypenuranion in order to see to the "land of truth", but because of its mixed composition, it is destined to fall and lose its wings. It is only through contemplating beauty that the charioteer can dominate the black horse and let the wings of the soul grow again (Phaedrus 256a ff).

Modernity, Blumenberg observes, is perhaps the epoch that has gone the furthest in providing names and, in a sense, it can thus be defined as the epoch that has found a name for everything. It is no coincidence therefore, according to Blumenberg, that Francis Bacon connected the recovery of Paradise with the rediscovery of the original name of everything (Blumenberg 1979 I, 2). Bacon perceived the power of nomenclature clearly: it was manifest to him that it is only by naming and classifying the world that the bases for its mastery can be laid.

To name the unknown is thus not only to render familiar the unfamiliar. It is also a way of providing a means for orientation. Names are meanings and meanings are meanings in contexts of meanings: they recall other meanings and, in doing so, they provide a whole web orientating action. The sovereign can thus be defined as s/he who has the power to impose names. $T$. Hobbes observed that however ingenious all other human inventions are, there can be no comparison with the invention of what he calls "speech". This latter, defined as "consisting of Names or Appellations and their connection" is the means by which human beings "register their thoughts, recall them when they are past, and also declare them one to another for mutual utility and conversation" (Hobbes 1651, I, 4). Thus defining things and their reciprocal connections is the sovereign's function par excellence. The first "author" of names, Hobbes also observed, was God, the omnipotent God of Christians (Hobbes 165, I, 4).

According to the narrative of the Genesis, God dominates the world because he created it with his words (Genesis I, $1 \mathrm{ff}$ ): at the beginning, earth was formless and empty, but God said «Let there be the light, etc...», and by naming the things of the world he created them. ${ }^{107}$ God also created the human beings and he created them in

\footnotetext{
${ }^{307}$ For a discussion of this passage of the genesis, see chapter 2.
} 
his own image: as God created the world by naming it, it was through the power of imposing names that the mastery of the world was given to "man".

"Now the Lord had formed out of the ground all the beasts of the field and all the birds of the air. He brought them to the man to see what he would name them; and whatever the man called each living creature, that was its name" (Genesis II, 20).

Names are not just the means by which webs of meanings are created and the world therefore mastered. Names are also reassuring in themselves: they fill up an empty space. Ancient poetry was full of long lists of names. Blumenberg observes that the reason why we now find these long lists of names "unpoetical" is that we live in an epoch, that of modernity, which aspires to give a name to everything and it is therefore overwhelmed by names (Blumenberg 1979).

All the same, the traces of this "filling-up" power of names can still be found in the long lists of names spread throughout ancient texts such as those of Homer and Hesiod, and the Ancient and New Testaments. The function of these long lists was to reassure about the familiarity of the poet with what he was narrating: no empty space is left, because the poet has a name for everything. Any biblical figure, thus, for instance, provided an occasion for an outburst of names, cast in the form of their genealogies. These genealogies were not only aimed at delineating a continuity of a story. Sometimes names that appear were not mentioned either before or after in the story. They play no other role in the story - apart from just being there. This happens not just for the genealogies of the great figures of the Old Testament - see, for instance, Adam's (Genesis V, 1) or Abraham's genealogy (Genesis XI, 10). Aso Christ's genealogies ${ }^{108}$ in the New Testament are full of names that have no sequitur or prehistory: they simply are there - filling up a space.

We need names to master the world, because we need names to master the emptiness. Emptiness generates fear - fear for something but also anguish (Angst) ${ }^{109}$, i.e. the fear without any object. As Blumenberg observes, a fright that has found again the word is a fright that is already over (Blumenberg 1979). Magic manifestly exhibits

\footnotetext{
${ }^{108}$ See in particular the genealogy of Christ provided in (Matthew I, 1-16)

109 In his essay on Blumenberg, Robert Wallace observes that the term "Angst, which is usually translated with "anxiety", would be better rendered in English by the psychiatrist's paraphrase "intense fear or dread lacking an unambiguous cause or specific threat" (Wallace 1984:95)
} 
the exorcising power of names. Anguish generated by the unknown can be dominated by pronouncing the right word: magical words do not only evoke hidden forces, they also exorcise them. By pronouncing names, the empty space of the unknown can be filled and - through this fullness - can be mastered.

Anguish (Angst) refers more generally to the horizon of the empty possibilities that can present themself. As Blumenberg points out by recovering a fundamental Freudian insight, anguish is never realistical: it is never commensurate to the perception of determined peril. Anguish has no object. Therefore, according to Blumenberg, it is always pathologic. Those who are prey to anguish are those who have lost the possibility to "put something forward", i.e. to mitigate the absolute power of the unknown. Therefore those who can name things, so Blumenberg continues, have a first powerful means by which to fight the "absolutism of reality" and have thus already gone beyond the threshold of this absolutism (Blumenberg $1979 \mathrm{I}, 1$ ).

Blumenberg defines the "absolutism of reality" as the condition in which human beings come close to losing control over the conditions of their existence, or, what is more important, they believe that they lack any control over them (Blumenberg 1979 I, 1). The concept of the absolutism of reality, he also observes, is corroborated by theories of anthropogenesis. These latter depict the initial situation of humankind in terms of exit from the pluvial forest. The abandoning of the forest led to the humans' definitive acquisition of an erect position, which in its turn implied a widening of their horizon of perception. Thus, this erect being, who abandoned the advantages of a hidden way of life for those of the savannah, was obliged to face the challenges of a widened horizon of perception and visibility: it is this being that had to face the absolutism of reality (Blumenberg 1979 I, 1).

Blumenberg was here clearely influnced by the ideas of the German philosophical anthropology, as elaborated by Max Scheler and Arnold Gehlen. According to these, human beings, in contrast to animals, have not adapted to a specific environment and are therefore weltoffen (Scheler). This has two basic consequences. First, according to Gehlen, human beings are subject to all sorts of stimulations and impressions from the outside world, what places a great burden on them from which they must seek relief (Entlastung). The set of devices and apparatus by which they can obtain relief is culture, which therefore constitutes a sort of "second nature" (Gehlen 1950). 
From these remarks derives a second consequence: to have a world is always the result of an art - even if, to use Blumenberg's words, the world can never be a total work of art (Gesamtkunstwerk) (Blumenberg 1979). The means through which all these actions, aimed at providing relief, takes place is language and thus meaning. Myth, according to Blumenberg, together with magic, science and metaphysics, among others, is one of the possible means for obtaining such relief (Entlastung).

As Blumenberg has noticed, there is a functional analogy between myth, science and metaphysics: by naming the unknown they all contribute to its mastery. (Blumenberg 1979, II, 2). As we will see, this does not mean that there is no difference between them. It simply means that, as Blumenberg again observed, myth defined a standard of performance that metaphysics and science could not fall short of satisfying.

Blumenberg thus also follows Gehlen in his reference to theories of anthropogenesis, deriving the image of a primordial condition of humanity from them that he mixes with the old philosophical tradition of the status naturalis (Blumenberg $1979,1,1)$. The "old state of nature" is here presented as philosophical devices, i.e. as a limit concept, but nevertheless doubts can still be raised over the helpfulness of such a reference.

In fact, as Blumenberg seems to suggest in many places, whatever starting point one takes, the work of demoliting the absolutism of reality has always "already started" (Blumenberg 1979). We are always beyond the threshold of this absolutism. There seems, therefore, to be no need to call on the state of nature, a category that might be misleading from a number of points of view. In particular, the idea of a status naturalis cannot but evoke its normative corollary: the need to enter into a status civilis. In whatever way one presents this state of nature, something is always presupposed by the very fact that it is a natural state: i.e. human beings must leave this condition and enter a civil(ised) one.

Blumenberg was here probably influenced by Gehlen's view of man as a Mangelwesen. According to this, human beings are not naturally assigned to a specific environment and are therefore incomplete beings in comparison with other animals. Precisely because of their incompleteness, they must undergo a process of disciplining: the Mangelwesen is also a Zuchtwesen (Gehlen 1950).

The Entlastung from the excess of impulses to which human beings are subject because of their incompleteness is reached, according to Gehlen, in two basic ways. 
First, human beings distance themselves from the immediacy of drives and move on to the level of symbolic and intellectual action. Second, they seek-an Entlastung through the mediation of institutions: these latter, by mediating the relationship of man with his needs provide man with a stable horizon (Gehlen 1950).

Many authors have criticised this conception for its political implications and have seen in it the sign of Gehlen's connections with the authoritarianism of the Nazi regime. However, the idea of human beings as weltoffen, which ultimately derives from Nietzsche, does not necessarily imply the disciplinary view of man that Gehlen draws from it. Gehlen opens his major work Mensch, seine Natur und seine Stellung in der Welt (1950) with the reference to Niezsche's view of "man" as "the not yet determined animal"(das noch nicht festgestellt Tier). But the idea that human beings as not yet festgestellt, i.e. not yet deterministically assigned to a specific environment, does not necessarily call for a view of human beings as "beings that must be disciplined" (Zuchtwesen).

On the contrary, if one points to the fact that human beings are, at the same time, given to certain circumstances of existence but because they are always not yet festgestellt, i.e. they must re-elaborate the very conditions of their existence, then they appear as a Surplus-wesen rather than as a Mangelwesen. The idea of a Mangel immediately calls for a closure, and thus for discipline, but in this way it is only one aspect of the ambivalent relationship that human beings entertain with the conditions of their existence that comes to light.

The relationships between an always noch nicht festgestelltes Tier and the conditions of its existence are ambivalent: the "not yet determined animal" does not completely control these circumstances, since, to put it in Heiddegger's terms, it is "thrown into the world" (Heidegger 1927) but, at the same time, s/he does intervene over them in a way in which no other animals do. This is not the sign of a Mangel: it is rather that of abundance.

The working of myth is thus the working against an "absolutism of reality" understood in this way: whatever stage we are at, we have always already gone beyond this absolutism, because we have gone beyond pure chaos. ${ }^{110}$ A synonym for

\footnotetext{
${ }^{110}$ Castoriadis makes a similar point in his work on the imaginary constitution of society. Instead of the concept of "absolutism of reality" he uses that of "chaos": whatever stage of the institution of the society be, the work of its imaginary significations against the absolutism of the chaos has already started (Castoriadis 1975).
} 
"absolutism of reality" might thus be the concept of chaos (Angehrn 1996), even though what gets lost in this is the political register of the category of "absolutism of reality" and thus the possible political nature of the answers. ${ }^{111}$ Whatever concept one decides to employ, however it should be clear that the working against the "absolutism of reality" or "chaos" has always already started and that myth is thus the sign of its overcoming.

As Blumenberg observed, there is thus a functional analogy between myth, science and religions, inasfar as they all are a means for the creation of meaning. What differentiates, then, the working of and on myth from other forms of Sinngebung such as science or religion?

In the first place, myth, in contrast to science, does not technically aim at explaining (erklären). As Malinowski observed in his essay on Myth in Primitive Psychology, myths do not explain (or better they do not explain in the sense in which science does), although they still make everything clear. Myth, in other words, is not an explanation that is put forward to satisfy a contemplative curiosity over the world. Rather, it derives its crucial features from the fact that it has a specific social function. As we read in a passage describing the role played by myths among the "primitive" peoples:

"The myth in a primitive society, i.e. in its original living form, is not a mere tale told but a reality lived [...].These stories are not kept alive by vain curiosity, neither as tales that have been invented nor again as tales that are true. For the natives, on the contrary, they are the assertion of an original, greater and more important reality through which the present life, fate, and work of mankind are governed, and the knowledge of which provides men on the one hand with motives for ritual and moral acts, on the other with directions for their performance" (Malinowski 1926).

Whilst commenting this passage, C. Kerényi observed that Malinowski understood that the function of myth is not to provide a scientific or "pseudoscientific" explanation. However, according to Kerényi, he lacked the proper word to describe its function: he rejected "explanation" (Erklärung) but the sense in which myth can make

\footnotetext{
"II'This political register of Blumenberg's concept of myth facilitates the task of linking philosophical theories of myth with the social sciences' treatment of political myth. All the same, at this stage it should be clear that even if Blumenberg's theory had clear political connotations, it is not specifically aimed at an understanding of political myth.
} 
things "clear" (klar) remains obscure. The German language has however - Kerényi observed - the right word to describe this: it is begründen (Kerényi 1941: 6).

The root of the concept of begründen, which can perhaps at best be rendered with "to ground" or to "substantiate", is the term "Grund". Grund means indeed both the English abstract noun "reason" and the concrete noun "ground". Myths tell stories, they tell what the origins of things are, and, thus, at the same time, where they are going to. They provide a "ground" but they do so by answering the question "whence?" rather than "why". In this way they provide things with what in the German language correspond to a Grund.

According to Kerényi, the difference between myth and science can be elucidated very well in Greek. Myth does not indicate aitia. Or better, it provides aitiai only to the extent that, as taught by Aristotle (Met. 1013a), the aitiai are archai, i.e. beginnings or first principles. The happenings in a myth are not "causes" in the modern sense, i.e. in the sense of a necessary connection between events, but are rather grounds or primary states. And it is in this sense only that they can be said to lay "the foundation" of things (Kerényi, 1941:7). ${ }^{112}$

Myths are thus not only simple stories about the origins. There are, indeed, stories of the origins that are not myths. Together with Blumenberg, and perhaps against Kerényi, ${ }^{113}$ we must recognise that the reason why myths succeed in their begründen is that they generate significance (Bedeutsamkeit). A myth is not just a story, but is a story that works as Begründung because it "makes significance" of a certain experience. Whereas all narratives provide facts with a meaning by simply inserting them in a plot, a myth is a narrative that succeeded also in making significance of them.

Blumenberg defines the Bedeutsamkeit as a "defence from indifference", mainly understood as "indifference in space and time" (Blumenberg 1979, I, 3). Consequently, myth can be defined, as what makes things closer to us: whereas something can have a meaning, but I can still be completely indifferent to it, something that is significant is something that I fell "close" to. This has at least one major consequence: whereas science can be universal, significance is always particular. What is a myth under certain conditions and for certain subjects can be a simple story for others. Further:

\footnotetext{
"12 On myth as form of justification see also Frank 1982. In the context of his discussion of German idealism, Manfred Frank also observes that the typically mythical justification is "eine Begrïndung aus Zwecken" (Frank 1982:160).
} 
what is a myth for me "here" and "now" can in the future be declassed to the status of simple story. What, then, lies beyond this situatedness of significance?

As has been observed, Blumenberg derives the term Bedeutsamkeit from Dilthey. ${ }^{114}$ The concept thus recalls the context of the discussion about the difference between the Geistes- and Naturwissenschafien. Whereas positivist approaches, following the Humean tradition, claimed the unity of scientific method on the basis of the dogma of invariability of natural laws, Dilthey claimed the autonomy of the human sciences on the basis of their different object: the Geist, i.e. what is specifically human, as opposed to Natur.

However, the distinction between Geist and Natur seems to be very problematic in itself, in the sense that the Geist can be seen as natural and that the Natur on the other hand can be said to be spiritual. However, the connection of the term "Bedeutsamkeit" with the debate about the nature of the Geisteswissenschaften is very significant. If human beings are noch nicht festgestellte Tiere, i.e. not yet determined animals, they entertain a problematising relationship with the conditions of their existence. Whereas these latter, are "given" for most the other animals, in the twofold sense that a fish dies out of water and that, as far as we know, it does not raise questions about this fact, human beings question them: not only do they change, at least to a certain extent, the conditions of their own existence, but they also question these conditions. It is from all these questions that a need for significance derives and the working on myth stems.

This does not mean that myth is the only way to provide significance and thus to combat indifference. It only means that, to put it in Geertz's words, the human being is an animal suspended in webs of significance (Geertz 1973:5) and that myth is one of the way in which this animal has elaborated those webs and thus provided a "grounding" (Grund) to the conditions of his existence.

The plural is very important here. In the sentence "conditions of existence" the emphasis must be on the plurality of these conditions. Everything that is part of the experience of human beings is part of these conditions and can therefore be the object of this questioning. The point is crucial because not all myths aim at explaining the whole sense of being, i.e. the "condition of the existence of human beings" in the

\footnotetext{
${ }^{113}$ See in particular the passage where Kerényi states "it is no groundless generalization to say that mythology tells us of the origins or at least of what originally was (Kerényi 1941:7).

${ }^{114}$ On this point, see Jamme 1991: 116 ff. Jamme does not, however, draw any conclusions from this fact.
} 
singular. Some of them, but not all, do, and to assume that they all do would preclude the possibility to see the working of myth in its variety, richness and also banality.

On the one hand, thus, myth differs from science because instead of looking for the abstract relationships between causes and effects it aims at "grounding" the world in which human beings live - a task that science, limited as it is to answering the question of "how?" cannot perform. To put it in Wittgenstein's words, the problem of science is "how" the world exists, and not "why", and as a consequence he is right in saying that even when all possible scientific questions have been answered, the problems of life remain completely untouched (Wittgenstein 1921, 6.52).

On the other hand, though myth does not for this reason coincide with religion or mystic. Simplifying things, we can say that myth answers the question "Why?" raising the issue "Whence": as such it can limit itself to telling a story about some of the conditions of existence, without necessarily aspiring to answer the question of the sense of life in general. Bedeutsamkeit situates itself precisely between two extremes: meanings on the one hand (the Bedeutung- or Sinnfrage: "What is this?") and the sense of "the Being" on the other (the Seinsfrage: "What is the sense of being?"). Bedeutsamkeit is not (only) meaning, because there is meaning each time that there is language. But Bedeutsamkeit is not necessarily Seinsfrage either, because some myths do not aim at providing explanations of the "ultimate meaning".

Thus, it is not necessary to question the whole sense of life in order to enable the working of myth and on myth: everything, even the most banal event, can be the object of a mythical narrative - just as everything can acquire significance. In other words, there is no need for any shedding of blood in order to see a myth at work. The working on myth starts indeed before than raising the issue of the meaning of death. Therefore, if we agree with Cassirer and Malinowski in saying that religion, notwithstanding its variety of manifestations, has always been and always will be "a question of life and death" (Cassirer 1946, 4), then we also have to conclude that not only not all myths are religious myths (and that this must necessarily be so), but also that religion is a way an attempt to "bring myth to an end".

"Bringing myth to an end" is the expression used by Blumenberg to designate the attempt at a closure exercised by any attempted "final myth" (Blumenberg 1979, II, 7; $\mathrm{V}, 19)$. By advancing a whole interpretation of the sense of life and death, religious myths aspire to get rid of the need for significance. On the contrary, the working on 
myth is moved by a need of significance that is continually fostered by the changing of the circumstances in which we live. In particular, whereas religion, by answering the question of the meaning of life and death, also radically aims to resolve the problem of the incongruence between "good" and "luck", the working on myth is fostered precisely by the impossibility of providing a definitive solution to the problem of this incongruence.

This is a crucial point. The problem that Greek tragedy shared with Greek philosophy was the need to face problem of the "fragility of goodness" that emerges from the problematic relationship between "good action" and "luck" (Nussbaum 1986). It is from this problematic relationship that the pathos of myth emerges. Whereas religions, as Weber pointed out, aim at resolving this problem at its very roots, the working of myth stems from the variety of possible configurations of the relationship between "good" and "luck". And whereas philosophy mainly deals with this problem by rational argumentation, myth deals with it by telling stories.

If myth has to make significance of the changing circumstances of fortune, it has to be open to a process of retelling. Hence, what I have called the "plurality of myth", something that different authors - from Aristotle to Blumenberg - have always emphasised. Myth is pluralistic not only in the sense that its meaning is construed by the interplay between the narrators and receivers of myth, but also in the sense that what can provide significance, and thus be a myth for someone, may not be a myth for another person. Therefore there is also no definitive answer to the question of the concrete means by which significance can be created. There are many ways by which which significance, thus understood, can be generated and they cannot be limited to any single form or type of content.

The concept of significance thus escapes most of the dichotomies created by an "enlightened reason": "myth" versus "reason", "passions" versus "reason", "consciousness" versus "unconsciousness". The working on myth can take place through conscious working on it, but it can also be located at a completely unconscious level. Myths, as a consequence, can be learned by conscious learning, but can also be learned by unconscious exposure to them.

The exposure to certain mythical narratives can influence how we perceive ourselves and the conditions of our existence, and thus also our orientations within them. In this sense, myths are stories that always bring a "morals with them": they can 
be more or less dramatic, but nonetheless, by making significance of certain conditions of life they always display a certain pathos. This latter must not, however, be understood in purely passive terms. Myths can be the product and the producer of the most inflamed passions, but passions can also tum out to be simple "upheavals of thought" (Nussbaum 2001).

Myths do not operate in a vacuum. Blumenberg's concept of working on myth (Arbeit am Mythos) suggests precisely this: each variant of a myth, as well as each different mythologem, works over the ruins of pre-existing edifices. The pre-existing material is then directed towards to new exigencies and transformed in order to give significance to the new circumstances through a process that Blumenberg called "Umbesetzung", i.e. "re-occupations" (Blumenberg 1971). ${ }^{115}$ The ways in which this can happen are innumerable. Return of the identical, linear sequences, proximity in time, correspondence in places, circularity in space, and so on - they can all be ways of creating and reproducing significance.

Thus, for example, the power of the mythologem of Homer's Odyssey rested in the circularity of Ulysses' voyage. Left his Ithaca for the war of Troy, he has to overcome all sort of human and divine obstacles on his way back. Going through the different vicissitudes of fortune, his travelling delineates however a circular process. Indeed, it was assumed that this circularity would generate a cathartic effect in the reader.

But myths are recounted, and as far as they are told- received they are also possibly told again. The Ulysses that we find the Divina Commedia is a Ulysses who paid the high price of his return back to Ithaca to the God of the Christians: the fraudulent Ulysses who has suggested the stratagem of the horse to overcome the Trojans' resistance and violated the limit of the Hercules' columns imposed by God would never see his faithful Penelope again and would eventually die swallowed down by the sea (Inferno, XVIII). With this episode Dante aimed at showing the dangers hidden in an absolutisation of human hybris: the way to do so was to break the circularity of the Homeric Odyssey.

In a letter to Carlo Linati, Joyce writes that the intention of his Ulysses was to render the myth "sub specie temporis nostri" (Letters of James Joyce, 21 September 1920). The odyssey of the banality of the itinerary covered in one day in Dublin at the beginning of the twentieth century by Leopold Bloom seemed to recover the circularity

${ }^{115}$ On Blumenberg's concept of Umbesetzung see also Leghissa 2002:23. 
of Homer's Odissey, but in fact breaks it, whilst apparently recovering it. Leopold Bloom woul then go home, but, in a monologue by Molly Bloom, we know that Penelope is thinking about being unfaithful to her husband. The Arbeit am Mythos continued and the reassuring circularity of the old myth breaks up when seen sub specie temporis nostri.

Consequeltly, when Mircea Eliade, following Nietzsche, identified myth with the eternal return he was pointing to one of the possible means for the working of myth. To make recourse to the circularity of the eternal return is, indeed, a way of reproducing significance, but it is only one of the narrative plots whereby significance is produced and reproduced and it can therefore be identified with the myth tout court. According to Eliade, the main function of the myth as eternal return is to fix the exemplar model for every significant human deed, like rituals, in a way such as to provide an ahistorical and a-temporal model. According to Eliade, thus, it is to this model that we can make recourse each time we have to do something for which the empeiria does not provide a guide (Eliade 1954).

However, not all myths are the sites for a hierophany thus understood. Not all myths are based on the eternal return of the identical, and not all myths are sacred myths. For instance, the Roman foundation myth was a truly historical myth, in the sense that it referred to a peculiar and singular event in the profane world of history. There was some dispute as to the date: Cato placed the founding of the city in $755 \mathrm{BC}$ whereas Varro's more careful calculation made it $753 \mathrm{BC}$. But the point remains that the city was founded not in the sacred world of primordial time, which is destined to return, but in the profane world of everyday life. ${ }^{116}$

Identifying myth with the eternal return of the identical is again a consequence of treating myth as the product of a primitive or traditional mentality. Myths have thus been identified with magic and religious beliefs and practices and thus they have been associated and often conflated with rituals. The parallel myth-ritual has been pushed so far that, for instance, according to the so-called the ritualistic school myths are nothing but the spoken correlative of acted rites. ${ }^{117}$

The problem with this view is not only that it neglects the fact that, as has been observed, not all myths have a ritual origin or are associated with a significant corpus

\footnotetext{
${ }^{116}$ For this critique regarding Eliade see Tudor 1972: 62.

${ }^{117}$ We will come back later on to this point when discussing the relationships between political myth and rituals.
} 
of rituals (Tudor 1972:29). By conflating myth and ritual into a common category of mythical or primitive thinking, the danger is that the working of and on myth is completely overlooked. Myths are indeed the sign of a working on myth that is fostered by the need to make significance of constantly changing circumstances, and it must therefore be open to the possibility of retelling. Rituals, on the contrary, are literally what is "well done" or "done according to the rules" - from the Latin rite. Therefore, in order to be effective for the cohesion of a social group, myth and ritual must operate in opposite directions: rituals must be kept unchanged, myths must continually change or, when this is not possible, as in the case of closed myths, simply be dismissed.

Rituals represent, in fact, a stability and continuity that is acted out and re-enacted in a visible way. They imply a visible continuity. By dint of repetition they deny the passage of time, the nature of change, and the extent of indeterminacy in social relations (Moore 1975: 167). On the contrary, the working on myth in order to be effective, i.e. to produce myths and not simple narratives, must be also the work of significance and thus reflect the conditions that are given hic et nunc. Myths, in other words, are always situational and must therefore always be retold from the point of view of the present. This is, in the final analysis, what moves the whole Arbeit am Mythos.

The emphasis on the difference between myth and ritual is more the result of a phenomenological approach to myth than the application of functionalism. In particular, to adopt a functionalist approach at this stage would mean decide from the beginning the role of myth within politics. If one assumes with Malinowski, for instance, that myth supports and maintains the social state of affairs (Malinowski 1948), there would be no need to develop a philosophy of political myth. On the contrary, it is only after having established what a myth is that the issue of its relationship with politics can properly be dealt with.

The approach to myth sketched above can thus perhaps be understood as "interpretative". Indeed, even if it does not presuppose a functional relationship between myth and the social-historical, this approach moves from a theory of meaning that presupposes some kind of relationship between the two. Wittgenstein did not write the book in anthropology whose first words he had expressed in his Remarks on Frazer's Golden Bough. The interpretative anthropology proposed by Clifford Geertz can perhaps be considered as an attempt to write such a book (Geertz 1973, 1983, 
2000). Following Geertz's approach, we can say that myths - inasfar as they have a meaning - presuppose a context and therefore a semiotic system within which only they can make sense and significance, and which, in its turn, it contributes to creating.

When Geertz stated that human beings are "animals suspended in webs of significance" (Geertz 1973:5), he seems to have been pointing out that we do not only need meanings to oriente us in the world, but also significance to rendere the world less indifferent to us. The task of the next chapters is to investigate the consequence that this have when it comes to political life and political circumstances. 


\section{POLITICAL MYTH}

The process of modernisation has deeply transformed European societies and the relationship human beings have with one another, as well as with society as a whole. One could indeed assume that the affirmation of a rational orientation of action (Weber), a highly developed social differentiation (Durkheim, Parsons) and an increased secularisation (Löwith) have brought about such a condition where there is no more need for mythological narratives: in the modern epoch, it is the rational Copernican man, who, against any absolutism of the tradition, is the subject of the process of legitimation.

History has disavowed this self-presentation of modernity. Myth has always reoccurred in Western civilisation - and the more powerful the attack against it, the more disruptive the forms in which it has reappeared. Thus, whereas the eighteenth century Enlightenment, in its critique of myth did not deny the legitimacy of the need from which it stemmed, nineteenth century positivism, by denying as meaningless and mystical any enquiry that is not subsumable to the principle of verification, denied legitimacy to those very needs and favoured the return of myth without mediation, i.e. myth as it has been used by totalitarian regimes (Blumenberg 1979).

In fact, modernity has not diminished the need from which myth stems. Rather, it can be argued that it has enhanced this need. To put it in Weberian terms, the old peasant may well die full of life, having fulfilled the circle of biological life, but the Kulturmensch, who is inserted in a never-ending process which transcends him and about which he is able to understand only a very limited part (Weber 1919a), is destined to feel the need for significance even more. The process of disenchantment (Entzauberung) implies an increased intellectualisation, which, on the one hand, reflects the human awareness of being able to master the world, but on the other, given the high level of 
specialisation of knowledge, also means an increased distance from the possibility of understanding the conditions under which we live. To again use a Weberian example, while the savages know how the instruments they use in their everyday life work, the Kulturmenschen are surrounded by many objects and means that they depend on and whose mechanisms are completely unknown to them (Weber 1919a); hence possibly an increased distance from the world and, consequently, also an increased need for significance.

It comes as no surprise then if it is in the conditions of modernity that the role played by political myth becomes conspicuous. The complexity of modern societies and the acceleration that they involved by transcending the individuals' space of experience rendered more acute the need for a symbolic mediation of political experience. Complex and vast political phenomena transcending the individual's horizon of experience need to be imagined even more in order to be experienced. The concept of political myth points to the fact that this imaginary mediation can also take the form of a narrative that produces and coagulates significance, i.e. of a myth.

Myth however must not be understood as a regression into superstition. By criticising Bayle's approach, considered as paradigmatic of the Enlightenment's attitude towards myth, Chapter 7 argues that myth can play an important part in the critique of political reason. Accordingly, definitions of political myth in terms of regression (Cassirer) must be rejected (Chapter 8). This does not mean that political myths are necessarily means for critique or for progress. The following discussion of the classical theories of political myth, following Spinoza, rather concludes that political myths are neither good nor bad per se (Chapter 8 ).

Indeed, one should, in the first place, see in political myths the always changing working on a common narrative by which the members of a social group (or society) make significance of their experience and deeds (Chapter 9). In this sense they are an important component of modem political life, together with ideology and utopias, with which they sometimes overlap but from which, however, they must be kept distinguished (Chapter 9). 


\section{MYTH AND THE CRITIQUE OF POLITICAL REASON}

The aim of Bayle's Various Thoughts on the Occasion of a Comet (1682) was to undermine the influence of "superstition" in politics. To this end, by criticising the view of comets as presages of misfortune, he made his notorious claim that a decent society of atheists is possible: sound political life does not require and it might even be harmed by religious beliefs. The claim, revolutionary for the epoch, was advanced with all possible precautions and the book was first published anonymously.

The reason for his precautions, as we have seen, ${ }^{118}$ is that according to Bayle when events are reduced to their natural causes, they presage nothing anymore, and this deprives the people of an infinite number of "vain imaginings" on which they feasted, diviners of the most considerable part of their employment and statesmen of the possibility to take advantage of them (Bayle 1682,110). Statesmen have indeed in all times fomented these beliefs, because, as Bayle clearly states, "nothing is as powerful as superstition for keeping the populace in check. However unruly and inconstant they may be, if their minds are once struck by a vain image of religion, they will obey the diviners better than their chiefs" (Bayle 1682, 81).

The strategy adopted to undermine the role of superstition in politics is then twofold. On the one hand, Bayle argues that the beliefs in presages are ill-based, because if we analyse the phenomenon of comets with an "altogether pure reason" we see that there is nothing in them that links them with the advent of fortunes and

${ }^{118}$ On Bayle's Various Thoughts see also Chapter 3. In this chapter the focus is however explicitly on the political implications of the Enlightenment critique towards the role played by religious beliefs in politics. 
misfortunes: the link between their happening and any sort of calamity, is purely imaginary and stems from people's natural inclination to treat the slightest things as presages (Bayle 1682, 80,110). On the other hand, Bayle points to the danger of these beliefs for a sound political life. Here he advances the claim that a decent society of atheists is possible. In the part devoted to argue "that atheism is not a greater evil than idolatry" (Bayle 1982, 114-193), Bayle with his usual technique of camouflage gradually leads the reader to concluding that atheism is superior to both idolatry and biblical worship. Not only, he argues, do religious beliefs not constitute a brake on human behaviour, because human beings act according to their passions and not their opinions, so that "both [atheists and Christians] could never constitute a society if a brake stronger than that of religion, namely human laws, did not repress their perversity" (Bayle 1982, 129). But moreover, he suggests that religious beliefs might even undermine the possibility of a decent political life: both idolatry and biblical worship, in his view, have led human beings to committing such atrocities that they would never have committed, had they not been filled with religious zeal. By referring to the civil strife following the conversion of Henry IV, Bayle goes as far as to affirm: "Had the Court of France been atheistic, it would never have maintained such conduct" (Bayle 1682, 160).

Thus, not only Bayle argues that they are human laws, and thus coercion, that make society possible, because human beings are prey to their passions against whose force mind's general opinions and beliefs are completely impotent (Bayle 1682,138 ), but he also sketches all the atrocities that have been committed in the name of religion (Bayle 1682, 155, 197). Hence, Bayle can conclude that "a society of atheists would perform civil and moral actions as much as other societies do, provided that it punishes crimes severely and that it attaches honour and infamy to certain things" (Bayle1682, 172). Thus, neither the possibility of a society that is held together by human laws, nor that of morality is undermined by atheism. Indeed, according to Bayle, the idea of decency, upon which morality rests, does not depend on the belief in God (Bayle 1682, 181), but, on the contrary, is rooted in human nature (Bayle 1682, 172). An atheist, Bayle observed, is certainly capable of returning a deposit when he sees that his good faith will earn him the praise of a whole city and that his infidelity could one day subject him to reproach (Bayle 1682, 179). 
Bayle's criticism of superstition is paradigmatic of the Enlightenment's attitude towards the role of religious beliefs in politics: a decent political life does not require and might even be harmed by religious beliefs. Thus, some critics have recently suggested that we can also understand from Bayle how high the stakes in deriding the Enlightenment and its political achievements are: according to this view, in Bayle "we see something of what the world was before the rise of modern political philosophy", i.e. we see that, "absent the appeal to reason, the world teems with miracles and malevolent spirits." Therefore - so this view concludes - "those who celebrate the collapse of reason on the grounds that it will give rise to a more thorough toleration of all the "otherness", should be aware that this will in all likelihood give rise to religious superstitions" (Bartlett 2000).

Let us admit for the moment that modern political philosophy has actually succeeded in liberating politics from "miracles and malevolent spirits", even though, one could argue, we are surrounded by evidences pointing to the contrary. The problem still remains that, as Bayle himself points out in many places, this appeal to "an altogether pure reason" (Bayle 1982, 3) deprives human beings of an infinite number of "vain imaginings". These images, on the other hand, as Bayle recognises, stem from a natural inclination of human beings to form images and see in certain events signs for something else. Among the products of this natural inclination are also myths, i.e. those particular narratives that answer that which Blumenberg has called the human need for Bedeutsamkeit.

Now if the religious beliefs that Bayle criticises do live of this imaginary faculty, for it is not possible to believe in religious dogmas without imagining them, certainly not all the images that this faculty produces are religious. In particular, those images that, following Bayle, can appear as "vain" to an "altogether pure reason" are not necessarily religious images, which indeed are dangerous for political life. Otherwise stated, not all "vain imaginings" are necessarily "superstition", i.e. heteronymously given beliefs.

The problem then is that the Enlightenment, in its attempt to ground political life on the autonomy of the individuals and the critique of tradition, has unified under the heading of "superstition" all that which is not grounded on pure reason and, in so doing, it has assimilated all the "vain images" to religious superstition. But there is no such dichotomy as "pure reason" versus "religious 
superstition". There is much more in-between. Myth certainly escapes this dichotomy, since it cannot be reduced to "pure reason" - neither in the form of a strategic rationality nor in that of rationality in respect to values. On the other hand, this does not mean that they are superstitious beliefs. Indeed, there are myths that are religious myths, but not all myths are religious.

On the contrary, as we have seen, whereas religion, in whatever ways one tries to define it, "is always a matter of life and death" (Cassirer 1946, 4), a set of beliefs meant to solve the problem of the sense of life and death in general, a myth is not necessarily so. The need for Bedeutsamkeit from which myth stems is not merely need for meaning, but it is also not necessarily Seinsfrage, or a question over the ultimate sense of life and death. Thus whereas religion, by providing an answer to the ultimate questions tends towards a closure of meaning, i.e. to reinterpreting all that happens (e-venit) within its categories - thus this is the closure of a system in the mathematical sense - a myth is not necessarily so, precisely because it does not necessarily aim at closure. On the contrary, myths as narratives aimed at answering a need for Bedeutsamkeit, must be open to the possibility of changing in accordance with the changing circumstances and the new need for Bedeutsamkeit that they generate.

Thus, even if modern reason has undermined the role of religious beliefs as horizons of sense in the experience of the world in general, and of politics in particular, it has not necessarily undermined that of myth at the same time. In particular, if one can argue that modern political philosophy has detached politics from its transcendental anchorage in the great chain of being, this does not imply that it has also abstained from any possible recourse to mythical narratives. At the same time, as we shall show, it needed not do so.

Indeed, it seems as if the reason that is at work in modern political discourses can hardly be described as an altogether pure reason from this point of view. Even modern contractualism, which, it has been claimed, represents the apex of the struggle of political theory against myth, (Cassirer 1946:13), has also had recourse to mythical narratives. It would be easier to show the link between modern political reason and myth by taking other traditions of modern political thinking that have explicitly had recourse to a narrative dimension. It would most probably be easier to show the working of myth in Mandeville's Fables of the Bees or perhaps 
even Machiavelli's Discourses: in both cases there is some grounds to suspect that the narrative structure is used to construct a sphere of significance, i.e. that it leaves room for the working of and on myth. However, a much stronger argument would be to take precisely those traditions that have explicitly aimed at getting rid of myth and seeing whether they have actually succeeded in their intent or not.

Social contract theorists, in particular, are usually credited with the merit of having provided a purely rational foundation of political power. In contrast to mainstream medieval political theory, the necessity of a common power is not derived here from the sacred history, but from the will of individual human beings. In the mechanistic post-Galilean world, the existence of a polity is no longer a ring in the great chain of being, but simply a human artefact. The great revolution behind the idea of a "social contract" is that the existence of a political power can now only appear as justified on the basis of the will of single individual human beings. As Cassirer argued, by dissipating the mystery surrounding the origins of the polity and leading them back to the will of individuals, social contract theories have also got rid of myth (Cassirer 1946, 13). ${ }^{119}$

Hence, according to the self-presentation of an enlightened reason one would indeed expect to find no traces of myth in social contract theories, but only the working of a pure reason. Hobbes, for instance after having laid the foundations of the rights of the sovereign power and of the subjects in the commonwealth, claims to have derived them from the "Principles of Nature onely; such as Experience has found true, or Consent (concerning the use of words) has made so" (Hobbes 1651, III, cap. xxxii). It is only when moving on to handle the nature of a Christian commonwealth that Hobbes admits the need to recur to the supernatural revelations of the will of God, and then to the tales told by the prophets ${ }^{120}$ (Hobbes 1651, III, cap. xxxii). Thus, whereas in the first two parts of the Leviathan it is only the principles derived from experience or from the consent concerning the use of words that are described, in the third - and more substantial - part prophetical tales are also admitted.

\footnotetext{
119 As we will see, though, Cassirer's approach to myth is still trapped in the Enlightenment dichotomy of myth versus reason, whereas, on the contrary, one can argue that it is not because social contract theories have aimed at dissipating the mystery surrounding the origins of the polity that they have thereby got rid of myth: myth, as Blumenberg argues, is already an attempt at dissipating the mystery.

120 On the concept of prophets, see Spinoza's theory in the next chapter.
} 
Thus, when analysing the first two parts of the Leviathan we would indeed expect to see only our natural reason at work - where reason according to Hobbes is the faculty that "does nothing else but conceive a summe totall from Addition of parcels; or conceive a remainder from Subtraction of one summe from another: which (if it be done by Words) is conceiving of the consequences of the names of all the parts to the name of the whole; or from the names of the whole and one part, to the name of the other part" (Hobbes 1651, I, cap v). Nevertheless if we analyse the overall reasoning concerning the justification of sovereign power, we do not see such a pure reason at work.

In fact, the mechanism of political obligation, i.e. the necessity of standing in awe of sovereign power, is triggered by a great narrative: that of the exit from the state of nature. According to Hobbes, human beings are driven to institute a sovereign power in order to escape the state in which human beings are naturally in, which is a state of perpetual (potential) war, where homo homini lupus, and in which any single human being, being equally equipped by human nature, is equally exposed to the possibility of death (Hobbes $1651, \mathrm{I}$, xiii). Once the state of nature is depicted in such a way, the next step in the argument consists of showing how natural reason prescribes each man to exit from it (Hobbes 1651, I, xiv). Thus, whereas in this second moment it is only a pure reason that is at work, i.e. a Hobbesian reason that merely calculates the consequences of living in such a state and then prescribes exit from it, on the other hand it can be argued that the reason that creates the narrative of the state of nature is not a pure reason.

The recourse to a mythical narrative within philosophical theory comes however as no particular surprise. Recent theories, in particular, have emphasised that philosophers in their "rational" theorising have also had recourse to images, metaphors, narratives and even myths. Among the mythological narratives that have played a major role among philosophers there has been the idea of a "state of nature" (Midgley 2003). A detailed analysis of the use of the narrative of the state of nature in John Rawls has for instance suggested that this narrative, which is indeed presented as a device of "pure reason", is in fact not so "pure": rather it has been claimed that the narrative of the state of nature works to a great extent like myth (La 
Caze 2002,4$)^{121}$. In particular, it has been suggested that Rawls's narrative of the "veil of ignorance" and the "original position" work as a myth in as far as they disguise fundamental social inequalities and thus make it difficult to theorise group oppression (La Caze 2002: 94ff).

Whether Rawls's original position works as myth or not, the recognition of the possibility that philosophers make recourse to myth no longer comes as a surprise. To put it bluntly, only reason caught in the dialectic of Enlightenment can assume a dichotomy of myth versus reason so that when reason is at work there is no space for myth. Rather, there is in principle no reason to assume that, within a philosophical system which presents itself as based on rational inferences, there can be no space for myth.

Hobbes, together with most other social contract theorists, explicitly claims that his state of nature must be understood as a rational device, an "Inference made from the theory of passions" (Hobbes 1651 , I, xiii). All the same, when we move on to analyse the way in which the image of the state of nature works, it seems that not only does such a rational device take the form of narrative, but that this narratives also comes from and, at the same time, generates a series of figures, images and symbols answering to what we have called a need for significance. In other words, it seems as if this narrative works as a myth.

In order to see whether the state of nature is a myth or not, we must not look at its content and ask whether it is real or unreal. Thus, for instance, even if Hobbes had conceived the state of nature as an historical event, as Locke was to do, it could still be argued that it worked as a myth. ${ }^{122}$ Indeed, it is at the Arbeit am Mythos of the state of nature that we must look. This, in the first place, implies that even if for a contemporary reader it is only the aspect of the rational device of the state of nature that comes to light, it was not necessarily so for Hobbes's contemporaries. Significance, as we have seen, is always positional. Thus, even if one now might

\footnotetext{
${ }^{121} \mathrm{La}$ Caze focuses her attention precisely on the "analytic imaginary", i.e. on the repertoire of images, metaphors and myths recurring in the writings of contemporary analytic philosophers (La Caze 2002) ${ }_{122}$ As we will see, most modern political myths stem from historical narratives, i.e. from narratives that present themselves as historical events. Examples are the myth of the French Revolution and the myth of the Italian Resistenza.
} 
consider the state of nature as a "rational device" or even as a "mere story"123, it was certainly not so for Hobbes's contemporaries and first readers.

In the passage quoted above, Hobbes continues by saying that for those who do not trust his view of the state of nature because it might appear strange to them that "nature should dissociate, and render men apt to invade, and destroy one another, it can be shown that experience itself confirms this inference" (Hobbes 1651,1 , xiii). Thus, when confronted with the possible objection that there was never a time or condition of war such as that he is depicting, Hobbes replies that even if there has never been such a condition, all over the world, "there are many places where they live so now. For the savage people in many places of America, except the government of small Families, the concord whereof dependeth on natural lust, have no government at all, and live at this day in that brutish manner, as I said before" (Hobbes 1651, I, xiii).

Why did Hobbes need to make reference to the "savages of America" if he only wanted to build a rational device? Hobbes aimed at building a model for political obligation, and any model, by definition, cannot fully encompass the dimension of time. Thus, in the first place, one could argue that Hobbes's reference to the space and time of America is the necessary price paid by his model of temporality: the reference to the savages of America would then work as a means for leaving "time and space" out of the model. ${ }^{124}$

Hobbes does not only refer to the peoples of America. He qualifies them with precise terms. In the first place they are said to be "savages". The "savages", on the other hand, are described only in terms of what they are not - or rather of what they have not.: "in such condition, there is no place for Industry; [..]; no Culture of the Earth, no Navigation, nor use of commodities that may be imported by Sea; no commodious Building; no Instruments of moving, and removing such things as require much force; no Knowledge of the face of the Earth; no account of Time; no Arts; no Letters, no Society; and which is worst of all, continuall feare, and danger of

\footnotetext{
${ }^{123}$ Doubts might however be raised over the fact that the state of nature does not constitute a myth any longer. According to a report written by a Palestinian research centre in Ramallah for the World Bank, "the role of NGOs in Building Palestinian Civil Society" is to promote a "transition from a state of nature to a civil society" (Bisan Centre for Research and Development 2001: 5).

${ }^{124}$ According to Tudor, this is the function played by political myths: "political myths supply the theoretical argument with a concrete reference and a temporal perspective it would otherwise lack; and the theoretical argument endows the myth with academic respectability and a certain timelessly abstract significance" (Tudor 1972: 127). On this point see also Chapter 9, 10 and 12
} 
violent death; And the life of man, solitary, poore, nasty, brutish, and short" (Hobbes 1651, I, xiii).

The construction of the image of the savage through a series of negations was almost a common topos of the time. Not only was this common place in the huge literature circulating by that time - mostly made up of travel reports, novels and philosophical treatises -, but in the second half of the seventeenth century the stereotype of the savage became fixed into a definition that was repeated in all dictionaries. For instance, in the dictionary of the French Académie published in Paris in 1694 we read: "Sauvage, se dit de certain peuples qui vivent ordinairement sans religion, sans lois, sans habitation fixe et plutôt en bestes qu'en hommes". 125

The origins of the topos of the homines sylvestri go back to the large amount of reports from the exploration of the "New World" that started circulating at the beginning of the sixteenth century and, by Hobbes's time, was already a widespread literary genus. In particular, it is to the natives of North America that the topos is referred since the inhabitants of regions such as Central America and Peru, who did not live naked and had constructed stone buildings, were considered to be more civilised populations. The natives of North America, on the contrary, continually at war with each other, appeared to be the real "savages", the bottom of the civilisational scale.

As S. Landucci points out, around the figure of the savage is coagulated the results of the first experience of a radical diversity; the shock of their discovery was so deep that some authors of that time saw in it the source of all sorts of speculations in moral and political philosophy (Landucci 1972: 20). In whatever way the savages' lives weres evaluated, positive or negative, it still remains that the characterisation was made in terms of their "difference", so that Rousseau's statement "pour étudier l'homme il faut apprendre à porter sa vüe au loin, il faut d'abord observer les differences" can be used retrospectively to describe the fundamental attitude towards the huge amounts of new knowledge that could be drawn from the travellers' reports.

Hobbes's recourse to the narrative of the "state of nature" cannot be interpreted without referring to the sphere of significance surrounding the figure of the savages. Both when it is seen as the first expression of the discontent of civilised

${ }^{125}$ For what follows, see Landucci's I filosofi e I selvaggi, a systematic reconstruction of the role played by the figures of the savages in philosophers writing between 1580 and 1780 (Landucci 1972). More recently, see also Pagden 2000. 
Europeans (Freud 1929) or as the complex of the superiority of the European colonisers (Gliozzi 1977), the image of the savage is recognised as a very powerful reservoir of significance. ${ }^{126}$ The discovery of America was indeed an enormous shock that needed to be digested by Europeans and the figure of the "savage" coagulated the emotional and rational replies of the European to this challenge.

Not by chance thus Hobbes's passage, making a long list of the artes that locates human beings "supra conditionem caeterorum animalium" and the "gentes Europaeae" above the savage, is almost a topos in Hobbes's writings. ${ }^{127}$ In Hobbes's text, this figure refers to a very powerful image circulating in the literature of the time. Thus, despite the fact that some authors have contested the importance of the figure of the savage in Hobbes's theory by saying that his men in the state of nature are not primitive men, ${ }^{128}$ the savage does play a crucial role for Hobbes, who continuously exhibits him, from the Elements to the De Cive and the Leviathan, as a factual exemplum of his state of nature. On the other hand, what is of most importance in reconstructing the Arbeit am Mythos is that this figure played a fundamental role for Hobbes's audience, for whom the reference to the state of nature was not only "a purely rational device", but mobilised powerful resources of significance.

Thus, even if an analysis of Hobbes's use of this figure would indeed require a close reconstruction of Hobbes's sources, what interests us here is to analyse the role the figure of the savage plays in his politico-philosophical system and the way in which this was received. Indeed, the fact that all social contract theorists make reference to the figure of the savage in the same way, also suggests that this figure plays a rather crucial philosophical and systematic role. Notwithstanding the obvious difference in the sources available to authors as different as Hobbes, Rousseau and Kant, there are striking similarities in the role that this figure plays in their systems.

In first place, when they referred to the savages they were all thinking of a well determined referent. The "savages" were "the savages of America": the fact that

\footnotetext{
${ }^{126}$ By recovering Le Goff's concept of 'Oneiric Horizon' (Le Goff 1980). Padgen points out that the different variants of the figure of the savage must be read as attempts to reposition the 'Oneiric Horizon' in different spaces and times: the dream expanded here to a vision of a world where a different kind of life was lived, where taboos were eliminated or exchanged for others (Padgen 2000: xviii).

${ }^{127}$ See for instance De Corpore, I.i.7; De Cive beyond, of course, the English and the Latin Leviathan.
} 
a state of nature of humanity existed was accompanied, for them and for their readers, by a precise figurative image, an image that stems from the first experience of a "radical otherness". On the other hand, what confers to this image its specific significance is the narrative that lies beyond the idea of savages: as we have seen, the savages are what the Europeans are not, or better, what they no longer are because they have exited the state of nature. Thus, the significance of the figure of the savage cannot be understood without referring to the narrative of the exit from the state of nature, i.e. without referring to the typical way in which mythical nartatives coagulate and reproduce significance.

The narrative dimension of the state of nature can however take different forms. Whereas for authors such as Rousseau, this condition was completely lost, for Hobbes and his contemporaries the state of nature was also a condition into which human beings could always fall again, if they did not stand in awe of a common power. In particular, the continual state of inter-tribal wars that struck all the travellers because it appeared reasonless - now we know that they were wars for the division of hunting territories - appeared to Hobbes and his contemporaries to be the features of a civil war, for Hobbes the worst of evils and whose memory was not a distant one. Hence, the overall characterisation of the savages' natural condition in a completely negative way: the state of nature is depicted as a "brutish manner of living" because it lacks - or it appears to lack - all that which Hobbes held as worthy and appraisable in the world in which he lived, and also what he perceived as being in danger in the religious civil wars: peace, in the first place, and consequently, industry, culture, navigation, comfortable buildings, instruments of moving, knowledge and an account of time (Hobbes 1651, I, xiii).

Thus, the state of nature has a rather crucial function in grounding (begrïnden) the present state of things for the "civilised Europeans". This grounding is not only achievable by a pure reason calculating abstract consequences, but also by telling a story and inserting the advent of civil society into a narrative. This is the typical way in which myth produces significance. Thus, a great part of the reasoning rests on a sequence of events (state of nature, exit from this state and institution of a sovereign power through a social contract) that coagulates and recreates significance.

${ }^{128}$ See in particular the classical interpretation by Warrender and Macpherson (Wartender 1957: 143; Macpherson 1964:18-29) 
Notwithstanding all the possible variants of this narrative, the means through which significance is created in social contract theories is the opposition chaos/cosmos, which is perhaps one of the most typical narrative schemes for making significance of the vicissitudes of fortune. The exit from the state of nature can be conceived either as a single moment or it can double as a pactum societatis followed by a pactum subjectionis, but in both cases the narrative is constructed around the two polarities: chaos and cosmos.

Rousseau, though, modified this scheme substantially. By reconstructing the changes through which the state of nature as myth went, is perhaps the best way to show the role that myth can play within the critique. Not by chance thus, have many critics seen in him the first big rupture within modernity. Rousseau began his $D u$ contrat social with a description of the passage from the "Etat de nature" to the "état civil" and ends by vindicating the need for a "religion civile". By taking distance both from Bayle, by saying that no polity has ever been founded without religion as a basis for its construction and from those who claimed that Christendom is the best anchorage for a polity, Rousseau vindicated the need for "une profession de foi purement civile dont il appartient au Souverain de fixer les articles, non pas précisément comme dogmes de Religion, mais comme sentiments de sociabilité, sans lesquelles il est impossible d'être bon Citoyen ni sujet fidèle" (Rousseau 1762: IV, viii).

Thus, despite the fact that in the following paragraph, Rousseau seems to contradict this statement by moving on to delineate positive and negative dogmas of this religion - dogmas typical of the eighteenth century deism - what is interesting to us is that, in contrast to Bayle's enlightened reasoning, which deprives human beings of all sort of "vain imaginings", Rousseau recognises the need to articulate loyalty towards the polity in an imaginative dimension. All the same, Rousseau's characterisation of civil religion remains ambiguous, not only because he spells out the dogmas of this religion in a patently religious sense (so that, together with the holiness of the social contract, among those dogmas appears the existence of God, life after death, happiness of the righteous, and punishment of the impious), but also because he insists on the possibility of banishing those who do not believe in them. All this goes in the direction of assimilating myth to religion, whereas, as we have seen, not all myths are religious. 
Rousseau, though, went even further in questioning Enlightenment. He undermines the whole self-narrative of political modernity by adding a third dimension to the mythologem of the state of nature/civil society, a different starting point. Despite the fact that it is very difficult to reconstruct the different phases of the exit from the state of nature in his Discours sur l'origine et les Fondements de l'inégalité parmi les hommes, it appears legitimate to state that, in his thinking, the narrative scheme of the state of nature is a threefold one: no longer, like in Hobbes, a linear passage from chaos to cosmos, but a passage from the cosmos of the primeval state of nature to the chaos following the exit from that state and finally to the possible reconstitution of a cosmos through the institution of a social contract.

Thus, human beings, according to Rousseau, are not naturally driven to a war of everybody against everybody: philosophers, such as Hobbes, who depicted them in such a way, thought they were describing savages but, in fact, they were depicting civilised human beings (Rousseau 1754, Discours, v). What authors such as Hobbes depicted are human beings who are in dependence of each other, because they have many needs and are therefore prey to violent passions. But these cannot be the savages, who according to Rousseau, have such limited needs and moderate passions that they are completely independent from each other, and therefore genuinely free. Rousseau's savages live a solitary life, they have very basic needs that they can easily satisfy with the help of nature, and they have thus calm passions and very sporadic contact with each other (Rousseau 1754, I). Far from being a state of war of everybody against everybody, it is a condition of peace from which human beings can exit only as a consequence of an unhappy series of miracles. ${ }^{129}$ Among those miracles: the institution of private property, following the rise of agriculture and metallurgy (Rousseau 1754, II).

Even if Rousseau sharply questions the narrative of modernity as a linear progress from chaos to order, it can be sustained that, by neglecting the mythical nature of this narrative, he still has one foot in the presuppositions of Enlightenment. Indeed, at different points Rousseau claims that the state of nature must not be understood as a narrative of the historical origins, but rather as a rational device. In

\footnotetext{
${ }^{129}$ In the first part of the second Discours Rousseau states talk of the exit from the state of nature as a "Concours singuliers et fortuits de circonstances" and "qui pouvaient fort bien ne jamais arriver" (Rousseau 1754, I, xi). At the beginning, he had talked of an "enchainement des prodiges" (Rousseau 1754, Discours, 4).
} 
the second discourse, the Discours sur l'origine et les Fondaments de l'inegalite parmi les hommes, he clearly states that "we must not take the research that we can undertake on this topic as historical truth, but only as hypothetical and conditional reasonings, better suited to clarifying the nature of things than to showing their genuine origins, such as those that our physicists make every day on the formation of the world" (Rousseau 1754: Discours vi,78; translation mine). Now if the reference to "only hypothetical and conditional reasoning" leaves space for interpreting this construction as a myth, with this reference to the "discourses of the physicians" he seems to deny the mythical side of the idea of a state of nature.

All the same, it can be argued that what he does in the second Discours is precisely to retell a myth. By adding a new moment to the narrative scheme chaos/cosmos, Rousseau gives a new interpretation to the myth of the state of nature and thus a new grounding (begründen) to the "société civile" that emerges with the exit from this state. By doing do, Rousseau is not only, as he claims, raising in his readers a chain of hypothetical and rational reasoning, but also a whole series of images, figures and narratives under which the discontent of civilisation finds expression. Thus it is not by chance that the referent changes too: instead of referring to the savages of North America, Rousseau continuously refers to the Caribbean, that he presents as, "Celui de tous le peoples existants qui jusqu'ici s'est écarté le moins de l'état de nature" (Rousseau 1754: I): he refers continuously to this exemplum, now to say that despite their nakedness they do not fear other animals because they have developed all their faculties so that it never happened to them to be eaten by ferocious beasts, that they live in perfect calm and that their passions are so calm that, despite the hot climate in which they live, they are less subject to violent passions and jealousy and that, as a consequence of their very limited basic needs, they have not developed reason, so that they sell their cotton bed in the morning and come back and cry for having it back in the evening because they could not even foresee that they may need it again the following night (Rousseau 1754, I).

By referring to the savages reinterpreted in this way, Rousseau could add a third moment to the scheme chaos/cosmos and thus fundamentally re-interpret the self-narrative of modernity. Modernity does not represent a linear progress from chaos to order but, in the first place, the exit from a state of freedom and peace for entering one of dependence and disorder. Once this has happened, the only way to 
recover the same freedom that human beings were enjoying in the state of nature at a different level is by means of political freedom: through a social contract whereby each human being gives himself to everybody and then to nobody, because it ceases in this way to depend on single individual human beings in order to subject himself only to the general will, human beings can recover the freedom they have lost by leaving the primeval state of nature on a different level (Rousseau 1762: I, vi). ${ }^{130}$

Therefore, Rousseau can conclude that with the exit from the state of nature and the constitution of the political body, human beings loose their natural freedom and then their right to whatever they can reach, but thereby acquire civil freedom, that is a moral freedom, because it is the only freedom that renders human beings masters of themselves (Rousseau 1762: I, vi). The passage is crucial and deserves to be quoted entirely:

“On pourrait sur ce qui précède ajouter à acquis de l'état civil la liberté morale, qui seule rend l'homme vraiment maître de lui ; car l'impulsion du seul appétit est esclavage, et l'obéissance à la loi qu'on s'est prescrite est liberté (Rousseau 1762: I, viii).

Civil freedom seems here to be real freedom because freedom is literally obedience to a law that human beings have given to themselves. Thus, according to Rousseau, only through subjection to the law as expression of the general will to which each member of the political body contributes, can human beings properly speaking be autonomous, i.e. free. On the other hand, the subjection to impulses is said to be serfdom, because it is assumed that, in following their inclinations, human beings are not free.

Apart from the problems connected with this identification of autonomy with law and the exclusion of impulses from autonomy, since it is not said, unless one assumes a dualistic view of the subject, that impulses are necessarily heteronymous, what is interesting to note here is the tension that this view creates within Rousseau's thinking. We have seen that Rousseau starts his $D u$ Contrat Social with the exit from the state of nature and ends with the claim of the need for a civic religion whose positive dogmas he does not hesitate to spell out. But how can freedom, i.e. the autonomy of a subject, be guaranteed if $s /$ he who does not believe in

\footnotetext{
${ }^{130}$ By primeval state of nature, I mean the condition in which human beings are at the very beginning and that is described in the first part of the second Discourse, in order to distinguish it from the condition in which they find themselves after the introduction of private property and that is described in the second part of the Discourse: the error made by Hobbes and others who followed him is to take this condition, that is already a degenerated one, as the original state of nature (Rousseau 1754, II).
} 
those dogmas of faith can be banished from the polity? Is it not case a dogma of faith the opposite of an autonomously chosen law?

The alternative, however, is not necessarily, as we have already suggested, between a heteronymously given religious faith or the autonomously chosen law. The fact that Rousseau cannot find a better name for his civil religion is revealing of the fact that even if he perceives the limits of an enlightened approach such as that of Bayle, he still remains trapped within the alternative "law and thus reason" versus "religion".

The alternative between the autonomy of a general law and the heteronomy (and thus the serfdom), which Rousseau formulated at the political level, was transposed by Kant into the moral dimension. As is well known, Rousseau deeply influenced Kant's moral and political thinking. ${ }^{131}$ In particular, Kant followed Rousseau in interpreting freedom as autonomy, i.e. as giving the law to oneself. In the Perpetual Peace, for instance, after criticising the view of political freedom as arbitrium, i.e. as a warrant to do whatever one wishes unless this means doing injustice to others as an "empty tautology", he states that "external and rightful freedom should rather be defined as a warrant to obey no external laws except those to which I have been able to give my own consent" (Kant 1795, II, i: 99).

There is a clear similarity between this political freedom, conceived as autonomy and the moral freedom that Kant, in a similar way, defines as to subject oneself to the universal moral law. In fact, whereas at the speculative level Kant conceived of freedom as the faculty of starting a new series of causes, and thus as freedom of choice independently from the mechanism of natural causality (and for this reason he sometimes called freedom thus understood as causality by freedom), ${ }^{132}$ he subsequently identified this freedom with the subjection to moral law, and thus with the independence from impulses. Thus, whereas the problem of the Critique of Pure Reason was to show that reason can be pure, i.e. justify the possibility of knowledge on an a priori basis, the problem of the Critique of Practical Reason is to show that pure reason can be practical, i.e. that reason can affect the will directly.

\footnotetext{
${ }^{131}$ As many commentators have shown, Kant's political thinking is dependent on his moral thinking, because it depends on the categorical imperative. On this point, see Kersting 1992 and Habermas 1996.

${ }^{132}$ On this point, see particularly Kant's Critique of Pure Reason, the discussion of the three antinomies of reason in Kant 1787, Division Two, Transcendental Dialectic, Book II, Chapter II.
} 
And, as is well known, this is possible, according to Kant, only by recurring to the idea of moral law (Kant 1788).

Thus, it is in Kant that the Enlightenment's identification of autonomy with the autonomy of a pure reason that follows a universal law reaches its apex. On the other hand, it can be argued that not even his political theory, a view that posits the issue of autonomy as the basic principle of any rightful state, ${ }^{133}$ is completely "pure" from mythical elements. Kant did not write a "Critique of political reason". 134 Perhaps had he done so, he would have had to admit that his own political reason is not pure. He got close to affirming this when, in the preface to the Metaphysics of Morals, he wrote that a system of right is not possible because, being right a concept oriented towards practice, such a system would have to incorporate all the varieties and contingencies of experience within itself. Thus, in this domain we can only expect an "approximation to a system" (Kant 1797: Preface).

On the other hand, though, he assumed that the foundations of the system were already put in place by the Critique of Practical Reason. Indeed, the concept of right, defined as "the sum total of those conditions within which the will of one person can be reconciled with the will of another in accordance with a universal law of freedom" (Kant 1797: Introduction, B) is derived via progressive qualifications from the concept of obligation, or categorical imperative that, in turn, is elaborated in the Critique of Practical Reason. Kant presents his conception of right as derived from a priori principles of reason as they were first elaborated in the Critique of Practical Reason. In his view, an autonomous reason is a reason that takes its principles from itself. There are no other ways to autonomy.

But in fact, if we move on to analyse the way in which the necessity of the institution of a lawful condition is established, we do not see "pure reason" at work. Kant, like the other natural law theorists, recurs to the category of the social contract and the correlated pendant of the state of nature. Hence in Kant's political writings too there is a narrative of the human beings' exit from the state of nature and the creation of a politically lawful condition. And it can also be shown that this narrative works as a myth.

\footnotetext{
${ }^{133}$ See, in particular, his definition of the concept of right in the Metaphysics of Morals as derived from that of freedom (Kant 1797, Introduction).

${ }^{134}$ Kant considered Critique of Practical Reason, where he develops the concept of obligation, the critique that should precede the system delineated in the Metaphysics of Morals.
} 
Kant insists, even more than Hobbes and Rousseau, on neglecting the mythical side of his state of nature. He explicitly states that the state of nature must not be understood as an historical fact, since a fact drawn from experience could never, in his view, generate a right: the social contract is said to be an "an a priori idea of reason" (Kant 1797, I, I, §.43; Kant 1793, II, corollary). Thus, in the Metaphysics of Morals he affirms that

"It is not experience or any kind of factual knowledge that makes public legal coercion necessary. On the contrary, even if we imagine men to be as benevolent and law abiding as we please, the $a$ priori rational idea of a non-lawful state will still tell us that before a public and legal state is established, individual men, peoples and states can never be secure against act of violence from one another, since each will have his own right to do whatever seems right and good to him, independently of the opinion of others" (Kant 1797, I, § 44).

But how could reason state that each human being has her own right to do whatever seems right and good to her? What tells us that this is not pure reason, but a reason that recurs to the narrative of the state of nature: Kant does so with an explicit awareness that what this narrative evokes in his audience is not a "pure" chain of rational reasoning.

As is well known, Kant depicts this condition, not as a Hobbesian condition of war of all against all, but rather as a condition in which rights are only provisory (Kant 1797, I, §9, 44). But this remains an unlawful condition because right cannot be secured and human beings must therefore leave this condition: even if there can be society in such a natural state, Kant asserts that there cannot be any "civil society", that is a society that can guarantee the mine and thine through public laws (Kant 1797: Division). The term civil is here counterpoised to the condition of the state of nature that is the condition in which the savages live. Thus, in Kant too there is not only the narrative scheme of the passage from a natural condition to a civil society, but also the reference to the contraposition of "civilised" versus "savages" that we have seen playing a fundamental role in Hobbes and Rousseau. And for Kant's contemporary readers, the state of nature not only evoked rational reasoning, but also a whole reservoir of significance that grounds - in the sense of begrïnden the identity of the "civilised Europeans". 
In the Perpetual Peace, Kant describes the condition of the savages as that of a "lawless freedom", or "freedom of folly", as counterpoised to the "freedom of reason", for "they [the savages] would prefer rather to engage in incessant strife than submit to a legal constraint which they might impose upon themselves" (Kant 1795, II). Kant is well aware of the power that the figure of the savage evoked and has no doubt that his reader would have a similar reaction to them: "we all regard [savages' behaviour] as barbarism, coarseness, and brutish debasement of humanity" (Kant 1795, II). It is by evoking the passionate contempt of his reader for the "savages" that Kant hoped to persuade his audience of the necessity of a social contract between states.

Thus, even Kant, the advocate of the autonomy of pure reason, when elaborating his system of morals recurs to the working on the myth of the state of nature. All the same by identifying the critique with the pureness of reason and autonomy with the law, he seems to deny any legitimacy to myth as part of the critique. However, it can be argued that, it is the very identification of autonomy with pure reason that is fundamentally problematic.

In the first place, as we have seen not all myths, and even less all the "vain imaginings", are religious myths. Quite on the contrary, what characterises myth is precisely its plurality, i.e. the plurality that stems from the Arbeit am Mythos, from the fact that having to ground a world subject to change, myth has to be open to a process of continual re-telling. In this working of myth, which questions its own products, one can see a possible means for critique. The previous analysis of the way in which the mythologem of the state of nature changed and worked as a means for critique also is an example of the possibility to combine myth and the quest for autonomy.

Myth thus conceived does not necessarily lead to heteronomy. If heteronomy must literally be understood as subjugation to the law of another - be it the law of God or of an unquestionable tradition, then myth, because of its plurality, i.e. the fact that it expresses itself through variants does not necessarily mean heteronomy. Certainly there are myths, such as the religious myths, that because they aim at providing an answer to the whole sense of life and death, tend to leave no space for any alternative narratives. The religious myth of the God and lawgiver of monotheism is, as we have, seen paradigmatic from thi spoint of view. 
On the other hand, autonomy must not be identified with following the moral law given by reason. Kant arrives at this view of autonomy through the series of corresponding dichotomies that recurs throughout the Critique of Practical Reason: particular maxims for acting versus universal law, material principle versus formal principle of action, inclinations versus reason, pleasure versus duty, heteronomy versus autonomy. Thus in the heteronomy, Kant encompasses not only religious morals, but also, for instance, all the moralities of pleasure. According to him, he who follows his own inclinations acts in a heteronymous way, whereas only by subjecting himself to the categorical imperative of the law can he be autonomous. The problem here is the identification of inclinations with something that is heteronymous. In what sense, we may ask, are the inclinations the discourse of an "other" as much as the words prescribed by an omnipotent God can be said to be the discourse of the other?

We cannot here enter the details of a discussion of the Kant's view of autonomy and the shortcomings of the dualistic view of human beings that it presupposes. Suffice is to point to the limited character of such a view. The possibility of autonomy does not necessarily mean pureness of reason. Autonomy literally means to give the law to oneself, i.e. self-rule. The mistake of the Enlightenment appears then to have identified all that which is not grounded on an altogether pure reason with heteronomy and superstition. However, going back to Bayle's words, it can be sustained that a "mythical" society of atheists is not only possible: it is also desirable. 


\section{CLASSICAL THEORIES OF POLITICAL MYTH}

If modern political theory has to a great extent neglected the role that myth plays in politics, there has been a moment in European history when this role became tragically conspicuous. The massive use made by totalitarianism of political symbols, myths, and the achievements thereby reached not only manifestly exhibited the power of myth, but also posed a major intellectual problem for those intellectuals who had believed in the Enlightenment's promise of a liberation of politics from myth.

In 1946, the first book in Western political philosophy that, from the very title, promised to deal with the role that myth plays in the typically modern form of politics was published: it was Cassirer's posthumous The Myth of the State. The man Emst Cassirer, German of Jewish origin, who had to leave his homeland just after the advent of Nazism could not but perceive the morally tragic challenge posed by what appears to him to be the "appearance of a new power: the power of mythical thought" (Cassirer 1946: 3). On the other hand, the philosopher Cassirer, who had spent most of his intellectual life developing a theory of the symbolic forms in which myth was presented as a primitive form of consciousness, which had to be superseded by the advent of modern science, was also deemed to feel the intellectual challenge that this advent posed to him as to other theorists educated in the school of the Enlightenment. ${ }^{135}$

"In the last thirty years - so begin The Myth of the State - we have not only passed through a severe crisis of our political and social life but have also been confronted with quite new theoretical problems. [..] If we look at the present state of our cultural life we feel at once that

${ }^{135}$ Cassirer is, in first place, one of the major representatives of the so called neo-Kantian Marburg school, by which is usually meant a series of intellectual trends that between the end of the nineteenth century and the beginning of the twentieth drew inspiration from Kant's thinking against both idealism and positivism. Beyond his major work on The Philosophy of Symbolic Forms (1925), Cassirer is also author of a monograph on Kant's life and theory (1918) and of an essay on the Philosophy of Enlightenment (1932). 
there is a deep chasm between two different fields. When it comes to political action man seems to follow rules quite different from those recognised in all his mere theoretical activities. [..] Scientific knowledge and technical mastery of nature daily win new and unprecedented victories. But in man's practical and social life the defeat of rational thought seems to be complete and irrevocable. In this domain modem man is supposed to forget everything he has learned in the development of his intellectual life. He is admonished to go back to the first rudimentary stages of human culture" (Cassirer 1946: 3-4).

In the following pages, the problem is formulated more explicitly: if modern societies are characterised by their rational organisation and it is precisely on this basis that they are distinguished from traditional ones, how can the success of Nazism's appeal to myth be explained? The Myth of the State that, from its very title, had promised to be an analysis of the role that myth plays in the state is in fact the reconstruction of the Western attempt to get rid of myth. The text starts with a section where myth is defined as the form of life that characterises traditional societies and then moves on to analysing "the struggle against myth in the history of political philosophy", a section that occupies two thirds of the work. The "myth of the state" appears only at the end of the text, in a section which significantly recalls in its title Rosenberg's "The Myth of the Twentieth Century", one of the main ideological texts of Nazism.

Cassirer's The Myth of the State, thus, consists mainly of a huge synthesis of the history of political thought, starting with the first attempt of the West to exit from myth by the Greeks and moving on to medieval religious conceptions of the state, to Machiavelli and the social contract theories as a founding moment of a purely rational theory of the state, ${ }^{136}$ and finally ending with a relatively small section on the conceptions that prepared the advent of Nazism: Carlyle's theory of Hero worship and Gobineau's theory of races.

At the beginning of the last chapter, devoted to analysing the Technique of Modern Political Myth, Cassirer sustains that even after having reconstructed all the conceptual premises of the advent of Nazism, the success of its appeal to myth remains unexplainable (Cassirer 1946: 277). It may be recalled here that Alfred Rosenberg's "The Myth of the Twentieth Century" had an incredible editorial success selling more that 680,000 copies in only a few years (Rosenberg 1930: preface to the

${ }^{136}$ On the relationship between social contract theories and myth see previous chapter. 
1937 edition). The content of this book was a strange mixture of mysticism and "scientific" and "historical and archaeological" discoveries all devoted to demonstrating the existence of a superior race, the Aryan one. How could the success of this myth be explained?

It has been noted that, in Cassirer's view, myth is not just a simple way of thinking or speaking: myth, in his view, is a whole form of life (Lebensform). As such, Cassirer's myth encompasses all that which anthropologists have described using such different names as magic, religious practices and beliefs, worship and rituals (Krois 1979: 199). In this ensemble there is no space for a distinction between myth, religion and rituals: "myth" became the general name for all these beliefs and practices; and it is in them that Cassirer identifies the form of life (Lebensform) that in his view must hold together primitive societies.

If myth is what characterises traditional forms of political communities (what Cassirer calls "Gemeinschaften" and Schicksalsgemeinschaften) how could Rosenberg's appeal to the myth of the Aryan race have been so successful? In Cassirer's view, the difference between modern and traditional societies is precisely the difference between a Gemeinschaft held together by mythical beliefs and practices and a Gesellschaft that is instead a product of the will, what he calls a Willensgemeinschaft as counterpoised to a Schicksalsgemeinschaft (Krois 1979). A political myth, Cassirer affirms by referring to Doutté's anthropological analysis of magical and religious practices, is a "collective desire personified" (Cassirer 1946: 280). But if myth is a collective desire how can the emergence of such a desire be explained in the case of the "Myth of the Twentieth Century"?

Cassirer's answer is twofold. First, political myths are "desperate means". The retum of myth, he affirms, is only explainable as the last resource for facing a situation of deep crisis when the rational means are out of disposal. According to him, "In desperate situations man will always have recourse to desperate means - and our present-day political myths have been such desperate means" (Cassirer 1946: 279). And again, by depicting the situation with even clearer colours, he wrote

"[With the advent of modernity] the mythical organisation of society seems to be superseded by a rational organisation. In quiet and peaceful times, in periods of relative stability and security, this rational organisation is easily maintained. It seems to be safe against all attacks. But in politics the equipoise is never completely established[...].In all critical 
moments of man's social life, the rational forces that resist the rise of the old mythical conceptions are no longer sure of themselves. In these moments the time for myth has come again. For myth has not been really vanquished and subjugated. It is always there, lurking in the dark and waiting for its hour and opportunity. This hour comes as soon as the other binding forces of man's social life, for one reason or another, lose their strength and are no longer able to combat the demonic mythical power" (Cassirer 1946: 280).

However, Cassirer himself realises that this is not yet an answer. To say that myth has returned because rational means appeared to be out of disposal, even if one accepts this dichotomy of myth versus rationality, it is not yet an explanation of why this happened. Thus Cassirer is led to look elsewhere and precisely to the power of what he calls the "new techniques of power". So he wrote, "Myth has always been described as the result of an unconscious activity and as a free product of imagination" (Cassirer 1946: 282). And Cassirer, we should note, with his definition of political myth as a "collective desire personified" was the last one to follow this line.

The passage in question, though, continues with an important "but": "But here, observes Cassirer, we find myth made according to plan. The new political myths do not grow up freely; they are not wild fruits of an exuberant imagination. They are artificial things fabricated by very skilful and cunning artisans." Here, one can then argue, Cassirer is facing a counterexample to his own previous theory of mythical consciousness. But instead of reconsidering his theory, he attributes this "anomaly" to the development of new techniques: "It has been reserved for the twentieth century, he argued, our own great technical age to develop a new technique of myth (Cassirer 1946: 282).

Thus instead of recognising the failure of his view of the mythical consciousness in dealing with political myth - a failure that is clear from the very structure of the book, he limits himself, in the last twenty pages of the book, to explaining political myth as regression into primitive forms of thinking and society as favoured by the advent of new techniques of power. By facing a myth that cannot be explained through his own reading of modernity as an exit from myth, he repairs to these "new" techniques in order to explain the success of Nazism. Among these techniques, three of them are analysed at length: the magical use of words, the use of 
rituals and finally the concourse of prophecy. As we shall see, there are reasons to suspect that all these "techniques" are not a prerogative of totalitarianism.

Let us dwell on Cassirer's analysis. First, according to Cassirer the fabrication of such a personified collective desire as that of the Aryan race is only explainable by referring to a change in the function of language operated by Nazism. According to Cassirer's philosophy of language, there are two possible uses of words: the semantic and the magical. The former, that is the main one, consists in using a word for describing an objective state of affairs, whereas the latter consists in using words for producing certain effects. Even if the semantic function is never missing, because without it there could not be human speech, according to Cassirer, in primitive societies the magic word has an overwhelming influence. The magician or sorcerer does not describe any relation of things, but aims only at producing certain effects, at changing the course of nature: his power is therefore irresistible.

Our politicians, so Cassirer continues, therefore, unite within themselves two figures that have appeared separate until now: homo faber is now also homo magus (Cassirer 1946: 283). Cassirer does not explain how such a change is possible, he simply notes that ordinary words are charged with further meaning and that newfangled words are charged with feelings and violent passions (Cassirer 1946: 283).

But the skilful use of words, he observes, is insufficient: if the word is to have its effect, it has to be supplemented by the introduction of new rites (Cassirer 1946: 284). Again, it is the primitive societies that provide the example of a form of life vinculated by thousands of rituals and social practises: the progress of anthropological research have, according to Cassirer, falsified Rousseau's image of the savage: far from being the free and unfettered creature of Rousseau the savage is hemmed in on every side by the customs of his people; he is bound by the chains of innumerable rites grounded in tradition. The effects that all these rites produce are the obliteration of the responsibility of the subject: in primitive societies there is no individual responsibility, according to Cassirer, but only a collective one. In a similar vein, in his view, totalitarianism by deleting the distinction between the private and the public sphere, has succeed in inundating the whole life of individuals by a high tide of rituals that are as rigorous and inexorable as those that we find in primitive societies (Cassirer 1946: 284). 
Methods of repression and compulsion have always been in use in political life, but, Cassirer notes, modem myths did not begin with demanding or prohibiting certain actions: "they undertook to change the men in order to be able to regulate and control their deeds" (Cassirer 1946: 286). The modern techniques of power, so he continues, by overwhelming the individual with an ensemble of rituals suppress the sense of individual responsibility and, in this way, destroy freedom. Freedom, Cassirer argues following Kant, is not something that is given by nature but rather a task, an ethical imperative: to be autonomous. By melting the individual into the collective responsibility, they destroy the very sense of freedom but, at the same time, they relieve men from a heavy burden: personal responsibility (Cassirer 1946: 288). The destruction of the freedom of the subject and its autonomy is the sign that we are leaving modernity: the advent of the new techniques of power represents then for Cassirer a fall into primitive forms of life.

Cassirer's analysis gradually becomes more and more rich, but still does not fully explain how such a deep change, if it represented as he argues such a revolution, was possible: why, in other words, did modern individuals accept to exchange their freedom for a return to "primitive" forms of life?

The new politicians are identified by Cassirer with the magicians of primitive societies. The new sorcerers do not only use words in a magical way, but they also promise the medicine to cure all evils. This leads Cassirer to the third feature of the new techniques of myth: the sorcerer, the homo magus is at the same time the homo divinans. He does not only provide the cure for everything: he can also reveal the will of gods and foretell the future. Again a parallel between primitive and modem societies is introduced:

"To be sure, we no longer have the primitive kind of sortilege, the divination by lot; we no longer observe the flight of birds nor do we inspect the entrails of slain animals. We have developed a much more refined and elaborate method of divination - a method that claim to be scientific and philosophical. But if our methods have changed, the thing itself has by no means vanished. Our modem politicians know very well that the great masses are much more easily moved by the force of imagination than by the sheer physical force. And they have made ample use of this knowledge. The politician becomes a sort of public fortuneteller. Prophecy is an essential element in the new technique of rulership. The most improbable or even impossible promises are made; the millennium is predicted over and over again" (Cassirer 1946: 289). 
Reading this passage one cannot but think of our contemporary political techniques: at first sight it seems as if it is still the case that "the most improbable and impossible promises are made" and "the millennium is predicted over and over again."137 We will come back to this point later on, but it is now important to stress that there are some reasons to suspect that Cassirer's statement's "prophecy is an essential element in the new technique of rulership" seems still to hold true (Cassirer 1946: 289). This suggests that the Nazi's recourse to prophecy is not an anomaly in modernity: far from being a prerogative of totalitarianism, it seems to be part of the most different techniques of power.

Cassirer continues by analysing the way in which philosophical conceptions such as that elaborated by Spengler's in his Der Untergang des Abendslandes and even Heidegger's idea of human beings being thrown into the world (which he expresses through the neologism Geworfenheit) could have fomented in their readers a prophetic sense of fatalism that prepared the way for the "new prophets". What is interesting here is to note that when Cassirer moves on to specifically analysing the way in which the new myths work, all the dichotomies that he built before break down. For instance Spengler's catastrophic prophecy cannot be grasped through a dichotomy such as "semantic" versus "magic" uses of the word. Cassirer himself could not but admit that Spengler's words, even if they were not directly aimed at dominating people's deeds and minds, worked both as semantic and magic devices: they were at the same time describing a presumed state of affairs, the decline of the West, and producing effects in their readers. Thus, as Cassirer notes, the great success of Spengler's book, must lay in its title more than in its content: the title Der Untergang des Abendlandes was an "electric spark" that set the imagination of Spengler's readers aflame. ${ }^{138}$

On the other hand, in light of Wittgenstein's philosophy it appears legitimate to ask whether the distinction between a semantic and a magical use of the word is possible at all. As Wittgenstein's critique of the possibility to explain

${ }^{137}$ On this point, see in particular Chapter 12.

${ }^{138}$ Cassirer analysis of Spengler's success cannot but draw our attention to the success of the "prophets of our time": it seems as if the success of books such as "The Clash of Civilisations" or "The End of History" depends on their titles rather than their content: like Spengler's book, titles like the "The Clash of Civilisation" or "The End of History" set the readers' imagination aflame before appealing to their intellect. On this point see Chapter 12. 
meanings on the basis of merely ostensive definitions has shown, there cannot be meaning without a whole made of language and actions, i.e. language-games. The meaning of a word is its use, and its use is always aimed at describing something by producing certain effects and vice versa. To put it in Cassirer's terminology, there cannot be a semantic without a magical meaning use of words.

The point is that, as we have seen, Cassirer's general philosophy is still within the Enlightenment's presupposition of a philosophy of the subject. In his view, the two main forms of experience of meaning are the mythical and the scientific consciousness, and the distinction between the two is drawn on the basis of the possibility to distinguish between the subject and the object of the representations. Whereas, as we have seen, according to his Philosophy of Symbolic Forms, scientific representations (Vorstellungen) are based on a clear distinction between the subject and the object of knowledge, in mythical consciousness the subject is overwhelmed (überwältigt) by its object, and this explains why, according to him, it can have a magical impact.

Thus, against those who sustain that Cassirer's general philosophy is not a philosophy of the subject because he points to the social character of the mythical consciousness (Krois 1979: 203), it can be argued that, quite on the contrary, Cassirer still remains within the presuppositions of a philosophy of the subject because he conceived the myth in such a totalising way precisely because he counterpoised it to the scientific representations: he does not conceive of the subject of mythical representation in a "solipsistic" way, precisely because he counterpoised it to the "solipsistic" subject of scientific enquiry. In this, he thus remains within the Enlightenment.

From the point of view of a theory of political myth, the problem seems to be that by analysing myth as a form of consciousness or as an entire form of life the differences between phenomena such as myths, religious beliefs and practices as well as rituals of all sorts, all get lost. But in fact, myth, religion and rituals are different things. First myth is not religion and, if it can be argued that human beings are überwältigt by a religious representation that pretends to an ultimate truth, the same does not hold for myth. ${ }^{139}$ By leaving aside a discussion of the issue in terms of a

\footnotetext{
${ }^{139}$ A similar point is made by $\mathrm{H}$. Tudor when he observes that it is not true as Cassirer argues that in myth all reality and events are projected into the fundamental opposition of the "sacred" and the "profane"since, as he points out, there are many myths in which the sacred plays no role whatsoever (Tudor 1972: 35). The reason
} 
subject-object relationship, it can be sustained that mythical constructions are not impenetrable by rational arguments: Cassirer's own critique of "modern myths" demonstrates precisely the contrary.

Secondly, the two categories of myth and rituals must also be kept separated. In fact, even if the Arbeit am Mythos can only be grasped by looking at its working from the point of view of its being a language-game made of language and action, the concept of rituals brings in a new dimension that is not entailed in the concept of myth. As we have seen, ritual is not any action. Only a particular class of actions can be classified as rituals. Rituals, from the Latin word rite, is literally "what is well done", or "what is done according to the rules". Thus, even if political myths and political rituals are quite often associated, the two work in quite different ways within a society: whereas political rituals must be kept unchanged to be effective, political myth in as far as it provides significance to an always changing world, must remain open to the possibility of being renegotiated according to new experiences and needs. To put it bluntly, a political myth expresses itself through variants, the political ritual through fixed rules. ${ }^{140}$

Hence it can be argued that it is precisely because Cassirer remained linked to the Enlightenment dichotomy of "mythical consciousness" versus "scientific consciousness" that he cannot but analyse Nazism's use of myth in terms of "the return of demonic forces", i.e. as regression (Cassirer 1946). Only by following the Enlightenment identification of myth with all that which pure reason is not, i.e. with a whole form of life entailing religion as well as magic he could have assumed that, since modemity has undermined the role of religion, it should have also got rid of myth.

At the beginning of the twentieth century and thus well before the Myth of the State, another book was published where an alternative theory of political myth was developed. It is Sorel's Réflections sur la violence (1908). ${ }^{141}$ Its major argument about political myth is that myth is not religion, and it is precisely for this reason that

\footnotetext{
why Cassirer argued this is that he saw in the modern totalitarian myth maker "the priest of a new, entirely irrational and mysterious religion" (Cassirer 1946: 282). But myths, despite all the enthusiasm they can inspire, are not a form of religion. A similar point is made by another contemporary theorist of political myth, C. Flood who distinguishes between political myth and what he calls "sacred myths" (Flood 1996).

${ }_{140}$ On the distinction between myth and ritual in general see Chapter 6.

141 According to some interpreters Sorel's Reflections on violence remains "the most interesting attempt to elaborate the notion of political myth" (Tudor 1972: 12).
} 
it can and should play a role in politics. Whereas Cassirer saw in myth a form of "regression", Sorel presents political myths as a form of "progress".

Sorel, in contrast to Cassirer was not a professional philosopher. In all his writings, he is continually taking a polemical distance from "les Intellectuels" or "les Hommes d'école" (Sorel 1908: 7). The Réflections sur la violence, a collection of articles previously written in the context on the discussion on syndicalism, clearly have an activist intent: to develop a severe critique of the parliamentary socialists and their neglect of the primary role played in history by proletarian violence. In Sorel's view, it is proletarian violence, and not the sophisticated moves of parliamentary socialists, that is the real engine of history. And the myth of general strike is the highest point of proletarian violence, a complex of images able to immediately evoke all the different manifestations of the war engaged by socialism against capitalism.

Sorel's reasoning is quite straightforward:

"In the course of these studies, he wrote, we ascertained something that looked so simple that we have not been insisting too much on it: human beings taking part to big social movements represent their own future action in the form of images of wars assuring the triumph of their cause. I proposed to call myths these constructions whose knowledge is so important for the historian: the general strike of syndacalists and the catastrophic revolution by Marx are such myths" (Sorel 1908: Introduction, III: 21).

According to Sorel the action engaged by human beings in big social movements cannot be explained without powerful images such as myths: the more dramatic the action, the more powerful these images. In as much as the Christian martyrs were moved by the catastrophic representation of the Apocalypse, so the passage from capitalism to socialism must take the form of a catastrophe in order to be effective as a pouvoir moteur (Sorel 1908: 143).

Why, one can ask, should we use the concept of myth to describe these images? First, it can be argued that Sorel meant here to take distance from all kinds of positivistic explanations. There are facts, according to Sorel, that cannot be explained by an "intellectualist philosophy", which he, in other places, also indicated as being "petite science" (Sorel 1908: 23). The readiness to sacrifice their own lives shown by the Napoleonic soldiers or by the Greeks and Romans cannot be explained on the basis of purely rational explanations. In order to explain them, according to Sorel, we must have recourse to Bergson's explanation of the way in which human 
beings create an artificial world that is placed in the future and that is formed by movements depending entirely on us (Sorel 1908: 28). Sorel refers to Bergson's psychology in order to explain the way in which it is possible that such complexes of images are formed. These images, thus, in Sorel view's depend only on movements within the subject, i.e. a sort of Bergsonian élan vital, and precisely for this reason they are defined as myths. This also enables him to distinguish these images both from utopia and religion.

The general strike is a myth and not an utopia precisely because it is not a theoretical model: the general strike is a "determination of the will". A myth is not the construction of the single mind of a theorist who, after having observed and discussed facts, establishes a model for comparing existing societies and measuring the good and bad they contain (Sorel 1908: 30). A myth cannot be divided in its parts and judged according to their correspondence to reality or their feasibility: a myth, in Sorel's terms, is a whole made of images that only together can express a specific determination of the will.

What interested here the revolutionary syndacalist Sorel was indeed to understand in what conditions a socialist revolution is possible. In this respect it is crucial for him to distinguish myth from utopia. So he states that despite the fact that socialism has been a utopia for a long time, it has now reached a completely different stage: socialism, in his view, is no longer utopia because it became a preparation of the proletarian masses that wanted to suppress the state and property (Sorel 1908: 35)

Thus, if on the one hand, the general strike is no longer a utopia because it is now a determination of the will, it must also, on the other, be distinguished from religious beliefs. Sorel explicitly wrote that "people living in this world of myths are secure from refutation; this led many to assert that socialism is a kind of religion. For a long time people have been struck by the fact that religious convictions are unaffected by criticism and from that they have concluded that everything that is below science must be religion" (Sorel 1908: 35 ). ${ }^{142}$ But not all that which is not science is religion.

Sorel, in contrast to Cassirer emphasises the point: this enables him to recognise the role of myth in modern politics. Thus, whereas Cassirer, by moving

142 Curiously, the English translator rendered the French "au-dessous de la science" with "beyond science", whereas the fact that Sorel posits myth and religion au-dessous and not "beyond" the level of science is, as we will see, very significant. 
from the self-narrative of an enlightened reason that unifies under the heading of "superstition" or "mythical consciousness" all that which is not grounded on scientific reason, is unable to explain the presence of myth in modern societies and in the face of the tragically conspicuous role played by the myth of the Aryan race he cannot but interpret it in term of "regression" into myth. Sorel by distinguishing myth from religion is able to recognise the presence of myth in modern societies and even to see in them a form of progress. If modernity has undermined the role of religion as a horizon of sense in the experience of the world, it has not in any way undermined that of myth. Quite on the contrary, it is precisely in typically modern phenomena such as the big social movements that the role played by mythical constructions became evident. It is only because people taking part in big social movements can represent their action as an event within a narrative assuring the triumph of their cause that they engage in such actions as the proletarian struggle. "These results, Sorel wrote, could not be produced in any certain manner by the use of ordinary language; use must be made of a body of images which, by intuition alone, and before intellectual analyses are made, is capable of evoking as un undivided whole the mass of sentiments which correspond to the different manifestations of the war undertaken by socialism against modem society" (Sorel 1908:131).

Thus, it is not important to know whether the single details that form a myth will actually be part of the future history. It might even be the case that nothing which they contain will ever happen: this will not undermine their pouvoir moteur. Also, as in our everyday day life we continuously make experience, Sorel observes, there is a huge gap between what actually happens and our preconceived notion of it, and this does not prevent us from continuing to make resolutions. Myth, to conclude, according to Sorel, must not be judged as an astrological almanac making previsions about the future, but as means of acting on the present (Sorel 1908: 135).

But if it is true that myths cannot be falsified, they on the other hand can be discussed. Sorel is ambiguous on this point, but in different places he seems to conceive of myth as an absolute dimension beyond the possibility of discussion. For instance he goes as far as to write that "the idea of the general strike is so admirably 
adapted to the proletarian mind than can dominate it in the most absolute way [...] and that even the power of dispute is reduced to nothing" (Sorel 1908: 122). ${ }^{143}$

In fact, this statement contrasts precisely with what Sorel does, that is rationally discuss a myth. In particular, in the fourth article of the Réflections sur la violence, an article devoted to the defence of the general strike against the criticism of many parliamentary socialists, Sorel discusses the myth of the general strike from the point of view of its rationality. Sorel defends this myth by showing how it corresponds to Marx's doctrine. In Sorel view, the general strike is well adapted to convey in an immediate image all the most important views and values of this doctrine: the division of the society into two classes, whose interests oppose each other, the idea of class struggle, the revolution of the present state of things. This is a crucial point that can be grasped only by looking at the same time at what Sorel actually says about the myth of the general strike and what Sorel actually does with it. If one looks at both dimensions it becomes impossible to sustain that for Sorel myth is only a matter of faith that eludes any possibility of critical discussion (Tudor 1972: 15): to critically discuss myth is precisely what Sorel does in his work.

The reason why he, at different points, in contrast to what he himself does, seems to hold that myths are not subject to rational discussion is that he remained linked to what we can call a "dualistic view of the self". Referring to Bergson's psychology, he interprets it according to a theory of the two selves. As we read in the Introduction to the Reflections, according to Sorel there are two different selves: on the one hand the free creative side and on the other the rational, external and spatial one. It is to this latter that the stable affirmations of science are due, whereas myth is the product of the other self (Sorel 1904: Introduction).

Sorel on the other hand, does not go much further than this very brief reference to Bergson's psychology: he was not so much interested in the psychological implications of his theory of myth than with its practical ones. His major point was to show that the proletarian violence is the real engine of history and, to this end, he points to the pouvoir moteur of the general strike. In doing this, though, he does formulate a theory of political myth for he recognises that there cannot be a mobilisation of political action without a powerful set of images that

\footnotetext{
${ }^{143}$ In other places for instance Sorel defines myth as a total experience (une expérience intégrale) that cannot be permeated by rational arguments (Sorel 1908: 124).
} 
assure to those who are engaged in that action the certainty that their cause will triumph. When these images, as it is in the case of the myth of general strike, assumes a narrative form and when it aims, by inserting events in such a narrative, at creating significance, then we can talk of a political myth. On the other hand, Sorel does not deeply investigate the psychological implications of such a view: for the point he wanted to make in the Reflections, some scattered references to Bergson were enough. And this is the reason why the psychological theory of the two selves to which he refers remains inadequate to support his analysis of the role that is played by those complexes of images that constitute a political myth.

Despite the dualistic view of the human mind implicit in the theory of the two selves, his own analysis of political myth in fact goes well beyond such a view. Sorel's explicit conception, and even less what he actually does when dealing with the myth of the general strike, cannot be grasped through a dualistic approach. Gramsci points to this when he criticises Croce's interpretation of Sorel. Croce himself thought of myth as the product of a sphere of human mind - i.e. the sphere of passions - which is impenetrable by rationality and for this reason he sustained that Sorel, by rationally discussing the myth of the general strike, dissolves it (Gramsci 1975, II, Quademo 10,41). To this view, Gramsci replies that only such an intellectualistic and idealistic approach as that of Croce could have assumed this. In Gramsci's view, the myth of the general strike is neither a mere piece of paper (una cosa di carta) that could be dissipated by some doctrinarian pages, neither the expression of a set of passions impenetrable by rational discussion (Gramsci 1975, II, Quaderno 10,41). Why, one could argue following this line of reasoning, should we assume that reason has not its own passions and that vice-versa passions cannot be reasonable? Why should the passions disappear when rational considerations come in? Any dichotomy of "passions versus reason" reveals its serious limitations here. What Sorel does whilst discussing the myth of the general strike is no different from what we all do when reflecting upon a future course of actions: to consider its correspondence to our own views, values and passions, without it being possible to separate between all these components. Far from dissolving myth, by discussing its correspondence to Marxism, Sorel reinforces it: he shows what is implicit in this narrative, the morals of the story, and thereby he reinforces the belief in it and thus the determination to act correspondingly. 
A more elaborated theoretical framework for a theory of political myth can be found in Spinoza's thinking. Whereas, most early modern political philosophy neglected or marginalised the role of political myth, a fully developed theory of political imagination can instead be found in Spinoza's Tractatus Theologicuspoliticus (1670). As Pierre Francois Moreau recently pointed out, to witness such a detailed analysis of the symbolic conditions of the existence of a polity and such an emphasis on the logic of adhesion and identity we would have to wait for the twentieth century, with Hannah Arendt and Jürgen Habermas (Moreau 1994: 495).

Now maybe we do not have to wait until Arendt, since sociology, for instance, from its very beginning has largely dealt with such phenomena ${ }^{144}$; but Moreau rightly points to the fact that Spinoza does constitute an anomaly within modern political theory: not only for his radical theory of democracy but in particular because, in contrast to other modern philosophers, he goes as far as to deeply investigate the symbolic conditions for the conservation of political power. In the fifth chapter of the Tractatus Spinoza clearly states that all kinds of state laws must be instituted in such a way that human beings are bound not by fear (metu) but by hope in something that they desire in a particular way (spe alicuius boni, quod maxime cupiunt). ${ }^{145}$ Spinoza's theory of political imagination can be considered as a reflection on the problem of how such a hope can be socially created.

To this end, Spinoza analyses the role that prophecy played in the creation and conservation of the ancient state of Israel. The approach that Spinoza adopts though in this analysis is not theological, but theological-political, or, to put it in more contemporary terms, "sociological". Spinoza is not interested in defending the truth of the Jews' prophecy, but in analysing the role that it played within society. Thus, as it has been argued, from this point of view Spinoza inaugurates the modern study of religion (Preus 1989: 72). ${ }^{146}$ From the very outset, Spinoza describes the method that he employs in the interpretation of the Scriptures on the basis of two premises. The first can be described as a shift from an approach to the truth of the

\footnotetext{
${ }^{144}$ One just has to think of Durkheim whose analysis of the role of religion on primitive society has many points of contact with Spinoza's. On the other hand, also the romantic theories of the polity focus on these kinds of problems.

${ }_{145}$ See Spinoza 1670, V, 20. There are many places in the Tractatus where Spinoza makes a similar point. Here the critique seems to be directed towards Hobbes.

${ }^{146}$ On this point see for instance Preus 1989: 72; Lang 1989: 296. Lang argues that the theory of interpretation of the Tractatus is an anticipation of the modernist turn towards a politics of interpretation.
} 
text to one focused on its meaning, and the second as the recognition of the contingency of meaning, i.e. of the fact that meaning is contingent because the text is contingent (Lang 1989: 328ff).

Firstly, Spinoza explicitly states that, in the interpretation of the Bible - and by implication of any text - we are in the first instance "at work not on the truth of passages, but only on their meanings" (Spinoza 1670, VII 100-101; XII 17-171 and 163). Two extremes must thus be avoided when interpreting the scripture: on the one hand that of the "dogmatists", those rationalists or philosophical allegorists, who, in order to save the truth of the text, attribute to the prophets what they never even dreamed of; and, on the other hand that of the of the sceptics, i.e. those literalist interpreters who force us to accept as divine utterances all the possible prejudices of the ancient vulgi (Spinoza 1670: XV, 190/180). ${ }^{147}$ Both these interpreters, according to Spinoza, are concerned more with the truth of the text that with their meaning and they fail to understand the contingent character of meaning. God, though, does not have a style, Spinoza repeats in many places, and therefore all differences and incongruities of the Scripture cannot but be attributed to the contingency of the context in which the texts have been written. But since meaning cannot be separated from use, and thus from its context, then meaning itself must be contingent.

Meaning, in Spinoza's view, is contingent because it is determined by the use of a word. This view leads Spinoza as far as to say that the Scriptures can be said to be "sacred" only in as far as they are designed to promote piety, and continues to be sacred only as long as it is "religiously used". As we read in a passage that could have been written by Wittgenstein:

"Words have a certain meaning only on the basis of a certain use (verba ex solo usu certam habent significationem), and if they are arranged, according to their use, in such a way as to move those who read them to devotion, they will become sacred, and the book so written will be also sacred. But if their usage afterwards dies out so that words have no meaning, or the book becomes utterly neglected, whether from unworthy motives, or because it is no longer needed, then the words and the book will loose both their use and their sanctity" (Spinoza 1670: XII, 20).

According to Lang, Spinoza not only argues that interpretation presupposes or implies a political framework, but even that interpretation is itself a politics. For our purposes it is not necessary to go as far as this.

${ }^{147}$ The similarities between Spinoza's criticism of the literalist and dogmatist as interpreters and Vico's criticism of the "two conceits" have been noted: that of nations who pretend that their own myths are literally tue corresponding to the form, and that of scholars who maintain that what they know is as old as the world, i.e. that the rationality with which they now apprehend the world was shared from the very beginning (Preus 1989). On Vico's two conceits see Chapter 5. 
Spinoza's analysis of the role of prophecy for the ancient Hebrews is thus the occasion for a more general reflection the social nature of meaning. Spinoza, who was excluded from the Jewish Community in Amsterdam, could largely work free from those ordinary constraints that in Europe of the time determined popular as well as scholarly perspectives on religion. He does not have to bear the apologetic burden to save the religious meaning of the text he studies or of the people that have produced them (Preus 1989: 72). This puts him in the condition to be able to adopt a genuinely critical approach towards the texts so that many authors have seen in his analysis the origins of modem critical theory (Norris 1991, Hippler 2000).

Biblical prophecy, according to Spinoza does not derive, as Maimonides sustained, from a particular kind of knowledge. Prophecies are not the result of a divine revelation since no divine revelation, as traditionally understood, exists: God does not have a particular style and He adapts himself to the particular circumstances of the linguistic and historical context in which prophets live. Thus, their obscure, enigmatic and figurative character derives not from God, but from the vivid imagination of the prophets. As a consequence, in order to prophesise one must not have a more perfect mind, but a more vivid imagination (ad prophetizandum non esse opus perfectiore mente, sed vividiore imaginatione) (Spinoza 1670: I, 25).

On the other hand, as has been recently pointed out, imagination, in Spinoza's view, is not "imaginary", i.e. false (Hippler 2000: 97). Imagination, according to his Ethics, is simply a set of ideas produced on the basis of present or past bodily impressions and as such it is not necessarily false. In its turn, an idea is a "concept of the mind" (Ethics II, def. III) and the mind is nothing other than an expression of the body - the body that is felt and thought (Ethics II, prop. 13). As is well known, the mind and the body are in Spinoza's view simply two attributes of Gods, i.e. the ways in which God, the unique substance, is given to us. Furthermore, according to Spinoza, the structure of the two attributes is parallel: "the order and connection of ideas is at the same time the order and connection of things" (Ethics II, prop. 7$)^{148}$.

\footnotetext{
${ }^{148}$ As it is well known, the polemical objective of this conception is Descartes's radical dualism of the res cogitans and res extensa. It would be interesting to further investigate the link between Spinoza's radical monism and his conception of political imagination: prima facie there seems to be a strict link between his ontology and his denial of the purely "imaginary" character of imagination.
} 
The parallelism between body and mind, or extension and thinking, does not mean though that all ideas are adequate. Quite on the contrary, what characterises imagination is precisely its inadequacy: imagination, in Spinoza's theory of knowledge, is in fact only the first level of knowledge. Nevertheless, even if these ideas are not yet adequate, since it is only through intellectual knowledge that adequate ideas can be obtained, they are not necessarily false, because a mind has false ideas only in as far as it considers these bodily perceptions to be adequate ideas when they are not (Ethics, II, 24, 27-31). Thus, if imagination cannot be considered as adequate knowledge, it nonetheless plays an extremely important role in the sphere of praxis.

As Spinoza points out, prophetic imagination concerns the practice of life and virtue and the authority of the prophets is based on this moral role (Spinoza 1670: II, 30). As he openly states, the certitude stemming from biblical prophecy is a moral one: "the certitude deriving from the sign in the prophets was not mathematical, i.e. it was not the certitude that derives from the necessity of the perception of an object, but rather moral" (Spinoza 1670: II, 32, 10). Spinoza repeats in many places that the intent of the scripture is mainly a moral one and the certitude of the prophets derives from the fact that "their mind was totally given to what was right and wrong" (Spinoza 1670: III, 31, 30).

It has been sustained that since, for Spinoza, the categories of good and right do not exist outside of a political community, one can conclude that prophecy is valid because the prophet belongs to a community whose laws and rules he precisely embodies (Hippler 2000: 99). Thus, the social function of prophecy is to recall these norms in the memories of the members of society. But if the prophets can be prophets only in the community whose norms they embody and if, on the other hand, the aim of prophecy is precisely to strengthen the community's adhesion to those same values, then the prophets and the community are products of each other, i.e. they have a purely circular relationship (Hippler 2000:100).

A similar interpretation of this point that seems to suggest, on the other hand, a way out of this circularity has been put forward by Michael A. Rosenthal. In his view, Spinoza chooses the example of the Hebrews because the analysis of the role of prophetic language enables him to make a general point about the way in which an appeal to an imaginative narrative example contributes to justifying a 
particular set of institutions: when the prophets called the Hebrews "the chosen people" they were performing a function essential to any society, i.e. they were using imagination to transcend individual interests and to create a common standard of judgements and behaviour (Rosenthal 1997).

The concept that enables making this passage is that of the exemplar of human nature, a concept which is developed by Spinoza in the fourth part of the Ethics (Rosenthal 1997: 247). Here Spinoza defines "good" and "bad" from the point of view of utility: "By good I shall understand what we certainly know to be useful to us" and "by evil I shall understand what we certainly know prevents us from being masters of some good" (Ethics IV, d.1, d.2). Clearly the problem arises of how to determine this utility because what is useful for one person at any given time and place may not be to another. So if the value terms "good" and "bad" are to mean something more than the mere subjective utility of an individual, then it is necessary to find a basis for transcending the particular judgement of the individual; this is the purpose of the concept of the "exemplar of human nature".

Thus after the above mentioned definitions of good and bad, Spinoza points the reader back to the preface of the fourth part of the Ethics where he says "I shall understand by good what we know certainly is a means by which we may approach nearer and nearer to the model (exemplar) of human nature that we set before ourselves. By evil, what we certainly know prevents us from becoming like that model." Spinoza then further explains that exemplars, thus defined, serve as a bridge from subjective to objective judgement because they are formed not on the basis of an individual judgement, but on the basis of a universal idea (Ethics, IV, Pref.).

What is a "universal idea" according to Spinoza? As Rosenthal points out, according to Spinoza so-called "universal ideas" are not "adequate ideas", i.e. the clear and distinct foundations of reason, but they are rather inadequate ideas, incomplete and confused images of the world. Spinoza distinguishes between "common notions" which are the foundations of our reasoning, on the one hand, and notions that derive from other causes and are therefore ill-founded, on the other (Ethics II, pr.40). Despite their names, "these notions are not formed by all [human beings] in the same way, but vary from one to another, in accordance with what the body has more often been affected by, and what the imagination recollects more easily" (Ethics II, pr.50). Thus universal ideas can also be characterised as the 
notions "we are accustomed to feign" (Ethics IV, pref.) and should therefore be called "beings of imagination" rather that "beings of reason" (Ethics I, appendix).

Spinoza's notion of the exemplars of human nature cannot but recall Vico's concept of "imaginative universals". In both cases we have certain constructs of the imagination that far from being simply individual creatures aspire to be universal in their nature. In both cases we have universal beings of imaginations. It is precisely due to this "universality" that they can serve to mediate between individual and universal judgements. In tum, this conception of imaginative universals cannot but recall Aristotle's conception of myth as developed in the so-called Poetics. As we have seen, mythoi, according to Aristotle, are superior to history precisely because whereas this latter tells things as they happened, mythoi tell them as they could have happened and for this reason they contain a more universal truth. ${ }^{149}$ This, in Aristotle's view, is the "universality" of the knowledge of different human characters, or, to put it in Spinoza's terms, the knowledge of the different "exemplars of human nature".

Whereas Vico, by historicizing his analysis of the role of imaginative universals and attributing it to the childhood of humankind, limits his theory of imaginative universals to a certain historical phase of humankind, ${ }^{150}$ Spinoza, like Aristotle, considered the power of imagination to create order as a normal feature of human beings at any time and in any society. This is the reason why Spinoza's analysis of the role played by imagination in prophecy can become the basis for a more general theory of political imagination. The example of Jewish prophecy is the basis for constructing a whole theory of political myth: a theory that consents both to reconstruct the role that myth plays in politics but also to set the limits for the legitimacy of its use. Instead of labelling political myth as a form of "regression" or "progress", Spinoza's elaborate theory provided the means for analysing the conditions of their use.

The fact that Spinoza understood his analysis of the history of the ancient Hebrews as a basis for a more general theory is made patent in the structure of the Tractatus. Indeed the text, after having dealt with all aspects of the constitution of the state of Israel, ends with a chapter on the Principles that can be drawn from the

\footnotetext{
${ }^{149}$ See above Chapter 3.

${ }^{150}$ For an analysis of Vico's view of myth see above II, 2. On the possible influence of Spinoza on Vico as well as on the difference between the two see Preus 1989.
} 
Hebrews' history followed by another two chapters devoted to showing, on the basis of that example, that freedom of thought and speech does not harm the state but is instead fundamental to its survival (Spinoza 1670, XIX, XX). From the very preface to the text Spinoza clearly states that the aim of the Tractatus is precisely to argue for the freedom of thinking and speech: Spinoza's main argument is indeed that, if all societies are in a sense imaginary, where imagination implies an inferior and still confused kind of knowledge, what they differ in is the degree to which this imagination is subject to critical scrutiny. Thus despite the fact that most of the people live at the level of imagination, the state should guarantee the possibility to those who can to elevate themselves to higher levels of knowledge and exercise a critical function (Spinoza 1670, pref, XIX, XX). What Spinoza actually does in his critique of the sacred scriptures is precisely this.

In doing so, Spinoza wanted to make a general point about the role of political imagination, but the reason why he chooses the Hebrews is also linked to the particular circumstances in which he wrote. It has been shown that the seventeenth century Dutch saw themselves in the light of three important sets of narratives or myths: their heroic struggle against the Spanish, the story of the Batvians depicted in the writings of Tacitus (and other Roman historians) and drawn upon by Grotius (among others) and, finally, the story of the ancient Israelites (Rosenthal 1997: 267). It is in reference to this latter founding myth that Spinoza chooses the Hebrews: his contemporary Dutch Calvinists had spread the belief that their nation was chosen to endure and triumph over their travail in order to maintain a certain political order. Spinoza's use of the ancient Israelites is meant to be the basis for analysing and setting the limits to the legitimate use of such political myths.

Let us develop this point by going back to the analysis of Jewish prophecy. According to Spinoza's reconstruction, after the exit from Egypt the people of Israel had fallen again into a pure state of nature, because having left the laws of the Egypt to which they had been subjected hitherto they had not yet been able to build other laws. In this context, Moses had called the Hebrews "chosen" and has used the idea of the covenant with God as a means of morally inciting his people to subject themselves to a lawful condition. This use made by Moses was, according to Spinoza, legitimate because the Hebrews were by that time a lawless band of people cast out into the desert, and Moses, in order to give them a law, had to place their 
particular experience into a framework of a divine plane in which they played a special role.

People listened to prophecy because it provided them with a consistent set of expectations about the results of their action. The recourse to prophecy was thus necessary because the Israelites in that situation were not able to otherwise perceive the necessity of a polity. So, Spinoza observes "if any one wishes to persuade his fellows for or against anything which is not self evident, he must deduce his contention from their admission, and convince them either by experience or by ratiocination [....] But the deduction of conclusion from general a priori truth, usually requires a long chain of arguments, and moreover very great caution, acuteness, and self-restraint - qualities which are not often met with; therefore people prefer to be taught by experience rather that deduce their conclusion from a few axioms. Whence it follows that if anyone wishes to teach a doctrine to a whole nation (not to speak of the whole human race), and to be understood by all men in every particular, he will seek to support his teaching with experience and will endeavour to suit his reasoning and the definition of his doctrines as far as possible to the understanding of the common people, who form the majority of mankind" (Spinoza 1670, V, 70). Thus, given that only the learned can elevate themselves to intellectual knowledge, whoever wants to communicate to a whole nation has to have recourse to imagination.

This does not mean that these histories are necessarily false: on the contrary the reference to imagination as a way to "teach by experience" leaves open the issue of the truth of these images. Spinoza also explicitly admits the possibility that the content of such stories is true: the only point is that only s/he who can reach the level of intellectual knowledge will also have a concept of them as "clarum et distinctum" (Spinoza 1670, V78). The Scriptures, whose true moral content, according to Spinoza can be summarised in very few principles, were written for an entire people and therefore had to communicate through stories appealing to people's imagination. On the other hand, those very few principles could also be grasped with the lumine naturali; this, in his view is reserved for the leamed few. This, Spinoza explicitly argues, is the sense of the histories of the Bible: to inspire devotion and obedience 
(Spinoza $1670, \mathrm{~V}, 78 \mathrm{ff})^{151}$. As a consequence the populace (vulgus) must not know all the stories of the bible, but only the stories "that can move their mind to obedience and devotion in the strongest way (quae maxime eorum animos ad obedientiam et devotionem movere possunt)" (Spinoza 1670, V, 79). In the case of the Hebrews cast out in the desert, among those histories were the prophetic histories of their "chosenness".

Biblical prophecy therefore played a double role for the Hebrews in the particular situation in which they found themselves. First, like all the other stories from the Bible, they transmitted a moral message. Second, the story of their "chosenness", by addressing their particular needs, contributes to grounding - again in the sense of begründen - the specificity of their polity: theocracy. The biblical prophecy by recalling to the Hebrews their covenant with God made respecting the law appears necessary.

In this sense, it does not differ from other political myths to which Spinoza refers. Among them, he quotes for instance the Roman foundation myth: all the kings, Spinoza observes, that have usurped the power have always tried to make the people believe that they had divine origins: only if the people could think that these rulers were Gods could they have bome their government. This is the reason why August let the Romans believe that he was Aeneas' descendent (Spinoza 1670: XVIII, 204). Thus, the prophecy is only one of the possible ways in which "to arrange laws so that people are kept in bounds by the hope of some greatly-desired good, rather than by fear, for then everyone will do his duty willingly" (Spinoza $1670, \mathrm{~V}, 74)$.

To this end, Moses also introduced the ceremonial laws. After having analysed the use made by Moses of prophecy, Spinoza observes:

" Lastly in order that the people which could not govern itself be entirely dependent on its ruler, he left nothing to the free choice of individuals (who had hitherto been slaves); the people could do nothing but remember the law and follow the ordinances laid down at the good pleasure of their rulers; they were not allowed to plough, to sow, to reap, nor even to eat [...].This, then, was the object of ceremonial law: that men should do nothing of their own free will, but should always act under external authority, and should continually confess by their actions and thoughts that they were

\footnotetext{
${ }^{151}$ It should be noted that Spinoza in order to assert that the Scripture teaches certain principles through the narrations of histories he uses the expression "Atque heac Scriptura sola experientia comprobat, nempe his quas narrat, historis", i.e. these things are proved by the Scripture only through experience, that is through the stories that they tell.
} 
not their own masters, but were entirely under control of others" (Spinoza $1670, \mathrm{~V}, 76)$.

Thus for Spinoza, like for Cassirer, political myths are also accompanied by specific rituals. The function of rituals is to continually recall to the mind of the people their obedience to the laws. This role is not though a prerogative of the Hebrews' ceremonies. A few paragraphs later, Spinoza analyses the similar role plaid by Christian ceremonies. With a passage worthy of Malinowski he wrote:

"As for the Christians rites, such as baptism, the Lord's supper, festivals, public prayers and any other observances which are, and always have been common to all Christendom, if they were instituted by Christ or his apostles (which is open to doubts) they were instituted as external signs of the universal church, and not as having anything to do with blessedness, or possessing any sanctity in themselves: even though these ceremonies were not intentionally ordained for the sake of upholding a government, they were ordained for the preservation of the society, and in fact he who lives alone is not bound by them" (Spinoza 1670, V, 76, emphasis mine).

Thus, Christian ceremonies too had nothing sacred in themselves, but they rather played a specific social function: to remember obedience to the law. In the case of the Hebrews, a people used to serfdom and that was again thrown into a state of nature, the ceremonial laws prescribed took a particularly detailed and alienated form: they had the function of remembering the subjugation to God's law and had therefore to work in such a way that in their everyday life Hebrews would continually confess that they "were not their own masters, but were entirely under the control of others".

Furthermore, Spinoza observed, all these rituals serve not only to recall in the people's mind their obedience to the law, but also to separate the Jews from other peoples (Spinoza 1670, III, 56). In particular, all these meticulous external rituals, that are different from that of other nations, kept Jews separated from all others. Among those rituals, circumcision, by writing the covenant with God on the body, played a crucial role so that, Spinoza observes, circumcision alone would be sufficient for explaining how the Jews survived as a nation through the centuries notwithstanding the destruction of their state (Spinoza 1670, V, 57). According to Spinoza, "the sign of circumcision is so important that [...] it would alone preserve their nation for ever. Nay, I would go so far as to believe that if the foundation of 
their religion had not emasculated their minds they may even, if occasion offers, so changeable are human affairs, they would raise up their state again and God may a second time elect them" (Spinoza 1670, V, 57).

By writing the obedience in their own bodies, circumcision is thus the strongest means for political discipline. ${ }^{152}$ The parallelism between the order of idea and that of things takes here the form of a sign in the body. The importance of the exterior or bodily sign is also confirmed by the reference to the Chinese that, according to Spinoza, by means of a distinctive mark on their head, which they most scrupulously observe, keep themselves apart from everyone else so that they preserved their unity even when they had no empire (Spinoza 1670, III, 57).

The reference to the Hebrews' history thus serves to draw the limits of the legitimate recourse to political myths and rituals. As for political rituals, we have seen that, according to Spinoza, the extremely strict ceremonial prescriptions that Moses gave to his people are justified only on the basis of the contingent situation in which the people of Israel was: a people cast in the desert after many years of serfdom. The institution of ceremonies served then to recall obedience to God's laws in every single act of their life for a people that, having just come out of serfdom, could not think of themselves. But in no way must these ceremonies be considered as possessing any sanctity in themselves (Spinoza 1670: V, 76). Rather, we can assume that in a polity formed by people not used to serfdom, political rituals - however necessary - must not takes such meticulous and alienating form.

In a similar vein are the contours drawn for a legitimate use of political myth. Again the history of the Hebrews - as retold by Spinoza - works as an exemplar. After the death of Moses, Spinoza says, the Hebrews' theocracy degenerated into superstition and this finally led to its defeat. In his view, this is due to the fact that whilst Moses used the prophecy as a means of morally inciting his people, but never confused the laws of the Hebrew theocracy with the eternal laws of nature, the priests that followed him interpreted the "laws of right conduct" as "laws of nature". Thus whereas Moses always showed that he was aware of the epistemological limits of prophetic foundation in the way he organised its constitution, i.e. by separating the powers of political authority, whom he charged

\footnotetext{
152 Suggestions on the similarities between Spinoza's and Foucault's thinking can again be found in Hippler 2000. In particular, though, it would be helpful to examine this passage in light of Foucault's idea of biopower - a task that to my knowledge has not yet been done.
} 
with administering the laws, from those of the priestly caste, charged with interpreting them, the priest abused of their authorities and claimed the right to interpret and enforce the laws directly (Rosenthal 1997: 259).

In fact, as we have seen, the role of prophecy was that of an exemplar, i.e. of a 'universal idea' that serves to mediate between subjective and objective judgements. Its aim is to teach knowledge about the right conduct, not to assert the truth about nature itself. When the beings of imagination are taken as true laws of nature, according to Spinoza, they turn into superstition. The epistemological and practical status of an exemplar is that of a human construct that serves to compare things and their relative values and to promote emulation, but although they claim to represent the ideal or model of all things of a certain kind, they might in fact represent only a particular image or series of images blurred together. There is no guarantee that they constitute an adequate knowledge.

Therefore to take them as bearers of an absolute truth such as that entailed, according to Spinoza, by the knowledge of the laws of nature is to fall into superstition. Political myths must be recognised in their plurality, the plurality, in Spinoza's terms, that derives from the fact that the universality of exemplars of human nature is the universality of what we are accustomed to feign. If we fail to recognise this, and take political myths as laws of nature, then they tum into superstition.

Thus, in Spinoza's analysis of the Hebrews' history we find the basis for a whole theory of political myth. In his view, even if imagination is not an adequate kind of knowledge, such as that that can be reached by the intellect, it is on the other hand not necessarily false: it turns into falsehood, or superstition, only when it is taken beyond its limits. On the other hand, as we have seen, according to Spinoza, imagination, as a set of bodily determined ideas, is necessarily passive. In his view, it is only at the level of intellectual knowledge that autonomy, and thus real morality, can be reached.

Spinoza had a stoic view of morality and he therefore identified morality with rationality. All the same, as we will see, it is possible to question such a completely passive view of imagination. As Castoriadis has pointed out, together with a repetitive, bodily and socially determined imagination, there is also a radical or primary imagination that explains the possibility, even within a disciplinary 
society, of a radical political imaginary (Castoriadis 1975). The next step consists in drawing some conclusions from the above discussion of the main theories of political myth, by spelling out what a political myth is and the place that it occupies within the social imaginary. 


\section{POLITICAL MYTH, IDEOLOGY AND UTOPIA}

Following the above discussion of the classical theories of political myth we can now attempt to draw some conclusions as to what a political myth is and how it works within the social-historical. In the first place, all the authors we have been analysing stress the narrative dimension of myth. Cassirer stresses its being a narrative that by connecting past, present and future events posits itself as prophetic: the "myth of the twentieth century" is the myth of a superior race, the Aryan one, which, precisely on the basis of the narrative of its glorious origins, is presented as deemed to rule the world. Sorel also points to the narrative dimension of political myth: it is thanks to this dimension that people involved in big social movements can represent their upcoming action as part of a sequence of events that assures the triumph of their cause. Finally Spinoza too, who deals with political myth using the Jewish prophecy as an exemplar, stresses the narrative dimension that is implicit in the idea of "chosenness", i.e. in the story of the covenant between God and the Hebrews that is the foundation of Jewish theocracy. In this latter case we have a narrative dimension that encompasses past, present and future; the biblical prophecy looks at the past, since the aim of this prophecy is to recall the terms of the Covenant with God, and only on this basis it looks at the future and can predict the salvation of all peoples on earth through the "elected people", Israel. ${ }^{153}$

If all these authors point to the narrative dimension they also stress that there is something more at stake in a political myth. For instance, they all make reference to "prophecy", however differently understood: as foreseeing the future (Cassirer), as prevision of catastrophe (Sorel) or as a reminder of a past covenant (Spinoza). In other words, they all stressed that the narrative that constitutes a political myth also grounds - in the sense of begründen - the conditions in which the

${ }^{153}$ See for instance Jeremy 31,31 . 
human beings that believe in these myths are. Following Blumenberg, we have called this dimension Bedeutsamkeit, significance. Myth is a narrative that answers a need for significance.

The reference to the idea of "prophecy" should not however be misleading. If it is true that political myths are in a sense prophecy, it must also be added that they can be secular prophecies. Myth, we have seen, does not coincide with religion: significant is not simply that which possesses a meaning, but neither is it necessarily that which explains the meaning of life in general: something that is significant is something that situates itself between the two extremes of a simple meaning and the meaning of life and death.

This also clarifies the particularistic nature of myth and thus the reason why all these authors have dealt with singular political myths. What makes a political myth out of a simple narrative is the fact that the working on this narrative can in a certain context and for certain subjects come to coagulate and produce significance. Significance is thus always particularistic in the sense that what is significant for me here and now is not necessarily so in another context. At the same time the sphere of significance always refers to some possibility that what is significant for me here and now can also be recognised as significant by somebody else sharing the same conditions.

Spinoza points to this when he states that prophecy conveys exemplars of human nature. As we have seen, though, these latter are "universal ideas", i.e. they are not necessarily adequate ideas, since the universality at stake here is that of a "being of imagination" and, therefore, the simple universality of "what we are accustomed to feign". In other words it is not an absolute universal, but a relative one, and precisely a universal relative to the conditions in which these beings of the imagination are created.

This leads us to a crucial point. Political myths are always told from the standpoint of the present (Tudor 1972), and it is precisely for this reason that political myths are best defined in terms of a continual process of "working on myth": it is in light of the continual change in the present conditions that human beings are impelled to go back to their political myths, revise them in the light of the new needs and exigencies through their reception or, when this is not possible, dismiss them. 
Thus, to sum up, a political myth can be defined as the working on a common narrative by which the members of a social group (or society) make significance ${ }^{154}$ of their political experience and deeds. Thus what makes out of a simple narrative a political myth is not its content or its claim to truth (Lincoln 1989, Flood 1996), but rather the fact that this narrative creates significance, that it is shared by a group and that it affects the specifically political conditions in which this group operates.

The working of political myth unfolds thus in a dimension, that of the articulation and creation of significance (Bedeutsamkeit), that escapes any sharp contraposition between cognitive, practical and aesthetical spheres. A political myth can have at the same time a cognitive, practical and an aesthetical dimension, without it being possible to clearly distinguish between them in practice.

As Flood has also pointed out, political myths provide fundamental cognitive schemata for mapping the social world: it is by reducing the complexity of social life to the relative simplicity of its narrative plot, that a comprehension of the multifaceted character of experience is possible (Flood 1996). This, in its turn, points to the practical dimension of myth, as it has been underlined by Sorel: people involved in social action need to represent their upcoming action in the form of a narrative or sequence of events that assures the triumph or their cause. As we have seen, a narrative of events does not simply imply a temporal sequence of what comes into being, but also a configurational dimension, or a plot, which construes a significant whole out of scattered events. This leads to the aesthetical dimension myth or, as Tudor has put it, to the fact that political myths are narratives of events cast in a dramatic form (Tudor 1972). It is in the articulation of a drama that the pathos of political myth emerges (Lincoln 1989). This, though, cannot be separated from the other dimensions: thinking too, not only acting, can have its pathos.

Thus, going back to our previous examples, one can conclude that the myth of the Aryan race, the general strike and the Jewish prophecy, they all are political myths because they are all shared narratives that answer a need for significance, and they are political because the significance that is here at stake is that of political conditions and actions.

${ }^{154}$ To "make significance" does not simply mean to "make sense", but must be understood in the sense elucidated in Chapter 6. 
This does not mean that a myth can only be political if its content is political. According to Tudor, on the contrary, what renders specifically political a myth is precisely its subject matter. As we read in his Political myth, just as nature myths deal with natural phenomena and religious myths deal with gods and their worship, so political myth deals with politics (Tudor 1972: 17). As a consequence, according to this view, a political myth is thus "one which tells the story of a political society" (Tudor 1972: 138).

Even admitting that it would be possible to stretch the definition of society so as to encompass all those groups that produced such myths as the proletarian revolution or the Christian millennium that Tudor himself recognises as truly political, the problem that emerges within this view is how to determine the contours of a political subject. Thus, for example, the Christian myth of the apocalypse to which Tudor himself devotes great attention was not political per se. There is nothing specifically political in the claim that the world is transitory, that it was created by God and will in the fullest of time be destroyed. And in fact such an idea has not generated political myth at all times and epochs. It is only when inserted in particular contexts that they generate powerful political myths - the accurate analysis by Tudor of the myth of the millennium being a case in point.

Thus what renders specifically political a myth is not an already political content of the story it tells, but rather the fact that the story it tells comes to "make significance" for a certain social group or society of the specifically political conditions, where by political conditions I mean the conditions concerning the struggle for the distribution of power and resources that can, as last resort, have recourse to physical force. ${ }^{155}$

It becomes clear here that in order to catch the specifically political connotation of a myth one must look at the whole "working on myth". As more recent theories of political myth such as that elaborated by Flood have pointed out, in dealing with political myth it is not only at the production of myth that we must look, but also, and foremost, at its reception (Flood 1996: 7; III; IV). It is the way in which a story works within a given context, the way in which it is received, i.e. whether it

135 This is quite a widespread definition of politics. See, in particular, Weber's Politik als Beruf (Weber $1919 \mathrm{~b}$ ) and the beginning of the fourth book of his Wirtschaft und Gesellschaft (Weber 1922). As it will emerge particularly in Part IV, precisely by analysing the working of political myth one is however led to rethink this definition of politics. 
can or cannot make significance and then affect the political conditions that determines whether it is a political myth or not. ${ }^{156}$

Political myths are not, to use Gramsci's expression, "cose di carte". If we want to reconstruct the working of a political myth, it is not under the dust of our libraries that we have to look. The working of a political myth cannot be perceived by simply looking at the stories that are deposited in books and archives. The working on myth is a process that can take place in most different settings: speeches, icons, arts, both visual and not, rituals and almost all other kind of social practices.

Indeed, the possible sites for the working of political myth can hardly be enumerated. ${ }^{157}$ We can only point here to the pervasiveness of the working on myth. All activities and practises can become vehicles of political myths as far as they can incarnate a narrative dimension that encounters the need for Bedeutsamkeit. Any kind of social activity can host the working on those particular kinds of narratives that Blumenberg called "mythologems" in order to stress the fact that it is implicit in the concept of myth in general and, we can add, of political myth in particular, that there can be variants of it.

Myth thus can be learned either as stories apprehended once and for all, but also, and more often, through a more or less conscious cumulative exposure. This also elucidates the "condensational power" of political myths, i.e. their capacity to condensate in few images or "icons" (Flood 1996): by means of a synecdoche any object or gesture - a painting, an image, a song, a film, an advertisement, a gesture, etc. - can thus recall the whole working on myth that lies behind it.

This pervasiveness of myths, on the one hand, explains the difficulty of scientifically analysing them and, therefore, the relative discredit pending on this topic. It, on the other hand, has led many authors to conflate myth with other forms of human expressions and social practises. As we have seen for instance, Cassirer considered myth as a whole form of life encompassing most different phenomena such as totemism, religion, and rituals. However, a distinction must be drawn

\footnotetext{
${ }^{156}$ Tudor also seems to get close to arguing this when he states that "a myth is always told from the standpoint of the present" and this carries the implications that as the circumstances in which human beings find themselves change so they reconstruct their myth (Tudor 1972: 21, 125), but he does not finally include this feature in his definition of political myth. This perhaps depends on the fact that he conceived his Political Myth more as an introduction to the different approaches to political myth rather that as a systematic attempt to construct a theory of political myth.

${ }^{157}$ Some suggestions on the possible sites for the working of myth in contemporary societies can be found in Chapter 12.
} 
between what is a political myth and what can be the site for the working of a political myth.

In the first place, as we have seen, one must analytically distinguish between political myths and rituals. In everyday life, they are often associated since it is also through rituals that the working on political myth can take place. This does not only hold true for the so-called "primitive societies" or "forms of life"- to which the so-called ritualistic theory of myth devoted most of its attention (Tudor 1972: I, IV). For instance, an imporant body of rituals such as national festivals, commemorations of the crucial events of the national history, etc. accompany most national foundational myths. Most national days, from the American $4^{\text {th }}$ of July to the French $14^{\text {th }}$ of July, are examples of political rituals that are connected with political myths such as the American myth of the Independence and the myth of the French revolution. ${ }^{158}$

But as Tudor observes by criticising the ritualistic theories of myth, not all political myths are accompanied by any significant body of rituals (for example the myth of the Norman Yoke), as well as many political rituals, such as inauguration ceremonies, are not directly connected with any myth (Tudor 1972: 30). The point to be stressed here is that, as we have seen earlier on, myth and rituals can work within the social historical through two different modalities. The "ritual" expresses itself through fixed rules and is effective only as far as these rules are kept unchanged. On the contrary a myth, and in particular a political myth, expresses itself through variants; if a political myth is always told from the standpoint of the present and it in the present political conditions that it must provide significance, than it follows that only in so far as it is possible to go back to it and transform it according to the changing circumstances and needs it can be effective. In the last analysis, political rituals must remain unchanged in order to promote social cohesion, whereas political myths, having to begrüinden always-changing present conditions, must be open to change in order to promote the same purpose.

Thus, for example, whereas the ritual celebration of the $25^{\text {th }}$ of April has remained fundamentally unchanged, the corresponding myth of the Italian Resistenza against Nazism has changed considerably in the last 50 years (Pavone 1995, Paggi 1999, Stråth 2000). The working around the narrative of the Resistenza has indeed

\footnotetext{
${ }^{158}$ On the link between national days celebrations and political myth, see for instance Thorsen 2000 .
} 
coagulated and provided significance to very different actors and in very different contexts. As Pavone observes, the problem in dealing with the Resistenza as an historian is that the Resistenza as an historical problem is quite often intermingled with the working around the Resistenza as a "civic problem" in general but also as a "myth" in particular (Pavone 1995:185). ${ }^{159}$ The narrative of the Resistenza has not only worked as narrative legitimating the new Repubblica Italiana - as it is signalled by the widespread formula "Repubblica nata dalla resistenza", but it has also worked as a narrative that, by operating at the crossroads between memory of the past and expectations for the future as embodied by certain of human exemplars, provided significance to different generations and in very different contexts. ${ }^{160}$

Political myths must always be up-to-date, otherwise they cease to be political myths and become something else. Political myths are not simple abstract models to which to compare existing political conditions. They can also be this, but they are never only this. They are always at the same time determinations to act: they are narratives that precisely because they answer a need for significance prompt people to action. Political myths therefore cannot be falsified: the fact that what they contain has not or will not be realised does not diminish their power. As Sorel pointed out, political myths must not be judged as astrological almanacs, but rather as a means for acting on the present.

This does not mean that they are impermeable to critical discussion. The fact that they cannot be falsified by what actually happens does not mean that they cannot be rationally discussed. What Sorel, Spinoza and Cassirer do in their theories is precisely to critically discuss them. The point is rather that the way in which the discussion must be done is not that of their "real or unreal content", but rather that of their appropriateness as means for acting on the present: the moral of story they tell, i.e. the values that they purport, on the one hand, and their capacity to create significance in those particular conditions, on the other.

This, of course, holds for the pure ideal-typical political myths. In fact, as we shall see, the political myths we are more familiar with are often intermingled

${ }^{159}$ On the difference between mythical and historical narratives, see Chapter 10.

160 As Pavone observes, the study of the myth of the Resistenza cannot but start from the study of the innumerable amounts of tales, novels, films, documentaries, monuments, etc. which in the last fifty years have been the privileged sites for the working on the myth of the Resistenza (Pavone 1995). This does not mean that there is one single myth of the Resistenza and even less that the narrative of the Resistenza always 
with other kinds of discourses. This is the consequence of the pervasiveness of political myth. The myth of the Aryan race is, for instance, constructed on the basis of scientific findings, which clearly bring to the ground other kinds of considerations that call for a different method of judgement: the biological finding upon which it rests and its mythical side must be judged with different tools, even if in reality the two kinds of discourse are intermingled. Thus even if there is no dichotomy of myth versus science such as that from which we departed in this work, there still remains a difference between the two that cannot but bring in different kinds of considerations. As Spinoza pointed out, the risk, when the two orders of considerations are not kept separate, is to fall into superstition: this for instance happened when the moral message encompassed in the Jewish prophecy of Israel's election was taken as a law of nature. And this is what he fears would happen if his contemporaries, the Dutch Calvinists, interpret the myth of their "chosenness" in those terms.

Analogously, in many national myths, we have a melange of mythical and other elements. Clearly the two bring different sorts of consideration to the ground and call for different tools of evaluation. ${ }^{161}$ The Italian Resistenza or the French Revolution are neither pure myths nor pure historical events. They can work as both, but we must accordingly analyse them with the most appropriate tools. As we shall see, even if there rarely are pure historians, what historians do, and what we expect them to do, when they present their historical narratives, is to refer to a method that asks them to base their narratives on documents and testimonies, i.e. on other (in principle revisable) narratives. The ideal-typical myth-maker, let us submit for the moment that there is a pure one, does not refer to other evidences: his capacity to address the present conditions is a sufficient condition. The myth-maker wants to incite to action, not (only) to accurately reconstruct the past. If he looks at the past he does it with the immediate intent of inciting to future action.

Thus even if some historical narratives, such as the French revolution or the Italian Resistenza, work and have been working in certain contexts as political myths, there are plenty of historical narratives that are not political myths - we do not even need to make single examples: just take all the narratives that do not provide significance for certain subjects in certain moments. Furthermore, there are

works as a myth: as Paggi points out, in order to estabilish whether this narrative is working as a myth or not, one has to start from specific regional and local contexts (Paggi 1999).

${ }^{161}$ On the relationship between myth and historical narratives see Chapter 10. 
also political myths, such as that of the general strike, that - as Sorel points out - are all constructed in a future dimension: and this is sufficient, at the ideal-typical level, for keeping historical narratives and mythical one separate.

Not even all the founding-narratives are political myth. What decides between different and altemative narratives to become political myths or not is their capacity to answer a need for significance, and not all the founding narratives are able to coagulate it in certain conditions and contexts. Let me illustrate the point with one example. The existence of the Sicilian "Assemblea Regionale", an organ that was given to the Sicilians in order to satisfy the constant striving for independence of the island, has at least two founding narratives. One tells that the assembly was instituted in 1946 together with the concession to the island of a "statuto speciale" within the newly constituted Italian Republic. Another one calls it the "Sicilian parliament" and states that the parliament was first instituted by Frederick II in the Middle Ages. According to this latter founding narrative, the Sicilian parliament was one of the first European parliaments, much older than the Italian one.

Now, whereas the first narrative is certainly an important founding narrative, it cannot, in the present conditions, aspire to have the same mythical impact as has the other narrative. The founding narrative must be significant for a certain group of people in order to become their myth. In fact, the second narrative only can provide significance to the present political conditions and actions of the Sicilians - or at least most of them, whereas the first narrative cannot, in the present conditions.

It is not a matter of objective interests at stake: the question is not which narrative can be better used in order to uphold a certain material interests. Not all the possible narratives that suit those interests could have aspired to the role of political myths. This explains why a political myth cannot simply be fabricated around a table. Political myths must insert themselves within certain given conditions and which are most of the time intermingled with other kind of discourses, but they must not be conflated with them.

One of the reasons why political myth was given so little attention in theoretical debate is that it has been often deployed together with other and more familiar kinds of discourse. They somehow tend to get lost under them. And the reason why this happens is easy to see; we almost never see a pure myth-maker at 
work: his mythical account will inevitably deal with matters touched upon also by writers, philosophers, historians and scientists and it is most often only to these that the critical discussion appoints itself. One of the concept with which political myth is most often conflated is ideology. ${ }^{162}$ It can be argued, however, that notwithstanding the important interconnections between the two, political myth and ideology must be kept analytically separated and used to address only partially overlapping social phenomena.

A classical example of the attempt to deal with political myths under the heading of "ideology" is Raymond Aron's L'opium des intellectuals (1955). Written in the fifties in order to analyse the reasons for the uncritical attitude of the French communist towards the politics of the Soviet Union, the book had a clear polemical intent. This latter is patent from its very title: with "The opium of intellectuals" Aron reverses Marx's criticism of the religious alienation against Marxism itself, or better - against the French Marxist militants of the beginning of the fifties, in order to point out that Marxism, far from leading to liberation from alienation, had itself turned into a form of religious alienation.

According to Aron, the attitude of the French communists toward Marxism could only be explained in terms of the power exercised by Marxism as a philosophy of history that provides a universal and all encompassing truth (Aron 1955, V) and that, thanks to its mobilising impact, can raise passions worthy of crusaders (Aron 1955: III): "The doctrine provides true Communists with a global interpretation of the universe; it instils sentiments akin to those of crusaders of all ages; it fixes the hierarchy of values and estabilishes the norm of good conduct" (Aron 1955, IX: 265).

This, in Aron's view, is confirmed by the expressions used by the young Marx in his description of the class struggle. These expressions would not leave any doubts over the Jewish and Christian origins of the myth of the proletariat. In Aron's analysis the myth of the proletariat reveals its religious origins because it is the story of an agent of salvation, elected as a vehicle of the redemption of humanity on the basis of its suffering. It is precisely on this structure that all kinds of Christian eschatology are based and it is from the passions instilled by eschatology that,

\footnotetext{
${ }^{162}$ As we have seen, Flood 1996 is a typical example.
} 
according to Aron, the annihilation of the critical capacity of the French communists would derive (Aron 1955, III).

In particular, this loss of critical attitude is evident in people's tendency to impose everywhere the same eschatological scheme and thereby overlook the complexity of reality and the radical diversity of historical circumstances. This, in Aron's view, is particularly evident in the working of three of the political myths that he analyses: the myth of the left, the myth of the revolution and the myth of the proletariat. All these myths, according to Aron would exhibit their correspondence to the eschatology depicted above and it is to the latter that he attributes the mobilizing and totalizing power of those political myths (Aron 1955, I-III).

There are therefore, according to Aron, three characteristics of "political myths" understood as "ideologies", i.e. of the opium of the people: 1 . They are systems of ideas that reveal a universal truth providing a meaning to everything, and are therefore totalizing; 2 . They mobilize passions, and 3 . They are utopian in as far as they neglect the complexity of reality and of the specific historical circumstances. On this basis, Aron was also predicting the advent of "the end of ideologies": in the aftermath of the Second World War, after the defeat of fascism and the affirmation of democracy, the longing for ideology was in his view deemed to be superseded by a careful pragmatism more inclined to look at the specificity of different contexts. ${ }^{163}$

There is however a double problem with this treatment of political myth. Firstly, from the point of view of a theory of political myth it is subjected to the same kind of criticism that can be raised against any attempt to unify myth and religion under common headings such as Cassirer's "mythical consciousness" or "the opium of intellectuals". I will not repeat here previous considerations, but simply observe that if political myths are characterised as narratives providing significance that, by locating human action within a coherent narrative, prompt people to act, this is not a sufficient condition for assimilating them to religion. If it is true, as Sorel and more recently Tudor has observed, that Marxism, when inserted in certain contexts has also worked as a political myth, this is not a sufficient condition for assimilating it to religion, on the one hand, or to ideology, on the other (Tudor 1996: 126).

Secondly, it can be argued that this view is constructed in such a way that is destined to fall victim to its own tools: the criticism of ideologies as the opium of the

${ }^{163}$ Among the supporters of the "end of ideologies" thesis, see also Bell 1960 and Shils 1958. 
masses that was used by Aron against Marx who first formulated it can well be used against Aron himself. This becomes evident at the end of the book when Aron is confronted with the objection that democracy and nationalism are also ideologies since they have also been able to instil ardour not less passionate than that instilled by the myth of a society without classes (Aron 1955, IX). Aron's reply to this possible objection consists in vindicating the uniqueness of communism as ideology precisely on the basis of its prophetic structure.

Let us now look more closely at what, according to Aron, this means, i.e. at what precisely characterises ideology understood as prophecy. For Aron communism, like all kinds of prophecies, is constructed around three elements: condemnation of the status quo, the depiction of what should be, and (possibly) the individuation of a subject in charge of leading from the present to a future condition (Aron 1955, IX). But in this sense, the "end of ideologies" thesis is itself an ideology: clearly, it entails a condemnation of the age of ideologies, as well as the prophetic assertion of its immanent end and individuation of a subject, the disengaged social theorist, that can, if not lead this transition, at least prepare its way.

The problem is that, once entered into the polemical use of the concept of ideology, it becomes impossible to call oneself out of it: it triggers a vicious circle. The dichotomy of "ideological versus real" upon which this use ultimately rests can always be reverted against those who employ it. Aron remains victim of his own polemical usage of the concept of ideology. However, as many authors have pointed out, together with this polemical use of the term ideology, there is another, more neutral one. ${ }^{164}$ As has been stressed from different sides, notwithstanding the multifaceted varieties of the possible uses of the term ideology - Eagleton counts at least 15 of them (Eagleton 1991) - they can all be subsumed under two types.

The first kind in use is more restricted and might be defined as the negative, or at least polemical, view of ideology: ideology, in this view, fundamentally refers to some kind of false consciousness or disguise through a fictitious covering of the true reality of facts. The hallmark of this use, as we have seen in Aron's theory, is the contrast between what is "ideological" and what is "real". This use of the term was first inaugurated by Napoleon who with this term intended to criticise the abstract

${ }^{164}$ See for instance Dubois 2001, Freeden 2001, Stoppino 1983, Thompson 2001. 
idealism of "les idéologues" as contrasted with the reality of facts and pragmatism of political affairs (Dierse 1976).

As well known, the term was most influentially used in this sense by Marx and Engels, who deeply contributed to physiognomy of polemical use of the concept. ${ }^{165}$ Initially Marx and Engels used the term in their criticism towards "The German Ideology", i.e. the fundamentally illusory attempts of the Young Hegelians to modify the society they lived in through the sheer criticism of ideas (Marx and Engels 1845-6).

"The entire body of German philosophical criticism, so they wrote, from Strauss to Stirner is confined to criticism of religious conceptions [...]. Their advance consisted in subsuming the allegedly dominant metaphysical, political, juridical moral and other conceptions under the class of religious or theological conception [...] The Young Hegelian ideologists, in spite of their allegedly "world-shattering" statement, are the staunchest conservatives. The most recent of them have found the correct expression for their activity when they declare they are only fighting against "phrases". They forget however, that to these phrases they themselves are opposing only other phrases and that they are in no way combating the real existing world when they are merely combating the phrases of this world [...] It has not occurred to any of these philosophers to inquire into the connection of the German philosophy with German reality, the relation of their criticism to their own material surroundings" (Marx, Engels 1845-6: 148, emphasis mine).

The polemic is here conducted against a topos of the German literature, whose origins go as far back as the epoch of the French revolution, and according to which Germany, economically and politically backward in comparison with France, could only operate in thought, i.e. through the philosophical criticism, the same revolution that France has operated in action. The criticism of this "ideological view" is conducted through a continual contrast between the level of ideas and that of reality, and, in this sense, early Marx and Engels's usage of the term is closely related to Napoleon's criticism of "les idéologues".

Since his Contribution to the Critique of Hegel's Philosophy of Right, Marx had already been vindicating the need for a "material basis of the revolution" against the view advanced by the "German ideologists" (Marx 1844). Against the illusions of

\footnotetext{
${ }^{165}$ According to Mannheim, the anticipation of this concept of jdeology goes as far back as Francis Bacon's critique of the idola or prejudices (Mannheim 1936: 55). Nevertheless, it is without doubt only by the time of the French revolution that the term ideology started to be used in the common sense of the term.
} 
those ideologist, who could not but think of revolutions in a glass of water, Marx had already since 1843 been emphasising that the arm of criticism cannot replace the criticism of arms (Marx 1844). Two years after, in The German Ideology (1845-6) the dichotomy "ideological" versus "real" takes the form of a contrast between "idealism" and what is now called the "materialistic conception of history". Its method is very efficiently synthesised: "the premises from which we begin are not arbitrary ones, not dogmas, but real premises from which abstraction can only be made in imagination. They are the real individuals, their activity and the material conditions under which they live, both those which they find already existing and those produced by their activity. These premises can thus be verified in a purely empirical way" (Marx Engels 1845-6, emphasis mine).

With historical materialism, particularly in its successive elaborations when the reference to the material conditions of existence was to take the form of a detailed analysis of the economic modes and relations of production, the term "ideology" tends to widen so as to cover the whole complex of social historical phenomena: not only religious and philosophical ones, but also political and juridical, in a word all that which is super-structural in respect to the economic structure, i.e. the real material conditions for the reproduction of life.

As has been observed from various sides, Marx and Engels's analysis of ideology is a permanent acquisition: it contributed to rooting the evanescent world of ideas in the solid ground of the social structure, i.e. to show the necessity of ideological constructions, and if the Marxist view of ideology is no longer hegemonic in academic debate this is to a great extent due to the fact that it became a sort of standard intellectual equipment (Geertz 1964).

On the other hand, the questions raised by a theory of political myth do not coincide with those faced by Marx and Engels: what is of interest here is not to raise the issue of why ideological constructions are necessary or to what kind of mode of production they correspond, but rather why human beings, among the different human constructions of meaning, also need to make recourse to narratives that respond to need for significance. Conflating myth and ideology can therefore only be impoverishing.

In particular, from the point of view of a theory of political myth, the problem is that by contrasting both political myth and ideology with the "real 
material conditions of existence" not only does it become difficult to draw any distinction between myth and ideology but, in particular, there is the risk of falling once more into the Enlightenment's dichotomy of "myth versus reality". Marx's analysis of the uses made by the French revolutionaries of the myth of the Roman Republic is a good example of this risk.

In the Preface to the second edition of The Eighteenth Brumaire of Louis Bonaparte, Marx states that his intention in this work was "to demonstrate how the class struggle in France created circumstances and relationships that made it possible for a grotesque mediocrity to play a hero's part" (Marx 1852: 395). He began his essay by observing that human beings do not make their history under circumstances chosen by themselves, but rather under circumstances that they found as already given and transmitted from the past; among those circumstances is the tradition of the dead generations "that weight like a nightmare on the brain of the living" (Marx 1852: 398). Therefore, even when human beings seem engaged in creating something entirely new,

"[...] precisely in such epochs of revolutionary crises they anxiously conjure up the spirits of the past to their service, and borrow from them names, battle slogans and costumes in order to present the new scene of world history in this time-honoured disguise and this borrowed language. Thus Luther donned the mask of the Apostle Paul, the Revolution of the 1789 to 1814 draped itself alternatively as the Roman Republic and the Roman Empire, and the Revolution of 1848 knew nothing better to do than to parody, in tum 1789 and the revolutionary tradition of 1793 to 1795" (Marx 1852: 399).

Marx is here referring to one narrative, that of the Roman republic, that is likely to have worked to a great extent as political myth for the French revolutionaries. However, Marx is interested here in the phenomenon of ideology and thus states that the French revolutionaries needed to perform the task of their time, releasing and setting up a modern bourgeois society, in Roman costumes and with Roman phrases because, unheroic as bourgeois society is, it had need of heroism, sacrifice, and civil war to comes into being: "in the classical austere traditions of the Roman republic its gladiators found the ideals and the art forms, the self-deceptions that they needed in order to conceal from themselves the bourgeois limitations of the content of their struggles and to keep their passions at the height of the great historical tragedy" (Marx 1852: 399: emphasis added). Similarly, Marx 
further observes, at another stage of development, a century earlier, Cromwell and the English people made their bourgeois revolution by borrowing "speech, passions and illusions" from the Old Testament: "only when the real aim had been achieved, when the bourgeois transformation of English society had been accomplished, Locke supplanted Habakkuk" (Marx 1852: 399). Ideology, thus, is a self-deception, but a self-deception that is necessary.

Moving from this analysis, the only aspect that could be said to unite political myths and ideology is their being a self-deception, that, however necessary, is meant to present particular interests, in this case those of the bourgeoisie, in the form of universally valid and recognised principles such as those embodied by the Roman tradition or the Old Testament. Thus, when analysing the events of the $18^{\text {th }}$ Brumaire, Marx constructs his account through a long chain of conceptual oppositions: "Roman phrases"166 versus their "real task", "the antediluvian Colossi and the resurrected Romans (from Brutus and Gracchi to the senators and Caesar)" versus "the sober reality of bourgeois society and its true interpreters such as its Says, Constants, Guizots and its real military leaders", " the heroic self-deceptions" versus "the bourgeois limitations of their struggle", " the magnification of their tasks in imagination" versus "the finding of a solution in reality" (Marx 1852: 399-401; emphasis added). Phrases versus reality, imagination versus reality, the result of all these conceptual oppositions is that political myths and ideology are necessarily presented as deceptions. But the problem raised by a theory of political myth is why people needed to represent their action precisely in this way. Why did the French revolutionaries needed to perform the task of their epoch in Roman customs, and not Greek or Turkish? Why could only the narrative of the Roman Republic make significance for them?

Marx's theory does not aim to deal with these questions. Thus, for instance, when he moves onto analysing proletarian revolutions, to the need for "selfdeceptions" of the French Revolutionaries, Marx counterpoises the proletarian revolutions: "the social revolution, he argues, cannot draw its poetry from the past, but only from the future; and therefore cannot begin before it has stripped all superstition in regard to the past"; thus, as he concludes, "there [in bourgeois

\footnotetext{
${ }^{166}$ Marx used the same contraposition between "phrases" versus "reality" in order to criticize the attempt of the German ideologists to make a revolution by simply criticizing ideas. As we have seen, for Marx and Engels these were sheer revolutions in a glass of water.
} 
revolutions] the phrase went beyond the content, here [in the proletarian revolution] the content goes beyond the phrase" (Marx 1852: 400). Thus, the proletariat, which will only be looking at the future, will not need the self-deception of wearing Roman or other costumes for their revolution.

On the other hand, this does not say much about the proletariat's need for political myth. Marx was right in saying that the proletarian revolution could only draw its poetry from the future - and Sorel would certainly agree with him on this point. But this does not mean that they do not need any form of narrative that provides significance. Therefore the concept of ideology understood as a more or less necessary false consciousness is of limited use for a theory of political myth.

All the same, one could assume that by elaborating a different view of ideology, the concept of political myth may still be treated together with that of ideology. For instance, as has been noted, in Marx there are signs of a passage from a polemical, and thus particular, view of ideology to what has been called a "total view of ideology". Karl Mannheim, who explicitly proposed to adopt a neutral concept of ideology, has strongly emphasised this point. ${ }^{167}$ According to Mannheim, whereas the particular conception of ideology, by presenting ideas as the more or less conscious disguise of the real nature of a situation, makes specific assumptions as to the mystifying relationship between the two, what he calls the "total conception of ideology" simply presupposes that there is a correspondence between a given social situation and a given perspective or point of view (Mannheim 1936: 51). In this second sense, according to Mannheim, we refer to the ideology of an age or a concrete social historical group, e.g. of a class, when we are concerned with the characteristics and composition of the total structure of the mind of this epoch or of this group (Mannheim 1936: 49-50).

Thus, whereas the first conception of ideology focusing on the errors of the individuals is the field of psychology, the second one is the field of what he calls a "sociology of knowledge", i.e. a discipline concerned with ideology in the sense of interwoven systems of thought and modes of experience that are conditioned by the social circumstances shared by groups of individuals. Marx, by having traced ideology back to its social roots, has taken an important step from the particular to the total concept of ideology, but by remaining attached to the idea of ideology as

${ }^{167}$ See Dubois 2001, Freeden 2001, Stoppino 1983, Thompson 2001. 
false consciousness he was still with one foot in the particular view of ideology (Mannheim 1936, II, ch.3).

To assume a neutral concept of ideology, as first inaugurated by Mannheim, is thus crucial in order to discuss its relationship with political myth. This does not mean that by using a neutral definition one aims at transcending the historically situated character of any sociology of knowledge: the intellectual is always himself within ideology and never a free-floating being transcending the inevitable perspectiveness of any enquiry. ${ }^{168}$ The performative impact of any work in the social sciences is always such that absolute neutrality in this sense is impossible.

To assume a neutral meaning, however, does not mean this. It rather simply means not making any strong ontological assumption over the nature of the relationship between ideology and the social historical. Following Mannheim's insights, this simply means to assume that there is a strict relationship between the two, without, however, entering into any substantive characterisation of their relationship. Indeed, it is to such a definition of ideology that contemporary theorists of political myth have been referring (see Tudor 1972 and more recently Lincoln 1989 and Flood 1996).

According to Christopher Flood, for instance, political myth situates itself precisely between ideology thus conceived and what he calls the sacred myth, i.e. myth as it is used within religious systems. And the two definitions of ideology to which he refers are examples of the neutral meaning: ideology, he states picking up two of the most common definitions in contemporary social science, is a "belief system that explains and justifies a preferred political order for society, either existing or proposed, and offers a strategy (processes, institutional arrangements, programs) for its attainment", or otherwise stated ideology is a "set of ideas by which men posit, explain and justify ends and means of organised social action, and specifically political action, irrespective of whether such action aims to preserve, amend, uproot or rebuild a given social order" (Flood 1996: 13).

\footnotetext{
${ }^{168}$ According to Freeden, Mannheim would, on the contrary, have attempted at overcoming the relativism through his own sociology of knowledge, since he would grant to the free-floating intellectuals the capacity of incorporating the perspective of different groups into a holistic relationism and, thereby, to attain a critical approximation of truth (Freeden 2001). Independently from the correctness of this interpretation, the important point to stress here is that this is not what we mean by a "neutral" type of use of the concept of ideology.
} 
The advantages in this perspective are clear. From the point of view of a theory of political myth, firstly, it does not carry with it any assumption over the reality or unreality of both ideology and political myth. Secondly, this view enables us to address one important common feature of political myth and ideology. Such definitions do not make any assumption over the nature of these beliefs: they do not limit ideology to false/true or conscious/unconscious beliefs and ideas. In other words, they do not analyse ideology from the psychological point of view, i.e. from the point of view of the single individual, and they, therefore, make no assumptions as to the degree to which these motivations must be present in the consciousness of single acting individuals. Indeed, in order to analyse the impact of a political myth or, more generally, of an ideology one cannot limit himself to the level of individual psychology (let us admit for the moment that this is possible), since it can well be the case that not all elements constituting a political myth or an ideology are present in all their parts hic et nunc in the single mind of an individual.

As Geertz noted, only the first answer provided to the question "Why do individuals need ideology?" can be psychological (Geertz 1964). A huge amount of literature drawing inspiration from Freud's discoveries would tell us that ideologies are collections of invested symbols that are needed in order to overcome the chronic misintegration of society: be it in the form of the scapegoat theory, according to which ideology is a symbolic construction that drains off emotional tension through the creation of a symbolic enemy, or any other way of overcoming the strain created by the very condition of living in a society. In any case, it is always at the psychological level that the determinant of the production of ideology is located. Again, the acquisitions in this field are enormous and permanent. But what interests here is not so much to investigate, to go back to the Marxian example, what emotional disequilibrium determined the need to invest the Roman customs of such an ideological power: the question is rather why they needed to perform their task in somebody else's customs, how this came to be shared and why they needed to do it precisely with Roman rather than with other customs.

Two qualifications must however be added to the above-mentioned definitions of ideology. The first definition of ideology as a "belief system" does not simply correspond to the second in terms of a "set of ideas" - as Flood seems to suggest (Flood 1996, I): it adds a further dimension, that of the systematic character 
of the set of ideas constituting ideology. However this holds true only for certain types of ideology, notably those to which the thesis of "the end of ideology" refers. In comparison to them, contemporary forms of ideology rather evoke the image of an archipelago in contrast to that of a continent (Boudon 1999). As R. Boudon reminds us, we have ideologies on what should be done about unemployment, educational opportunities, crime or drug addiction and on a myriad of subjects, as well as to how it should be done. But these theories are weakly related to one another. We have ceased to believe that they could be derived from an all-encompassing theory. We have all kinds of local ideologies; we no longer believe in general ideologies (Boudon 1999). In other words, ideology is much more pervasive than any other "system of beliefs".

As C. Geertz, among others, has pointed out, ideologies are mapping devices whose cognitive impact is secondary in comparison to their practical function: ideology serves to provide a map of the social reality that orients both at the cognitive as well as at the practical level (Geertz 1964). The reason why such symbolic templates are necessary is that human behaviour, in contrast to that of lower animals, is not for the most part determined by innate, physiologically determined patterns of behaviour: birds learn how to fly without wind tunnels and, whatever reaction they may have in the face of death, this is to a great extent physiologically preformed. On the contrary, the extreme generality and variability of human capacities of response mean that their patterns of their behaviour are guided predominantly by cultural rather than innate templates (Geertz 1964: 63). The toolmaking and lying animal is for Geertz, as it was for Gehlen, "an incomplete - or more accurately, self-completing animal"169: the agent of his own realisation, he creates out of his general capacity for the construction of symbolic models the specific capacity that defines him, and in particular it is through the construction of ideologies, schematic images of political order and actions, that he makes himself a (political animal (Geertz 1964: 63).

Thus, going back to the second of the above mentioned definitions of ideology proposed by Flood we can conclude that an ideology is a sets of ideas by which human beings posit, understand and justify ends and means of a more or less

\footnotetext{
${ }^{169}$ See the discussion of Gehlen's recovery of Nietzsche's definition of human beings as noch nicht festegestelle Tiere in Chapter 3.
} 
organised social action, irrespective of whether such action aims to preserve, amend, uproot or rebuild a given social order. ${ }^{170}$ The intersection-with the concept of political myth is indeed clear: a political myth also entails a set of ideas by which human beings posit and represent ends and means of social action. But not all such sets of ideas constitute a political myth. In order to constitute a political myth two further conditions must be met. This set of ideas must take the forms of a narrative, i.e. of a series of events cast in a dramatic form and precisely on the basis of this narrative form it must be able to begründen or to coagulate and reproduce significance. To put it bluntly, political myths are narratives putting a drama on stage. $^{171}$

From this point of view, political myths resemble modern utopias. Many authors have dealt with myth under the heading of utopia, by this latter meaning though a general state of the mind that is incongruous with the reality within which it occurs: a utopia is, latu sensu, the description of an unrealizable state of things. ${ }^{172}$ According to Mannheim, for instance, both myths and utopias are indeed the product of wishful thinking:

"When imagination finds no satisfaction in existing reality, it seeks refuge in wishfully constructed places and periods. Myths, fairy tales, otherwordly promises of religion, humanistic fantasies, travel romances, have always been continually changing expression of that which was lacking in actual life" (Mannheim 1936: 184).

As a consequence, according to Mannheim, the utopian mentality works in opposition to the status quo and aims at its disintegration, whereas ideology, even when it does not precisely correspond to the status quo, nevertheless tends towards its preservation because it is congruous with it: utopias are revolutionary because they tend to burst the boundaries of the existing order (Mannheim 1936: in particular 173-184).

Apart from the general problems connected with the definition of the category of "reality" that, as Mannheim himself in many places recognises is a

\footnotetext{
${ }^{170}$ In respect of the original formulation of this definition where reference is made to ideology as a means of "positing, explaining and justifying" I have omitted the second verb, since in the most general sense of the term "to explain" this is already implicit in the verb "to justify" whereas in the strongest sense, that of a "scientific explanation this would not enable me to encompass political myth within it. Similarly, I have modified the reference to "organized social and specifically political action". The action that is promoted by apolitical myth, as well as by ideology, can in fact be more or less organized.

${ }^{1 / 1}$ Many contemporary theorists of political myth insist on this point: see Tudor 1972 and Flood 1996.
} 
definition that is always historically situated (Mannheim 1936: 91, 174 and ff), from our point of view the problem is the impossibility of defining political myth in relation to its congruence/incongruence with social reality thus conceived: indeed, not all political myths are revolutionary, in as much as not all ideologies, at least as we have defined them, are conservative. Moving from such a characterisation of the "utopian mentality", it becomes impossible to grasp the difference between political myth, utopia and ideology.

However, if by "utopia" we rather understand strictu sensu that literary genus that was inaugurated by Thomas More's Utopia, then similarities and differences between this genus and political myth come to light. Indeed, the literary genus that goes from More to the negative utopia of Orwell's 1984 through authors such as Campanella, Fontenelle and Fourier, is precisely characterised by the narrative form in which it casts the description, the ou-topos - the place that is nowhere, according to the fortunate expression coined by More. Typically, the description of the perfect or ideal society takes the form of narration by a traveller of his discovery of this ou-topos (no-place) - or perhaps eu-topos (good place), ${ }^{173}$ which is classically an island or at least a territory repaired from other societies and whose organisation, customs and habits are described up to the most apparently insignificant details of everyday life.

But it is not just the narrative form that unites political myth and utopias. As has been observed, modern utopias were forms of radical secularised theodicy: they address the problem of the existence of evil, but, in contrast to Christian theodicy, they move from the assumption that any form of evil is resolvable in this world through a radical reorganisation of social life (Moneti 1992: 406). Therefore, independently from the relationship with reality, we can say that what characterises utopias in this sense is rather their "regulative function". By regulative I mean, following Kant, the capacity of ideas to serve as guiding ideals independently of their being more or less constitutive of the world of phenomena. ${ }^{174}$

\footnotetext{
${ }^{172}$ On utopia, particularly from the point of view of the social utopias, see Maffey 1983 and Cazes 2001.

${ }^{173}$ As Maffey reminds us, the problem of the meaning of the neologism coined by More was a big problem for the interpreters of More since the very first years of its publication: U-topia can mean Eu-topia (the good place) or the Ou-topia (the no-place). Indeed, the same Thomas More seems to allow both interpretation (Maffey 1989: 1215)

${ }^{174}$ In this sense, for instance, authors from the Frankfurt School recovered, against Marx and Engels's critique of utopian socialism, the positive function of utopia: as Marcuse observed, in an age where the end of utopia is a real possibility because there seems to be no limit to technical mastery even over the laws of
} 
Political myths and utopias both have a regulative function. Despite the fact that a political myth can also be articulated in the dimension of the past, as is the case with most of the foundation myths, its function is always to address the present conditions and orientations within them. The same holds for utopias: both positive and negative utopias, independently from their being more or less "realistic", are always programs for the reform of the present. In other words, both political myths and utopias can be the sites for the working of the radical imagination. Imagination, as Castoriadis points out, creates "ex nihilo" - not in nihilo or cum nihilo, as romantic theories of imagination tend to assume. As we will see, this means that, together with the repetitive and passively conceived imagination, such as it has been depicted by Spinoza, there is also a creative or radical imagination: it is from this creative side of imagination that the critical impact, exercised by both utopias and political myth, stems. However, political myths are not necessarily the site for the working of critical imagination: they can, and perhaps most often, do the opposite. Despite the fact that political myths, in contrast to utopias, do not always exercise such a critical function, there is always the possibility for them to do it, and in this possibility lies its regulative function.

Another difference between political myth and utopia is that, whereas utopias are radical secularised theodicy in the sense that they aim at radically extirpating evil through the construction of a perfect society, political myths do not necessarily aim at a radical solution once and for all of all the problems. Utopias are theoretical constructions that have a regulative function because they are the means for measuring the general good and bad contained in any society, whereas political myths are regulative because, as Sorel pointed out, they are direct determinations to act: it is from their capacity to put on stage a drama whose protagonists are those involved in the working of myth that provides them with a regulative function. In other words, utopias are "no-places", whereas political myths are invitations to act here and now: hic Rhodus, hic saltus.

Precisely because political myths respond to a need for significance here and now and because, in contrast to utopia, they do not necessarily aim at a definitive answer to the problem of theodicy, they must be open to the possibility of being

nature, it is necessary to go from science to utopia - and not the other way round as Engels sustained (Marcuse 1967). 
retold according to the changing circumstances. Whereas utopias can be eternal, a political myth can be old, even ancient, but never eternal. Otherwise said, political myths too address the problem of the theodicy, i.e. the problem of the congruence between good and luck, but they do not necessarily aim at resolving it once for all: rather we could say that it is precisely the impossibility of providing a definitive answer to this dilemma that fosters the need for significance and thus the continual retelling of myth.

On the contrary, when the working on myth aims at providing a definitive answer, it tends to generate closed myths, i.e. myths that tend towards the elimination of contingency. These, however, are only a particular kind of myth: among them, are quite often religious and naturalised myths. Both these latter are myths that deny their historical nature, either by invoking their sacredness or their naturality. Political myth, however, lives out of history. Thus, whereas a narrative can be utopian by nature because it violates its alleged laws, ${ }^{175}$ nothing could ever be mythical by "nature" because it is always history that nourishes the Arbeit am Mythos.

\footnotetext{
${ }^{175}$ When Marcuse announced the end of utopia he did it by pointing to the possibility that modern technique had definitely rendered the idea of a supposed "limit by nature" obsolete (Marcuse 1967). Certainly also the so-called "laws of nature" are historical, but they are historical in a different sense: they are historically determined, but they do not live out of history as political myth does.
} 


\section{MYTH AND POLITICAL IDENTITY}

Political myths are narratives that coagulate and reproduce significance. They are the working on a common narrative by which the members of a social group or society represent and posit their experience and deeds. As such they are an important part of what, following Castoriadis, can be called the social imaginary (Castoriadis 1975). Once political myths are defined in this way, the problem emerges of analysing their relationship with other kinds of narratives that also are constitutive of the social imaginary.

In particular, both myths and historical narratives are positional, that is they are told from the standpoint of the present. In other words, if the historian can also be defined as a "turned-back prophet" (Schlegel, F. 1798: Fragm. 80), in what ways does he differ from an ideal typical myth-maker? Or, otherwise put, in what ways do political myths and historical narratives respectively contribute to, or are the result of, present identities?

These are the questions addressed in the following chapters. In particular, Chapter 10 discusses the relationship between historical and mythical narratives, the extent to which they can possibly overlap, but also the reasons why they must be kept analytically distinguished.

This, in its tum, leads us to exploring the ways in which political myth relates to cultural, social and political identities. By criticising Schmitt's view of political myth as a symptom of an already constituted identity, Chapter 11 argues that the working on political myth is not just the result, but also the producer of common political identities. Furthermore, in contrast to Schmitt's usage of the term, the chapter argues for a differentiation between the different forms of identity - personal, social, cultural, political etc. - aimed at avoiding normatively problematic outcomes, such as Schmitt's conclusion 
that dictatorship is not incompatible with democracy because it is based on the "identity" between the Führer and the people.

This does not mean though to disregard the possible overlapping between different forms of identity. In particular, precisely by confronting the issue of political identity from the standpoint of the working of political myth, it will be suggested that no sharp contraposition between political and cultural identity can be drawn. If not all cultural myths are political, there is always the possibility that the working on a cultural myth, which has nothing political in se, can come to affect specifically political conditions, and thus to contribute to shaping a common political identity.

Finally, Chapter 12 advances some hypotheses on the possible sites for the working of political myths today. There are reasons to suspect that, under the contemporary conditions of a global spectacle, the working of political myth, disseminated in archipelagos of icons covertly recalling each other, becomes not only potentially global, but also less and less locatable. Thus, the hypothesis is suggested that political myths today operate through an interplay of the banal and the extraordinary, where by "banal" I etymologically mean that which has become a commonplace by virtue of its continual use within a community. 


\section{MYTH, HISTORICAL NARRATIVES AND THE SOCIAL}

IMAGINARY

According to one view, history consists of a congeries of events, individual and collective, whose faithful reproduction is the task of the historian. The historian, in this view, reconstructs events as they actually happened and reproduces them in a narrative the truth of which resides in its correspondence between the story told and the story actually lived by people. According to this view, thus, the literary aspect of historical narrative is expected to be limited to only a few stylistic embellishments - as opposed to the kind of inventiveness presumed to be inherent in mythical and fictitional narratives.

The criterion for distinguishing between mythical and historical narratives would thus consist in the reality of the latter as counterpoised to the unreal or fictitious character of the former. Recent theories, though, have sharply questioned this view. ${ }^{176} \mathrm{~A}$ variety of approaches, ranging from French structuralism and post-structuralism, to historians drawing inspiration from the Annales group, to literary theorists and philosophers such as Barthes, Foucault and Kristeva, tend to dissolve the distinction between "real" versus "fictitional" narratives by arguing that there is no ontological difference between the two. Notwithstanding the huge differences between such approaches, they all emphasise that a narrative is not only a form that can or cannot be added to the content without altering it: narratives, in this perspective, are always forms already full of content, and thus powerful means for the production of meaning so that an "objective narrative" would be impossible. Thus according to this view, mythical and historical narratives would not be counterpoised 
as "fictitious" versus "real" stories, but they would tend, rather, to converge: history, as some have argued by pushing this argument to its extreme formulation, would then be nothing but the myth of Western societies (Friedman 1992, Young 1990).

Thus, whereas Fernand Braudel for instance has attacked narrative history as intrinsically "dramatising" of reality, Roland Barthes has, from another point of view, challenged the very distinction between "historical" and "fictional" narratives, whereas, more recently, other authors of postmodern inspiration have dissolved the opposition "myth" versus "history" by sustaining that both are the products of a politics of identity. In all these cases, thus, the idea of an intrinsic opposition between historical versus mythical narratives has been reversed into its opposite, i.e. the thesis of their essential coincidence.

Notwithstanding some common assumptions to these disparate theoretical positions, such as, for instance, the common emphasis on the language-mediated character of the human experience of the world, they all clearly bring very different issues to the fore. According to Braudel, what is wrong with the narrative history is that it pretends to describe things as they really happen, but it consists in fact of a heavily interpreted account of them, an authentic philosophy of history. In particular, that which he criticises in this approach is the fact that, for the narrative historians, the life of human beings necessarily assumes the form of a drama, dominated by the actions of often exceptional individuals who emerge as the very protagonists of history: i.e. the masters of their own as well as our fate (Braudel 1950: 11).

Narratives, according to this view taken by all the historians following the Annales approach, are intrinsically novelising and even dramatising of reality: to this kind of historiography, they oppose the need for a "scientific" reconstruction of reality. This, they will argue, can only be accomplished by looking at deeper and long term historical processes, instead of personalised and dramatised events.

As has been noted, though, this position was born more as a justification for the promotion of a historiography devoted to the analysis of "long-term" impersonal processes in demography, economics and ethnology, rather than as an incentive for analysing the nature of "narratives": the rejection by this historiography of narrative history is due to a distaste for its conventional subject matter, i.e. past politics, as much as to their conviction that narratives are inherently "novelising" and therefore anti-scientific (White 1987: 32). The suspicion that is not so much the intrinsic dramatic nature of narrative that is at stake

${ }^{176}$ For a reconstruction of the debate see for instance White 1987, Jenkins 1997, Stråth 2000. 
here, but rather the distaste for a genre of literature focused on human agents as masters of their own destiny becomes legitimate.

To the view of narrative as an intrinsically dramatising form is opposed nothing less than the whole literary experience of the last century. As modemist literature clearly shows, it is in fact possible to narrativise without novelising and dramatizing. Indeed, at least from Pirandello onwards, it was even a common experience to view theatre that did not entail dramatisation. The point of the discussion then becomes to investigate what a narrative properly consists of and to what extent writing history without narrative is possible. In other words, do we have narrative only when we talk about "dramatised" and "novelised" political events, or are they much more pervasive than this view suggests?

According to Roland Barthes, for instance, narratives are much more pervasive than dramas, since they are almost ubiquitous. Barthes holds that narrative, with its pervasiveness and its ability to be expressed with the most widely differing materials and languages, is "international, transhistorical, transcultural: it is simply there, like life itself [...]. Under this almost infinite diversity of forms, narrative is present in every age, in every place, in every society; it begins with the very history of mankind and there nowhere is nor has been a people without narrative" (Barthes 1966: 78).

This does not mean though that, according to Barthes, every narrative is a myth. ${ }^{177}$ In his The discourse of history, Barthes seems to hold that history can be represented in different ways, some of which are not mythological in as far as they do overtly call attention to their own process of production and indicate the constructed rather than found nature of their object. When, at the beginning of this essay, Barthes states his intention to show that historical discourse does not differ from imaginary narration, it is most probably the pretension of an objective account of history that he is criticising. As he asks,

"the narration of past events, commonly subject in our culture, since the Greeks, to the sanction of historical "science", placed under the imperious warrant of the "real", justified by principles of "rational" exposition - does this narration differ, in fact, by some specific feature, by an indubitable pertinence, from imaginary narration as we find in the epic, the novel, the drama? (Barthes 1967: 127).

The question is clearly rhetorical. Barthes is persuaded that by simply looking at its very structure, one can see that this kind of historical discourse is in its essence a form of

${ }^{177}$ On Barthes's conception of narrative see also Chapter 5. whereas on his conception of myth see Chapter 12. 
ideological elaboration: historical narratives are the result of an "imaginary elaboration", i.e. of a performative speech-act through which the utterer of the discourse "fills out" the place of the subject of the utterance. It is this performative speech-act that is responsible for what Barthes calls the "reality effect", i.e. a new meaning that is extensive to all historical discourse and ultimately defines its pertinence and its reality itself. Thus, Barthes concludes, "historical discourse does not follow the real, it merely signifies it, constantly repeating "this happened", without this assertion being anything but the signified wrong side of all historical narration" (Barthes 1967: 139).

According to Barthes then, it is quite understandable why at the privileged moment when history attempted to constitute itself as a genre, i.e. in the nineteenth century, historiography should have come to institute narration as a privileged signifier of the real: narrative history refuses to assume the real as a signified and thus, paradoxically, the narrative structure, which was elaborated in the crucible of fictions and is the hallmark of myth, becomes for these historians the very sign and proof of reality (Barthes 1967: 140). Barthes thus contrasts this narrative history with what he considers a "veritable transformation" of contemporary historiography, which, by shifting the emphasis onto structures rather than events, has, in his view, liberated history from narrative (Barthes 1967: 140).

Clearly, for Barthes narrative always implies a form of "distortion" (Barthes 1966). He made the point explicit in his "Introduction to the Structural analysis of narrative":

"The function of narrative is not to "represent", it is to constitute a spectacle still very enigmatic for us, but in any case not of a mimetic order. The "reality" of a sequence lies not in the "natural" succession of actions composing it, but in the logic there exposed, risked and satisfied [...] Narrative does not show, does not imitate; the passion which may excite us in reading a novel is not that of a "vision" (in actual fact, we do not "see" anything). Rather it is that of a meaning, that of a higher order of relation which also has its emotions, its hopes, its dangers, its triumphs" (Barthes 1966: 124).

In his Mythologies, Barthes sustained that myths are a form of ideological distortion of reality, and in particular one that presents that which is a product of contingency as natural, and therefore, eternal (Barthes 1957). Narrative history is also intrinsically distorting in this sense because it presents as "facts" that which is instead the constructed spectacle of a narrative. Even admitting Barthes' definition of myth and ideology as distortion, though, the problem within this perspective remains that, not only myth, but all kind of narratives, both mythical and historical, in as far as narrative is distorting per se are, as a consequence, 
to be characterised as "distorting" and thus "ideological" (in Barthes's use of the term). How then can we distinguish between more or less mythological historical narratives? In other words, is there no historical narrative without distortion? What is the "reality" that they would distort?

As we have seen in his approach to narrative, Barthes moves from the assumption, drawn from the Russian formalists, according to which one can distinguish between two levels in a narrative: that of the story or argument of the narrative and that the discourse or organisation of the argument, this latter only comprising tenses, aspects and modes of the narrative (Barthes 1966: 87). ${ }^{178}$ But can these two levels really be distinguished? Is there any "natural" succession of events that only later comes to be organised? If Nietzsche is right, as Barthes himself will recognise one year later, in saying that there are not facts as such but we must always begin by introducing a meaning in order to have a fact (Barthes 1967: 138), then there is no basis for distinguishing between a "natural" succession of events from their "organisation" (Barthes 1966: 124). In other words, there is not, properly speaking, a "natural" sequence of events since: as far as we perceive of a succession of events, they are always somehow already "organised" and thus invested with a meaning. To put it bluntly, whatever earlier stage of the perception of a sequence of events we take, the working of organisation has always already started.

Contemporary theorists have pushed this kind of argument further. Robert Young for instance seems to hold that if writing history always implies a process of selection and organisation of events in a narrative plot, i.e. in a totality within which only events are conferred a meaning, then the writing of history does not differ from the activity of creating a myth (Young 1990, I). In particular, in his view, the idea of "history" always reflects a totalising mode of organisation of events that is not only particularistic because, as Foucault sustained, each society has its own way of organising knowledge, but it is also mythological because it is based on the exclusion of the other's perspective and thus, most often, results in the absolutisation of Western ethnocentrism (Young 1990).

History, so Young concludes, should then better be seen as simply a "white mythology", i.e. "the "preposterous off-spring of a distorting egocentric illusion to which the children of a western Civilisation have succumbed like the children of all other Civilisations and known primitive societies" (Young 1990:19). The illusion consists here in the identification of the history of provincial Western societies with History writ large.

${ }_{178}$ For a discussion of Barthes' treatment of narrative see Chapter 5. 
With regards to this view, the emergence of postmodernism is thus the sign of Western culture's awareness that it is no longer the unquestioned and dominant centre of the world (Young 1990, I).

Young is certainly right in his remark that postmodernism has brought about a new self-consciousness about a culture's own historical relativity and thus a loss of the sense of absoluteness of any Westem account of History. This new self-consciousness is perhaps its more permanent result. If one, however, were to further ask in what precisely the mythological aspect of the writing of history consists, two possible answers are available in Young's account. In the first place, Young introduces the concept of mythology by quoting a passage from Derrida's critique of metaphysics as "white mythology". The mythological aspect consists here in the illusion of the universality of metaphysics which calls itself "Reason" but is in fact an "Indo-European Mythology", i.e. the mythos of a specific idiom" (Young 1990: 7). Myth, however, is here simply used in the polemical sense of illusion and, therefore, can be indifferently applied to both history and metaphysics as expressions of logocentrism. Young's criticism seems to be directed toward a certain way of writing history, i.e. one that surreptitiously presents a specific history as history sans phrase (Young 1990:19); and, indeed, the white mythologies denounced in the title of his book are all those theories which, starting from Marxism, strive towards the idea of a unique "world history" i.e. of history as totality.

A somewhat different argument is put forward, however, in the second chapter of his book in which he criticises Sartre's attempt to save the Marxist idea of history as a continuous totality. By reading Lévi-Strauss's structuralist critique of Sartre as an example of deconstruction, Young suggests, with Lévi-Strauss, that history in general is the myth of modern man (Young 1990:45). Now it is the use of chronology itself, the code most often used by historians, which is said to create the illusory impression of a uniform, continuous progression; and it is in this sense that is said to be a myth. Dates, he observes, tell us something only in as far as they are members of a class which, in turn, may or may not correspond to other classes such as periods, millennia, ages and therefore always reflect a specific organisation of an event (Young 1990:46).

This is a crucial point. Even if one rejects Young's polemical usage of the concept of myth as illusion, his remarks over chronology must be further discussed. Young seems here to suggest that the simple organisation of events according to a chronology implies a high degree of choice and interpretation. However, to this view one can object even the 
very perception of "one or more events" already implies a process of selection and therefore organisation for what $e$-venit. Indeed, as we have suggested in Chapter 5 , there are no events without them being already organized.

On the other hand though, while narrative always implies a certain organisation, "organisation" does not necessarily mean the superimposition of a "dramatised" form, nor even a "distortion" through the imposition of a "fictitious coherence" that would otherwise lack reality. Indeed, events in as far as they mean something to us, always already exhibit some kind of organisation. The point, therefore, becomes rather to determine the degree of this organisation. Indeed, if in order to have a narrative we merely need a sequence of events, one must then recognise that not all sequences of events constitute a drama. And, as we shall see, in contrast to myth, historical narratives necessarily presuppose the former, but not the latter.

Narratives presuppose a plot that organises events: it is the plot that confers events a meaning as part of a whole. But the point is that this whole does not need to be a dramatic plot, nor even a "coherent" whole, as modernist literature shows. It just needs to be a whole. And, as we shall see, it is only when this whole that constitutes a narrative becomes "dramatic" that historical narratives can come to work as political myths. In other words, in order to have a historical narrative working as a myth, something else other than a mere narrative is needed. Let us dwell for a moment on the possible forms of historical narrative. What kind of forms do they take?

Hayden White faces the problem in his The content of the form: narrative - this is his major argument - is not an empty form that can or cannot be added to a given content, but it is rather already a content in itself (White 1987: $\mathrm{x}$ ). Thus, if narrative always brings content with it, the problem becomes to determine what kind of content is entailed in each single form of historical writing. In the first of the essays collected in The content of the form, White analyses three different examples of historical genres - annals, the chronicle and narrative history - and looks at the role played by narrative within them.

Annals, he observes, typically consist of a lacunose lists of events, where there apparently are none of the elements that we traditionally associate with narrative: there is no central subject, no central characters, no well marked beginning, middle and end, as well as no narrative voice whatsoever: apparently, thus, no narrative at all (White 1987: 70). Subsequently, however, he takes a specific example: the Annals of Saint Gall. By looking more carefully at this lacunose list of events, it comes to light that there are criteria 
according to which "events" are ordered as well as on the basis of which they are given the status of events at all (White 1987: 70).

Indeed, in all annals, and this is the sense of their name, events are registered under the year in which they occurred; the years are then ordered chronologically and for each year only what it is held to be most important is actually ranked as an event. Thus, in the Annals of Saint Gall, we find "Charles fought against the Saxons" next to the year 720, the registration of "great crops" next to "722" and nothing next to " 723 ", "724" etc. whereas the entry "732" registers that "Charles fought against the Saracens at Poiters on Saturday", where the fact that the battle took place on Saturday seems to be given the same weight as the "great crops" of 722 or the fact that, in 725 , "Saracens came for the first time". Clearly thus, there is an organisation of events even in annals: "there is surely a plot, so writes White, if by plot we mean a structure of relationships by which the events contained in the account are endowed with a meaning by being identified as parts of an integrated whole" (White 1987: 9).

What then differentiates Annals from other types of historical genres such as chronicles or historical narratives? Chronicles, White observes, are held to be superior forms of historical representations because of their greater comprehensiveness, their organisation of material by topics and reigns and their greater narrative coherence. The chronicle, for instance, has a central subject such as the life of an individual or a town or an institution or some great events such as war or crusades (White 1987: 16). Still, White observes, there is something that distinguishes the chronicle from other superior forms of historical narrative: chronicles - like annals but unlike the history - do not so much conclude as simply terminate; typically they lack closure, that summing up of the "meaning" of a chain of events that we normally expect from well-made stories. Chronicles may promise a closure, but usually do not provide it, and this is the reason why the nineteenth century editors of the medieval chronicles denied them the status of genuine history (White 1978: 16).

In contrast to both annals and chronicles, the story told by narrative history does not simply terminate, but actually concludes. All the narrative expectations of a reader are indeed satisfied: there is an identifiable subject, there is a well constructed plot with a beginning, middle and a proper end to the story: in a word, there is closure, a completeness that was absent in "inferior" forms of historiography. And according to White, the fullness and completeness of narrative that we experience in "superior" forms of historical narrative signals to us that what was lacking in the annals' incomplete list of events is indeed the 
notion of centre with respect to which to rank events: there is no single perspective that enables the annalist to make a complete story out of scattered events and these, as a consequence, appear to lack the ethical significance that is provided by a closed story (White 1987).

Going back to the Annals of Saint Gall, White argues that there is a correspondence here between the absence of a closed narrative structure and the absence of a social centre providing a single perspective for ranking events. Without such a social centre, Charles's campaigns against the Saxons remains simply a "fight", the invasion of Saracens simply a "coming", and the fact that the battle of Poitiers was fought on Saturday as important as the fact that it was fought at all or the fact that the year 722 witnessed great crops (White 1987: 11). Any well-made story, we can add, has a moral, and the reason why the annals seem to lack the structure of a real story is that they do not have any explicit moral to relate.

This analysis of the annals' form, according to White, suggests that Hegel was right when he stated that a genuinely historical account has to display not only a certain form, namely the narrative, but also a certain content, and that this content coincides with a "political order". The ranking of events always reflects criteria, and their ranking in the kind of historical narrative that Hegel was referring to clearly reflects a political criterion. Thus, as White points out, for Hegel the content of the specifically historical discourse was not the story of "what happened", but the peculiar relation between a public present and a past that a state endowed with a certain political constitution (White 1987: 29). As we read in Hegel's passage from the Lectures on the Philosophy of History, "in our language the term History unites the objective with the subjective side, and denotes quite as much the historia renum gestarum, as the res gestae themselves; on the other hand, it comprehends not less what has happened, than the narration of what has happened. This union of the two meanings we must regard as of a higher order than mere outwards accident; we must suppose historical narrations to have appeared contemporaneously with historical deeds and events" (Vorlesungen über die Philosophie der Geschichte, Einleitung, C).

The historical narrative to which Hegel refers, according to White, unlike the Annals, reveals to us a world that is "finished", "done with", "over". They exhibit a narrative closure that precisely because it is too embarrassing has to be presented as "found" in the events rather than placed there by narrative techniques. Indeed, it is precisely because 
narrative history provides us with a degree of coherence to which we ourselves aspire that the events presented by the narrative appear real; as White concludes:

"The demand for closure in the historical story is a demand, I suggest, for a moral meaning, a demand that sequences of real events be assessed as to their significance as elements of a moral drama. Has any historical narrative ever been written that was not informed not only by moral awareness but specifically by the moral authority of the narrator? It is difficult to think of any historical work produced during the nineteenth century, the classical age of historical narrative, that was not given the force of a moral judgement on the events that it related (White 1987: 22; emphasis added).

According to this later suggestion, one could assume that historical narratives and political myths fundamentally coincide: in both cases their "narrative organisation" would indeed reflect a need for significance, and therefore the need for events to be assessed within the plot of a moral drama. In particular, if political myths are the working on a narrative that responds to a need for significance and historical narratives stem also from "a demand of real events to be assessed as to their significance as elements of a moral drama", then there seems to be no difference between the two. Furthermore, whereas White seems to hold that not all forms of historical writing directly address a need for significance, and seems therefore to limit his claim to narrative history, more recently there have been authors who seem to extend the same remark to all kinds of history.

According to Jonathan Friedman for instance, history is a mythical construction because it is always a representation of the past subordinated to the establishment of an identity in the present. In his article on "Myth, history, and political identity", he states that an objectivist history must necessarily be produced in the context of a certain kind of selfhood, namely one that is based on the radical separation of the subject from any particular identity, and which objectifies and textualises reality (Friedman 1992: 194). In this sense, there would then be no difference between myth and history: the common understanding of history as a stream of events or as a temporal continuum whose empirical existence is unquestionable would, in turn, be a mythology - or better the peculiar myth of Western societies (Friedman 1992: 206).

We have seen that Young sustains a similar thesis, but he seems to limit it to those accounts presenting the history of westem societies as the History sans phrase. Friedman is an anthropologist and justifies his claim that history is mythical through the analysis of two case studies. In this article "Myth, history, and political identity" he analyses in the first 
place the shift in the perception of the eighteenth century Greeks of their previous history from that of "Romans" (Romoioi) to that of "Greeks", or heirs of the Hellenic civilisation. In a second step, he moves on to analyse the Hawaiians' reconstruction of their history as opposed to Westem "history". However, this seems not to be sufficient to sustain the proposition that myth and history coincide because both the examples clearly deal with two peculiar historical narratives, i.e. narratives that are manifestly linked to two situations of struggle over a political identity.

Friedman moves from the observation that the $18^{\text {th }}$ century construction of Greek national identity is largely due to the activity of a class of expatriate Greek merchants who, in contrast to a discontinuous Roman, Byzantine and Ottoman past, were led to rediscover Ancient Greece via Western European self-identity: in this latter, from the Renaissance onwards, Greece played a pivotal role as the birthplace of everything specifically "Western". Thus, Greek national identity consisted in the importation and establishment of the European identification of Greece, just as Greek history became the European history of the Ancients (Friedman 1992: 195). The establishment of a particular history was the work of a process of political identity construction, both for Europe and for Greece as an emergent periphery in the European world system. Thus, Friedman shows how, whereas Greek history internalises the extemal gaze of its European other, making Greece, in its fashion, the ancestor of Europe instead of a mere political and economic periphery, Hawaiian history extricates itself from Westem dominance by projecting a value system produced in the modem context onto an aboriginal past (Friedman 1992: 207). From the analysis of these two case studies it is patent that - as the very title of the essay also indicates - Friedman's focus is more on the way in which historical narratives are elaborated and re-elaborated according to a certain politics of identity rather than on what characterises historical narratives per se.

If Friedman can conclude that history is largely mythical, this is because he chooses these two case studies where historical and mythical narrative do indeed coincide. But can we conclude from these two examples that history is always mythical? Certainly history is always positional. ${ }^{179}$ As much as myth, history always reflects the point of view of the present and is continuously retold from this point of view.

\footnotetext{
${ }^{179}$ It should be clear from what precedes that when we speak of "history", we speak in fact of the "writing of history": history exists only in as much as it is accessible to us and therefore only as already interpreted events.
} 
In the first place, historical narratives select what constitutes an "event". In this sense, they are constructed on oblivion as much as on memory (Stråth 2000). The process of the selection of events can go from their deliberated occultation to their effectual perception according to non-intentional criteria. Secondly, as we have seen, events thus identified also go through a process of their further organisation and elaboration - without though, in reality, it even being possible to distinguish between the two moments of selection and organisation.

Thus, Friedman is right when he points out that history is always the organisation of the past in terms of a present situation: the selection-organisation of events cannot but reflect our present condition and, therefore, also our future hopes and expectations. The past is always constructed according to the conditions and desires of those who produce historical texts in the present. And, as we shall see in the next chapter, identity in the present is also organised in terms of a past, as well as of a future, that is already organised by the present: this is indeed the circularity that is constitutive of the social-historical. Political myth - this is the major point - also operates from the point of view of the present, but it does so in a somewhat different way.

Let me illustrate the point by going back to Friedman's two case studies. In fact, both the Greek and the Hawaiian examples point to the fact that the mythical side of the historical narrative analysed consisted precisely in their being part of a politics of identity: in order to construct a common Greek or Hawaiian political identity the past needed to be anchored to a viable present. In other words, they show that, to put it bluntly, myth is the politics of history: it is precisely in order to spell out this potential political side of the historical narratives analysed that Friedman has recourse to the concept of myth.

Analogously one can argue that there is nothing mythical per se for instance in the identification of history with the history of Western societies that Young criticises as "white mythologies". On the other hand, he is right in saying that this narrative can come to play the role of a political myth. To put it in Sorel's words, myth always contains a determination to act, and this determination become specifically political when it addresses specifically political conditions. Indeed, it is when it comes to political actions and conditions that historical narratives can work as political myths. If myth and history - as we have seen - with some exceptions share a narrative form, ${ }^{180}$ what they differ in is that myth,

\footnotetext{
${ }^{180}$ Not all historical writings are indeed narrative. Historical statistics are perhaps a good example: one could argue that they are a sequence of events, but they would still lack a plot in order to be classified as narratives. For a discussion of the concept of narrative, see also above Chapter 5.
} 
in order to nourish a determination to act, has to put a drama on the stage, or better, it has to be received as a drama. Political myths are stories that make their moral explicit in order to prompt political action. Political myths are thus "positional" in a different way respect to the way in which history is positional. In other words, political myths must directly respond a need for significance, whereas this is not necessarily the case with historical narratives.

Political myths, as we have seen, have a particularistic nature, because they must provide significance here and now, otherwise they cease to be political myths. "To be significant" always means "to be significant for someone and under certain conditions". As a consequence, there are no universal political myths, but only particular ones - and this at least partially explains why political philosophy has often neglected the topic. There can be attempts at a "universal history", but not at a "universal political myth". What is a political myth for certain subjects, here and now, may well no longer be a political myth even for the same people in another context or for different people in the same context.

Thus, notwithstanding the fact that, as we have seen, political myths and historical narratives quite often are so intermingled as to coincide, analytically speaking we should keep the two categories separate. This can enable us to grasp the differences between certain phenomena that would otherwise be lost. Whereas not all historical narratives are necessarily political myths, not all political myths are historical narratives. The narrative of the general strike, that of the society without class or the myth of the millennium, all of which have worked in the past as political myths, are, for instance, all constructed in the future dimension. Thus, even if one could argue that they presuppose certain historical narratives, they are not themselves genuine historical narratives.

This leads to a crucial point. The working on myth operates with a degree of freedom that is impossible in historical narratives. Certainly, as we have seen, the historian also looks at the past in light of the present and future but, to use Friedrich Schlegel's expression, he is a "turned-back prophet." 181 Both historians and myth-makers are prophets since both look at the past and at the present in light of the future, but the fact that the historian is a "turned-back prophets" puts on him further constraints that are not pending on the activity of the myth-maker. For instance, typically today, the mythmaker will be

\footnotetext{
${ }^{181}$ The "prophet", in F. Schlegel"s use of the term, is a "poet-philosopher" (Schlegel 1798, Fragm. 249) and thus something close to an ideal-typical mythmaker. Nevertheless, as we have seen, a myth rather consists in the working on myth and there is no such thing, therefore, as a single mythmaker: at best we could speak of myth-makers/receivers.
} 
believed because he tells a variant of a story that addresses the need for significance, whereas the historian - at least the modem historian - will have to rely on method. ${ }^{182}$

Tudor made a similar point when he wrote that the understanding provided by myth is a directly practical understanding, i.e. an understanding in which human beings consider the world that confronts them, not as an object of disinterested curiosity, but as the direct material for their activity (Tudor 1972: 123). One can certainly question the idea that the activity of the historian could ever be completely "disinterested", but Tudor points in the right direction when he says that sometimes human beings engaged in practical affairs certainly do think, but think in a different way. For instance, he sustains, people confronted with the prospect of death, disgrace or serious deprivation will not easily be persuaded to see other fellows' points of view, nor are they likely to engage in disinterested reflections on human existence. What they require is the confidence to act, and this confidence is often to be induced by their holding the firm conviction that their cause is just and that they are certain to emerge victorious (Tudor 1972: 134).

Certainly this is an extreme case, but it points out that the types of interests at stake, both in the working on myth and in historical research, can coincide, but they may also diverge. This does not imply though that, as Tudor concludes, in the practical understanding provided by myth, in contrast to history, "no doubt, some distortion of facts does occur" (Tudor 1972: 123). As we have seen, historians, even without any manipulative intent, also distort facts; or rather, the very notion of fact always implies a process of selection, choice and organisation so that it becomes difficult to determine where distortion starts and whether it could not have occurred.

The point therefore is not to counterpoise "practical" and thus "distorted" understanding versus "disinterested" and thus "faithful" reconstructions of events. Rather it is to contrast a discipline that was constituted around a method, with an activity, i.e. the working on myth that does not share the advantage and disadvantage of a method. Indeed, properly speaking, to talk of a "myth-maker" is an abuse of language: not only, as we have seen, is a myth made by its production-reception but it is an entire working on myth that is always at stake. This does not mean that a similar working on historical narrative does not occur: the professional historian does not operate in the social vacuum. Still, the very fact that there could be a professional historian is the sign of a difference: the activity of the

\footnotetext{
${ }^{182}$ Ankersmit too, who sustains that no writing of history is possible without "representation", recognised the centrality of the methodological aspects: it is here that the working of what he calls "transversal reason" can be seen (Ankersmit 2001).
} 
historian lends itself to a definition through a method. Notwithstanding the endless discussion that this point may open over the nature of this method, it still remains that the idea of a method implies that of an organon, i.e. of a series of more or less standardised rules and practises against which the correctness of the account will be assessed.

No "mythical method" exists or has ever existed. And this is probably because most often, as has been observed, political myths operate at the level of unquestioned beliefs held in common by social groups (Flood 1996). Thus, whereas narratives deriving from a method are somehow visible, political myths are difficult to even perceive and to be determined. As Lance Bennett observed, dealing with the North American case, political myths are difficult to analyse because they are such basic components of everyday perception: they cannot be seen as the things that the people see when they look at the world, because they are rather the things they see with. "Myths, he concludes, are truths about society that often remain unperceived because they are woven throughout everyday social discourse from dinner table conversation, to the morals of television programs, to the lofty policy debates of congress" (Bennett 1980: 167) ${ }^{183}$.

Certainly historical narratives are also a part of the social imaginary constituted through different kinds of social practices. And indeed, it is practically sometimes very difficult to distinguish between historical and mythical discourses, since in our everyday life they are often interwoven. Historical narratives do not live only in the libraries and archives where the modem historian is asked to produce them, but they also emerge out of social life. On the other hand, in as far as historical writings started to be defined in terms of a method, there has been the possibility to perceive them and thus criticise them on the basis of their formal correctness: the modem historian has to make footnotes; he is expected to refer to evidence, i.e. to other, in principle revisable, narratives. Typically today, he is asked to refer to documents, archives and all material that constitutes forms of "rationalised memory" i.e. the set of information about and accounts of the past as it is contained in archives, processed in the form of written or visualised narratives that are accessible on demand (White 2000). ${ }^{184}$

\footnotetext{
${ }^{183}$ On Bennett's analysis see in particular Chapter 12.

184 White distinguishes between "rationalised memory and "traditionalised memory" as information about and accounts of the past latently stored in fables, tales, commonplaces, customs and prejudices. White argues that, whereas rationalised memory might comprehend traditionalised knowledge, the reverse is not the case. One could criticise this latter statement but the distinction between the two categories is certainly helpful in order to stress that the two may also enter into tension.
} 
Thus, whereas the work of the historian, at least in modern Western societies, is locatable, the working of myth is difficult even to perceive, and this is the reason why it could never be formalised through a method. Both, at the same time, are constitutive of those imaginary significations that contribute to providing a meaning to everyday experience and without which no society could ever survive. After the so-called "linguistic turn" and the emergence of constructivism, different approaches have been pointing to this crucial dimension of social life. The exponential number of publications on "symbolic construction" and the "invention of societies and communities" has pointed out that no social life is possible outside of a symbolic network. ${ }^{185}$ Political myths and historical narrative both contribute and often converge in the production of these social significations, but they do it in somewhat different ways. To put it bluntly, myths stem from a need for significance. Historical narratives can also, in principle, come from a simple need for meaning.

More than thirty years ago, Comelius Castoriadis introduced the concept of social imaginary in order to stress what he still perceived to be a neglected side of social life. His reasoning was quite straightforward: all acts, both individual and collective, without which any society could survive - labour, consumption, love, war etc - are not only and not always directly symbols themselves, but are impossible outside of a symbolic network (Castoriadis 1975: 181). All functions performed within any society are, in fact, "functions of something", i.e. they are functions only in as far as their ends can be defined. These ends, which vary from society to society as well as from one epoch to the other, can only be defined at the level of those social significations without which no social function or need could ever be defined: this is the level at which the "social imaginary" operates (Castoriadis 1975).

Castoriadis moves from the insight that a functionalist view, i.e. a view reducing the problem of social significations to the ambit of the functional, is only partially correct: as far as it aspires to present the whole truth about the nature of the social-historical it is a mere projection. It pretends to identify a general rule, but in fact it projects over the whole course of history an idea derived not even from the everyday life of Western capitalist societies - that, notwithstanding the processes of rationalisation are always only partially

\footnotetext{
${ }^{185}$ On the symbolic dimension of community, see for instance Edelman 1964, 1988, Cohen 1985. Cohen moves from Geertz's definition of the human being as "an animal suspended in a web of significance", but he does not distinguish between significance and meaning, both conflated under the heading of symbolism (Cohen 1985).
} 
functional - but, rather, from what it would like these societies to be (Castoriadis 1975: 197). Capitalist societies are no exception: rather, given the crucial role played by the social creation of needs, they ever more manifestly exhibit the working of the social imaginary (Castoriadis 1975). Any society continually defines and redefines its needs and none of them can therefore ever survive outside of the imaginary significations that constitute it and are constituted by it: the institution of a society presupposes the institution of imaginary significations that must, in principle, be able to provide meaning for whatever presents itself.

Certainly, Castoriadis observes, there are limits to this symbolic order. To put it in Blumenberg's terms, the world is always a work of art, but it can never be a total work of art (Blumenberg 1979). The working of the social imaginary must always start from the material that "it finds already there": there are limits posed by nature itself, (so that, for instance, all societies define the meaning of nourishment, but they all must take the need for it into account), by the rationality, i.e. the coherence of the symbolic edifice as well as the limits imposed by history itself: every symbolism is constructed on the ruins of precedent symbolic buildings and even in order to radically break with it it has to start with those very premises (Castoriadis 1975: 188). Notwithstanding all these limits, the social imaginary has a capacity of virtual universal covering so that any irruption of the raw world can immediately be treated as "a sign of something", i.e. it can be interpreted away and thus exorcised. Even that which collides with this order can be subject to a symbolic processing: transgressions to social rule can become "illnesses", completely alien societies that are fundamentally at odds with a given social imaginary can become "strangers", "savages" or even "impious" (Castoriadis 1988).

At the same time though, Castoriadis observes, the major threat to the instituted society is its own creativity. The merit of Castoriadis's concept of radical social imaginary is to point out that the instituted social imaginary is always at the same time instituting. No society could ever exist if the individuals created by the society itself would not create it. There seems to be circularity at the basis of the relationship between individuals and the social imaginary. This is the primitive circle of the institution of society that Spinoza also emphasised: society exists only if it can exist in the imagination of individuals that, in turn, could not exist without the society they are part of. ${ }^{186}$

${ }^{186}$ On this point, see also Chapter 8. 
The individual, thus, Castoriadis observes, is not contingent in relation to society. Society can exist concretely only through the fragmentary and complementary incarnation and incorporation of its institution and its imaginary significations in the living, talking and acting individuals of that society. Athenian society is nothing but the Athenians, he observes: without them it is only remnants of a transformed landscape, the debris of marble and vases, indecipherable inscriptions, worn statues fished out of the Mediterranean. But the Athenians are Athenians only by means of the nomos of the polis. It is in this relationship between an instituted society on the one hand - which infinitely transcends the totality of the individuals that "compose" it, but which can actually exist only by being "realised" in the individuals it manufactures - and these individuals, on the other, that we experience an unprecedented type of relationship which cannot be thought of under the category of the whole and its parts, the set and its elements and, even less, the universal and the particular (Castoriadis 1988: 145)

Still, Castoriadis seems to open up this circle when he speaks of an "absolute scission" between the two poles of the instituted/instituting social imaginary: the social-historical on the one hand ${ }^{187}$ and what he calls the "psyche" or "psychical monad" on the other (see in particular Castoriadis 1975: 470). The psyche is monadic since, in Castoriadis's view, it is "pure representational affective/ intentional flux", indeterminate and, in principle, unmasterable. Thus, according to this view, it is only through an always-incomplete violent and forceful process of socialisation that a social individual can be produced. According to Castoriadis, this happens through a process of schooling that starts with the very first encounter with language, in the first place the language spoken by the mother: in this way, the psyche is forced to give up its initial objects and to invest in (cathecting) socially instituted objects, rules and the world. Thus, it is through the internalisation of the worlds and the imaginary significations created by society that an "individual" properly speaking is created out of a "screaming monster" (Castoriadis 1988: 148)

As has been observed, Castoriadis's thesis about the monadic isolation and the fundamental "hetereogeneity" between the psyche and society seems to lead to a highly problematic, and thus untenable, metaphysical opposition (Habermas 1985, XI, Excursus). Once we find ourselves within the monadic isolation of the unconscious, it becomes difficult to even explain how communication is possible in the first place (Whitebook

\footnotetext{
${ }^{187}$ With regards to the relationship between the terms "society" and the "social- historical", the latter is preferable since, in contrast to the term "society", it does not suggest the idea of an entity endowed with clear-cut boundaries, which is contrary to Castoriadis's own idea of magmatic logic.
} 
1989). ${ }^{188}$ However, Castoriadis's insights into the role of the instituting and instituted social imaginary do not need to rely on such metaphysical assumptions. What appears at first sight to be a theory deeply dependent on psychoanalysis can in fact also be read from a different perspective.

Arnason, for instance, points out that Castoriadis's major contribution has been to link a radicalised idea of imagination with the problematic of meaning (Amason 1989a, 1989b). Castoriadis's work has certainly contributed to the recent rediscovery of the importance of images and imagination in social life as well as to the development of a much more complex view of social imagination. ${ }^{189}$ This is reflected in two aspects of his theory: first the idea of a "radical imagination", and second the emphasis on the idea of "social imaginary".

As for the first, the term "radical" has here the function to stress that, as Aristotle sustained, together with an imitative and reproductive or combinatory "phantasia", 190 there is also what can be called a primary imagination, that is the faculty of producing those "images in the largest possible sense (that of "forms", "Bilder") without which there would not be any thought at all, and that therefore precede any thought (Castoriadis 1994).

The reason why imagination came to be associated with the idea of fictitiousness is that it is created ex nihilo - not in nihilo or cum nihilo - and the Western ensemble logic, which starts with the identity assumption ex nihilo nihil, could not as a consequence but conceive of imagination as essentially non-existence. To this identitary and ensemblistic logic, which could never account for the fact that when " $x=x$ " is it is always " $x=$ non $X$ ", Castoriadis counterpoises the logic of magmas: this sees significations not as "determinate beings" but as "faisceaux de renvois" that are certainly always determinable but never determinate (Castoriadis 1975: V, 1).

Thus, to sum up, the expression "radical imagination" has the function of conveying two ideas: the connection with the idea of imagination and creation, and with the "radical" side of it, i.e. with the fact that "this imagination is before the distinction between "real" and "fictitious" or, to put it bluntly, it is because radical imagination exists that "reality"

\footnotetext{
${ }^{188}$ Whitebook argues that Habermas could not but sharply criticise Castoriadis's theory of the psyche: whereas Castoriadis starts with the monadic isolation and the problem then become to establish how communication is possible, Habermas starts, on the contrary, with the fact of communication and the problem then becomes how this can be deformed in the unconscious (Whitebook 1989).

${ }^{189}$ On the role of imagination in the study of social and political sciences see recently Rundell 1994 and Friese 2001.

${ }_{190}$ As Friese notices, it is again only in modern times that the term "fantasy" was definitely associated with the ambit of the fictitious and unreal (Friese 2001).
} 
exists for us - and therefore, one can add, it exists tout court - and thus it exists as it exists" (Castoriadis 1994).

Thus, as the concept of social imaginary points out, there is not a subject and a reality that stays facing it. Rather, the passage from the concept of imagination to that of imaginary precisely reflects a change from a subject oriented approach to a context oriented one (Amason 1994). Castoriadis's concept of social imaginary also has the function of underlining the notion that the definition of "reality" itself depends on the working of the instituting and instituted social imaginary, and not vice versa (Castoriadis 1975: 242; 1991:147).

The fact that, as we have seen in Chapters 2 and 3, the word "reality" comes into being only relatively late and that it has been conceived in very different ways, is the sign that the emergence of a new word, "reality", was also the emergence of a different conception of the "real". All societies have somehow constituted their "reality" and it is for this reason that any distinction between myth and history as "unreal" and "real" accounts respectively cannot be but of limited efficacy.

On the other hand, it is precisely by moving from the idea of the "radical social imaginary" that we can try to restate the difference between political myths and historical narratives. Indeed, if both myths and historical narratives are constitutive of the social imaginary, i.e. of the imaginary significations through which any society institutes itself by being at the same time instituted by them, they are so in a different way. Generally speaking, we can explain the difference between the two by saying that political myths do not only answer the need for meaning, i.e. that for a symbolic mediation of reality, but they must also coagulate and produce significance.

As a consequence, political myths can be seen as a site both for the construction of an instituting social imaginary and for the working of a radical political imagination. Myths are not simply symbols, and political myths in particular are not only mapping devices: they also contain a determination to act, and this determination affects the specifically political conditions of a given society.

Therefore the work on political myths is radical in two senses. On the one hand, because it operates at the level of the coagulation and reproduction of significance as it has been defined in Chapter 6 . Therefore, in contrast to historical narratives, political myths are often not even perceivable: there can be professional historians, but no professional mythmakers. Political myths are difficult to analyse because they are not only a part of the 
world that we experience, they are also, and foremost, the lenses through which we see this world.

If, in this sense, political myths contribute to the self-perpetuation of a given social imaginary, they can also, on the other hand, be one of the sites for the questioning of this same imaginary. Moreover, they can be the sites for the questioning of the specifically political conditions of an instituting and instituted society. Otherwise stated, the "not yet determined animal"(Chapter 6) is an animal that produces myth in order to satisfy her/his need for significance, but precisely because $s /$ he is always not yet determined s/he can also always (potentially) question her/his own conditions of existence.

Put in Castoriadis's terms, the idea of the radical character of imagination is also linked to the project of autonomy. As Castoriadis points out, if autonomy must be conceived as the possibility to give oneself one's own law, i.e. to institute a critical relationship with the discourses that are given, then imagination is also radical because, by its own creativity, it can also question not only what is given but also its own products (Castoriadis 1988, 1994).

If autonomy means interrogation, then political myths can be the site, not only for the instituting working of the social imaginary, but also for the opening up of the crucial question: "why these significations and not any other?". Clearly this does not mean that political myths are always means for interrogation. The working on myth can also tends towards a closure of meaning. ${ }^{191}$ As Castoriadis observes, it could even tum out to be the case that no autonomous society has ever existed, since all societies tend to conceal, by different means, the instituting dimension of the social imaginary. ${ }^{192}$ However, the concept of the radical imagination points to the fact that the working on political myth can also be the site for interrogation.

Castoriadis sees the creative dimension of imagination essentially as a capacity for interrogation, i.e. as a capacity for questioning the given. But there is another dimension of imagination stressed by Paul Ricoeur: for Ricoeur the creativity of imagination is linked to a capacity for fictionalising that we find in the logic of action. There is no action without imagination. People, as Sorel also has pointed out, need to represent their upcoming

\footnotetext{
${ }^{191}$ Some suggestions on the conditions under which political myths produce a closure of meaning can be found in Chapter 12.

192 Since the instituting dimension of the social imaginary is the major threat to the stability of the instituted society itself, it is against this threat that the strongest defences are set up. These consist in the denial and covering up of the instituting dimension of society through the imputation of the origins of the institution and of its social significations to an extra-social source, such as Gods, heroes or ancestors (Castoriadis 1988).
} 
actions in terms of a narrative that makes significance of their conditions. This capacity to fictionalise through the combination of unusual predicates, according to Ricoeur, is a capacity to "radically rethink" that he, employing Mannheim's terminology, calls "utopian" (Ricoeur 1994).

To conclude, political myth can also be one of the sites for the working of both these creative dimensions of imagination: as we have seen, for instance, the myth of the state of nature or that of the general strike can be both the direct means for questioning what is given as well as for utopian thinking and action. This does not mean that historical narratives are excluded from these dimensions: the concept of political myth simply signals that, in as far as historical narratives come to play this role, they are then no longer operating only as historical narratives but also as political myths. 


\section{MYTH AND IDENTITY}

In an early article on Die politische Theorie des Mythus, (1923) Carl Schmitt sustains the existence of a strict relationship between the emergence of a political theory of myth and the crises of parliamentarism. The theory of myth, he contends, is the most powerful sign of the decline of the rationalism of parliamentary thought (Schmitt 1923: 17). His argument can be summarised as follows: if myth is the "symptom of an energy", of an "enormous enthusiasm", then the mechanism of what he calls "the discussing, bargaining and parliamentaring procedures" cannot but appear as a "betrayal of myth" and a fundamental infidelity to the vital enthusiasm from which myth derives (Schmitt 1923: 13).

Schmitt, in the first chapter of his Political Theology (1922), had been identifying in a "philosophy of concrete life" the basis for his intellectual enterprise. Sovereign, so states his decisionist thesis exposed at the beginning of the book, is he who decides on the state of exception. According to Schmitt, and in contrast to common understanding, it is exception that creates the rule, and not vice versa: the exception precedes the rule both temporally and logically, since the rule, which in his view is only appropriate in the "prosaic conditions of normal life", proves nothing whereas the exception proves everything. Indeed, Schmitt continues, "in the exception the power of real life breaks through the crust of a mechanism that has become torbid by repetition"; therefore, a philosophy of concrete life cannot withdraw from the exception and the extreme case, but must be interested in it to the highest degree (Schmitt 1922: 13-15). 
It is moving from such vitalistic premises, not lacking in a Nietzschean echo, that Schmitt is led to privilege the moment of decision and exception to the following of a norm: it is in the former that the real life comes to light and breaks in a moment "the crust of a mechanism". As is well known, Schmitt is here referring to the debate on the institutions of the Weimar republic and expressions such as "crust of mechanism" are a form of criticism towards the working of its parliamentary institutions. Parliamentarism is identified by Schmitt with a form of "government by discussion": the principle of discussion and of reasoning that he saw at work in the institutions of the Weimar republic is, according to his vitalistic decisionism, the "strongest opposite" to the real life of myth (Schmitt 1923: 11).

Therefore, it is not by chance that his article on "Die politische Theorie des Mythus" also appears as the final chapter of the text where Schmitt analyses The Crises of Parliamentary Democracy. Here, significantly, the article appears with another title: "Irrationalist Theories of Direct Use of Force". The major part of the article is indeed devoted to analysing Sorel's view of myth, and, as we will see, it is by presenting his own interpretation of Sorel that Schmitt puts forward his view of political myth as a symptom of a national energy.

Myths, according to Schmitt's reading of Sorel, are the direct expression of concrete life, of a Bergsonian élan vital that is alien and also hostile to discussion and rational mediation. For this reason, Schmitt takes the emergence of the theories of myth as the clearest sign of the crises of parliamentarism. In Schmitt's reading, Sorel's myth stands to rationality as decision on the exception stands to parliamentarism; as a consequence, the rationalism of parliamentary discussion cannot but appear as a "betrayal" of the irrationality of myth. ${ }^{193}$ Thus, according to Schmitt, Sorel's theory of the general strike is necessarily linked, not only to Sorel's preference for violence over the institutional participation predicated by parliamentary socialists, but also to the intellectual choice for a sort of irrationalism that is substantially at odds with any form of discussion.

The only point where, according to Schmitt, Sorel was wrong was in his diagnosis of the contemporary forces for the production of myth. If myth, as Schmitt following Sorel argues, is the criterion for deciding whether one nation or a social group has a historical mission and has reached its historical momentum (Schmitt 1926:68), then we must

${ }^{193}$ On Schmitt's interpretation of myth as irrationality and particularly on the influence of Nietzsche for the development of this view see McCormick 1997: Ch2. 
conclude that the strongest myth of modernity is not that of class conflict, but that of the nation. The myth of class conflict, he observes, has been created by the diffusion of an image that was capable of intensifying all the emotions of hatred and contempt: this negative image of the bourgeois first fed by literati such as Stendhal or "the hatred socially déclassé genius of Baudelaire" was subsequently given a world-historical dimension by Marx and Engels, who made out of the bourgeois "the last representative of a pre-historical humanity divided into classes" (Schmitt 1926:74).

However, according to Schmitt's diagnosis, at the beginning of the twentieth century this image of the bourgeois as the last odium generis humani could no longer live out of the sheer instinct for class conflict and had to recur to a superior mythology, i.e. the national myth. ${ }^{194}$ The power of this latter was, in his view, proved by the experience of Italian fascism and by the fact that even the myth of class conflict had to assume the colours of nationalism (Schmitt 1926: 74). Also, other examples provided by Sorel in his Reflections prove, according to Schmitt, that the strongest myth of modernity is national: "the revolutionary wars of the French nation and the Spanish, and German wars of liberation against Napoleon are symptoms of a national energy" (Schmitt 1926: 75).

If myth thus is the expression of a great enthusiasm, of an energy that is already given, then Schmitt concludes that it is at the "myth of nation" rather than at that of class conflict that we have to look. What lies at the bottom of this "energy" is subsequently clearly stated:

"The more naturalistic conceptions of race and descent, the apparently more typical terrisme of the Celtic and Romance peoples; and then the language, tradition, and consciousness of a shared culture and education, the awareness of a community of fate (Schicksalsgemeinschaft), a sensibility for being different in itself (Eine Empfindlichkeit für das Verschiedensein an sich): all of that tends towards a national rather than a class consciousness today (Schmitt 1926: 75; translation mine).

All these elements explain why, thus, when it comes to a confrontation between the two mythologies, it is national myth that has always been victorious. "Italian fascism, for instance, depicted its communist enemy with a horrific face, the Mongolian face of Bolshevism; this has made a stronger impact and has evoked more powerful emotions than

\footnotetext{
${ }^{194}$ One must not forget that, in 1930, seven years after Schmitt's Die politische Theorie des Mythus. Rosenberg's Der Mythus des 20.Jahrhunderts" appeared, whose subtitle is significantly "Eine Wertung der seelisch-geistigen Gestaltenkämpfe unserer Zeit". For a discussion of Rosenberg, see Chapter 8.
} 
the socialist image of the bourgeois. [...] that was an example of the irrational power of the national myth" (Schmitt 1926: 75; emphasis mine).

Thus, according to Schmitt, myth is the symptom of an irrational force stemming from the consciousness of a common race and descent, traditions, language, the feeling of belonging to the same community of fate as well as a certain feeling of being different in itself. In other words, national myth is the symptom of a common identity. Myths are in this view the mere epiphenomenon of a deeper reality, of an identity that is already given and that finds its source in an irrational power that is fundamentally hostile to rational discussion.

It is not difficult to recognise in this theory of myth as irrationality a familiar discourse. Schmitt's treatment of myth reproduces the semantic apparatus and conceptual strategies of the Aufklärung by simply inverting its axiological connotation. In the Aufklärung, myth is the defeat of reason and, thus, the source of all evils, here it is the "great enthusiasm" that breaks through the crust of mechanism of reason; in both cases myth and rationality are set on two different and opposite grounds so that the two approaches, far from being opposite, converge on a fundamental point: myth and reason are heterogeneous and mutually irreconcilable. The suspicion, though, seems to be legitimate that this view is more that of Schmitt, who has in turn been deeply influenced by Nietzsche (McCormick 1997), ${ }^{195}$ rather than the result of an unbiased reading of Sorel.

As we have seen, Sorel does not in fact seem to conceive of myth in this way. Not only does he never explicitly associate myth with irrationality, but he explicitly engages himself in and calls for a rational discussion of the myth of the general strike. His opposition to parliamentarism stems from a rational preference for the general strike over institutional participation as a political means for obtaining certain ends, rather than from an intellectual rejection of rationality and discussion per se. On the other hand, Schmitt, who associates parliamentarism with rationality, could not but see in Sorel's preference for myth and direct action a form of irrationalism.

But there is more at stake. Schmitt conceives of myth as the product of a national energy, i.e. of a national consciousness that is based on elements - such as language, tradition and consciousness of a common fate - that pre-exist myth. On the contrary, Sorel presents the general strike as a means for creating a class consciousness that does not yet exist. The fourth chapter of the Reflections on Violence is devoted precisely to showing

${ }^{195}$ On Nietzsche's recovery of myth see Introduction to part II. 
that the general strike, by conveying in a sole image all the principles of Marxism, is the best means for creating such a consciousness. To put it bluntly, for Schmitt the myth is a "symptom" because it reflects an identity that is given; for Sorel it is the means for creating an identity yet to come.

The contrast between those two views signals one of the antinomies of social identity: identity is by definition "that which is identical to itself" but is at the same time "that which is different from itself" since it is necessarily the always changing product of history. Identity is a choice, if we look at it from Sorel's perspective, but identity is a destiny, if we turn to Schmitt. ${ }^{196}$ Political myths also reflect the same antinomy: they can be seen as both a symptom of an already existing identity, but also as a means for creating an identity yet to come.

This antinomy explodes at the end of the Crisis of Parliamentary Democracy where Schmitt, after presenting national myths as the symptom of an already existing national identity, points to the dangers that myth represents: myth, Schmitt now suggests, is by its very nature polytheistic, both because of "the pluralism of an unforeseeable number of myths" and because "every myth is in itself polytheistic" (Schmitt 1926: 76). Therefore, the feeling of belonging to a single community of fate, which he had before identified as the source and fundament of myth, is now seen as a unity that is crucially endangered by myth. Thus myth, conceived as the "symptom" of an already existing common identity, comes to be that which, with its intrinsically polytheistic nature, threatens the very deepest reality of which it would be a mere symptom.

If we now go back to the previous chapters of the Crisis of Parliamentary Democracy, we see that the same antinomy pervaded Schmitt's treatment of identity and democracy. Schmitt's major point in this text is that parliamentarism, i.e. the "government by discussion", is intrinsically linked to liberalism, but not to democracy. Schmitt defines democracy in terms of identity in contrast to liberalism. In particular, by returning to Rousseau's Social Contract he defines democracy as identity between rulers and the ruled (Schmitt 1926: 26, 27).

However, whereas Rousseau conceived of democracy as identity between rulers and the ruled in the sense that those who govern and those who are governed must be the same persons (i.e. as identity to themselves), Schmitt uses the expression "identity between

\footnotetext{
${ }^{196}$ On the idea of the antinomies of identity, see Wagner 2002. He distinguishes between three of them: "identity as choice or as destiny", "identity as construction or as reality", and finally "identity as autonomy or as domination".
} 
rulers and the ruled" in such a way that it comes to signify not simply identity between individuals among themselves, but also identity of individuals with each other, identity between these individuals and a tertium that is the nation, and finally even identity of this tertium with itself. This is clear later on in the text where he explains what he means by democracy as identity between rulers and the ruled:

"[..] Democracy rests on a string of identities: to this series belong the identity of governed and governing, sovereign and subject, the identity of the subject and object of state authority, the identity of the people with their representatives in parliament, the identity of the state and the current voting population, the identity of the state and the law, and finally the identity of the quantitative (the numerical majority or unanimity) with the qualitative (the justice of the laws) (Schmitt 1926: 26).

Thus, it is through such a holistic use of the term "identity between rulers and the ruled", which indeed seems to go well beyond Rousseau, ${ }^{197}$ that Schmitt can conclude that "democracy requires first homogeneity and - second if the need arises - elimination or eradication of heterogeneity" (Schmitt 1926: 9).

If one then further asks how this homogeneity is to be understood, then two opposite answers emerge from the text and we are faced with another antinomy. On the one hand, Schmitt seems to be quite straightforward in asserting that "the question is not one of abstract, logical-arithmetical games, but it is about the substance of equality, and as such it can be found in certain physical and moral qualities" (Schmitt 1926: 9; emphasis mine). As we have seen above, a more detailed list of these qualities includes: race and descent, language, tradition, a consciousness of a shared culture and education, the awareness of a community of fate (Schicksalsgemeinschaft) and a sensibility for being different in itself.

On the other hand though, later on in the text Schmitt equally strongly asserts that, in fact, such homogeneity never exists in concreto. Indeed, he openly states that "the various nations or social and economic groups which organised themselves democratically have the same people only in the abstract: in concreto the masses are sociologically and psychologically heterogeneous" (Schmitt 1926: 25).

Indeed even the passage quoted above, in which Schmitt spells out all the series of identities that constitute democracy (identity between the governed and the governing,

\footnotetext{
197 We cannot here enter a discussion of the difference between Rousseau and Schmitt's treatment of democracy. Let me only point out that, as is well known, an expression such as "the identity between the people and their representatives in parliament" could not but have appeared suspicious for a critic of representative democracy such as Rousseau.
} 
between the subject and the object of state authority, the identity of the people with their representative in parliament, the identity of the state and the current voting population, the identity of the state and the law, and finally an identity of the quantitative with the qualitative), is followed by a further fundamental qualification: all these identities, Schmitt writes, are in fact not a "palpable reality" (handgreifliche Wirklichkeit).

In other words, identity appears here not as a matter of an "objective" legal, political or sociological equality, but rather of what he calls "identifications" or "recognitions of identity" (Anerkennungen der Identität) (Schmitt 1926: 27). ${ }^{198}$ Thus, it is thanks to the idea if "identification" holistically understood that Schmitt can, for instance, conclude that democracy is not antithetical to dictatorship: "the will of the people - so he wrote - is always identical with the will of the people whether a decision comes from the "yes" or "no" of millions of voting papers, or from a single individual who has the will of the people even without a ballot, or from the people acclaiming in some way (Schmitt 1926: 27; emphasis added).

This is not the most appropriate space for entering into an accurate discussion of Schmitt's complex view of democracy and identity/ identification. But clearly, even from such a brief reconstruction, it is evident that the holistic way in which Schmitt uses the concept of identity can result in very problematic normative outcomes. They become patent in that Schmitt, moving from his definition of democracy in terms of identity between rulers and the ruled, can come to conclude that, in as far as the people "identify" themselves with the Führer, he can be said "to have the will of the people" and his decision, whatever it will be, is, as a consequence, always by definition "democratic" (Schmitt 1926: emphasis mine).

It might not be irrelevant to remember here that Nazism attempted to present itself as the saviour of democracy and Schmitt's theory, as reconstructed above, lends itself to such a political project. ${ }^{199}$ The assertion that a dictator can "have the will of the people" is however very problematic - not exclusively, but primarily due to its political consequences. In dictatorship, identity and the myth that of this identity should be the symptom, far from being a means for autonomy (as it was for Sorel), is tumed into its

\footnotetext{
${ }^{198}$ To my knowledge, Schmitt's usage of the concept of recognition, and, in particular, in relation to identity, has not yet been focused on. We cannot enter here a full discussion of the issue, but it is certainly one that deserves being further investigated.

${ }^{199}$ Carl Schmit's adhesion to Nazism is one of the most debated issues in the literature. Suffice is to note here that Schmitt's treatment of democracy and its compatibility with dictatorship reminds us that, as many
} 
opposite: identity or identification is the means for domination and, we can add, for the most annihilating form of domination.

Schmitt's treatment of identity and of the relationship between the latter and myth brings to light a series of conceptual problems linked to this use of the concept of identity. First, as we have seen, Schmitt considers myth as the symptom of an identity that is already given but, at the same time, one cannot but point to the fact that, as Sorel shows, and Schmitt also seems at certain points to recognise, ${ }^{200}$ myth is also the producer of identity. This leads to the problem of the continuity of identity, i.e. that which we can call the diachronic antinomy of identity: identity must exhibit continuity in time, it must be identical to itself in order to be "identity", but it is also the ever-changing product of the becoming.

Second, there is what we can call the synchronic dimension of this antinomy, which stems from the problem of the boundaries of identity. As we have seen in expressions such as "national identity" or "identity between rulers and the ruled", Schmitt combined "identity of singular individual beings with themselves", "their identity with each other", as well as "their identity with a tertium (e.g. the general will, the state, the nation)" and even "the identity of this tertium with itself in time". This brings forth the problem of the boundaries of identity and, in particular, the problem of the boundaries between personal and group identities.

Faced with the consequences of Schmitt's holistic use of the concept of identity one would be easily tempted to get rid of the concept altogether. Analogous problems emerge with some of the contemporary uses of the term "identity". Expressions such as "modern identity" (Taylor 1989), "national identity" (Smith 1991), or also the widespread "politics of identity" risk to lead to a holistic understanding of the concept of identity.

In the first place, it should be noted that even if we are now used to using the term "identity" without further qualifications, the concept always denotes a relation rather than a being: "identity" means that something "is identical" to something else. Therefore, beyond the widely debated "identity issue" and expressions such as "modern identity", "gender identity", "class identity" or "the Italian identity" there are possibly interrelated, but

authors have pointed out, Nazi-Fascism attempted to present itself as the saviour of democracy. For a discussion of Schmitt's theory from this point of view, see Wolin 1990.

${ }^{200}$ He seems to be aware of this when he analyses the way in which the creation through the work of literati and thinkers of an image of the bourgeois as an object of contempt has led to a class consciousness and the way in which this was supplanted by the working of national myth (Schmitt 1923: 17; 1926: 74-75). In 
fundamentally different, questions: the identity of the singular human being with herself/himself, the identity of different singular human beings with each other, the identity between the same singular human beings with themselves in time as well as the identity between them and a tertium (nation, the gender or another social group) and even the identity of this tertium with itself.

It is the possible conflation of all these different problems that renders the expression "identity" without further qualification so ambiguous. By simply rejecting the notion, though, one would still be left with the problems that the notion addresses. Therefore, a more promising strategy seems to be taking note of the ambiguity generated by these usages of the term and starting by distinguishing the different problems and issues that are here unified. In other words, we should move from the assumption that the term identity, as it comes out of these debates, fundamentally designates a "problematique" (Wagner 2002) rather than an "entity".

According to one view, the emergence of this problematique is intrinsically linked to the conditions of modernity. ${ }^{201}$ Taylor's influential "The Sources of the Self", whose subtitle is "The Making of Modern Identity", openly signals this relationship (Taylor 1989). Furthermore, while confronting the problem of personal identity, some authors have indeed noticed that it is under specifically modern conditions, i.e. in the moment when the singular human being is no longer assigned to a specific status by his birth and his position in the cosmos or the society, but is rather faced with an expanding myriad of possibilities, that the formation of his own identity becomes a problem (Melucci 2000).

This does not mean that personal and social identities did not exist before, or - better - that the issues to which the term refers did not exist. It only means that they were not problematic enough to be conceptualised, or that, at least, they did not appear as "problematic" as they appear to us now. In other words, we can say that the conditions of modernity rendered personal and social identity fundamentally problematic because they made it clear that our identities are always the instable result of "what we are", "what we have been" and "what we want to be". ${ }^{202}$ Modernity is by definition the "new epoch" (Neuzeit), the epoch that aspired to radically breaking with the past and thus it can

another crucial passage, after having asserted that a single individual can have the will of the people, he then adds "Everything depends on how the will of the people is formed" (Schmitt 1926: 27).

${ }_{201}$ On this point, see Wagner 2002.

${ }^{202}$ On this point, see Cerutti 1996. Cerutti insists on what he calls the normative and planning side (normativo $e$ progettuale) of any group identity: in identifying ourselves with a group we cannot leave aside 
transform identity into a "project": in an epoch when the "horizon of expectation" has supplanted the "space of experience", identity has to become a problem because it can no longer be seen as the mere deposit of the past. ${ }^{203}$

Hence, what we have called the diachronic antinomy of the identity problematique: identity, in whatever way we want to use this term, fundamentally refers to the idea of sameness, to an idem that remains the same in time by necessarily being at the same time always different (Friese 2002). Thus, identity is fundamentally a problem: it is the problem of the possible continuity of an idem in the becoming, i.e. of a possible idem in the difference between past, present and future.

Indeed, once one has signaled the dangers implicit in holistic uses of the concept of identity, one must also recognise that in all different cases - the identity of the self with itself, the identity of a self with others, or the identity of an abstract notion with itself in space and time - the problem of identity is always the problem of the idem. Otherwise stated, whatever qualification we add, the problem of identity is always the problem of the identity in difference, the antinomy of an idem that must be identical to itself by being at the same time different.

Clearly it is a different "difference" that is at stake each time in expressions such as "logical identity", "personal identity", or "group identity". All the same, it should be stressed that if the expression "identity" without futher qualifications has come to be widely employed, it is because it has been suggested that there are no clear boundaries between the various forms of identity: Schmitt's usage of the expression "identity between rulers and the ruled", or common expressions such as "national identity" or "politics of identity" all suggest more or less explicitly that the boundaries between different forms of identity have been challenged.

Therefore, whereas some authors, faced with the different forms of identity, simply liquidate the issue by saying that all these forms of identity have nothing to do with one another, ${ }^{204}$ one should take note rather that the problematique stems precisely from the problematic relationship between them: an object or a concept is identical to itself or to

\footnotetext{
"what we actually are", but neither "what we would like to be" nor "what we think we ought to be or do" (Cerutti 1996: 7)

${ }^{203} 1$ am here referring to the Koselleck's thesis as it is exposed in Vergangene Zukunft (Koselleck 1979).

204 Thus, Bilgrami for instance in his article on "Identity and identification: Philosophical aspects" (Bilgrami 2001) liquidates the issue of the different forms of identity by saying that the problem of the identity of "objects and events" must by treated by metaphysics and is not related to the problem of "national, ethnic and sexual identity". However, the problem although thrown out of the door comes back through the window, as it clearly emerges in his distinction between "objective" and "subjective" aspects of identity.
} 
something else in a different way from that in which a person can be said to be identical to itself or to another person, and the two, in turn, differ from the way in which a group can be said to be identical with itself in space and time. On the other hand, to distinguish between the two does not imply to deny possible overlap and convergences.

Let us begin from personal identity. What constitutes the idem in this case? In what sense and how can the self be said to be identical to itself in first place? Identity, it has been recently emphasised, is "a story of recognitions" (Pizzorno 2000). Ourselves, what "we are" is the result of our living in different circles of recognition and consists thus in a long series of recognitions by those who are part of these circles.

Different traditions, ranging from the philosophical reflections of Rousseau and Hegel to the interaction psychology of Mead, have recently been tumed to in order to point to the social dimension of the constitution of ourselves, i.e. to the fundamental fact that the ways in which we perceive of ourselves depend on the ways in which we are and have been perceived by relevant others (Taylor 1992, Honneth 1992) ${ }^{205}$ The concept of recognition points, thus, to the fact that our personal identity is inseparable from our social identity because it is the result of interaction with others.

The recourse to the concept of recognition does not imply though that personal identity coincides tout court with family-, gender-, national-, class- or any other form of group identity. The simplest reason why this is not true is that whereas in the case of personal identity the first vehicle of recognition is our body, in case of group identity, there is not a single visible body that is the object of recognition by both relevant others and by ourselves. ${ }^{206}$ The idea of a "social body" is clearly only a metaphor, and moreover, a much contested one. ${ }^{207}$

Thus, our identity is a story of recognition by others, but we interact with many others. Indeed, many theorists have, from different perspectives, underlined the multiplicity of identity: our identity, it has been claimed, is the result of the many different

\footnotetext{
${ }^{205}$ Notwithstanding the common reference to the concept of recognition, there are many differences between all of these approaches. In the first place, whereas Pizzomo has recourse to this concept from a sociological perspective, in order to explain how society and conflicts emerge (Pizzorno 2000), Honneth and Taylor have a clear normative intent. Honneth by following Hegel's Jena writings before the Phenomenology on the one hand and Mead's social psychology, explicitly aims at building up an ethics of conflict whose ultimate normative reference point remains however the singular human beings (Honneth 1992), whereas Taylor, who refers on the one hand to Rousseau and Hegel's dialectic of serf and master and to the Herderian ethic of authenticity on the other, applies the concept of recognition both to individuals as well as to social groups (Taylor 1992).

${ }^{206}$ For a critique of Pizzorno's neglect of the role of the body in the formation of identity, for instance, see Sparti 2000, as well as Pizzorno's answer in Pizzorno 2000.

${ }_{207}$ For a critique of the metaphors state-individuals, see for instace Bottici 2004.
} 
and sometimes contrasting roles and actions we perform in our life as well as of the way in which these generate dynamics of recognition. Still, if the word "identity" is to have a meaning whatsoever, if the concept of the "self" is to preserve its semantic core of "sameness" then there must be a unifying moment. The continuity of the body, perceived and recognised by others and by the self, is the first answer.

As A. Pizzomo points out, the fact that our identity is a story of multiple recognitions also implies that there is only one self that knows the whole story and can reconstruct it (Pizzorno 2000: 209). Our identity is not the chaotic juxtaposition of recognitions, because intertwined with these latter there is also self-recognition, a sort of self-attribution of identity. The self, thus, appears as a story of recognitions by others and by ourselves, because it is only the self that can reconstruct the whole story by narrating the recognitions that have been accumulating in space and time.

"Narrating in order to exist" (Melucci 2000) is the slogan that has be proposed for pointing out that the alternative is not between the Cartesian punctual "ego" and the dissolution of the idem in an eccentric identity. What creates an idem out of a more or less scattered set of recognitions is the possibility of a narrative. A self implies the possibility of telling a more or less coherent story and the unity of the self is the unity of a possible story. This, on the other hand, must be a story that encompasses an endless number of stories: that of a moving, living, interacting body; that of a mother, a daughter, a sister, a worker, a member of a polity, to mention only a few. And the concept of narrative has the advantage of pointing at the same time to "sameness" and the unavoidable "multiplicity" of identity.

Thus, if identity is the story of recognitions, then the loss of identity is the loss of the possibility of telling a story. According to one view, the pathologies of the self can be considered in terms of an interruption in a narrative or the loss of a coherent story (Ricoeur 1965). The therapeutic impact of psychoanalysis has consequently been identified, not in the removal of the cause of the "trauma", but rather in the possibility to rediscover a story. Disputes may arise, and have arisen, over the degree to which this rediscovery can be considered as a collective enterprise rather than an imposition by the therapist of a narrative upon the experience of the patient, but it seems as if there can be no definitive answer to this question.

On the other hand, what can be said is that the therapist does play a crucial role in the construction of the plot. The therapist is he who can help to rebuild a story by 
providing a narrative plot. In a letter to Einstein, Freud suggests that his theory is nothing but a great mythology (Freud 1932). In what sense can Freud's conception be considered a mythology? The therapeutic impact of Oedipus' complex lies in its power to generate story-plots: Oedipus's and Electra's stories are mythologems that can potentially provide a plot to an interrupted life experience. Therefore, a psychoanalytical therapy is successful not when the cause of the trauma is removed, which is impossible since an event has simply happened, but when it is inserted into a coherent narrative.

Notwithstanding the recent exponential interest in narrative, which has led to speaking of a crucial "narrative turn" in the human and social sciences (Aronsson 2001), the narrative core of the self is not a recent discovery. According to Foucault's discussion of the various technologies of the self, this discovery goes back at least as far as GreekRoman philosophy and Christianity: in one, in the form of confession, in the other, as philosophical dialogues and letters to friends. In both cases, the self is constructed through narrative practices (Foucault 1988). In modern societies, confessions have been integrated into more or less institutionalized practices such as interviewing, teaching, counselling and therapy, all of which covey what Foucault calls disciplining, i.e. normative patterns for what should be told and the ways in which it should be done (Foucault 1988).

Foucault's analysis of the technologies of the self brings us back to a crucial antinomy of identity: if identity is a story of recognition, then not only those who gave us past recognitions but also those who can influence our own construction of the plot dominate us. In other words, if our public and private selves are intimately linked to conversational practices and cannot be separated from them because it is through these practices that recognition, and thus the constitution of the self, takes place, what margin remains for autonomy? Identity as autonomy and identity as domination: this is perhaps the antinomy of identity that summarises all other possible antinomies: "identity as unity" versus "identity as plurality", "identity as choice" versus "identity as destiny" (Wagner 2002).

Two considerations, concerning respectively the diachronic and the synchronic dimensions of the antinomies of identity, can however be added. On the one hand, our identity is not just the story of past and present recognitions (both by others and by ourselves), but it is also the story of future and expected recognitions. These may or may not come, and our struggle for recognition may be more or less successful; but still the project and expectations of future recognitions is also constitutive of our own identity. At 
the same time, projects and expectations of future recognitions are also dependent on our present and past identities.

This, in turn, brings in the issue of the relationship between personal and group identities. In what sense can a social group, nation or class be said to be an idem? Either there can be an answer to this question or expressions such as "group identity", "social identity", etc. are, properly speaking, nonsense. Here the problem is not only that of the narrative synthesis among a more or less scattered set of recognitions. The problem is that there is not a "self" which can tell the whole story. There is not a body that is the object continuous in space and time of a set of recognitions and there is thus not a self that knows the whole story. Whereas the continuity of the self, and thus of the story that only s/he knows, can be guaranteed by the continuity of the body, in the case of the social group the idea of the body can at best be a contestable metaphor. The body with its precise contours is, in fact, the first vehicle of recognition by the other as well as for self-recognition, but in the case of group identities we do not have just one, but many living bodies with many different stories of recognitions to tell.

A social group, indeed, is a being of imagination in a different sense in which "this table' or "my self" are. ${ }^{208}$ Properly speaking, they are not beings of imagination, because there is not a single subject who has this faculty of imagination, but rather a being of the imaginary (Arnason 1994). In the case of social entities such as the nation, the class or the state, we are not dealing simply with abstract notions, but with socially constructed beings: it is because there are narrating bodies that behave as if such beings existed, that they actually exist. They are not, to use Schmitt's expression, a palpable reality. The recent explosion of literature on various aspects of "the construction of social realities" stems from a new emphasis on this fundamental insight.

If there is an idem that can unify the multiplicity of living, acting moving, narrating bodies, this, again, is a narrative, but it must be a narrative of a different sort: it must be a narrative that recognises that nobody can tell the whole story, and that maybe there is no story at all to tell. Any form of group identity adds a further dimension to the problematique of identity: the possibility to recompose, not just different stories, but also different narrating voices. The failure to do so results not simply in a "disturbance of

${ }^{208}$ Following the publication of Anderson's influential "Imagined Communities" and the growing interest in social constructivism there has been an exponential number of publications on the "construction" or "imagination" of social and political communities (Anderson 1983). Spinoza's theory of political myth, as we 
identity", but in the absence of a possible story, i.e. in the dissolution of a common identity.

How does myth relate to all this? The concept of the working of myth also implies the idea of plurality as well as that of its problematic nature. On the one hand, myth, as Schmitt points out, is intrinsically polytheistic: it is implicit in the concept of myth not only that there can be different variants of it, but also that there are many different and possible mythologems. Polytheism is what characterises myth but it also points, at the same time, to its danger: the plurality of stories may tum into the recognition that there is no common story to be told.

On the other hand, myth also implies the possibility of encompassing different stories in a common mythologem: different stories, stemming from different narrative voices, can be re-comprised in a single mythologem. Myth can, therefore, contribute to delineating the always problematic idem of any form of group identity. Group identities are in fact often defined in terms of a set of elements, such as principles, values, memories, symbols etc. that we recognise as common and sufficient for feeling as a "we". ${ }^{209}$ But what makes "a" single "set" out of a multiplicity of principles, values, memories, symbols? A common narrative seems to be the means of keeping together the variegated elements of any form of group identity. Myth, as narrative that provides significance, can also fundamentally contribute to this end.

Myth can, indeed, be one of the means through which a single narrative unifying all the variegated elements that constitute common identity come to be recognised and accepted by an intrinsic plurality of living, acting, narrating bodies. Myth is indeed a narrative that can coagulate and provide significance and significance, as we have seen, is always particularistic in the sense that what is significant for some people in given conditions might not be significant for other people in other conditions, as well as for the same people in different conditions.

Some authors have sustained that a group identity does not require a founding myth, which is seen as fundamentally deforming and thus as not criticisable, ${ }^{210}$ but only a founding narrative, i.e. "the memory, discussed and processed in public, of the processes, values and obligations thus maturated from which a political community or its new phase

have seen, contained some fundamental insights in this direction. What we need, though, is a transition, following Castoriadis, from "imagination" to "imaginary".

${ }^{209}$ See for instance Cerutti 1996: 6 . 
derives" (Cerutti 1996: 22). While not all identities are mythical in the sense that I can, for example, recognise my "italian idenity". without this being a source of significance to me, this does not means that all founding narratives cab be constitutive of identity. Indeed, there are many different stories that can be told about the "origins" of an idem without them necessarily being constitutive of identity. For a narrative to become constitutive of identity it has to be able to make sense for the subjects of that identity - and not all founding narratives can help in this direction. Furthermore, a narrative that makes sense does not need to be cast in the form of "memory", i.e. as narrative of the past, but it can well be a narrative of its future.

Political myths, on the other hand, are not necessarily deforming and hostile to critical discussion and they can therefore also be the non-pathological means for the shaping of common identities. In particular, as narratives that provide significance, they do not only make sense of experience, they also provide orientation and stimulation for action in the here and now. In this sense, they can be the producers of the common identities derived from this action. The general strike described by Sorel is not a simple narrative that provides meaning to the experience of the proletariat, but it is the narrative of its future action because it contains a determination to act: and it is from such an image of future common action that, according to Sorel, the proletariat can derive its identity.

This brings us back to the diachronic/synchronic dimensions of the antinomy of identity as well as to the problem of the relationship between political and other forms of identity. Myth has alternatively been seen as the result and the producer of identity. And identity, in turn, has been seen at the same time as a destiny and a choice. Still, as we have seen, if there is an idem, this must exhibit continuity. The working on myth can be considered as the working on a common narrative that provides significance and can thus link the present with the past and with the future. The working on myth, thus, does not solve nor promise a definitive solution to the fundamental tensions of identity, but rather fully addresses them.

A similar argument can be made for the synchronic dimension of the antinomies of identity: the working of myth, with its intrinsic plurality, can be seen as a means for sustaining the formation of group identities. The polytheism of myth, which, from the point of view of Schmitt's political theology, was a threat, can thus be seen as nothing but the

\footnotetext{
${ }^{210}$ On the relationship between myth and critique see Chapter 3, whereas on myth and the critique of political reason see Chapter 7 .
} 
reflex of the heterogeneity of group identity. Conversely, to assume that identity necessarily implies homogeneity means to assume the point of view of political theology, which is certainly empirically misleading as well as normatively problematic. All forms of group identity are the result of different stories and different narrative voices whose possible re-composition in a common mythology is never assured.

On the other hand, Sorel's example of the general strike shows that, from the point of view of a theory of political myth, there cannot be any sharp separation between cultural and political identity. The myth of the general strike is a specifically political myth because it addresses the need for a common action that affects the specifically political conditions in which this action takes place. The identity that the myth of the general strike contributes to shaping is indeed both cultural and political. What renders a myth specifically political, and therefore the identity that it can contribute to shape, is the way in which it interacts with the context and, thus, the specifically political conditions that are given each time.

These brief considerations do not pretend to be exhaustive. Manifestly, they open more questions than provide answers. They simply suggest that a theory of political myth can be very helpful in facing the problem of common political identities. In particular, a philosophy of political myth must adress the antinomies of identity because the identity that results from the working on political myth is and must remain a problematique.

A philosophy of political myth, indeed, does not entail a homogenising view of group identity. ${ }^{211}$ Rather, the view of group identity that the concept of working on myth presupposes clashes with the idea that group identities are self-like wholes. There are many variants of this idea today, but the idea of the "clash of civilisations" is perhaps the most striking. Civilisations and culturescan be said "to clash" with each other only if they can be said to "interact" with each other, to "hate" each other, to "perceive" each other in a certain way or in another. ${ }^{212}$ Expressions such as "nations today raise questions as to Who we are?", or even "in the world of global politics cultures interact with each other" (Huntington 1996: 21,43) imply attributing to cultural identities all the features of a self: raising questions, providing answers, interacting, and even hating and perceiving. Certainly

\footnotetext{
211 For instance Smith's ethno-nationalism, which considers myth as a fundamental component of national identities, also seems to endorse a homogenising view of national identities (Smith 1986, 1991, 1999).

However, it is only by conflating meaning and significance, on the one hand, and personal and group idenitity, on the other, that Smith can argue that since human beings need meaning, they also need to trace out their roots and genealogies and as they do it with their family origins so they do with communities and nation ( Smith 1999:60-61)
} 
these expressions are only metaphors, but the problem is that they are misleading ones. In particular, they can surreptitiously come to suggest that group identities could come close to exhibiting the same kind of coherence as self-identity. But in group identities there is not a single narrating body that can tell the whole story, and it can therefore always be the case that there is no common story at all.

Thus, the problem with Huntington's paradigm of the "clash of civilisations" is not only that he reduces social action to a unique category of determinations and motivations, i.e. culture (Terrier 2002: 141). Huntington explicitly claims that he merely aims to build a map of reality, which, like all kinds of maps, is necessarily reductive (Huntington 1996: 29). The problem is rather that the map that he wants to draw is empirically misleading, because it suggests the existence of clear-cut "boundaries", and normatively problematic, because it is based on the attribution to civilisations of the attributes of a self. ${ }^{213}$

The antinomies of identity, and in particular the attempt to solve them in a definitive way, has certainly helped in creating such a hypostatised view of identity. A certain degree of scepticism is thus necessary and we must never forget that beyond expressions such as "civilisational identities" (Huntington 1996) or also "national identity" (Smith 1991, 1999) there might be a conflation between the identity of individuals among each other, their identity with a tertium such as culture or nation, but also the identity of this tertium with itself in space and time. But the subjects of social identity are always singular human beings: they are human beings raising questions, providing answers, being the object and subject of the process of recognition. In other words, only singular human narrating bodies can tell the stories of common group identities and there is never the guarantee that all these stories can be reconciled in a single plot.

Thus, the paradigm of "multi-culturalism" should also raise suspicion. Social groups and nations can be the object of "recognition" only in a completely different way to which individuals are. They are not selves that can recognise each other on the basis of a body and of a single narrating voice. In his Politics of Recognition, Charles Taylor, following Herder, deals in a parallel way with identity and recognition of individuals and identity and recognitions of social groups (Taylor 1992). But to say with Hegel that it is only through a process of recognition by the others that the self can emerge does not mean to assume that

${ }^{212}$ Huntington, going against the German usage which distinguishes between "civilisation" (Zivilisation), as based on material factors, and "culture" (Kultur) as based on values, ideals, and other higher intellectual, artistic and moral qualities of a society, defines civilisations as cultural wholes (Huntington 1996: 41 and ff). 
social groups should be the object of a politics of recognition in as much as individuals should be. Axel Honneth and Alessandro. Pizzomo, for instance, moving from the same insight do not arrive at the same conclusion. ${ }^{214}$ To hold this conclusion means to consider cultures as self-like beings and overlook the fact that, for singular human beings, a politics of the recognition of single cultures thus understood may turn into into another form of universalism disguised as particularism.

In this way, the paradigm of multiculturalism, which theoretically derives from a critique of a solipsistic philosophy of the subject as pure abstract reason, risks turning into a form of solipsism on a larger scale, which is even more problematic than the solipsism of the subject it was meant to criticise. For instance, it has been suggested that this view of cultures as self-enclosed wholes could come to substitute that place once occupied by "race" in practices of discrimination: a multicultural politics of identity can result in a form of essentially flawed antiracism that, by endorsing a form of a cultural determinism of individual identity, tends to privilege cultures over individuals and can therefore lend itself to a politics of discrimination (Lentin 2004).

\footnotetext{
${ }^{213}$ In particular, on the fundamentally problematic character of any form of analogy between states and individuals, see Bottici 2004.

${ }^{214}$ In both these authors, the ultimate subject of recognition is the singular human being. Whereas Pizzorno has a more sociological approach. Honneth moves from the individual in order to construct an ethics that mediates between modern conceptions of freedom and morality and the ancient view of ethics (Honneth 1992, I:1).
} 


\section{POLITICAL MYTHS TODAY: THE EXTRAODINARY AND THE BANAL}

Political myth has often been associated with the extraordinary. Political myths, both when rejected by enlightened thinkers as regression into primitiveness or when acclaimed as symptoms of a great enthusiasm by their sympathisers, were most often seen as manifestations of the extraordinary. Thus, according to this view, political myths should have disappeared from modern politics, ruled as it is by an increasing rationalisation and bureaucratisation. In fact, this does not seem to be the case. Even in the world of organised modernity (Wagner 1994), it seems as if - to paraphrase Clifford Geertz - the mythical has not gone out of politics, however much the banal may have entered them (Geertz 1983: 143).

The suspicion emerges that it is precisely through the interplay of the extraordinary and the banal that the working of political myth can at best take place today. If this proves to be the case, then looking for the mythical only in the sites of the extraordinary, in the grand parades and blood rituals, one risks overlooking the actual sites for the working of political myth. Precisely by rendering banal the extraordinary and vice versa, political myth may come to operate within the ambit of that which is out of question, because it is either apparently irrelevant or too important to be questioned.

It should be remembered here that "banal" literally means "commonplace" in the sense of that which is used by the whole community. According to The Oxford English Dictionary, the term "banal" in the first place denoted something belonging to a compulsory feudal service, whereby for instace the tenants of a certain district were obliged to carry their corn to be ground at a certain mill and to be baked at a certain oven for the benefit of the lord; it is only from the intermediate sense of "open to the use of all 
the community" that the term comes to mean "commonplace, common, trite, trivial and petty" (Simpson, Weiner 1989, Vol.1: 147).

If banal means this, then the hypothesis seems legitimate that political myth operates by rendering banal, i.e. commonplace within a community, that which is prima facie extraordinary. On the other hand, it might also be the case that, particularly under contemporary conditions, political myth can also operate the other way round, i.e. by rendering extraordinary what is prima facie banal.

If the interplay of the extraordinary and the banal proves to be the privileged site for the working of political myth, then this latter assumes a much more sinister light than it ever has in the past. Whereas grand parades of fascist regimes in a sense rendered the role of political myths conspicuous, in the composed discourses of our politicians, there seems to be little place for the great enthusiasm that according to a romantic view should characterise political myth. This may in tum be the result of the fact that, under contemporary conditions, political myths have become more difficult to perceive.

The postmodern attacks on grand narratives, together with the prophecies of a world ruled by specialists without spirit, have from different sides contributed to obscuring the possible banality of political myth. By pointing at times towards the dangers of grand political narratives and at others towards their inevitable decline, both these approaches may have contributed to rendering us myopic in the face of the myths we live by (Midgley 2003). However, there is chance that the grand political narratives thrown out the door by post-metaphysical thought have re-entered through the window.

We have seen that, when analysing the technique of modern political myths, Ernest Cassirer observed that modern politicians fulfil the functions that, in traditional societies, were performed by the homo magus and homo divinans (Cassirer 1946: 288, 289). Our modern politicians, he observed, not only promise to cure all social evils, they also continually foretell the future: prophecy has become an essential element in the new technique of rulership, the most improbable and even impossible promises are made, the millennium is predicted over and over again - this, as we have seen, was his conclusion (Cassirer 1946: 289).

Now, if these remarks cannot fully explain why people need such prophecies, they can nevertheless provide some insights as to the forms that political myth can assume under the conditions of modernity. In particular, it seems as if the contemporary conditions of mediatisation and spectacularisation of politics (Edelman 1988) have 
indeed increased the potentiality of 'prophecy' as a technique of government. In other words, precisely under such new conditions, politicians are given unprecedented chances to "make the most improbable, even impossible promises". Our homines magi and divinantes might have refined their techniques of divination up to a point where they have lost any magical aspect, but while the techniques have changed deeply, the things themselves - to paraphrase Cassirer - have by no means vanished.

It is not only in the discourses of professional politicians that the working of political myth can be perceived. Again Cassirer's remarks contain helpful insights in this regard. Let us go back to the passage where he analyses the role played by prophecies:

"Curiously enough, - thus the passage continues - this new technique of divination first made its appearance not in German politics, but in German philosophy. In 1918 there appeared Oswald Spengler's Decline of the West. Perhaps never before had a philosophical book had such a sensational success. It was translated into almost every language and read by all sort or readers - philosophers and scientist, historians and politicians, students and scholars, tradesman and man in the street. What was the reason for this unprecedented success, what was the magic spell that this book exerted over its readers? It seems to be a paradox; but to my mind the cause of Spengler's success is to be sought rather in the title of his book than in its content. The title Der Untergang des Abendlandes was an electric spark that set the imagination of Spengler's readers aflame" (Cassirer 1946: 289).

The passage cannot but call the attention to the "sensational successes" of our epoch. Books such as Huntington's "The Clash of Civilisations" or Francis Fukuyama's "The End of History" also seem to owe their extraordinary success to their titles much more than to their content. Huntington's book is a mélange of the methods of political science, history and international relations, and nevertheless there are reasons to suspect that the power of "The Clash of Civilisations" rests more on its appeal to the imagination that on the rigour of his scientific arguments. The title of the book sets the imagination of its readers aflame no less than Spengler's did. The difference between the two is perhaps that, in the space of only a few years, the Clash of Civilisations turned into a selfrealising prophecy: while the "West" has not declined, "civilisations" appear indeed to have clashed.

Political myths, as we have seen, are not only the result of identity: they also create identity. They are not just the model of society, but also always the model for society (Lincoln 1989: 24). Flood has observed that political myths work both as 
cognitive schemata through which a present, past and future experience is organised and as practical schemata which orient and organise political action (Flood 1996). As Sorel also strongly emphasises, what is characteristic of political myths is that they do not exhaust themselves in contemplative images of the world; they also contain a determination to act (Sorel 1908). And this, as we have seen, is what, at the conceptual level, distinguishes them from purely historical narratives.

On the other hand, one does not have to look for titles that set the imagination of their readers aflame for seeing the working of political myth. According to one view, myth and theory regularly coexist and reinforce each other (Flood 1996: 105). Political myths are simply the working on a common narrative that provides significance to present, past and future experience: as such they are not opposed to rational theorising, as an enlightened view would pretend, but rather, they are quite often intermingled with it. "Political myth - Henry Tudor observed thirty years ago - supplies the theoretical argument with a concrete reference and a temporal perspective it would otherwise lack; on the other hand, the theoretical argument endows the myth with academic respectability and a certain timeless significance" (Tudor 1972: 126). Thus, for instance, Marx's theory of society is not in itself a myth. Nevertheless, when inserted into a context in which it can come to provide significance for the subjects operating in that context, it can work also as a political myth.

Far from constituting a dichotomy, myth and reason often reinforce each other. A political myth, though, in contrast to a theory, is rarely learned once and for all: rather it is more often apprehended through cumulative exposure (Chapter 9). If political myths, thus, have always been "the working on" a common narrative, it is perhaps the privilege of our time to have pushed the pervasiveness of this working to the extreme. Suspicious as we have become of any grand narratives, and thus of manifest political myths, we have developed political myths that, in comparison with those of the past, tend to exasperate their form of archipelago. Whereas the grand political myths of the past were as conspicuous as continents, today it is only by travelling from one island to the other that, most of the time, we apprehend them. The risk, thus, is that we might perceive only single islands, but no longer the whole archipelago.

On a basic level, this network is typical of any meaning that, to put it in Umberto Eco's terms, in always an unlimited network of references (Eco 1974). Each junction of the network is linked to the others by an unlimited series of references, so that 
its meanings cannot be separated from the position it occupies in the network. But political myths do not simply provide meanings: the archipelago constructed by the working of a political myth is held together by a particular type of connection - the being part of a narrative that has coagulated and thus makes significance for certain subjects at certain moments.

It is from the working of and on political myth that is also derived the peculiar relationship between political myths and those objects and images that convey them, and that Flood calls "icons" (Flood 1996). In modern societies, he observed, a photograph, a painting, a piece of sculpture, a carving, a cartoon, a poster, a mosaic, a collage among other things, can all represent an established political myth or a set of myths. The way in which this happens is in the form of a synecdoche: an icon is the "part" that stays for the "whole" of a political myth (Flood 1996: 167).

Hence is derived also the peculiar condensational capacity of political myth, i.e. its capacity to be conveyed through fragmentary references, images, watchwords, slogans, echoes, as stressed by Barthes in his Mythologies more that half a century ago (Barthes 1957). According to Barthes, today myths are second-order semiotic systems, i.e. the products of a form of meta-language in which pre-existing signs are appropriated and stripped of their original content, so that the contingent product of history is infused with a natural appearance (Barthes 1957). Myth, thus, has the task of giving a natural justification to a historical intention and rendering natural and therefore eternal the contingent. "This process, so Barthes wrote, is exactly that of bourgeois ideology. If our society is objectively the privileged field of mythical significations, it is because formally myth is the most appropriate instrument for the ideological inversion which defines this society" (Barthes 1957). ${ }^{215}$

Whereas Barthes rightly points to the increased condensational capacity of political myth in contemporary conditions, by defining myth as a second-order semiotic system which infuses historical products with a natural and thus apparently eternal appearance, he characterises myth as a form of false consciousness. As we have seen though, a more promising strategy is to make no assumption over the more or less mystifying contents of myth (Tudor 1972, Flood 1996, Lincoln 1989). Political myths are

\footnotetext{
${ }^{215}$ For a discussion of the concept of ideology see Chapter 9. It should be clear at this stage that such a polemical use of the concept of ideology is not very helpful towards an understanding of political myth.
} 
narratives that must make significance within always changing historical conditions that therefore take the form of a continual Arbeit am Mythos (Blumenberg 1979).

A rejection of grand narratives, on the one hand, and the emergence of new powerful technologies, on the other: both seem indeed to have rendered the working of political myth less and less perceivable, and therefore more subtle. The working of political myth has always been the working on significance and, as a consequence, political myths have always been difficult to analyse, precisely because the working of and on significance can take place at a more or less conscious level. Political myths are part of our basic components of everyday perception of politics and for this reason they remain unquestioned. They are not only that which we perceive about the world of politics, but rather the lens through which we perceive it (Bennett 1980). They are the basic assumptions of a society that are woven throughout everyday social discourses and practices: from dinner conversations to the lofty debates of political conventions (Bennett 1980).

However, if, to paraphrase Spinoza, all societies are and have in a sense been "mythical", what they differ in is the degree to which this mythical dimension can generate and is therefore compatible with further discussion. In other words, political myths can be the vectors of the project for autonomy, but in order to be so they must work as means for interrogation. The problem emerges, however, that under the contemporary conditions of a globalised spectacle (Edelman 1988) this becomes more and more difficult.

According to Bennett, it is because of the absence of formalised political ideologies in American politics that political myths tend to surreptitiously guide the whole process in which policies are made and public opinion formed (Bennett 1980: 167). Its systematic effect on public thinking, communication and action explains, according to Bennett, a number of the characteristics of American politics, including the narrow range of public debates, the restricted scope of political conflict, the tendency of political institutions to produce and implement policies that embody stabilising images of political order whether or not they have any impact on underlying social problems (Bennett 1980: 167).

In the process of growing up in contemporary mediatic societies, Bennett observes, most people encounter an overwhelming number of myths that gradually slip into their subconscious thinking (Bennett 1980). Young children are exposed to a battery 
of them through schools, parents, cartoons, films, advertisements, icons etc. These myths may recount the extraordinary vicissitudes of groups such as the Puritans, the Founding Fathers, the Slaves, the Westem Pioneers, the European Immigrants. But whether these groups and their heroes are black or white, rich or poor, great leaders or humble citizens, their dramatised experiences, according to Bennett, illustrate a remarkably similar set of virtues: in other words, their extraordinary adventures serve to transmit those models of conduct that are destined to uphold their future everyday banality. It is through these models of virtues - that which Spinoza called "exemplars of human nature" - that people first encounter models of life centred on free enterprise, industry, tolerance, perseverance and individualism (Bennett 1980).

Some of these myths, Bennett observes, point for instance to the causes of poverty and other social adversities and show how people overcome them; others teach the principles of politics, the standards of civility and the nature of society. The range of different myths available to make essentially similar points makes it possible for cultural perspectives to be transmitted in forms that are suited to the experiences of different social groups so that it is legitimate to assert that there is a clear body of myth at the basis of American society (Bennett 1980).

Neither could one object that these are cultural but not truly political myths: the concept of political myth precisely shows how problematic any sharp distinction between political versus cultural myths and identities can be. One cannot counterpoise "political" versus "cultural" identity as a "unity of political values and principles versus cultural diversity influencing their interpretation" (Cerutti 2003: 28) because what renders specifically "political" a set of values and principles is precisely the context in which they are set in the first place, and thus the way in which they are received and interpreted in everyday life.

There is, for instance, a whole range of literature showing how the working of apparently cultural myths alone can come to influence the specific political settings and conditions of a society, and thus also the commonsense of belonging to a community no less than the distribution of power and other limited resources (Bennett 1980, Yanarella and Sigelman 1988, Edelmann 1988). This literature has shown how, for instance in mass-oriented American 'Westerns', the myth of the Frontier addressed political issues such as the nature of society or the persisting problem of balancing the social need for law and the human desire for justice (Moeller 1980). Similarly, the problematic and 
undecided relationship between politics and sports fiction has been explored: according to one view, both when dealing with overtly political material and when not, works in the genre of sports fiction can be the site for the working of political myths. Among the narratives that have been able to coagulate significance, Shevory mentions the heroism of individual aspiration; the participation in community or rather the heroism of individuals equipped with extraordinary qualities, or the team as a utopian ideal (Shevory 1980).

Bennett also provides an illuminating example of the way in which political myths succeed in structuring political processes: their working is not only evident in the production of equally acceptable policy alternatives, but also in the generation of intolerance for political options that fall outside the range of the myth-sanctioned choices. The working of political myth is locatable in "what is not said" as much as in "what is overtly said". For instance, in the 1972 election, George McGovern elicited strong public rejection and confusion by proposing a guaranteed minimum income for every American. The total failure of the proposal is even more striking if compared with the success of Nixon's 1968 proposal for a guaranteed annual income.

The difference between the two, as Bennett observes, was not the amount of the stipend, which was the same, but the different terms in which the proposals were presented. Nixon put it in the mythically acceptable terms of a "Family Assistance Plan" and never mentioned the concept of a "minimum guaranteed income". McGovern's proposal, explicitly cast in the terms of a "guaranteed income", was, in contrast, unacceptable to a diffused mythical understanding of poverty that attributed it to individual failings on the part of the poor.

As Bennett further points out, the diffused belief in the individual causes of poverty is the result of the working of a political myth. Even if there is nothing "political" per se in the claim that the poor is poor because of its individual failures, and thus in the films, icons, and other fragmentary islands of this archipelago, it is clear that the context in which the working of myth operates and the way in which this myth is received and relaborated can come to render it crucially political. Furthermore, precisely because its working is not so easily locatable, dispersed and pervasive, it tends to remain out of question and, thus, to reinforce itself. According to Bennett, there is no policy success or failure that could contradict this myth today: if policies against poverty - most of them generally aimed at correcting "individual attitudes" - are seen to fail once, they are easily interpreted as proof of the incorrigibility of individuals (Bennett 1980: 172). 
Thus, from his analysis, Bennett concludes that the logic of mass communication tends to enhance the circularity of reasoning on social problems and political solutions: this circularity can also take the extreme form in which the failure of a political policy is regarded as a vindication of the assumptions and understandings on which it is based (Bennett 1980: 166). As Bennett concludes, the result of this is that "the popular significance of political outcomes may have less to do with their measurable social impact than with embodiment of enduring images of polity and society" (Bennett 1980: 166).

Among the factors that promote this circularity, two deserve further comment. In the first place, there is what has been called "the primacy effect" (Flood 1996: 87). This term has been coined in order to stress the power of a person's earliest perceptions of a phenomenon to function as the basis for generalisations, categorisations and expectations that are not easily or adequately revised in light of subsequent observation. Through a process of continual exposure that starts from childhood itself, the working of political myth assumes particularly insidious forms since it drastically reduces the possibility to perceive and thus dismiss it in favour of alternative cognitive and practical schemata.

The primacy effect is exacerbated under the contemporary conditions of a globalised spectacle. In a spectacular society, the possibilities of rendering extraordinary the banal, and vice versa, are enormously increased. Thus, for instance, one does not need certainly to read Huntington to begin to perceive the The Clash of Civilisations. This latter is continually put on the stage of our screens, and thus banalised, i.e. rendered commonplace through continual usage. One just needs to watch the news, children's cartoons or Hollywood films, or merely walk in the street: everywhere there are innumerable examples of the mediatic constructions of such a clash and of icons variously recalling it. People no longer see single individuals acting in one way or another, they actually see civilisations clashing with each other. In particular, the working of the political myth of "clash of civilisations", by providing the theory of the dangerousness of Islam with a concrete reference, as well as with an association with the emotional shock of September the $11^{\text {th }}$ is becoming one of more conspicuous political myths of our epoch (Geisser 2003). ${ }^{216}$

${ }^{216}$ Geisser analyses the ways in which the working of this myth in the French media, academic and political debates has contributed to the rise of a "new Islamophobia" (Geisser 2003) 
However, we do not need to look among bloody clashes for seeing the working of political myth. According to Bennett, one can see the working of political myth even in political routines such as elections (Bennett 1980). In his view, political elections and the spectacle that usually accompanies them in the USA, rather than being a moment for questioning a certain model of society, are the means through which a basic model of liberal democracy is reproduced: elections are its visible, acted and re-acted continuity (Bennett 1980).

And this brings us to our second consideration. If political myths are the models that a society or social group constructs of itself and for itself (Lincoln 1989: 24), rituals such as elections can be seen as one of the social routines through which these models are reproduced within society. Indeed, in virtue of their mere repetition, rituals powerfully contribute to reinforcing the circularity of political processes.

As we have seen, though, political myth and rituals are not coextensive concepts. ${ }^{217}$ Whereas myths have to change with the changing of the political conditions for which they must provide significance in order to be effective, rituals must remain unchanged for the same purpose. Rituals indeed represent the stability acted out and reenacted: by virtue of repetition they tend to deny the passage of time, the nature of change and the implicit extent of indeterminacy in social relations (Moore 1975).

Rituals, together with other icons, and various fragments of the archipelago, are the means through which the working of political myth can take place. As Spinoza pointed out when analysing the political myths of the nation of Israel, it is through social rituals recalling in everyday life the pact with God that this political myth works. The working of myth is rarely learned once and for all, but has to be internalised through cumulative exposure. For instance, the obsessive character of Jewish rituals, according to Spinoza, by virtue of the obsessive repetition of gestures - when eating, ploughing, sowing - had the precise function of implicitly annihilating the sense of individual autonomy: in their everyday gestures, the Hebrews had to confess that they were not their own masters, but entirely under the control of others (Spinoza 1670, V, 76). ${ }^{218}$ In particular, Spinoza observed, the strongest of all these rituals was circumcision: the inscription in the body itself of the alliance with God was such a strong means for the

\footnotetext{
${ }^{217}$ On the difference between myth and ritual in general see Chapter 6, whereas on the difference between political myth and ritual in particular see Chapter 9.

218 As we have seen, a similar point was made by Cassirer on the Nazi rituals: with their obsessive recurrence in everyday life they annihilated the sense of individual freedom (Cassirer 1946). On this point see Chapter 8.
} 
cohesion of the people that, Spinoza affirms, it was simply thanks to this ritual that the nation of Israel could survive for centuries without danger of dispersion (Spinoza 1670).

As we have seen, though, according to Spinoza, this does not mean that political myths, since they are often transmitted through rituals, are destined to inhibit social change. If political myths are models of a society and for a society and if these models are transmitted through social routines so that they are apprehended through cumulative exposure to them, how is it possible to account for social change? How can this circularity be opened? Under contemporary conditions, the problem seems destined to be even more insidious.

The enormous potentialities of the new mediatic technologies, their possible global range, the increasing role that they play in our everyday life, not to speak of the alarming possibilities opened by biopolitics, all of them could potentially render the working of myth incomparably more sinister than it has ever been in the past. The working of myth is no longer restricted to a few disparate, fragmentary appearances recalling each other, neither is it limited to a few political rituals: we live in a world made of icons, i.e. of potential conveyers of the working of myth. Moreover, the working of myth is rendered less and less accessible in the form of the "great narratives" of the past: the attacks against them, far from being liberating, have rendered the working of political myth more insidious whilst apparently "banal".

In facing the issue of how social change is possible, Maurice Bloch pointed out the difference between ritualised and non-ritualised discourses. For Bloch, writing thirty years ago, the problem was still how to account for social change moving from Durkheim's assumption that cognition is socially determined. His answer consisted in showing that, in fact, it is only "ritual" discourse that is moulded to the social structure. This, in his view, means that there are always terms available to social actors by which social order can be criticised: not all the terms are determined, in his view, by the social order (Bloch 1977).

Does this view still hold in the contemporary conditions of a globalised spectacle? On the one hand, we have seen that the working of what Bloch called ritualised discourses can be much more intrusive that in the past. We have also seen that the logic of mass communication tends to render the working of political myth much more insidious because, in a way, it neglects its own political character. There may be nothing overtly "political" per se in a Western, a sports fiction or any other sort of 
Hollywood film that does not openly deal with political material; but when it comes to the justification of certain policies over others, or even to the a priori denial of certain political options, then they do reveal their overtly political character.

Yet, as has been suggested, even in a sports fiction there can be germs of political criticism (Shevory 1980). Even in the contemporary condition of mass communication there can thus be a chance for the working of what Castoriadis called the "radical imagination" (Castoriadis 1975). However sinister the new conditions might render the working of political myth, there may still be space for the working of the critique. The slogan "another world is possible", which is the icon of a new possible political myth, is a symptom of the working of the radical imagination. The working of imagination is radical not only because it radically shapes our social imaginary, but also because it can create ex nihilo (not in nihilo or cum nihilo), and it can thus always potentially question its own products: imagination becomes radical when it becomes the means for interrogation.

To the question how is this possible, there is no general and definitive answer. Political myths, as well as political imagination in general, are destined to remain prey to the antinomies that we have seen in the working of identity: the working of political myth can mean unity and plurality, choice and destiny, the spaces for autonomy as well as for the most totalitarian of dominations. We do not need grand parades or blood rituals though to witness the working of political myths: they are a part of our banal political life.

The question of how questioning is possible is rendered even more complicated by the fact that the working of political myth is never "pure", but is always interwoven with other kinds of discourses. It is not only difficult to locate the working of political myth: it must also be distinguished from the other kinds of discourses in which it is most often wrapped up. Thus, for example, religious political myths are typically myths that aspire to providing an ultimate meaning and unique truth: this is true, for example, of the Jewish theocracy analysed by Spinoza (Spinoza 1670), as well as for the contemporary myth of martyrdom, against which Palestinian suicide attacks can be read (Larzillière 2003).

Scientific political myths, on the other hand, are those that present a narrative of events intermingled with chains of relationship causes and effects. Thus for example, the myth of the Aryan race that Cassirer analyses is based on a melange of narrative and 
scientific "findings", such as the biological superiority of the Aryan race (Rosenberg 1930, Cassirer 1946). Clearly, the two discourses bring different issues to the fore.

Finally, there are historical political myths. In this case, political myths are fused with historical narratives. Historical political myths are narratives that produce significance and that can come to affect political conditions. For instance, most national myths, such as the Italian Resistenza or the French Revolution, are derived from historical narratives (Smith 1986, 1991). In the case of historical narratives, the great advantage in respect to other forms of political myth is that there is a moment in which these narratives are given "visibility" since they can be put in the form of a "rationalised memory" (White 2000). In these cases, the working of myth can thus be more easily located, formalised and discussed.

Each of the types of political myth described above brings further considerations to the fore and, therefore, also calls for different tools of evaluation: the very possibility of an "ultimate meaning" in the face of a plurality of sacred stories, the correctness of scientific theory in respect to current paradigms, or the accuracy of the historical reconstruction in respect to current methods. Their possible fusion with political myths, on the other hand, points to their intrinsic plurality: the plurality of the "sacred stories", the probability of scientific findings as well as the never ending character of historical interpretation.

When the plurality of political myth is denied this is the sign that the instituted dimension of the social imaginary is denied. Political myths live out of history: they have to remain open to change because they must provide significance to changing circumstances. On the contrary, when political myths attempt at a closure of meaning, then no more working is possible and the myths in question cannot be revised, but only dismissed together with the political regimes that have produced them. Well known examples are the myth of Jewish theocracy, the myth of the Aryan race or the fascist myth of the Italian "Romanita". These are myths that, by attributing the origins of the social significations of a society to an extra-social source (Gods, heroes, ancestors), have covered up the instituted dimension of society, and thus subtracted it to the possibility of interrogation (Castoriadis 1988: 153).

This is the main reason why we should be sceptical in the face of all myths whose working can come to cover up the instituted dimension of society. Thus, for example, it is not in the story of the eponymous heroine Europa, recently revived from 
Greek mythology, that we should look for the mythical underpinnings of the construction of Europe (Passerini 2003). The risk is not only, as it has been observed, to close the meaning of the European construction into its problematic "Greek origins". As has been pointed out, the myth of Europa raped by the bull, however reinterpreted, remains a Greek myth that, under contemporary conditions, cannot but recall the exclusivist myth of a European inheritor of Greek civilisation: the working of this myth cannot but leave out all those who are "in but not of Europe" (Hall 2003). The myth of Europe raped by the Bull can be not only misleading - since there is no more reason to link the European Union to Ancient Greece than, let us say, to its Latin or even its Arab origins - but also normatively dangerous, because it can occult the instituted dimension of society.

Furthermore, as is always the case, by looking for the mythical among extraordinary stories of heroines and Gods, the risk is to become myopic towards the much more powerful and apparently banal myths that we live by. In the case of the European Union, at least two other political myths seem to be at work. One is the political myth of Europe as the land of freedom and welfare: the clearest sign of the working of this myth can perhaps be caught in the number of immigrants that are prepared to die at its borders. Secondly, there is the political myth that derives from the banal history of the European construction itself, first borm as an institution aimed to solve the historical conflicts between Germany and France over coal and steel, then developed into the European common market and later into the European Union. These, however, are still, to a great extent, myths to come. 


\section{BIBLIOGRAPHY}

Abbagnano, N. 1971, Dizionario di Filosofia, Torino, Utet

Adorno, F. 1961a La filosofia antica. I. La formazione del pensiero filosofico dalle origini a Platone VI-VI secolo a.C.. Milano, Feltrinelli

1961b, La filosofia antica. II. Filosofia, cultura, scuole tra Aristotele e Augusto IVII secolo a.C. Milano, Feltrinelli

Adomo, T.W., Horkheimer, M. (1944) 1969 Dialektik der Aufklärung. Philosophische Fragmente, Frankfurt a. M., Fisher Verlag

Aldrich, C. R. 1931, The primitive mind and modern civilisation, London, Kegan Paul

Anderson, B. (1983) 1991, Imagined Communities. Reflections on the Spread of Nationalism, London, Verso

Angehrn, E. 1996, Die Überwindung des Chaos. Zur Philosophie des Mythos, Frankfurt, Suhrkamp

Ankersmit, F. R., 2001, Historical Representation, Stanford, Stanford University Press

Anselmus, Saint, [1986], De veritate, French Trans., Corbin M. (sld.), Euvres d'Anselme de Cantorbéry, Paris, Ed. Du Cerf, Vol. 2

Apter, D.E. 1964 (ed) Ideology and Discontent, London, The Free Press of Glencoe

Aristotle [1970] Poetics, eng. trans. by W.H. Fyfe. F.M., Cambridge (MA), Harvard University Press, Loeb Classical Library, Vol. XXIII [1970] The Physics, engl. tr. Wicksteed, P.H., Cornford, F.M., Cambridge (MA), Harvard University Press, Loeb Classical Library, Vol. IV\&V

[1977], The Metaphysics, Engl. tr. Tredennick, M.A., Cambridge (MA), Harvard University Press, Loeb Classical Library, Vol. XVII-XVIII

- [1975] The "Art" of Rhetoric, Engl. tr. Freese, J.H. Cambridge (MA), Harvard University Press, Loeb Classical Library, Vol. XXII 
- [1974] Aristotle's categories. De Interpretatione, eng. tr. J. L. Ackrill, Oxford Clarendon

Amason, J.P. 1989 "The Imaginary Constitution of Modernity", in AAVV 1989. Autonomie et autotrasnformation de la société. La philosophie militante de Comelius Castoriadis, Genève, Libraire Droz, pp. 323-339

...--- 1994, "Reason, imagination, interpretation", in Robinson, G., Rundell, J., Rethinking Imagination: Culture and Creativity, London, Routledge, pp. 155-170

Arnason, J; Eisenstadt, S. and Wittrock, B. 2004 (eds) Axial Civilisations and World History, Leiden, Brill Publisher

Aron, R. (1955), 2002, L'opium des intellectuels, Paris, Hachette, Littérature; eng. trans. The Opium of the Intellectuals, New Brunswick, Transaction Publishers

Aronsson, K. 2001 'Narrative, Sociology of' Smelser and Baltes 2001 (eds), Volume 15, pp. 10286-10291

Arrington, R.L. and Glock, H.J. 1991 (eds) Wittgenstein's Philosophical Investigations:

Text and Context, London, Routledge

Assmann, J. 1997, Das kulturelle Gedächtnis. Schrift, Erinnerung und politische Identität in frühen Hochkulturen, München, Beck

------- 2000, Herrschaft und Heil: politische Theologie in Altaegypten, Israel und Europa, München, Carl Hanser

Astius, F. 1836, Lexicon Platonicum sive Vocum Platoniconum Index, Leipzig, Weidmann

Audi, R. (ed.) 1999, The Cambridge Dictionary of Philosophy, Cambridge, Cambridge University Press

Auerbach, E. (1938), Figura; italian trans. 1966 "Figura", in Studi su Dante, Milano, Feltrinelli

1946, Mimesis. Berne, Franke. Engl. tr.: 1953, Mimesis. The Representation of Reality in Western Literature, Princeton, Princeton University Press

Augustine, Saint, [1970], Confessiones, Engl. tr. Watts, W., London, Heinemann, Loeb Classical Library, 2. Vols

Bacon, F. (1627) 1963, Novum Organon, in The Works of Francis Bacon, London, Longman

Bartlett, R.C. 2000, "Introduction", in Bayle (1682), pp. xxiii-xlvii

Barthes, R. 1957, Mythologies, Paris, Seuil 
----- 1966, 1977, "Introduction to the structural analysis of narrative" in Image. Music.

Text, Fontana, Collins

1967, "Le discours de l'histoire" in Barthes 1984, Le Bruissement de la langue, Paris, Edition du Seuil; Eng. Trans "The Discourse of history", in The Rustle of Language, 1986, Oxford, Blackwell

Bayle, P. (1682) 2000, Pensées diverses sur la comète, engl. trans. Bartlett, R.C. Various Thoughts on the Occasion of a Comet, Albany, State University of New York Press

Bell, D. 1960, The End of Ideology: On Exhaustion of Political Ideas in the Fifties, London, The Free Press of Glencoe

Bennett, W.L. 1980, "Myth, Ritual, and Political Control", Journal of Communication, 30, pp. 166-179

Bilgrami, A. 2001, "Identity and Identification: Philosophical Aspects", in Smelser and Baltes 2001 (Eds), Volume 11, pp. 7148-7154

Bisan Centre for Research and Development, 2001, "Role of NGOs in Building Palestinian Civil Society", Ramallah

Bloch, M. 1924, Le rois thaumaturges: Etude sur le caractère sumaturel attribué à la puissance royale, particulièrement en France et en Angleterre, Strasbourg, Librairie Istra

Bloch, M. 1977, "The Past and the Present in the Present" in Man, 12, 2, pp. 278-282

Blumenberg, H. 1966, Die Legitimität der Neuzeit, Frankfurt a. M., Suhrkamp 1971, "Wirklichkeitsbegriff und Wirkungspotential des Mythos", in Fuhrmann (ed.), Terror und Spiel. Probleme der Mythenrezeption, München, Fink Verlag, pp. 11-66; Italian Translation, Il futuro del mito, 2002, Milano, Medusa

-----1979, Arbeit am Mythos, Frankfurt a. M., Suhrkamp

Bobbio, N. Matteucci, N. and Pasquino, G. (1983), 1990, (eds) Dizionario di Politica, Torino, Utet

Bohrer, K.H. 1983 (ed.), Mythos und Moderne. Begriff und Bild einer Rekonstruktion, Frankfurt a. M., Suhrkamp

Bonitz, H. 1955, Index Aristotelicus, Secunda Editio, Graz, Akademische Druck-U. Verlagsanstalt

Bottici, C. 2004, Governare gli uomini, govemare gli stati: una possibile analogia?, Pisa, ETS (forthcoming) 
Boudon, R. 1999, "Local vs General Ideologies: a normal ingredient of modern political life", in Journal of Political Ideologies, 4, 2, pp.141-161

Bouveresse, J. 1982, “L'animal cérémoniel: Wittgenstein et l'anthropologie”, in Wittgenstein 1967b, French Translation, pp.41-124

Brandwood, L. 1976, A Word Index to Plato, Leeds, W.S. Maney \& Son Ltd

Braudel, F. 1950, "The situation of history in 1950", in Braudel 1980, On history, London, Weidenfeld and Nicolson

Brunner, O. Conze, W. and Koselleck, R. (1974-1997), Geschichtliche Grundbegriffe: Historisches Lexikon zur politischen-sozialen Sprache in Deutschland, Stuttgart, Klett

Burnet, J. 1920, Early Greek Philosophy, London, A\&C Black

Bultmann, R. 1962, "Zum Problem der Entmythologisierung", in Il problema della demitizzazione. Atti del convegno indetto dal Centro Intemazionale di Studi Umanistici e dall'Istituto di Studi Filosoofici, Roma, Archivio di Filosofia.

Bultmann, R and Jaspers, K. 1954, Die Frage der Entmythologisierung, München, Piper Verlag

Callimachus, [1949] 1996, Inni, Epigrammi, Ecale, Aitia, Giambi e altri frammenti, Edited by G.B. D'Alessio, Milano, Biblioteca Universale Rizzoli

Cantelli, G.1986, Mente. Corpo. Linguaggio. Saggio sull'interpretazione vichiana del mito, Firenze, Sansoni

Cassirer, E. (1925) 1985, Philosophie der symbolischen Formen, Darmstadt, Wissenschaftliche Buchgesellschaft -(1932) Die Philosophie der Aufklärung, Tübingen, Mohr; eng. trans Koelln, C.A. and Pettergrove, J.P. The philosophy of Enlightenment, Princeton, Princeton University Press

-- (1946) 1973, The Myth of the State, New Haven, Yale University Press

(1968) An essay on man-an Introduction to a philosophy of human culture, New Haven, Yale University Press

Castoriadis, C. 1975, L'institution imaginaire de la société, Paris, Seuil

--_-_- 1982, "Institution de la société et religion" in Castoriadis 1986, pp.455-481

1986, Domaines de l'homme. Le carrefour du labyrinthe, Paris, Seuil

1988, "Power, Politics, Autonomy", in 1991, Philosophy, Politics, Autonomy Essays in political philosophy, Oxford, Oxford University Press, pp. 143-175 
1994, "Radical Imagination and the Social Instituting Imaginary", in 1997, The Castoriadis Reader, Oxford, Blackwell, pp. 319-338

Cavell, S. 1979, The Claim of Reason: Wittgenstein, Scepticism, Morality and Tragedy, Oxford, Clarendon Press

Cazes, B. 2001, "Utopias: Social", in Smelser and Baltes 2001 (eds), Volume 24, pp.16123-16127

Cerutti, F. 1996, "Identità e politica" in Cerutti 1996 (ed) Identità e politica, Bari, Laterza, pp. $5-43$

2003, "A Political Identity of the Europeans", Thesis Eleven, 72, London, Sage, pp. $26-45$

Cerutti, F., Rudolph, E. (eds.) 2001, A soul for Europe, Leuven, Peeters

Chantraine, P. 1984, Dictionnaire Etymologique de la langue Grecque. Histoire des Mots, Paris, Edition Klincksieck

Churchill, J. 1989, "If a Lion Could Talk...", in Philosophical Investigations, 12, 4, pp. 308-324

Clack, B.R. 1999, Wittgenstein, Frazer and Religion, London, Macmillan

Cohan, S. and Shires, L. 1988, Telling Stories. A theoretical analysis of narrative fiction, New York and London, Routledge

Cohen, A.P. (1985) 1989, The Symbolic Construction of Community, London, Routlegde

Cohn, N. 1970, The Pursuit of the Millennium, London, Paladin

Cole, T. 1983, "Archaic Truth", Quademi Urbinati di Cultura Classica, 13, pp. 7-28

Colli, G. 1975, La nascita della filosofia, Milano, Adelphi

1977, La sapienza greca I: Dioniso, Apollo Eleusi, Orfeo, Museo, Iperborei, Enigma, Milano, Adelphi

1978a La sapienza greca II: Epimenide, Ferecide, Talete, Anassimandro, Anassimene, Onomacrito, Milano, Adelphi 1978b, La sapienza greca III : Eraclito, Milano, Adelphi

Cornford, F.M. 1952, Principium Sapientiae. The origins of Greek philosophical thought, Cambridge, Cambridge University Press

Cosmas Indicopleustes, [1897], Topographia Christiana, Engl. tr. McCrindle, J.W., The Christian topography of Cosmas, an Egyptian Monk, London, Hakluyt Society

Coulter, J. 1999, “Discourse and Mind”, in Human Studies, 22, pp.163-181 
Courtine, J-F. 1992a, "Realitas" in Gabriel, G., Gründer, K., Ritter, J. (eds.) 1971-, Bd. VII, pp. 178-185

- 1992b, "Realität/Idealität" in Gabriel, G., Gründer, K., Ritter, J. (eds.) 1971, Bd. VII, pp. 185-193

Dante, A. [1988], La Divina Commedia. Inferno. Bosco, U. and Reggio, G. (eds), Firenze, Le Monnier

- [1989] La Divina Commedia. Purgatorio. Bosco, U. and Reggio, G. (eds), Firenze, Le Monnier

- [1989] La Divina Commedia. Paradiso. Bosco, U. and Reggio, G. (eds), Firenze, Le Monnier

[1995] Epistola a cangrande, Cecchini, E. (ed), Firenze, Giunti

Das, V. 1998, "Wittgenstein and Anthropology" in Annual Review of Anthropology, 27, pp.171-195

Delatte, L., Rutten C., Govaerts S., Denooz J. 1984, Aristoteles Metaphisica. Index Verborum. Listes de Fréquence, Hildesheim, Olms-Weidmann

Deleuze, G. 1962, Nietzsche et la philosophie, Paris, Presses Universitaires de France

Della Porta, D., Greco, M. and Szakolczai, A. (2000) Identità, scambio, riconoscimento.

Saggi in onore di Alessandro Pizzomo. Con una risposta e un saggio autobiografico di Alessandro Pizzomo, Bari, Laterza

Dieckhoff, A. and Leveau, R. 2003 (eds.) Israéliens et Palestiniens: la guerre en partage, Paris, Éditions Balland

Dierse, U. 1976, "Ideologie", in Gabriel, G., Gründer, K., Ritter, J. (eds.) 1971, Bd. IV, pp. 157-185

Denooz, J. 1988, Aristote « Poetica ». Index Verborum. Liste de fréquence, Liege, Centre Informatique de Philosophie et Lettres

Descartes, R. (1637) 1973, Discours de la Méthode, Paris, Libraire Philosophique Vrin (1641) 1973, Meditationes de prima philosophia, Paris, Libraire Philosophique Vrin

Detienne, M. 1967, La Maîtres de la vérité dans la Grèce archä̈que, Paris, Maspéro 1981, L'invention de la mythologie, Paris, Engl. tr. The Invention of Mythology, Chicago

Diels, H., Kranz, W. (1938) 1951, Fragmente der Vorsokratiker, Zürich, Weidmannsche Verlagsbuchhandlung 
Dierse, U. 1976, “Ideologie” in Gabriel, G., Gründer, K., Ritter, J. (1971- ), Bd. 4, pp. 157186

Döner, A. 1996, Politischer Mythos und symbolische Politik, Reinbeck, Rowolt

Dörrie, H. 1972, Der Mythos und sein Funktion in der antiken Philosophie, Innsbruck, Innsbrucker Beiträge zur Kulturwissenschaft

Dubois, M. 2001 "Ideology, Sociology of" in Smelser and Baltes 2001 (eds) volume 11, pp. 7177-7182

Duhem, P. 1965, Le système du monde: histoire des doctrines cosmologiques de Platon à Copernic, Paris, A. Herman

Eagleton, T. 1991, Ideology: an Introduction, London, Verso

Eco, U. 1974, Trattato di semiotica generale, Milano, Bompiani; eng. trans. 1976 A Theory of Semiotics, Bloomington, Indiana University Press

Edelmann, M. 1976 The Symbolic Uses of Politics, Urbana, University of Illinois Press

-1.-1967, "Myth, Metaphors and Political Conformity", Psychiatry, 30, 3, pp.217-28

---.-- 1988, Constructing the Political Spectacle, Chicago, University of Chicago Press

Eliade, M. 1954, The Myth of the Eternal Return, or Cosmos and History, Princeton, Princeton University Press

-.----1957, Mythes, rêves et mystères, Paris, Gallimard

Evans-Pritchard, E.E. 1948, The Divine Kingship of the Shilluk of Nilotic Sudan, Cambridge, Cambridge University Press

Finnegan, R. 1988, Literacy and Orality, Studies in the Technology of Communication, Oxford, Blackwell

Fisch, J. 1992, “Zivilisation, Kultur”, in Brunner, Conze, Koselleck (eds), 1974-1997, Bd 7:679-774

Flood, C.G 1996, Political Myth. A theoretical Introduction, New York, Garland

Foucault, M. 1988 “Technologies of the Self", in Martin, Gutman, Hutton (eds) 1988

Frandsen, S.B. 2000 "Italian Fascism and Roman Heritage: The Third Rome of Mussolini" in Stråth (ed) 2000, pp. 157-169

Frank, M. 1982, Der kommende Gott. Vorlesungen über die Neue Mythologie, Suhrkamp, Frankfurt a. M.

Frazer, J.G. $\left(1890^{1}, 1911-15^{2}\right)$ 1922, The Golden Bough, a Study in Magic and Religion, London, Macmillan 
Freeden, M. 2001, "Ideology: Political Aspects", in Smelser and Baltes (eds) 2001, volume 11, pp.7175- 7177

Freeman, K. 1966, The Pre-Socratic Philosophers. A Companion to Diels' Fragmente der Vorsokratiker, Oxford, Blackwell

Freud, S (1899), Die Traumdeutung, in 1941-1968, Gesammelte Werke, Frankfurt a. M., Fischer, Bd. II-III

(1913), Totem und Tabu, in 1941-1968, Gesammelte Werke, Frankfurt a. M., Fischer, Bd. IX

----- (1921), Massenpsychologie und Ich-Analyse, in 1941-1968, Gesammelte Werke, Frankfurt a. M., Fischer, Bd. XV

----- (1929) Das Unbehagen in der Kultur, in 1941-1968, Gesammelte Werke, Frankfurt

a. M., Fischer, Bd. XIV

(1917-1932) Vorlesungen zur Einführung in die Psychoanalyse- Neue Folge, in 1941-1968, Gesammelte Werke, Frankfurt a. M., Fischer, Bd. XI

-...--_(1932) Warum Krieg? Gesammelte Werke, Frankfurt a. M., Fischer, Bd. XVI, pp13-27

Friedman, J. 1992, "Myth, History, and Political Identity", in Cultural Anthropology, 7, 2, pp.194-210

Friese, H. 2001, "Imagination: History of the concept", in Smelser and Baltes (eds) 2001, Volume 11,pp. 7197-7201

---.-- 2002 (ed) Identities. Time, Difference, and Boundaries, Oxford, Berghahn Books ------ 2002, "Introduction" in Friese 2002 (ed) pp. 1-12

Friese, H. and Wagner, P. 2002 "Survey Article: The Nascent Political Philosophy of the European Polity", in Joumal of Political Philosophy, 10, 3: 342-364

Fuhrmann, M. (ed) 1971, Terror und Spiel. Probleme der Mythenrezeption, München, Fink Gabriel, G., Gründer, K., Ritter, J. (1971- )(eds.) Historisches Wörterbuch der Philosophie, Bd. I-XI, Darmstadt, Wissenschaftliche Buchgesellschaft

Gadamer, H.G. (1960) 1975, "Wahrheit und Methode", in Gesammelte Werke, Tübingen, Mohr, Bd. I; Engl. tr. 1988, Truth and Method, London, Sheed and Ward (1981a) 1993 "Mythos und Logos", in Gesammelte Werke, Bd. VIII; Tübingen, Mohr, pp170-188 (1981b) 1993 "Mythologie und Offenbarungsreligion", in Gesammelte Werke, Bd. VIII, Tübingen, Mohr 
(1981c) 1993 “Der Mythos im Zeitalter der Wissenschaft", in Gesammelte Werke,

Bd. VIII, Tübingen, Mohr

Galilei, G. (1609), 1953 "Nuncius Sidereus", in Opere di Galileo Galilei, Firenze, Ricciardi

(1613) 1995, "Lettera a Don Benedetto Castelli", in Galilei. Le Lettere Copemicane. Roma. Armando Editore

(1623) 1965, Il Saggiatore, Milano, Feltrinelli

Geertz, C. 1964 "Ideology as a Cultural System" in Apter (ed) pp47-76

1973 , Interpretation of Cultures, New York, Basic Books

1983, Local Knowledge, New York, Basic Books

1995, After the Fact, Two Countries, Four Decades, One Anthropologist, Cambridge (MA), Harvard University Press

2000, Available Light. Anthropological Reflections on Philosophical Topics,

Princeton, Princeton University Press

Gehlen, A. (1950) 1997, Der Mensch: seine Natur und eine Stellung in der Welt, Wiesbaden, Quelle und Meyer, eng. trans. 1988 Man, his Nature and Place in the World, New York, Columbia University Press

- (1956) 1994, Urmensch und Spätkultur: philosophische Ergebnisse und Aussagen,

Wiesbaden, Aula Verlag; 1980 Man in the Age of Technology, New York, Columbia University Press

Geiser, K. 1963, Platons ungeschriebene Lehre, Stuttgart, E. Klett Verlag

Geisser, V. 2003, La nouvelle islamophobie, Paris, Editions La Découverte

Gliozzi, G. 1977, Adamo e il nuovo mondo. La nascita dell'antropologia come ideologia coloniale dalle genealogie bibliche alle teorie razziali (1500-1700), Firenze, La Nuova Italia

Gockel, H. 1981, Mythos und Poesie. Zum Mythosbegriff in Aufklänung und Frühromantik, Frankfurt a. M., Klostermann

Goody, J. 1977, The Domestication of the Savage Mind, Cambridge, Cambridge University Press

1986, The Logic of Writing and the Organisation of Society, Cambridge University Press

Goody, J., Watt, I. 1968, "The Consequences of Literacy" in Goody (ed), Literacy in Traditional Societies, Cambridge, Cambridge University Press, pp. 27-68 
Gramsci, A. [1975] Quademi del carcere. Edizione critica dell'Istituto Gramsci, Torino, Einaudi

Grünepütt, K. 1992, "Realität der Aussenwelt" in Gabriel, G., Gründer, K, Ritter, J. (eds.)

Historisches Wörterbuch der Philosophie, Bd. VII, Darmstadt, Wissenschaftliche Buchgesellschaft, pp.206-211

Habermas, 1981, Theorie des kommunikativen Handels, Frankfurt a. M., Suhrkamp 1985, Der philosophische Diskurs der Moderne. Zwölf Vorlesungen, Frankfurt a.

M., Suhrkamp

1992, Faktizität und Geltung. Beiträge zur Diskurstheorie des Rechts and des demokratischen Rechtstaat, Frankfurt a. M., Suhrkamp

-...-... 1996a, Die Einbeziehungen des Anderen. Studien zur politischen Theorie, Frankfurt a. M., Suhrkamp

- 1996b, Kampf um Anerkennung im demokratischen Rechtstaat, Frankfurt a. M., Suhrkamp

1998, Die Postnationale Konstellation. Politische Essays, Frankfurt a. M., Suhrkamp

Havelock, E.A. 1963, Preface to Plato, Oxford, Oxford University Press 1983, "The Linguistic Task of Presocratics", in Robb, K. (ed.), Language and Thought in Early Greek Philosophy, La Salle, Hegeler Institute

1986, The Muse Learns to Write, Reflections on Orality and Literacy from the antiquity to the Present, New Haven, Yale University Press

Hegel, G.W.F. (1807) 1971, Phänomenologie des Geistes, in G.W.F Hegel. Werke in Zwanzig Bänden, BD. III, Frankfurt a. M., Suhrkamp - (1821) 1971 Grundlinien der Philosophie des Rechts, in G.W.F Hegel. Werke in Zwanzig Bänden, BD VII, Frankfurt a. M., Suhrkamp

-...-- $\left(1831^{3}\right)$ 1971, Enzyklopädie der Philosophischen Wissenschaften, in G.W.F Hegel. Werke in Zwanzig Bänden, BD VIII, IX, X, Frankfurt a. M., Suhrkamp

[1971] Vorlesungen über die Geschichte der Philosophie, in G.W.F Hegel. Werke in Zwanzig Bänden, BD XVIII-XX, Frankfurt a. M., Suhrkamp

[1971], Vorlesungen über die Philosophie der Geschichte, in G.W.F Hegel. Werke in Zwanzig Bänden, BD XII, Frankfurt a. M., Suhrkamp 
Hegel, G.W.F, Hölderlin, F., Schelling, F.W.J. (1796) 1971, Das älteste Systemprogramm des deutschen Idealismus, in G.W.F. Hegel. Werke in Zwanzig Bänden, I Bd, Frankfurt a. M., Suhrkamp, pp.234-237

Heidegger, M. (1927) 1993, Sein und Zeit, Tübingen, Max Niemeyer Verlag,; Engl. tr. Being and Time, Oxford, Blackwell

(1988) Vom Wesen der Wahrheit: zu Platons Höhlengleichnis und Theätet, in Gesamtausgabe, Frankfurt am Main, Klostermann, BD 34; Engl. trans. 2002 The Essence of Truth: On Plato's Cave Allegory and Theaetetus, London, Continuum

Henry, B. 1986, Libertà e mito in Cassirer, Napoli, ESI

2000, Mito e identità. Contesti di tolleranza, ETS, Pisa

2001, The role of symbols for symbols for European political identity - Political

Identity as a myth?, in Cerutti and Rudolph, (ed), 2001 A soul for Europe, Peeters, Leuven

Herodotus, [1920], Historiae, Engl. tr. Godley, A.D., London, Heinemann, Loeb Classical Library, 4 Vol.

Hesiod, [1977], Theogony, in Hesiod. The Homeric Hymns and Homerica, Engl. tr. Evelyn-White, H.G. London, Heinemann, Loeb Classical Library

Hick, J. (ed.) 1977, The myth of God incamate, London, SCM Press 1982 God has many names, Philadelphia, Westminster Press

Hippler, T. 2000, Spinoza on Historical Myth, in Stråth, B. (ed.), Myth and Memory in the Construction of the community, Bruxelles, Peter Lang

Hirsch, W. 1971, Platons Weg zum Mythos, Berlin, De Gruyter

Hobbes, T. (1650), 1994, The Elements of law, natural and political, Oxford, Oxford University Press

-.-.- (1651) 1985, Leviathan, London, Penguin

Hobsbawm, E.J. 1963, Primitive Rebels: Studies in Archaic Forms of Social Movement in the $19^{\text {th }}$ and $20^{\text {th }}$ Centuries, Manchester, Manchester University Press (1990) 1992, Nations and nationalism since 1780, Cambridge, Cambridge University Press

Hobsbawm, E.J., Ranger, T. 1983, The Invention of Tradition, Cambridge, Cambridge University Press

Hölderlin, F. [1981] Sämtliche Werke und Briefe, München, Hanser 
Hoffmann, F. et al., 1992, "Realismus" in Gabriel, G., Gründer, K., Ritter, J. (eds.) Historisches Wörterbuch der Philosophie, Bd. VII, Darmstadt, Wissenschaftliche Buchgesellschaft, pp. 148-170

Homer, [1995], Odyssey, Engl. tr. Murray, A.T., Dimock. G.E., Cambridge (MA), Harvard University Press, Loeb Classical Library, 2 Vol.

-..-.- [1978], The Iliad, Engl. tr. Murray, A.T., Cambridge (MA), Harvard University Press, Loeb Classical Library, 2 Vol.

Honneth, A. 1992, Kampf um Anerkennung, Frankfurt a. M., Suhrkamp; Engl. tr. 1995, The Struggle for recognition. The Moral Grammar of Social Conflicts, Cambridge, Polity Press

Hübner, K. 1985, Die Wahrheit des Mythos, München, Beck

---- 1994, Die zweite Schöpfung. Das Wirkliche in Kunst und Musik, München, Beck

Hume, D., (1739) 1985, A Treatise of Human Nature: Being an Attempt to Introduce the Experimental Method of Reasoning into Moral Subjects, London, Penguin

Huntington, S. P. 1996 The Clash of Civilisations and the Remaking of World Order, New York, Simon and Schuster

Husserl, E. (1901) 1922, Logische Untersuchungen, in Gesammelte Schriften, 1992, Hamburg, Meier, Bd. II-III-IV

(1912) 1952, Idee zu einer reinen Phänomenologie, in Gesammelte Schriften, 1992, Hamburg, Meier, Bd. V

[1950] Cartesianische Meditationen, in Gesammelte Schriften, 1992, Hamburg, Meier, Bd. VIII

(1935) "Die Philosophie in der Krisis der europäischen Menschheit" ; Engl. trans.

"Philosophy and the Crisis of European Humanity. The Vienna lecture", in Husserl 1954

[1954], Die Krisis der europäischer Wissenschaften und die transzendentale Phänomenologie, in Gesammelte Schriften, 1992, Hamburg, Meier, Bd. VIII; eng. trans. The Crisis of the European Sciences and Transcendental Phenomenology, Evanston, NorthWestern University Press

Iser, W. 1976, Akt des Lesens, München, Fink; eng. Trans. 1978 The Act of Reading, Baltimore, John Hopkins University Press

Jamme, C. 1991, Einführung in die Philosophie des Mythos, Darmstadt, Wissenschaftliche Buchgesellschaft 
1999, "Gott an hat ein Gewand". Grenzen und Perspektiven philosophischer

Mythos-Theorien der Gegenwart, Frankfurt a. M., Suhrkamp

Jenkins, K. (ed.) 1997, The Postmodern History Reader, London, Routledge

Jenkins, R, 1996, Social Identity, London, Routledge

Jost, J.T. 1995, "Towards a Wittgensteinian Social Psychology of Human Development" in

Theory and Psychology, 5, 1, pp.5-25

Joyce, J. [1957] Letters of James Joyce, Ellmann R. (ed), London, Faber \& Faber

Jung, C.G. (1939), Das symbolische Leben; Engl. tr. The symbolic life, in The symbolic

Life. The collected Works of C.G. Jung, Vol. 8, Princeton, Princeton University Press

- (1954), "Über die Archetypen des kollektiven Unbewussten". In Von den Wurzel

des Bewusstseins, Zürich, Rascher; Engl. tr. Archetypes of the Collective

Unconscious, in The archetypes and the Collective Unconscious. The collected

Works of C.G. Jung, Vol. 9, Princeton, Princeton University Press

Kahn, C.H. 1973, The verb "be" in Ancient Greek, Dordrecht, D. Reidel Publisher

Kaiser El-Safti, M. 1992, "Realität, formale/objektive" in Gabriel, G., Gründer, K., Ritter,

J. (eds.) Historisches Wörterbuch der Philosophie, Bd. VII, Darmstadt, Wissenschaftliche Buchgesellschaft, pp.194-206

Kant, I. $\left(1781^{l} 1787^{2}\right)$ 1968, Kritik der reinen Vermunft, in Kants Werke, hrsg. Königlich PreuBischen Akademie der Wissenschaft (AA), Berlin, 1902, Walter de Gruyter Bände III-IV; Engl. tr. Critique of Pure Reason, in 1998, The Cambridge Edition of the Works of Immanuel Kant, Cambridge, Cambridge University Press

(1784), 1968 Idee zu einer allgemeinen Geschichte in weltbürgerlicher Absicht, AA Bd.VIII, 15-32; Engl. tr. Idea for a universal history with a cosmopolitan purpose, in Political Writings, 1991, Cambridge, Cambridge University Press, pp. 41-53

(1788), 1968 Kritik der Praktischen Vernunft, AA Bd. V, pp.1-164; Engl. Tr. Critique of Practical Reason, In The Cambridge Edition of the Works of Immanuel Kant. Practical Philosophy, 1998, Cambridge, Cambridge University Press, pp.133273

(1790) 1968, Kritik der Urteilskraft, in AA Bd. V, pp.175-485; Engl.Trans. 2000, Critique of the Power of Judgement, in The Cambridge Edition of the Works of Immanuel Kant Cambridge, Cambridge University Press 
(1793), Über den Gemeinspruch: “Das mag in der Theorie richtig sein, taugt aber nicht für die Praxis", AA VIII 273-313, Engl. tr. On the Common Saying: "This maybe true in Theory, but it does not apply in Practice", Political Writings, 1991, Cambridge, Cambridge University Press, pp. 61-93

- (1795), Zum ewigen Frieden. Ein philosophischer Entwurf, Bd. VIII, 341-386;

Engl. tr. Perpetual Peace: a Philosophical Sketch, in Political Writings, 1991, Cambridge, Cambridge University Press, pp. 93-131

-- (1797), Metaphysik der Sitten, erster teil: Metaphysische Anfangsgründe der

Rechtslehre, Bd. VI, 203-372; Engl. tr. Metaphysics of Morals, in Political Writings, 1991, Cambridge, Cambridge University Press, pp. 131-175

Kantorowicz, E. 1957 The King's Two Bodies: a Study in Medieval Political Theology, Princeton, Princeton University Press

Kemper, P. (ed.) 1989, Macht des Mythos - Ohnmacht der Vermunft?, Frankfrut am Main, Fischer Taschenbuch Verlag

Kenny, A.J.P. 1973, Wittgenstein, London, Allen Lane, Penguin

Kerényi, K., 1941, Prolegomena, in Kerenyi, K., Jung, C.G. (1941), pp.1-25

Kerényi, K. Jung, C.G. (1941), Einführung in das Wesen der Mythologie, eng. tr.1963

Essays on a science of mythology. Princeton, Princeton University Press

Kersting, W. 1992, Politics, freedom and order: Kant's political philosophy, in Guyer, P.

(ed.) The Cambridge Companion to Kant, Cambridge, Cambridge University Press

Kirk, G.S. 1970, Myth. Its Meaning and Functions in Ancient and Other Cultures, Berkeley, University of California Press

\section{-_-1974, The Nature of Greek Myth, Hardmondsworth, Penguin}

Kirk, G.S, Raven, J.E., Schofield, M. 1983, The Presocratic Philosophers, Cambridge, Cambridge University Press

Koselleck, R. 1979, Vergangene Zukunft, Frankfurt a. M., Suhrkamp

Koyré, A. 1957, From the Closed World to the Infinite Universe, Baltimore, John Hopkins University Press

Krämer, H. J. 1982, Platone ed i fondamenti della metafisica, Milano, Vita e Pensiero 1995, Platons ungeschriebene Lehre, in Kobusch, T. und Mojsisch, B. (eds.) Platon. Seine Dialoge in der Sicht neuer Forschungen, Darmstadt, Wissenschaftliche Buchgesellschaft 
Krois, J.M. 1979, "Der Begriff des Mythos bei Ernst Cassirer", in Poser, H. (ed) 1979, Philosophie und Mythos. Ein Kolloquium, Berlin, De Gruyter, pp. 199-218

Labov, W. 1972, Language in the Inner City, Philadelphia, University of Pennsylvania Press

La Caze, M. 2002, The Analytic Imaginary, Ithaca, Cornell University Press

Landucci, S. 1972, I Filosofi e i selvaggi, Bari, Laterza

Lang, B. 1989, “The Politics Of Interpretation: Spinoza's Modernist Tum", in Review of Metaphysics, reprinted in Lloyd 2001 (ed), Vol. III, pp.293-318

Larzilliére, P. 2003, "Le «martyr » palestinien, novelle figure d'un nationalisme en échec", in Dieckhoff and Leveau 2003, pp. 89-119

Leghissa, G. 2002, "Mito, dogma e genesi del moderno in Hans Blumenberg", in H. Blumeberg 1971, Traduz. Italiana, pp. 5-35

Le Goff, J. (1980) 2000 "The Medieval West and the Indian Ocean: An Oneiric Horizon", in Padgen 2000 (ed), pp. 1-21

Lemon, L. and Reis, M. 1965 (eds) Russian Formalist Criticism: Four Essays, Lincoln, University of Nebraska Press

Lentin, A. 2004, Racism and Anti-Racism in Europe, London, Pluto Press

Levi-Strauss, C. 1958, Anthropologie structurale, Paris, Plon

------1962, La pensée sauvage, Paris, Plon 1964, Mythologiques : Le cru et le cuit, Paris, Plon 1965, Mythologiques : L'Homme nu, Paris, Plon 1978, Myth and Meaning, London, Routledge

-.--1987, Paroles données, Paris, Plon; Engl. tr. Anthropology and myth: lectures, 1951-1982, Oxford, Blackwell

Liddell, H.G., Scott, R., Stuart, J.H. 1968, A Greek-English Lexicon, Oxford, Clarendon Press

Lloyd, G. 2001 (ed) Spinoza. Critical Assessments, London, Routledge

Locke, J. (1688) 1997, An Essay Concerning Human Understanding, London, Penguin

Löwith, K. 1941, Von Hegel zu Nietzsche, Zürich, Europa Verlag 1949, Meaning in History. The Theological Implication of the Philosophy of History, Chicago, Chicago University Press

Lotito, L. 2002, "Introduzione" a Schelling. Introduzione filosofica alla filosofia della mitologia, Milano, Bompiani 
Macpherson, C.B. 1964, The Political Theory of Possessive Individualism, London, Oxford University Press

Maltese, C. 1992, Storia dell'arte in Italia 1785-1943, Torino, Einaudi

Malinowski, (1926) "Myth in Primitive Psychology", in Malinowski 1948, pp.94-147 (1948) 1992 Magic, Science and Religion and Other Essays by Bronislaw Malinowski, Illinois, Waveland Press

Mannheim, K. (1936) 1960, Ideology and Utopia, London, Routledge and Kegan Paul Marcuse, H. (1964) 1991, One Dimensional Man: Studies in the Ideology of Advanced Society, Boston, Beacon Press

-.-.- (1967) 1980, Das Ende der Utopie, Berlin, Verlag Neue Kritik

Martin, L.H; Gutman, H. and Hutton, P. (eds) 1988 Technologies of the Self. A Seminar with Michel Foucault, The University of Massachusetts Press

Marx, K. (1844) 1982 Zur Kritik der Hegelschen Rechtphilosophie. Einleitung, in Karl Marx Friderich Engels Gesamtausgabe (MEGA), Bd. I-2, Berlin, Dietz Verlag (1852) 1978, "Der achtzehnte Brumaire des Louis Bonaparte", in Marx Engels Werke, Berlin, Dietz Verlag, Bd. VIII, pp. 11-194 Eng. Trans. 1969 "The Eighteenth Brumaire of Luis Bonaparte", In Karl Marx and Frederick Engels. Selected Works in Three Volumes, Moscow, Progress Publisher

Marx, K. and Engels, F. (1845-46)1978, Die deutsche Ideologie, in Marx Engels Werke, Berlin, Dietz Verlag, Bd. III

Martin, R.P. 1989, The Language of Heroes: Speech and Performance in the Iliad, Ithaca, Comell University Press

Marquard, O. 1979, "Lob des Polytheismus: Über Monomythie und Polymythie", in Poser (ed) 1979, pp. $40-59$

McCormick, J.P. 1997, Carl Schmitt's Critique of Liberalism. Against Politics as Technology, Cambridge, Cambridge University Press

Mead, G. H. 1934, Mind, Self and Society, Chicago, Chicago University Press

Meier, C. 1980, Die Entstehung des Politischen bei den Griechen, Frankfurt am Main, Surkamp; Eng. Trans. 1990, The Greek Discovery of Politics, Cambridge, Mass. Harvard University Press

Melucci, A. 2000 “Costruzione di sé, narrazione, riconoscimento" in Della Porta, Greco, Szakolczai (eds) 2000 , pp. 30-45

Messeri, M. 1997, Verità, Firenze, La Nuova Italia 
Midgley, M. 2003, The Myths We Live By, London, Routledge

Moeller, J. 1988 "Nature, Human Nature, and Society in the American Western", in Yanarella and Siegelman (eds.) 1988

Moore, S.F. 1975 "Epilogue" in Moore S.F. and Meyerhoff, B. (eds) Symbol and Politics in Communal Ideology, Comell University Press Ithaca, Ithaca, N.Y.

Moravcsik, J. 1992, Plato and Platonism. Plato's Conception of Appearance and Reality in Ontology, Epistemology, and Ethics, and its Modern Echoes, London, Blackwell

Moreau, P.-F. 1994, Spinoza: L'expérience et l'étemité, Paris, PUF

Morgan, K. 2000, Myth and Philosophy from Presocratics to Plato, Cambridge, Cambridge University Press

Mosse, G.L, 1974, The Nationalization of Masses. Political Symbolism and the Mass movements in Germany from Napoleonic Wars through the Third Reich, New York, Howard Ferting

Nestlé, W. 1942, Vom Mythos zum Logos: die Selbstentfaltung des grieschischen Denkends von Homer bis auf die Sophistik und Sokrates, Stuttgart, A. Kröner

Neumann, K. 1972, "Idee", in Gabriel, G., Gründer, K., Ritter, J. (eds.) Historisches Wörterbuch der Philosophie, Bd. VII, Darmstadt, Wissenschaftliche Buchgesellschaft, pp. 55-134

Nietzsche, F. (1872) 1973, Die Geburt der Tragödie, oder: Griechentum und Pessimismus, in Nietzsche Werke, Kritische Gesamtausgabe, Colli, G. \& Montinari, M.(eds), Berlin, De Gruyter

-(1885) 1973, Jenseits von Gut und Böse, in Nietzsche Werke, Kritische Gesamtausgabe, Colli, G. \& Montinari, M. (eds), Berlin, De Gruyter - (1887) 1973-, Zur Genealogie der Moral. Eine Streitschrift, in Nietzsche Werke, Kritische Gesamtausgabe, Colli, G. \& Montinari, M.(eds), Berlin, De Gruyter -- 1984, Nietzsche Briefwechsel. Kristische Gesamtausgabe, Colli, G. \& Montinari, M. (eds), Berlin, De Gruyter

Nussbaum, M. (1986) 2001 The Fragility of Goodness. Luck and Ethics in Greek Tragedy and Philosophy, Cambridge, Cambridge University Press

-.-.-- 2001, Upheavals of Thought: The Intelligence of Emotions, Cambridge, Cambridge University Press

Olson, D.R., Torrance N. (eds.) 1991, Literacy and Orality, Cambridge, Cambridge University Press 
Onions, C.T. 1966, The Oxford Dictionary of English Etymology, Oxford, Clarendon Press Pagden, A. 2000 (ed) Facing Each Other. The World's Perception of Europe and Europe's Perception of the World, Aldershot, Ashgate

Paggi, L. 1999 (ed) Le memorie della Repubblica, Firenze, La Nuova Italia

Panikkar, R. 1962, "La demitologizzazione nell'incontro tra Cristianesimo e Induismo", in Il Problema della demitizzazione. Atti del convegno indetto dal Centro Internazionale di Studi Umanistici e dall'Istituto di Studi Filosofici, Roma, Archivio di Filosofia

-....- 1964, The Unknown Christ of Hinduism, London, Darton, Longman and Todd

Passerini, L. 1998, (ed), Identità culturale europea, Firenze, La Nuova Italia 2003 (ed) Figures d'Europe. Images and Myths of Europe, Brussels, P.I.E.- Peter Lang

----- 2003 "Dimensions of the Symbolic in the Construction of Europeanness" in Passerini (ed) 2003, pp. 21-35

Pavone, C. 1991 Una Guerra civile. Saggio storico sulla moralità nella resistenza, Torino, Bollati Boringhieri

1995, Alle origini della repubblica: Scritti su fascismo, antifascismo e continuità dello stato, Torino, Bollati Boringhieri

Pellegrin, P. 2001, Le Vocabulaire d'Aristote, Paris, Ellipses

Pieper, J. 1965, Über die platonischen Mythen, München, Kösel Verlag

Pizzomo, A. 1993, Le radici della politica assoluta e altri saggi, Milano, Feltrinelli

-...- 2000 "Risposte e proposte", in Della Porta, Greco, Szakolczai (2000) eds, pp.197246

Plato, [1900-1907], Platonis Opera, Oxford, Oxford University Pres, Scriptorum Classicorum Bibliotheca Oxoniensis; Engl. tr. Hamilton, E., Cairns, H. (eds.) (1989) The Collected Dialogues of Plato including the letters, New Haven, Princeton University Press

Poser, H. (ed) 1979, Philosophie und Mythos. Ein Kolloquium, Berlin, De Gruyter

Preus, S. 1989 "Spinoza, Vico, and the Imagination of Religion", in Joumal of The Histories of Ideas, 50, pp.71-93

Rath, I.W. 1992, Die verkannte mythische Vernunft. Perspektiven einer vernünftigen Alternative, Wien, Passagen Verlag

Rawls, J. 1971, A Theory of Justice, Oxford, Oxford University Press 
-.----1993, Political Liberalism, New York, Columbia University Press

Reale, G. 1986, Per una nuova interpretazione di Platone. Rilettura dei grandi dialoghi alla luce delle dottrine non scritte, Milano, Vita e Pensiero

-.--1991, Platone. Tutti gli scritti, Milano, Rusconi

Ricoeur, P. 1965, De l'interprétation: Essai sur Freud, Paris, Seuil

1994, "Imagination in discourse and in action" in Robinson, G., Rundell, J., Rethinking Imagination: Culture and Creativity, London, Routledge, pp. 118-135

Robb, K. (ed.) 1983, Language and Thought in Early Greek Philosophy, La Salle, Hegeler Institute

Rorty, R. 1989, Contingency, Irony, and Solidarity, Cambridge, Cambridge University Press

Rosenberg, A. (1930), 1941, Der Mythus des 20. Jahrhunderts - Eine Wertung der seelisch-geistigen Gestaltenkämpfe unserer Zeit, München, Hoheneichen-Verlah

Rosenthal, M. (1997), 2001 "Why Spinoza Chose the Hebrews: The Exemplary Function o Prophecy in the Theological-Political Treatise", In History of Political Thought 18, reprinted in Lloyd (ed) 2001, Vol. III, pp.245-281

Ross, W.D. 1951, Plato's theory of ideas, Oxford, Clarendon Press

Rousseau, J. J. (1754), 1996 Discours sur l'origine et les Fondements de l'inégalité parmi les hommes, Paris, Librairie Générale Française

-..--..- (1762), 2001, Du Contract Social, Paris, Flammarion

Rundell, J. 1994a, "Introduction" in Robinson, G., Rundell, J., 1994, Rethinking Imagination: Culture and Creativity, London, Routledge, pp. 1-11

Rundell, J. 1994b, "Creativity and judgement: Kant on reason and imagination" in Robinson, G., Rundell, J., 1994, Rethinking Imagination: Culture and Creativity, London, Routledge, pp. 87-117

Russell, B. 1922, "Introduction", in Wittgenstein, L., Tractatus Logico-Philosophicus, London, Routledge

Sabbatucci, D. 1978, Il mito, il rito e la storia, Roma, Bulzoni Editore

Schelling, F.W.J. [1856-1861] Philosophische Einleitung in die Philosophie der Mythologie oder Darstellung der reinrationalen Philosophie, in F.W.J. Schellings Sämmtliche Werke, Stuttgart, Cotta, Bd. XI

Scheman, N. 1996, "Forms of life: Mapping the Rough Ground" in Sluga and Stern (eds.) 1996 
Schlegel, F.S., Schlegel, A.W. (1798-1800) 1992, Athenäum. Eine Zeitschrift von A.W.

Schlegel und F.S. Schlegel, Darmstadt, Wissenschaftliche Buchgesellschaft

Schlüchter, W. 1979, Die Entwicklung des okzidentalen Rationalismus, Tübingen, J.C.B.

Mohr

Schneider, H.J. 1999, „Creation and recreation: The Interplay of Activity and Structure in language", in Joumal of Pragmatics, 31, pp. 669-684

Schmitt, C. (1922) Politische Theologie, Berlin, Dunker und Humblot; Engl. trans. Political Theology, Cambridge Mass., MIT Press

--..-- (1923) 1988, "Die politische Theorie des Mythus", in Positionen und Begriffe im Kampf mit Weimar-Genf-Versailles, Berlin, Dunker und Humblot

------ $\left(1923^{1} 1926^{2}\right)$ Die geistesgeschichtliche Lage des heutigen Parlamentarismus, Berlin, Dunker und Humblot; Engl. trans. 1985 The Crisis of Parliamentary Democracy, Cambridge Mass., MIT Press

Shevory, T.C. 1988, "Winning Isn't Evrything: Sport Fiction as a Genre of Political Criticism" in Yanarella and Siegelman 1988 (eds)

Shils, E. 1958 "Ideology and Civility: On the Politics of the Intellectual", in The Sawanee Review, 66, pp.450-480

Simpson, J.A., Weiner, E.S.C. (eds.) 1989, The Oxford English Dictionary, Oxford, Clarendon Press

Sluga, H. and Stern, D. (eds) 1996, The Cambridge Companion to Wittgenstein, Cambridge, Cambridge University Press

Smelser, N.J and Baltes, P.B. 2001 (eds), International Encyclopedia of The Social \& Behavioural Sciences, Amsterdam, Elsevier

Smith, A.D. 1986, The Ethnic Origins of Nations, Oxford, Blackwell 1991, National Identity, London, Penguin 1999, Myths and Memories of the Nation, London, Routledge

Sorel, G. $\left(1908^{1}-1950^{\prime \prime}\right)$ 1990, Réflexions sur la violence, Paris, Seuil

Spinoza, B. (1670) Tractatus theologicus-politicus, Engl. tr. Elwes, R.H.M. [1951], A Theologico-Political Treatise and a Political Treatise, New York, Dover Publications, pp. 1-266

- [1951], Tractatus Politicus, Engl. tr. Elwes, R.H.M. [1951], A Theologico-Political Treatise and a Political Treatise, New York, Dover Publications, pp. 267-387 
[1985] Ethica, Engl. tr. Curley, E. (ed.) The Collected Works of Spinoza,

Princeton, Princeton University Press; Vol. I, pp. 401-617

Stoppino, M. 1983 "Ideologia" in Bobbio, Matteucci, Pasquino (eds) 1983

Stråth, B. (ed.) 2000, Myth and Memory in the Construction of the Community, Brussels, Peter Lang

-...... "Introduction. Myth, Memory and History in the Construction of Community" in Stråth 2000, pp.19-49

Taylor, C., 1985a, Human Agency and Language, Cambridge, Cambridge University Press 1985b, Philosophy and the Human Sciences, Cambridge, Cambridge University Press

-1989, Sources of the Self. The making of Modern Identity, Cambridge, Cambridge University Press

-- 1991, The Malaise of Modemity, Cambridge (MA), Harvard University Press -1 1992, The Politics of Recognition, New Haven, Princeton University Press 1994, Multiculturalism and the Politics of Recognition, Princeton, Princeton University Press

--_--- 1995, Philosophical Arguments, Cambridge (MA), Harvard University Press

-.----2 2003, "Ethics and ontology" in Jourmal of Philosophy, 6, pp. 305-320

Tebben, J.R. 1994, Concordantia Homerica. Pars I Odissea, Hildesheim, Olms-Weidmann

------ 1998, Concordantia Homerica. Pars II llias, Hildesheim, Olms-Weidmann

Terrier, J. 2002, "Culture et types de l'action sociale", Revue européenne des sciences sociales, 122, pp.141-153

Thomas Aquinas, Saint [1975] Summa theologiae. English and Latin, edited and translated by J. Cunningham, London, Blackfriars

Thomas, R. 1992, Literacy and Orality in Ancient Greece, Cambridge, Cambridge University Press

Thompson, J.B. 2001, "Ideology: History of the Concept", in Smelser and Baltes (eds) 2001, Volume 11, pp7170-7174

Thorsen, A. 2000 "Foundation Myth at Work: National Day Celebrations in France, Germany and Norway in a Comparative Perspective" in Stråth (ed) 2000, pp. 331351

Thucydides, [1919], History of the Peloponnesian War, Engl. tr. by C.F. Smith, London, Heinemann, Loeb Classical Library, 4 Vol. 
Tomashevski, B. (1925) 1965, “Thematics", in Lemon and Reis 1965, pp.61-95

Toolan, M.J. 1988, Narrative. A Critical Linguistic Introduction, London, Routledge

Tudor, H. 1972, Political Myth, London, Macmillan

Vattimo, A. 1999a, "Estetica", in Enciclopedia di filosofia, AA.VV, Milano, Garzanti, pp. 340-345

1999b, "Immaginazione", in Enciclopedia di filosofia, AA.VV, Milano, Garzanti, pp. 528-530

Vernant, J.-P. (1965), 1990, Mythe et pensée chez les grecs. Etudes de psychologie Historique, Paris, La Découverte

Veyne, P. 1983, Les Grecs ont-ils cru à leurs mythes ?, Paris, Engl. tr. 1988, Did Greeks believe in their myths?, Chicago, University of Chicago Press

Vico, G. (1744) 1992, Principi di scienza nuova, Milano, Mondadori

Vlastos, G. 1965, "Degrees of Reality in Plato", in Bambrough, R. (ed), New Essays on Plato and Aristotle, London, Routledge

Volkmann-Schluck, K.-H. 1969, Mythos und Logos. Interpretationen zu Schellings Philosophie der Mythologie, Berlin, De Gruyter

Von Savigny, E. 1991, "Common Behavior of Many A Kind", in Arrington and Glock (eds) 1991, pp. 105-119

Yanarella, E.J. and Siegelman (eds) 1988, Political Mythology and Popular Fiction, New York, Greenwood Press

Young, R 1990, White Mythologies. Writing History and the West, London, Routledge

Wagner, P. 1994, A Sociology of Modemity, London, Routledge 2002, "Identity and Selfhood as a Problematique" in Friese (ed) 2002, pp. $32-56$ 2004, "Palomar's question. The axial age hypothesis. European Modernity and historical contingency", in Arnason, Eisenstadt, Wittrock (eds) 2004

Wallace, R. 1984, "Introduction to Blumenberg", in New German Critique, 32, pp. 93-108

Walzer, M. 1964, "On the role of symbolism in political thought", in Political Science Quarterly, 82, June, pp. 120-203

Warrender, H. 1957, The political philosophy of Thomas Hobbes, Oxford, Clarendon

Wartelle, A. 1982, Lexique de la «Rhétorique» d'Aristote, Paris, Les Belles Lettres

Weber, M. (1905) 1920 Die protestantische Ethik und der Geist des Kapitalismus, in 1984Max Weber Gesamtausgabe, edited by $\mathrm{H}$. Baier et alii, Tübingen Mohr; eng. Trans. 1976, The Protestant Ethic and the Spirit of Capitalism, London, Allen and Unwin 
-..- (1919a) Wissenschaft als Beruf, in Max Weber Gesamtausgabe, Abteilung I, Bd. XVII, pp.49-112

-- (1919b) Politik als Beruf, in Max Weber Gesamtausgabe, Abteilung I, Bd. XVII, pp. 113-157

- (1922) Wirtschaft und Gesellschaft, in Max Weber Gesamtausgabe, Abteilung I, Bd. XXII 1-XXII 5

-- [1969] On Charisma and Institution Building, edited by S. Eisenstadt, Chicago, Chicago University Press

White, H. 1987, The content of the form. Narrative Discourse and Historical Representation, Baltimore, The John Hopkins University Press

2000 "Catastrophe, Communal Memory and Mythic Discourse: The Uses of Myth in the Reconstruction of Society", in Stråth 2000 (ed), pp.49-75

Whitebook, J. 1989, "Intersubjectivity and the Monadic Core of the Psyche: Habermas and Castoriadis on the Unconscious", in AAVV 1989, Autonomie et autotrasnformation de la société. La philosophie militante de Comelius Castoriadis, Genève, Libraire Droz, pp. 225-245

Wingo, A. H. 2003 Veil Politics in Liberal Democratic States, Cambridge, Cambridge University Press

Wittgenstein, L. $\left(1918^{1}, 1921^{2}\right)$, Tractatus logico-philosophicus, in 1995, Werkausgabe, Frankfurt a. M., Suhrkamp, Bd. I, pp. 7-87; Engl. tr. Tractatus logico-philosophicus, London, Routledge (1953) Philosophische Untersuchungen, in Werkausgabe, 1995, Frankfurt a. M. ,

Suhrkamp, Bd. I, pp. 225-581; Engl. tr. Philosophical Investigations, Oxford, Blackwell

-- 1967a, Zettel, Oxford, Blackwell 1967b, Bemerkungen über Frazer's Golden Bough; Engl. tr. 1979, Remarks on

Frazer's Golden Bough, Rhees, R., Retford, Brynmill; French Translation Ludwig Wittgenstein. Remarques sur le Rameau d'Or de Frazer, Editions l'Age d'Homme -.-.-1969, On Certainty, Oxford, Blackwell

Wolin, R. 1990, "Carl Schmitt, political existentialism and the total state", in Theory and Society, 19, pp.389-416 




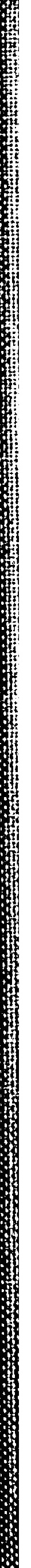


